F $2 i$

1980

An Inventory of Vegetation, WildLife and Recreational Resources of the Long Pines, Montana

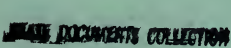

NOV 171980

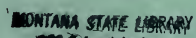

Ho to Lindute Ave.

FINAL REPORT

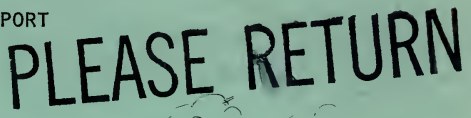

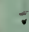

,

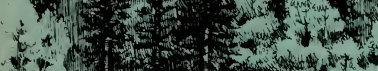

intive
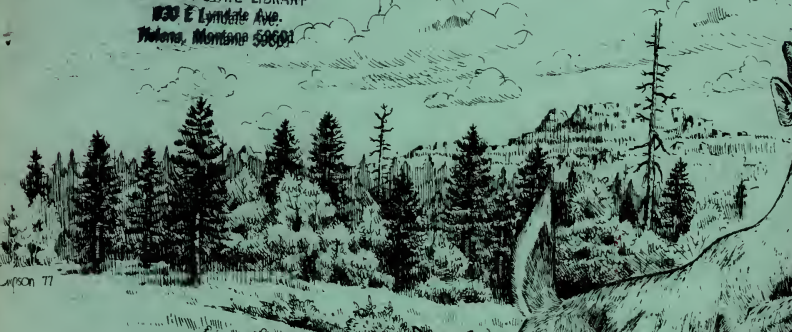

Research conducted by Montana Department of Fish, Wildlife \& Parks ECological Services Division

Sponsored by U. S. Fish \& WildLife Service OFFICE OF BIOLOGICAL SERVICES

BY:

GARY L. DUSEK OCTOBER 1980 
MST, JAN $28^{\prime} 81$

\section{ब9S2 9148}

OCT 241984

$\operatorname{Dec} 12 \cdot 84$

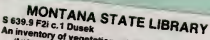

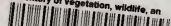

IIIII II I II IIIIII:

30864000353923

1

,

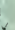




\section{ACKNOWLEDGMENT}

We would like to express our appreciation to Larry Thompson of the Montana Department of Naturat Resources \& Conservation, Helena, Montana, for the original drawing on the cover of this publication. 

TABLE OF CONTENTS

Page

List of Tables.

List of Fingures.

Introduction.

Study Area.

Physiography

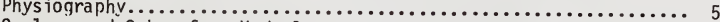

Geology and Subsurface Hydrology........................ 5

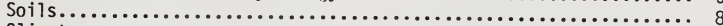

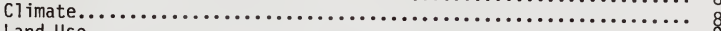

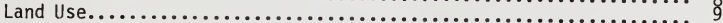

Part I - Description of Vegetational Communities ................. 13

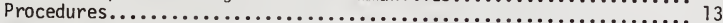

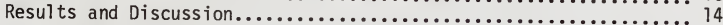

Ponderosa Pine-Xeric Grassland/Shrub.......................... 14

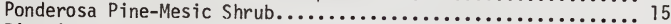

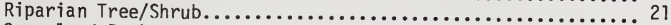

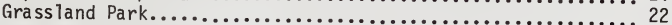

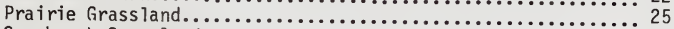

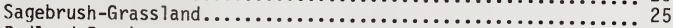

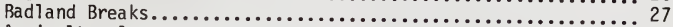

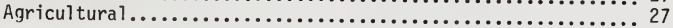

Part II - Wildlife Surveys and Inventories..................... 30

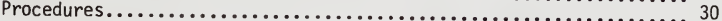

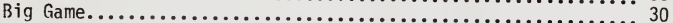

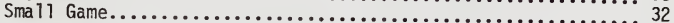

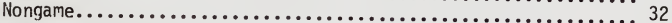

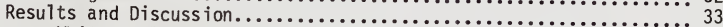

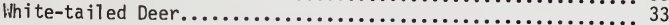

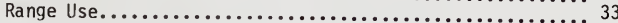

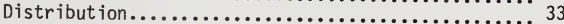

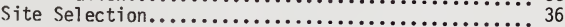

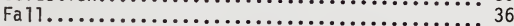

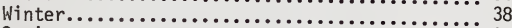

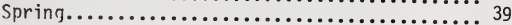

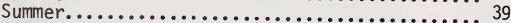

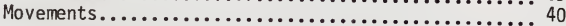

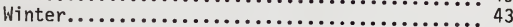

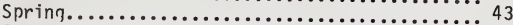

Summer.................................. 47

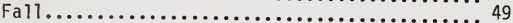

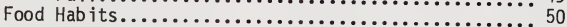

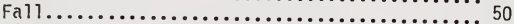

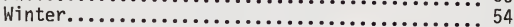

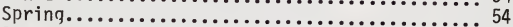

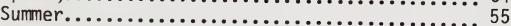

Population Characteristics................................ 55

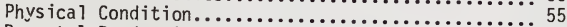

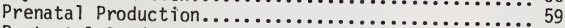

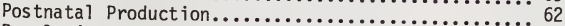

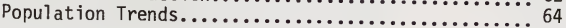


Page

Mule Deer................................... 71

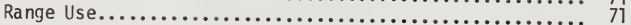

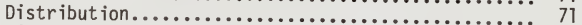

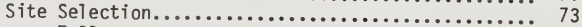

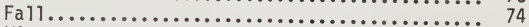

Winter................................. 74

Spring................................. 74

Summer..................................... 76

Food Habits................................ 77

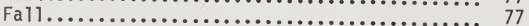

Winter..................................... 80

Spring ...................................... 80

Summer.................................. 80

Population Characteristics................................. 80

Physical Condition................................ 80

Prenatal Production................................. 83

Postnatal Production............................. 84

Population Trends........................... 86

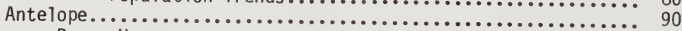

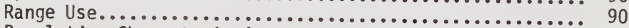

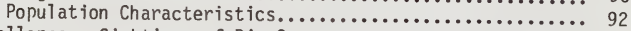

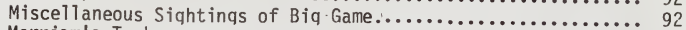

Merriam's Turkey.................................. 92

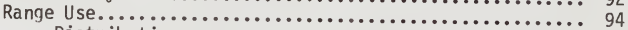

Distribution...................................... 94

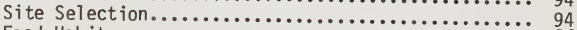

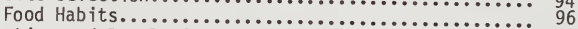

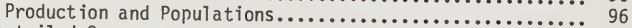

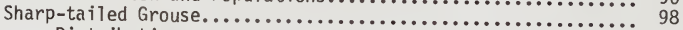

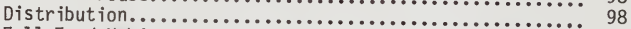

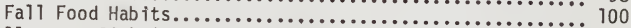

Miscellaneous Sightings of Small Game....................... 100

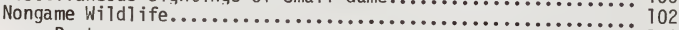

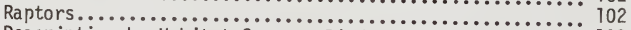

Description by Habitat Group - Birds.................... 109

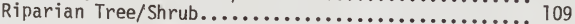

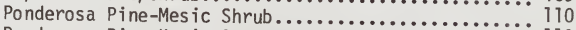

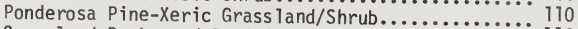

Grassland Parks and Prairie Grasslands.................. 110

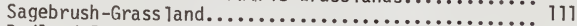

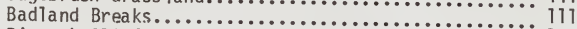

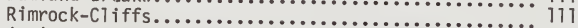

Description by Habitat Group - Mammai

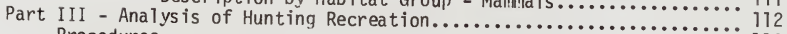

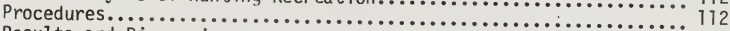

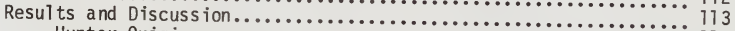

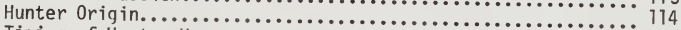

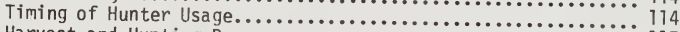

Harvest and Hunting Pressure........................................... 117

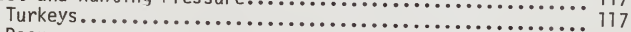

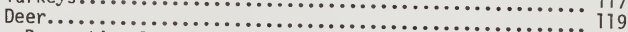

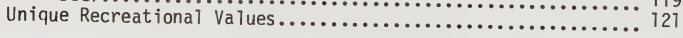


Part IV - Implications of Uranium Development.................. 124

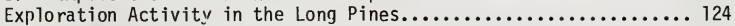

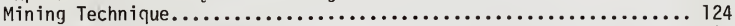

Environmental Considerations............................... 125

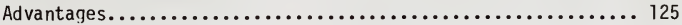

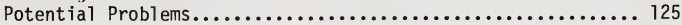

Part V - Conclusions and Recommendations....................... 128

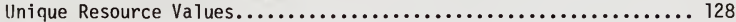

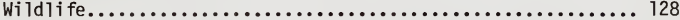

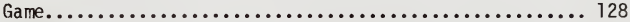

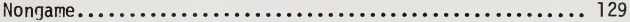

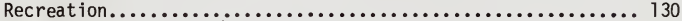

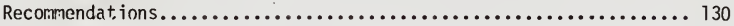

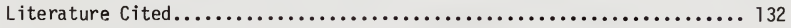

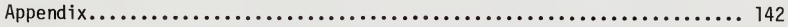




\section{LIST OF TABLES}

Table

Page

1. Seasonal departures from normal precipitation and temperatures from September 1976 through August 1979 as derived from monthly data compared to a 30-year average (1941-1970) for Ekalaka, Montana a

2. Diagnostic vegetation of habitat groups in the Long Pines study area as determined from analys is of $9602 \times 5$ decimeter plots among 48

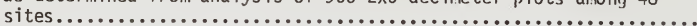

3. Seasonal and annual use of habitat groups by white-tailed deer in the Long Pines study area as determined from routine vehicle

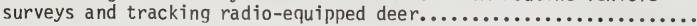

4. Seasonal and annual distribution of white-tailed deer among four classes of gradient as determined from vehicle route surveys.......

5. Seasonal and annual distribution of white-tailed deer among level ridgetops, drainage bottoms and four exposures as determined from

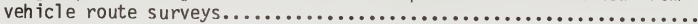

6. Annual and seasonal home ranges of 13 white-tailed deer equipped with radio transmitters whose movements were monitored for at least one

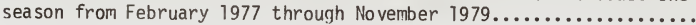

7. Seasonal mean consecutive distances and maximum distances travelled among 13 white-tailed deer equipped with radio transmitters........

8. Semi-seasonal food habits of white-tailed deer in the Long Pines as determined from analysis of 105 rumen samples from 0ctober 1976 through November 1979 .

9. Whole and field-dressed weights of 23 white-tailed deer collected in the Long Pines from December 1976 through March 1978 and departures, by age and sex class from state-wide averages.........

10. Seasonal kidney fat indices of white-tailed deer by sex and age class as determined from 71 specimens obtained from December 1976 through November 1979

11. Prenatal productivity of white-tailed deer determined from analysis of reproductive tracts of 28 females taken during December-May 1976-77 and 1977-78 and during January 1979.

12. Population structure of white-tailed deer in the Long Pines study area from late summer through spring as determined from

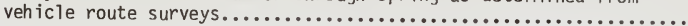

13. The proportion of females $1 \frac{1}{2}$ years and older that were accompanied by 0,1 or 2 fawns during fall of 1976-79. 
Table

Page

14. A model of population size, composition and turnover of whitetailed deer in the Long Pines from fall 1977 through early winter 1978-79.

15. Composition by sex and age of 123 white-tailed deer trapped in the Long Pines during the winters of 1976-77, 1977-78 and 1978-79......

16. Composition by sex and age of white-tailed deer taken by hunters in the Long Pines from 1976-79 from animals checked in the field and from questionnaires.

17. Composition by sex and age of 34 of white-tailed deer that died during late winter and early spring 1978 and composition by age among 51 that died during that period among all years..............

18. Seasonal and annual use of habitat groups by mule deer in the Long Pines study area as determined from both ground and aerial surveys.

19. Seasonal and annual distribution of mule deer among four classes of gradient as determined from aerial and ground surveys..............

20. Seasonal and annual distribution of mule deer among level ridgetops, drainage bottoms and four exposures as determined from aerial and ground observations.

21. Habitat use by mule deer among three subunits of the Long Pines study area during early winter 1977-78 and 1978-79 combined as determined from intensive aerial surveys.

22. Semi-seasonal food habits of mule deer in the Long Pines as determined from analysis of 37 rumen samples from 1976-79a.

23. Seasonal kidney fat indices of mule deer by sex and age class as determined from 29 specimens obtained from June 1978 through November 1979

24. Population structure of mule deer in the Long Pines study area from late summer through spring as observed from aerial and ground surveys.85

25. The proportion of single or pairs of female mule deer $1 \frac{1}{2}$ years and older that were accompanied by zero, 1 or 2 fawns during fal1 1977-79.

26. A model of population size, composition and turnover of mule deer

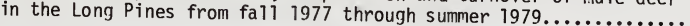

27. Population numbers and composition of antelope in the Long Pines study area as determined from aerial surveys during July 1977-78 and August 1979 
Table

28. Fall foods of Merriam's turkeys in the Long Pines from 1976-79 as determined from analys is of crop contents of 17 hunter-killed birds.

29. Fall foods of sharp-tailed grouse in the Long Pines study area during 1976-79 as determined from analysis of crop contents of 14 hunter-killed birds.

30. Status, abundance and habitat use of the nongame birds in the Long Pines (Nomenclature follows the A.0.V. checklist (1957) and

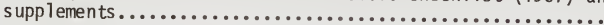

31. Abundance and habitat occurrence (when known) of nongame mammals

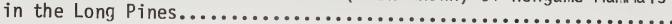

32. Origin of 369 hunters from 122 parties responding to questionnaires distributed during fal1 hunting seasons of $1976-79 \ldots \ldots \ldots \ldots \ldots . .114$

33. Hunter use during 3 periods of the hunting season by resident and nonresident hunters as determined from questionnaires from 197679

34. Yearly trends in traffic indices during 3 periods of the hunting season from 1976-78.

35. Fall turkey harvest for the Long Pines from 1976-79 and for all of Carter County from 1975-78 as determined from questionnaires...... 118

36. Hunting pressure and effort expended per animal harvested for deer and turkeys in the Long Pines from 1976-79

37. Deer harvest for the Long Pines from 1976-79 and for hunting district 781 from $1975-78$ as determined from questionnaires....... 120

38. Reasons offered by respondents to the questionnaire as to why they chose to hunt in the Long Pines (1978-79).

39. The potential effect of mineral development on attitudes of hunters towards hunting in the Long Pines (1978-79)..............123

Appendix Tables

1. Climatological data from September 1976 through August 1979 for

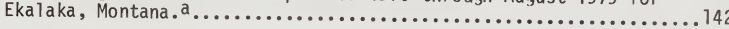

2. Climatological data from September 1976 through August 1979 for Camp

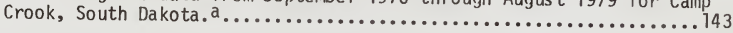

3. Constancy and frequency of low-growing vegetation on 4 vegetational communities with an overstory of trees and/or shrubs as determined from examination of $202 \times 5$ decimeter plots on each of 26 sites.... 144 
4. Constancy and frequency of low-growing vegetation on 5 vegetational communities in the grassland/badland complex of Long Pines study area as determined from examination of

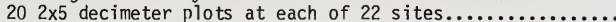

5. Seasonal and annual distribution by time of day of white-tailed deer observed from vehicle surveys and relocations of radioed

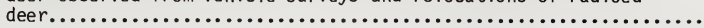




\section{LIST OF FIGURES}

Figure

Page

1. The Long Pines study area, Carter County, Montana............ 4

2. Elevational relief and outcropping of geological strata in the

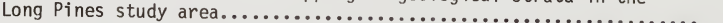

3. Mean monthly precipitation and temperatures for Ekalaka, Montana

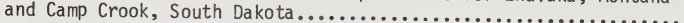

4. Ponderosa pine-xeric grassland/shrub habitat group in the north end of the study area (top) and along the south edge............. 16

5. Ponderosa pine-mesic shrub habitat group................. 17

6. Changes in frequency of 6 taxa on ponderosa pine-mesic shrub sites

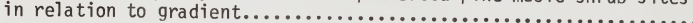

7. Riparian tree/shrub habitat group (Fraxinus pennsylvanicus/Acer

8. Grassland parks and prairie grasslands.................... 24

9. Frequency of 6 key species on grassland parks and prairie grasslands in relation to slope and exposure.......................... 26

10. Sagebrush-grassland habitat group: Artemista tridentata/Agropyron h.t.; and Artemisia cana/Agropyron smithii h.t............... 28

11. Badland breaks habitat group and agricultural group............ 29

12. Distribution of white-tailed deer in the Long Pines study area.... 35

13. Distribution by season of sightings among 38 individual1y marked (collared) white-tailed deer from February 1977 through August 1979.

14. Annual home range and seasonal distribution of a radio-equipped adult female white-tailed deer (1769) from December 1977 through November 1979

15. Annual home range and seasonal distribution of 2 adult female and 2 adult male white-tailed deer equipped with radio transmitters in the Long Pines study area.

16. Seasonal use of forage classes by white-tailed deer in the Long Pines study area.

17. Semi-seasonal trends in physical condition of white-tailed deer in the Long Pines study area determined from kidney fat indices from December 1976 - November 1979 
Figure

18. Distribution of mule deer in the Long Pines study area......... 72

19. Seasonal use of forage classes by mule deer in the Long Pines

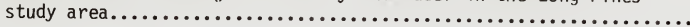

20. Semi-seasonal trends in physical condition of mule deer in the Long Pines study area determined from kidney fat indices from June 1978 - November 1979

21. Summer distribution of antelope in the Long Pines study area...... 91

22. Distribution of turkeys in the Long Pines study area.......... 95

23. Location of sharp-tailed grouse dancing grounds and winter concentrations in the Long Pines study area.................. 99

24. Weekly trends in traffic use in the Long Pines during the fall

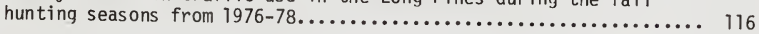

Appendix Figure

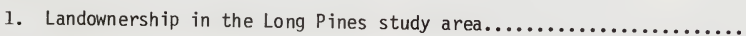

2. Distribution of vegetational cover in the Long Pines study area from

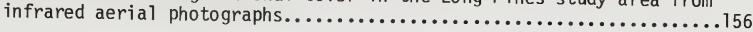





\section{INTRODUCTION}

The energy producing potential of the western United States has received nationa1, as well as regional interest during the 1970's. This interest has been focused primarily on development of coal reserves in the Fort Union and Powder River regions which include eastern Montana as we 11 as western North Dakota and northeastern Wyoming. However, the western energy boom has also included prospecting and assessment work to locate uranium ore that can be "economically" mined. Since the early 1970's such activity in Montana has intensified in the extreme southeast corner of the state. Of particular concern to our agency is a 66,000 acre $\left(267 \mathrm{~km}^{2}\right)$ tract of national forest lands known as the Long Pines in the Sioux District of the Custer National Forest. In the past the only potentially important occurrences of uranium in the region were associated with lignite beds in the Fort Union Formation (Jarrard 1957), but more recent exploration has indicated that more valuable uranium ore may occur in older sedimentary deposits underlying this formation. The environmental statement and manaqement plan for the Sioux District precluded surface mining in the district (U.S. Forest Service 1976b) partially due to depths of uranium bearing strata. However, this administrative decision does not apply to adjoining private and state lands which could still be subjected to surface mining. Solution or "in-situ" mining has been suggested as an alternative to underground or surface mining.

Development of uranium, by whatever means, offers an array of problems that threaten wildilife and associated recreational activities. Some problems arise from the antiquated Mining Act of 1872, which along with more recent authoritative decisions, comprise present U.S. mining law (Stout 1961). Unlike coal, which is a leasable mineral, uranium is classified as a locatable mineral on most public lands. An exception includes lands acquired by purchase from states or private individuals by the U.S. government (i.e., Bankhead-Jones Act) where uranium is also a leasable mineral (U.S. Fish and Wildlife Service 1977). Locatable minerals are regulated by federal mining laws. Regulations covering locatable minerals provide little if any environmental protection as opposed to those covering leasable minerals. Lands open to mineral location include all federal lands with the exception of national parks and monuments and lands acquired under the Bankhead-Jones Act. Withdrawal of lands from mineral location can be done only at the discretion of the Secretary of the Interior. As provided under the 1872 U.S. mining law, a claimant upon proof of a valid discovery, can obtain a patent by paying a nominal price per acre, giving him all surface rights to the land. Reduction of public land to private ownership in this manner could seriously reduce the quality and quantity of public recreation the area presently offers as well as serving to impede management of wildlife habitat in the Long Pines unit.

Other problems are associated with actual development. If in-situ procedures are used, surface disturbance would likely be minimal (Allen 1979). However, siting of associated mining and milling facilities and 
increased human activity are potentially negative particularly if such sites are critical habitat for one or more species of wildlife. Even during exploration activities there is a high potential for cross contamination of water between aquifers unless well holes are properly plugged (Robbins 1979). There is also the potential for radiation contamination associated with prospecting for, mining and milling uranium (Terral 1979).

A synopsis of uranium exploration in the Long Pines and vicinity was prepared by Allen (1979). Low grade uranium ore deposits were discovered in the Will iston Basin during the late 1940's and early 1950 's. This early work suggested a potential for commercial mining of uranium in the Long Pines. A regional study by Mobil Oil Corporation (Mobil) during the late 1960's and early 1970's indicated that such deposits may occur in deeper strata. Mobil's "Fox Hills Project" was initiated in 1972 with activity directed towards locating "rollfront" type deposits in the Fox Hills Formation (Stellingwerf 1975). The project was regulated by both state and federal laws and regulations. Mobil staked 1,831 claims in the Long Pines and immediate vicinity during 1972 and drilled 10 exploratory holes (Allen 1979). By 1977, 350 holes had been drilled. Since no assessment work was carried out during 1978, Mobil's claims are now null and void and can be picked up by another prospector. Other companies staking claims either on or adjacent to the national forest prior to initiation of this study included Transcontinental 0i1 Company and Felmont 0il Company. Neither conducted any assessment work during the past three years. During 1979, Energy Reserves Group, Inc. and Rocky Mountain Energy Company applied for state prospecting permits for uranium on private lands along the southern edge of the Long Pines.

The Montana Department of Fish, Wildlife, and Parks (DFWP) became involved in the review process as early as 1973 under the authority of the Montana Strip Mining and Reclamation Act. Both leasable and locatable minerals are covered by this state law. It seemed likely that the Long Pines, in whole or in part, might qualify as an area described in Section 9 of the law which deals with denying a permit to mine based on "special, exceptional, critical or unique characteristics." During this time a lack of baseline wildlife data precluded identification and quantification of such values. A study, focusing on the ecology and life history of Merriam's turkey (Meleagris galopavo merriami) during the early 1960's (Jonas 1966), exemplified the importance of the Long Pines as a wildlife producing area. Similar data for other game species, as well as nongame species, were not available. Population trends and hunter harvest statistics gathered by the DFWP provided data for geographical units such as hunting districts or counties and not by specific ecological units. The U.S. Forest Service's environmental review process for the Sioux District (U.S. Forest Service 1976a) evaluated wildlife resources from a review of literature and from data in the district other than the Long Pines. The value of such information is superficial at best and does not identify key wildlife areas in the Long Pines. The fundamental objective of the DFWP was to gather data that will help preserve wildlife values in the Long Pines while avoiding 
a basic confrontation between federal law which grants the right to mine and the state's discretion to deny mining.

This study was conducted by the Ecological Services Division of the DFWP under a contract with the U.S. Fish and Wildlife Service (USFWS) through the Office of Biological Services (OBS). Field work pursuant to the contract covered a three year period ending August 31, 1979. Extension of field work beyond the period covered by the contract will be noted where it occurred. Data gathered in the field during the study fell into three categories: vegetational surveys; wildlife surveys; and, recreational use surveys.

Prior to the onset of the study it was anticipated that Mobil might implement a pilot project to test the feasibility of recovering uranium by in-situ mining. With Mobil no longer actively involved in the Long Pines some of the objectives laid down prior to this study obviously cannot be met. The purpose of this report is to fulfill the following:

(1) to identify potential conflicts between in-situ mining in the Long Pines and vicinity and wildilife populations and develop criteria for eliminating, reducing or mitigating those conflicts;

(2) to furnish ecological data necessary to monitor in-situ mining on vegetation and wildlife populations; and

(3) to recommend revegetation techniques or innovations necessary to replace wildlife habitat disturbed by mining.

\section{STUDY AREA}

National forest lands of the Long Pines unit occur almost entirely in eastcentral Carter County, Montana (Figure 1). A small portion of this unit lies in Harding County, South Dakota which borders the study area on the east. Ekalaka, the Carter County seat, is situated about 13 miles $(21 \mathrm{~km})$ northwest of the Long Pines, while the small rural community of Camp Crook, South Dakota 1 ies about 4 miles (6 km) from the southeast corner of the Long Pines.

The study area includes $191 \mathrm{mi} .2$ (495 km²) of which national forest lands make up 54 percent. Private inholdings as well as private lands extending 1 to 2 miles from the national forest boundary account for 43 percent. The remaining 3 percent are administered by the State of Montana and the U.S. Bureau of Land Management, USDI (BLM). Land ownership on the study area is illustrated in Appendix Figure 1.

Carter County has been described as rural and agricultural with livestock ranching being the principal industry (U.S. Bureau of Reclamation 1972). Like several other rural counties in eastern Montana, Carter County has experienced a gradual decline in human population since 1950. A census in 1970 reported a population of 1,956 people 


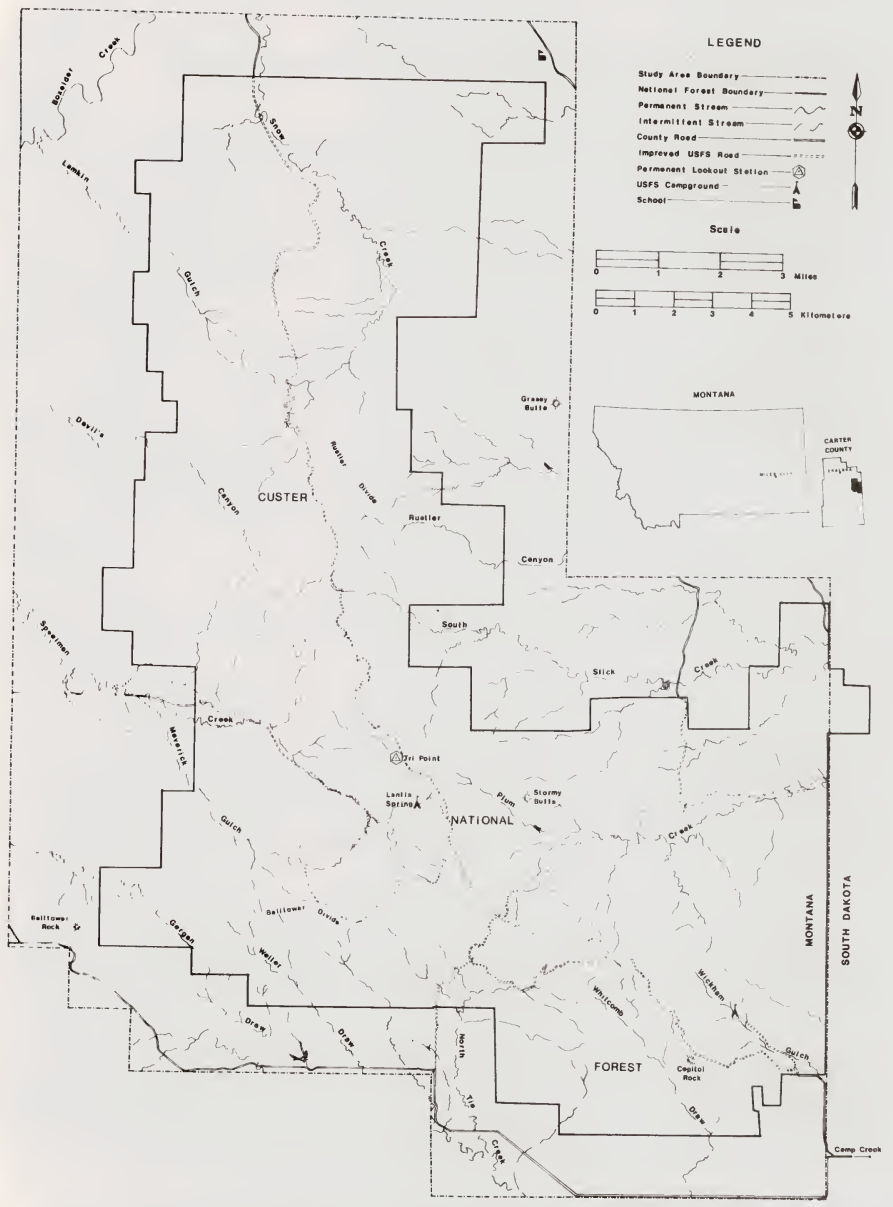

Fiqure 1. The Lonq Pines study area, Carter County, Montana. 
and an average population density of 0.6 people/mi.2 (J.4/knf) (Montana Department Community Affairs 1975).

\section{Physiography}

The study area lies in a portion of the Missouri Plateau which has not been subjected to glaciation or uplifting (Fenneman 1931, Perry 1935). The landscape in both Carter County, Montana and Harding County', South Dakota consists of a rolling upland plain dissected by many comparatively shallow drainages with broad flat divides. Several mesas and series of ridges, consisting of sedimentary rock, rise above the surrounding plain. In addition to the Long Pines, similar upland areas include the Ekalaka Hills, Chalk Buttes, and Sheep Mountains in Carter County and the Short Pines, Slim Buttes, and Cave Hills in Harding County.

The study area is drained by the Little Missouri River and its tributaries. Boxelder Creek, which intersects the northwest corner of the study area (Figure 1), is the only perennial flowing stream. Streams originating in the Long Pines have watersheds of 12 to $36 \mathrm{mi} .2$ (31 to $93 \mathrm{~km} 2$ ) (U.S. Forest Service 1976a).

Elevational differences on the study area range from 4,130 to 3,091 feet $(1,259$ to $912 \mathrm{~m})$. Highest elevations occur in the central and south central portions of the Lonq Pines ranging from about 3,800 to over 4,100 feet $(1158$ to $1250 \mathrm{~m})$ with prominant features including the Belltower Divide, the Rustler Divide and Stormy Butte (Figures 1 and 2). Other easily recognizable land forms include Capitol Rock in the southeast portion of the Long Pines and Belltower Rock adjacent to the southwest corner.

Geology and Subsurface Hydrology

Bauer (1924) described the area as a region of nearly horizontal rocks of upper Cretaceous and early Tertiary origin lying on the northeast flank of the Black Hills Uplift southwest of the Cedar Creek (BakerGlendive) Anticline. Perry (1935), Denson and Gill (1965), Miller (1979) and others have described the stratigraphy of the region. Pierre shale is the oldest formation exposed in the region but does not outcrop in the study area. It is composed of upper Cretaceous marine materials and impedes either upward or downward movement of water. Fox Hills sandstone, comprised of a sequence of marine and continental sandstone and shale also of Cretaceous origin, overlies Pierre shale and is exposed along the extreme western edge of the study area (Figure 2). The Hell Creek Formation directly overlies Fox Hills sandstone. Many of the badland features throughout the study area indicate an outcropping of this formation. The Fox Hills-lower Hell Creek aquifer produces abundant 

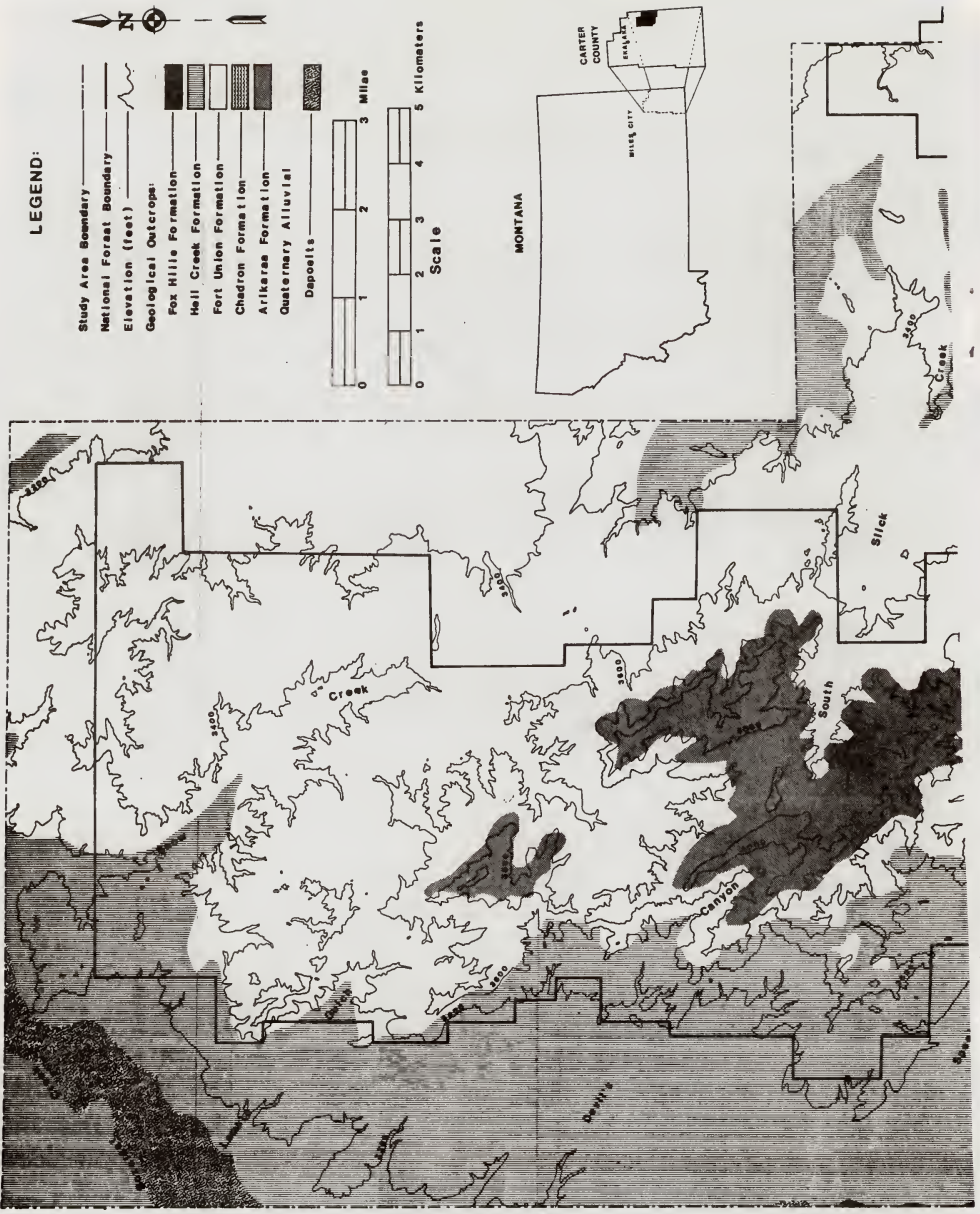

Figure 2. Elevational relief and outcropping of geological strata in the Long Pines study area. 


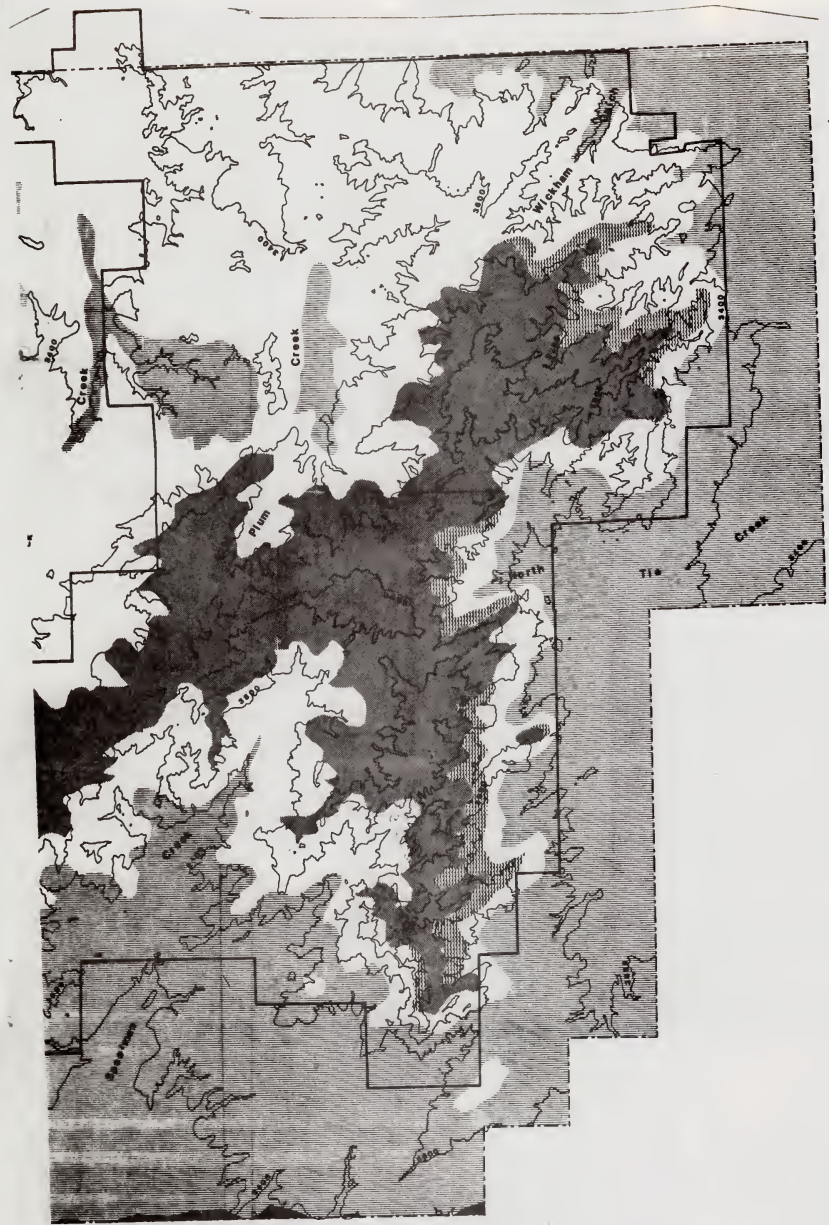

Figure 2 (continued).) 
quantities of water throughout the region (Montana Bureau of Mines and U.S. Geological Survey 1978) and is the most extensively used (Miller 1979). The Ludlow, or lignitic member, of the Fort Union Formation of Paleocene origin, overlies the Hell Creek Formation and outcroppings occur throughout the study area although predominantly on the north and east sides (Figure 2). Ledges and prismatic columns of light yellow sandstone and occasional outcroppings of scoria and lenses of lignite are characteristic of this formation. Shale or clav of the Ludlow member forms a contract zone from which many seeps and springs arise throughout the Sioux District (U.S. Forest Service 1976a). Most developed sources of qround water in the Long Pines, both for livestock and human consumption, come from th is aquifer (Montana Bureau of Mines and U.S. Geological Survey 1978). The Long Pines are capped by sandstones of the Chadron Formation of the White River Group and the Arikaree Formation. The Chadron Formation, composed of materials laid down during the 01 igocene, is exposed only along the rimrocks near the southern edge of the Long Pines, while the Arikaree, of Miocene origin, occurs throughout the central and southcentral portions of elevations of 3,800 feet $(1,158 \mathrm{~m})$ and above (Figure 2). These strata serve as recharge areas from local precipitation.

Soils

Soils of the study area are largely residual being derived from sedimentary rock over which they occur (Bauer 1924). The Soil Conservation Service, USDA (SCS) conducted a preliminary survey of soils in the Long Pines for the Forest Service in 1975 in conjunction with an intensive soil survey throughout Carter County (Unpublished). Soils of the uplands portion of the Long Pines are classified as loamy and are described as relatively young, and containing abundant amounts of coarse rocky fragments. Soils identified in this portion include those of the Dast, Vebar, Reeder, Barvon and Cabba Series. Soils in these upland portions are generally described as steep to very steep, deep to shallow and excessively drained (Carter County Conservation District 1976).

Soils of the rolling grassland areas have been described as coarse loamy soils including those of the Adger and Nobe Series. These are generally deep, well drained, gently to strongly sloping and containing sandy loam to clay surface layers. Soils of the Adger Series are formed in alluvium and have low permeability. Soils along the floodplain of Boxelder Creek are nearly level to undulating, deep and well drained.

\section{climate}

The climate of the region is typically semi-arid and continental, characterized by large seasonal and daily temperature fluctuations, light to moderate precipitation which is often irregular in time and coverage, low relative humidity and occasional high winds (U.S. Forest Service 1976a). During the study, monthly temperature and precipitation data 
were taken from that recorded at Ekalaka and Camp Crook (U.S. Dept. Commerce 1976, 1977, 1978, 1979). The two stations occur at elevations of 3,425 and 3,120 feet $(1,044$ and $951 \mathrm{~m})$, respectively. The station at Ekalaka is slightly cooler and receives somewhat qreater annual precipitation than does Camp Crook (Figure 3 ). These differences result from elevational and orographic influences. It somewhat greater amounts of precipitation than do either Ekalaka or Camp Crook.

Coldest and warmest average monthly temperatures at both stations normal ly occur during January and July, respectively, while more than half the normal annual precipitation occurs as rain from May through July (Figure 3). Monthly data recorded at the two stations during this study appear in Appendix Tables 1 and 2 .

Precipitation and average temperatures were quite variable during the study as determined from complete records kept at Ekalaka (Table 1). The first year of study, which ended August 31, 1977, was abnormally dry and warm. January 1977 was an exception to this trend and was characterized by an average monthly temperature $8.8 \mathrm{~F}(4.8 \mathrm{C})$ below normal and monthly precipitation $0.65 \mathrm{in}$. (17 mm) above normal. However, these harsh conditions improved during early February. The winters of 1977-78 and 1978-79 were comparatively harsher than that of 1976-77. Snow began accumulating in November of both years and persisted through March. Average monthly temperatures from December through February of both winters varied from 5.6 to $15.1 \mathrm{~F}(4.5$ to $8.3 \mathrm{C})$ below normal. Precipitation greatly exceeded normals only during winter 1977-78 (Table 1). Above normal precipitation during spring 1978 gave rise to abundant vegetative
growth the following summer.

Land use

Livestock production has been the principal agricultural activity in Carter County since the early $1880^{\prime}$ s. Federal noncropland and private state agricultural land make up 29 and 71 percent of the county, respectively (U.S. Bureau of Reclamation 1972). Of the latter category, 86 percent is classified as rangeland. The study area includes 5,741 acres $(2,324$ ha) of hay and croplands which accounts for about 5 percent of the study area. There are presently 18 grazing allotments in the Long Pines leased by 25 permittees most of which live adjacent to the national forest boundary. Approximately 14,584 animal unit months (AuM's) were permitted in the Long Pines in 1979. The grazing season on the national forest runs from May 16 to November 1.

Timber has been harvested in the Long Pines since early settlement of the area, but silvicultural practices were not initiated until 1920 (U.S. Forest Service 1976b). Approximately 500,000 board feet of timber have been harvested annualiy in recent years affecting roughly 100 acres
$(40 \mathrm{ha})$ per year. 
Table 1. Seasonal departures from normal precipitation and temperatures from September 1976 through August 1979 as derived from monthly data compared to a 30-year average (1941-1970) for Ekalaka,

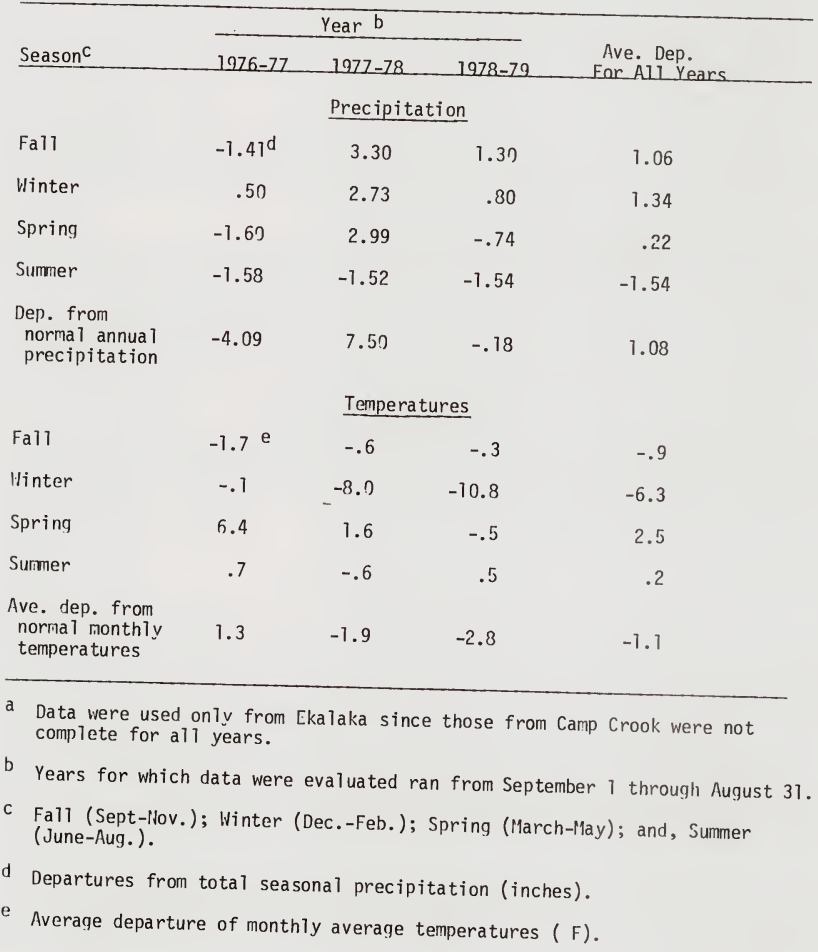



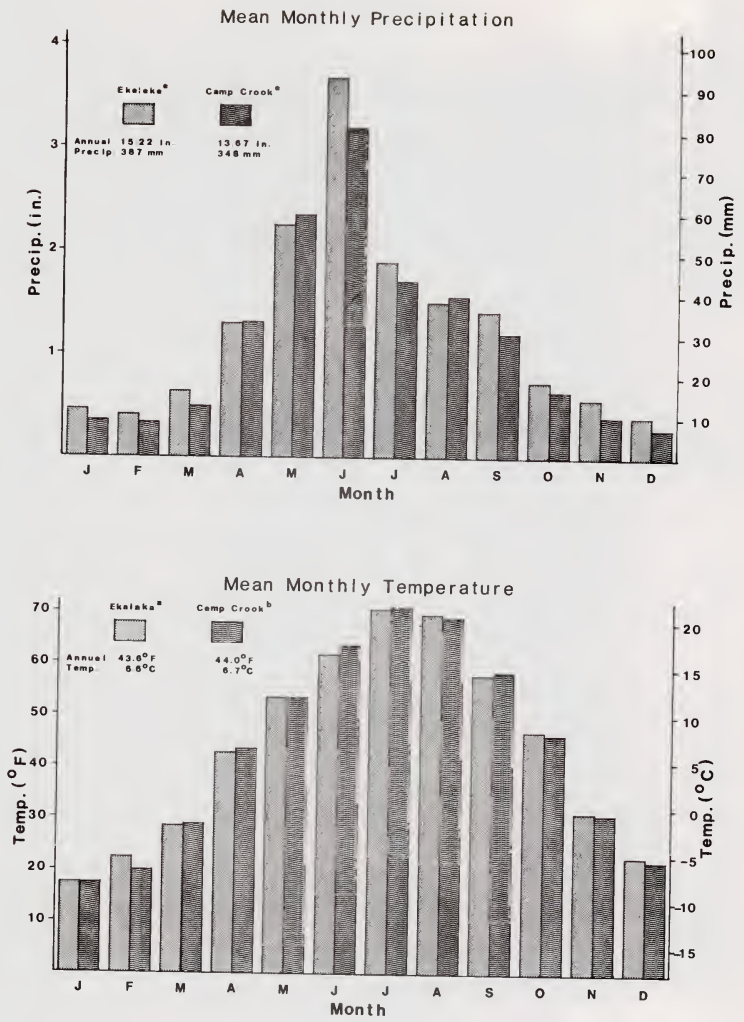

US Dept. Comm.t 1941.1970

buss $(10780)+1698.1087$

Figure 3. Mean monthly precipitation and temperatures for Ekalaka, Montana and Camp Crook, South Dakota. 


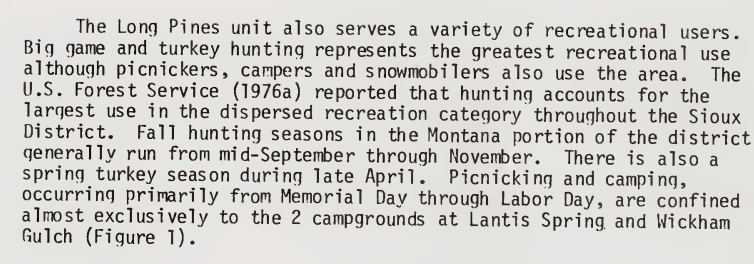




\section{PART I - DESCRIPTION OF VEGETATIONAL COMMUNITIES}

Vegetatively the Long Pines area consists of an upland dominated by ponderosa pine (Pinus ponderosa) with hardwoods confined to the draws extending into the lowlands, while the lowlands are dominated by prairie and badland communities. Ponderosa pine is the only coniferous forest species occurring in southeastern Montana (Arno 1979). The U.S. Forest Service (1976a) described 10 ecosystems, three dominated by pine, in the Sioux District in terms of topographical, soils and gross vegetative characteristics from interpretation of aerial photographs. DuBois (1979) described the species composition of plant communities that occurred in breeding bird study plots and along transect routes in the Long Pines study area. Jonas (1966) described vegetational communities in the Long Pines in terms of size class of timber and species composition in both timbered and nontimbered comminities with reference to their use by Merriam's turkey. Several researchers studied grassland, pine and shrub communities in the Little Missouri Drainage of western North Dakota similar to those found in the Long Pines study area (Dix 1958, Potter and Green 1964, and Sanford 1970).

This phase of study dealt with a subjective analys is of vegetational communities occurring in the study area with emphasis on successional trends in terms of habitat and cover types (Daubenmire 1968). All sites capable of supporting the same climax plant commity comprise a habitat type, whereas cover types reflect just the present dominants or existing communities, regardless of successional status. An attempt was made to identify environmental factors influencing distribution of plant species and communities. Determination of relative abundance and species composition of vegetal communities as well as identifying factors influencing their distribution are essential to quantifying habitat use by wildlife, to revegetating areas disturbed by mining, and to prioritizing plant communities on the basis of their sensitivity to disturbance and/or restoration potential.

\section{Procedures}

The Department of Fish, Wildlife and Parks contracted mapping of major habitat groups in the study area to Ecological Consulting Service (ECS), ECON Inc., Helena, Montana during 1976. False-color infrared aerial photographs (1:80,000 scale), taken during 1975, were used to produce $7 \frac{1}{2}$-minute base photo-quads $(1: 24,000$ scale) and to make the photo-interpretation. An 01d Delft Scanning Stereoscope was used to make the interpretation which was delineated on transparent overlays and transferred to base map scale using a Map-0-Graph 55C. Several limitations are inherent to this type of mapping (U.S. Forest Service 1976a). Perhaps the most pertinent of these was that small scale (i.e. 1:80,000) photos offer insufficient detail to adequately delineate all types. The contracted work did not include ground truthing.

Twenty-four cover types were identified on the basis of dominant tree overstory, shrub or grass species present during initial reconnaissance of the study area in fall 1976. Following a review of pertinent literature many of those cover types were combined using a subjective analysis. 
Forty-eight sites were sampled which had been selected with the aid of the cover map (Appendix Fiqure 2). Slope and exposure were recorded for each site. Slope was categorized by 150 classes and occasionally checked with a Suunto $\mathrm{Clinometer.} \mathrm{Species} \mathrm{composition} \mathrm{was} \mathrm{determined} \mathrm{by} \mathrm{sampling}$ vegetation within $202 \times 5$ decimeter plots (Daubenmi re 1959) at $5-\mathrm{ft} .(1.5 \mathrm{~m})$ intervals along a $100-\mathrm{ft} .(30.5 \mathrm{~m})$ transect line at each site. When practical transects were placed parallel to the contour. Common and scientific names of plants are from Booth (1950), Booth and Wright (1959) and Johnson and Nichols (1970). Canopy of stands of ponderosa pine was estimated from sites selected on the base photo-quads using a dot grid.

Yearly variations in precipitation, particularly rainfall during the growing season (Table 1), obviously affected growth, and canopy coverage of many grass and forb species. I felt that percent frequency among plots and percent constancy among sites adequately described composition and relative abundance. Use of percent frequency better faciliated comparisons between years in light of yearly variations in canopy coverage due to precipitation and grazing pressure. Similarity in species composition between pairs of sites sampled in each community was estimated with Sorensen's Index of Similarity (Dix 1958) where coefficients of 100 and 0 represent complete similarity and dissimilarity, respectively. The purpose was to determine if distribution of key plant species varied with gradient and/or exposure but was not used to class ify plant communities.

\section{Results and Discussion}

Eight major habitat groups were identified on the study area which included ponderosa pine-xeric grassland/shrub, ponderosa pine-mesic shrub, riparian tree/shrub, grassland park, prairie grassland, sagebrush-grassland, badland breaks and agricultural. Each habitat group was broadly defined on the bas is of topographic, edaphic and vegetal characteristics. Some consisted of two or three habitat types, while others were restricted to a single cover type. Pine covered approximately 28 percent of the study area, primarily in upland areas on soils derived from sandstones of the Fort Union and Arikaree Formations (Figure 2). Grassland parks and prairie grasslands accounted for about 61 percent of the study area. Riparian tree/ shrub habitat accounted for roughly three percent of the study area but was underestimated since such sites could not be differentiated where they extended into stands of ponderosa pine. Sagebrush-grasslands (less than 0.05 percent of study area) were perhaps also under-represented due to difficulty differentiating them from prairie-grass lands from the map scale used in the interpretation. Average frequency and constancy among sites for all taxa found in major habitat groups appear in Appendix
Tables 3 and 4 .

\section{Ponderosa Pine-Xeric Grassland/Shrub}

Distribution of this group (Figure 4), representing the driest sites supporting pine in the study area, appeared closely associated with parent material of the Fort Union Formation and possibly the Arikaree Formation. 
Such sites are characterized by sandy, well-drained soils whereas pine gives way to grasslands as soils become more silty or clayey (U.S Forest Service 1976a).

As many as three habitat types of the Pinus ponderosa series were represented in this group. The most prevalent was the Pinus ponderosal Agropyron spicatum h.t. (Pipo/Agsp). Since indicator species and the sites on which this type occurredwere similar to types described by Pfister et al. (1977) and Jorgensen (1979) it was considered synonymous to them. Sites sampled in the Long Pines varied from 150 to 450 in gradient. In addition to the site dominants, diagnostic species included little bluestem (Andropogon scoparius), prairie sandreed (Calamovilfa longifolia) and skunkbush sumac (Rhus trilobata) as well as many less abundant species (Table 2 and Appendix Table 3). Coarse loamy upland soils were associated with comparatively open stands of timber and well developed understories of grass (SCS, USDA unpublished). Timber canopy on these sites varied from 33 to 50 percent. Although slopes consisting of colluvium contained the same complement of species, pine was nearly absent in most cases. Such sites also contained an occasional Rocky Mountain juniper (Juniperus scopulorum). A type similar to this was described by Brown (1971) in the Ashland District of the Custer National Forest. The relatively rocky soils on these sites in the Long Pines were at least partially influenced by shale parent material perhaps serving to limit the abundance of pine. Although the Pipo/Agsp h.t. occurred on all exposures, skunkbush sumac was more abundant on southerly exposures. Its frequency averaged 40 percent on south exposures and 21 percent on all other exposures combined.

A Pinus ponderosa/Andropogon c.t. (Pipo/Androp), similar to a habitat type described by Pfister et al (1977), was represented throughout the study area and in many cases was difficult to distinguish from the Pipo/ Agsp h.t. as far as site characteristics were concerned. It was most abundant in the northeast corner of the study area east of Snow Creek (Figure 1). A Pinus ponderosa/Juniperus horizontalis c.t. (Pipo/Juho) was also restricted to the northeast portion of the study area often in close association with the Pipo/Androp c.t. Their distribution appeared confined to coulee heads and sidehills with very coarse textured soils. No sites were sampled in these two types.

\section{Ponderosa Pine-Mesic Shrub}

The ponderosa pine-mesic shrub group (Figure 5), confined to the wetter sites in the study area, supporting pine, included the Pinus ponderosa/Symphoricarpos albus (Pipo/Sya 1 ) and Pinus ponderosa/Prunus virainiana (Pipo/Prvi) h.t.'s (Pfister et al. 1977). Canopy of timber on these sites averaged 76 percent. Shrubs abundant in the understory of both types combined included Oregon grape (Berberis repens), chokecherry (Prunus virginiana), common snowberry (Symphoricarpos albus) and western snowberry (S. occidentalis). Important herbaceous species included yarrow (Achillea millefolium), cudweed sagewort (Artemisia ludoviciana), 

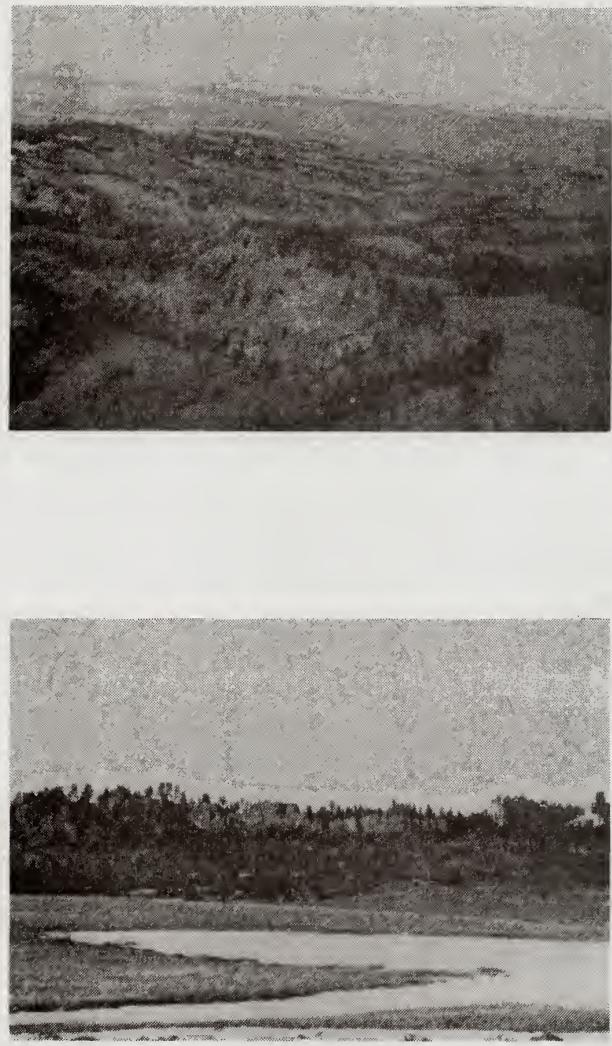

Fiqure 4. Ponderosa pine-xeric grassland/shrub habitat group in the north end of the study area (top) and along the south edge (bottom). 

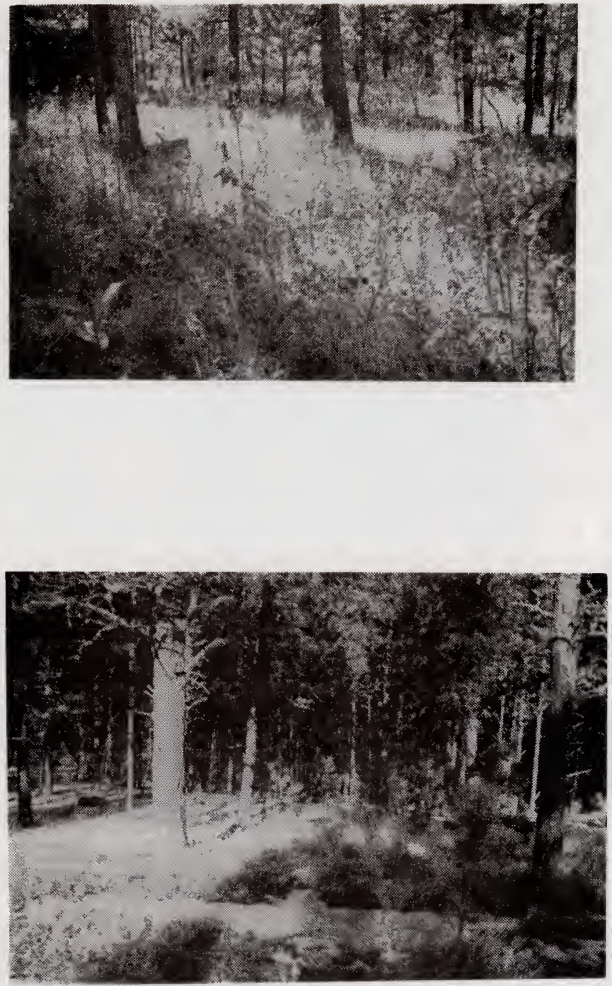

Figure 5. Ponderosa pine-mesic shrub habitat group. 
Table 2. Diagnostic vegetation of habitat groups in the Long Pines study area as determined from analysis of
$9602 \times 5$ decimeter plots among 49 sites.

\begin{tabular}{|c|c|c|c|c|c|c|c|c|}
\hline Taxa $^{\mathrm{a}}$ & $\begin{array}{c}\text { P.Pine-Xeric } \\
\text { Pipol } \\
\text { Agsp } \\
\text { ht } \\
10^{b}\end{array}$ & $\begin{array}{c}\text { P. Pine-Mesic } \\
\text { Pipo/ } \\
\text { Syal } \\
\text { ht } \\
11 \\
\end{array}$ & $\begin{array}{l}\text { Ripa } \\
\text { Frpe/ } \\
\text { Acnu } \\
\text { ct } \\
3\end{array}$ & $\begin{array}{l}\text { rian } \\
\text { Syal/ } \\
\text { Popr } \\
\text { ct } \\
2\end{array}$ & $\begin{array}{l}\text { Grassland } \\
\text { Park }\end{array}$ & $\begin{array}{l}\text { Prairie } \\
\text { Grss1. }\end{array}$ & \begin{tabular}{l}
\multicolumn{2}{c}{ Sage-Grssl } \\
Artrl Arcal \\
Agrop Agsm \\
ht \\
4
\end{tabular} & $\begin{array}{l}\text { Badland } \\
\text { Breaks }\end{array}$ \\
\hline
\end{tabular}

GRASSES \& GRASSLIKE:

Agropyron spp.

Agropyron smithii

Agropyron spicatum

Andropogon scoparius

Aristida longiseta

Bouteloua gracilis

Bromus japonicus

Calamovilfa longifolia

Carex spp.

Koeleria cristata

Poa pratensis

Poa secunda

Stipa comata

Stipa viridula

\section{FORBS:}

Achillea millefolium

Artemisia frigida

Artemisia ludoviciana

Aster spp.

Echinaceae pallida

Galium aparine

Galium boreale

Phlox hoodii

Plantago purshii

Psoralea argophylla

Psoralea esculenta

$\begin{array}{llll}-c & - & - & - \\ + & - & 0 & + \\ + & - & 0 & 0 \\ + & - & 0 & 0 \\ - & - & 0 & 0 \\ - & - & 0 & 0 \\ - & - & 0 & 0 \\ + & 0 & 0 & 0 \\ + & + & + & - \\ 0 & - & 0 & - \\ - & + & + & + \\ 0 & 0 & 0 & 0 \\ + & - & 0 & 0 \\ - & + & 0 & -\end{array}$

$\begin{array}{lll}+^{2} & - & - \\ + & + & - \\ 0 & 0 & - \\ 0 & 0 & 0 \\ 0 & 0 & 0 \\ + & - & - \\ + & 0 & - \\ 0 & 0 & 0 \\ - & - & - \\ + & + & - \\ - & + & - \\ + & 0 & 0 \\ - & + & - \\ + & + & -\end{array}$

$\begin{array}{ll}\overline{0} & + \\ \overline{0} & + \\ 0 & - \\ + & 0 \\ + & - \\ 0 & 0 \\ 0 & 0 \\ 0 & 0 \\ 0 & 0\end{array}$


Table 2 continued.

\begin{tabular}{|c|c|c|c|c|c|c|c|c|c|}
\hline Taxa & $\begin{array}{c}\text { P.Pine-Keric } \\
\text { Pipol } \\
\text { Agsp } \\
\text { ht } \\
10 \\
\end{array}$ & $\begin{array}{c}\text { P.Pine-Mesic } \\
\text { Pipol } \\
\text { Syal } \\
\text { ht } \\
11 \\
\end{array}$ & $\begin{array}{l}\text { Ripa } \\
\text { Frpe/ } \\
\text { Acnu } \\
\text { ct } \\
3 \\
\end{array}$ & $\begin{array}{l}\text { rian } \\
\text { Syal/ } \\
\text { Popr } \\
\text { ct } \\
2 \\
\end{array}$ & $\begin{array}{l}\text { Grassland } \\
\text { Park }\end{array}$ & $\begin{array}{l}\text { Prairie } \\
\text { Grssl. }\end{array}$ & $\begin{array}{l}\text { Sage-G } \\
\text { Artr/ } \\
\text { Agrop } \\
\text { ht } \\
4 \\
\end{array}$ & $\begin{array}{l}\text { Grssl. } \\
\text { Arca/ } \\
\text { Agsm } \\
\text { ht } \\
2 \\
\end{array}$ & $\begin{array}{l}\text { Badland } \\
\text { Breaks }\end{array}$ \\
\hline \multicolumn{10}{|l|}{ FORBS: continued } \\
\hline Ratibida columnifera & 0 & 0 & 0 & 0 & + & - & 0 & 0 & 0 \\
\hline Smilacina stellata & 0 & - & + & 0 & 0 & 0 & 0 & 0 & 0 \\
\hline Taraxicum officinale & 0 & - & + & - & - & 0 & 0 & 0 & 0 \\
\hline Thalictrum venulosum & 0 & - & + & 0 & 0 & 0 & 0 & 0 & 0 \\
\hline Vicia americana & + & - & - & - & 0 & 0 & - & - & 0 \\
\hline \multicolumn{10}{|l|}{ SHRUBS: } \\
\hline Artemisia cana & 0 & 0 & 0 & 0 & 0 & - & - & + & - \\
\hline Artemisia tridentata & 0 & 0 & 0 & 0 & 0 & - & + & 0 & - \\
\hline Berberis repens & 0 & - & + & 0 & 0 & 0 & 0 & 0 & 0 \\
\hline Chrysothamnus spp. & 0 & 0 & 0 & 0 & 0 & 0 & 0 & 0 & + \\
\hline Prunus virginiana & 0 & - & + & 0 & 0 & 0 & 0 & 0 & 0 \\
\hline Rhus trilobata & + & - & 0 & 0 & 0 & 0 & 0 & 0 & 0 \\
\hline Rosa spp. & - & - & - & + & - & - & 0 & 0 & 0 \\
\hline $\begin{array}{l}\text { Symphoricarpos albus } \\
\text { Symphoricarpos }\end{array}$ & - & + & + & + & 0 & 0 & 0 & 0 & 0 \\
\hline occidentalis & 0 & - & + & + & 0 & 0 & 0 & 0 & 0 \\
\hline
\end{tabular}

a Includes only those taxa with an average frequency of 15 percent or greater and a constancy of 67 percent or greater in at least 1 type. Average frequency and constancy of all taxa occurring in plots sampled appear in Appendix Tables 3 and 4.

b Number of sites sampled in each vegetal community.

c $+=$ site dominants (average frequency and constancy of at least 15 and 67 percent, respectively); - = subordinate species; and $0=$ absent among sites sampled. 
bedstraw (Galium spp.), Kentucky bluegrass (Poa pratensis) and green needlegrass (Stipa viridula). Many less abundant grasses and forbs were also found on these sites.

These mesic sites were associated with coarse rocky, sandy-loam soils occurring on steep to rolling upland topography underlain by sandstone primarily of the Arikaree Formation (Figure 2). In portions of the study area where the Fort Union Formation is exposed similar vegetation is confined to northerly exposures.

Data from sites sampled amonq the two habitat types were combined. It appeared that understory composition changed with gradient (Figure 6 ). Pfister et al. (1977) described a snowberry and Oregon grape phase of the Pipo/Syal h.t. Each pair of sites sampled among the 2 habitat types were aligned by slope and exposure as well as those pairs sharing neither attribute. Average coefficients of similarity were 55, 47, and 39 , respectively, suggesting that distribution and relative abundance of key species in one or the other habitat type varied with steepness of slope (Figure 6). Common snowberry predominated among understory shrubs on level to gently rolling upland sites but gave way to Oregon grape as gradients exceeded $15^{\circ}$. Frequency of chokecherry also increased with gradient and was most bundant on the steepest sites sampled (Figure 6).

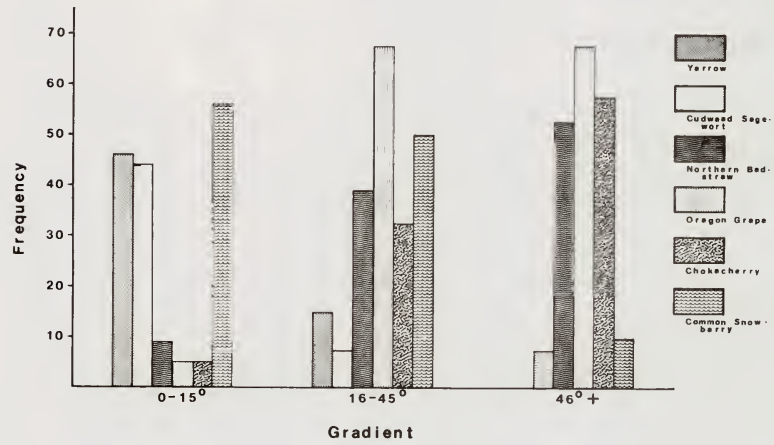

Figure 6. Changes in frequency of 6 taxa on ponderosa pine-mesic shrub sites in relation to gradient. 
This suggested that the Pipo/Syal and Pipo/Prvi h.t.'s can perhaps be differentiated on the basis of slope as influenced by moisture gradient. Among forbs, yarrow and cudweed sagewort decreased in abundance as gradient increased, while that of northern bedstraw (Galium boreale) increased. In the study area these habitat types were most prevalent at elevations above 3,600 feet $(1,097 \mathrm{~m})$ where they were not restricted exclusively to northerly exposures. These uplands undoubtedly receive greater annual precipitation than do the surrounding plains. Since the uplands also serve as recharge areas many of these sites may receive moisture in excess of precipitation as water percolates through soil and semi-impervious layers of sandstone. Snow also tends to accumulate in the draws and depressions, and, where shaded from direct sunlight, it melts at a comparatively slower rate. Dix (1958) among others, suggested soil moisture to be the most important single factor determining floral composition and abundance, while other variables, such as slope and exposure, are important only in so far as they influence soil mo isture.

\section{Riparian Tree/Shrub}

Deciduous trees and/or shrubs were the dominant vegetation in many draws (Figure 7) throuqhout the studv area. Such vegetation also occurred on other mesic sites including depressions and folds formed as a result of sloughing of earth beneath rimrocks and buttes. This group occurred on miscellaneous landforms varying from steep to nearly level, while soils were deep and well to poorly drained varying in texture from sand to clay and occasionally gravel (SCS, USDA unpublished). As these conditions changed, species composition in the overstory also changed. This group somewhat resembled a continuum as explained by Daubenmire (1968).

Quaking aspen (Populus tremuloides) occurred in the upper-most reaches of the drainages intermingled with stands of pine. Aspen stands sampled in the Black Hills and Bear Lodge Mountains were associated with coarse textured soils on cool, moist sites (Severson and Thilenius 1976). The successional status of aspen in the Long Pines was unclear. DuBois (1979) noted that many stands in the Long Pines contained few mature trees and many dead trees with little or no regrowth. This was attributed to suppression of fires and foraging by ungulates suggesting that aspen may represent a fire sere or cover type. Kentucky bluegrass, sedges (Carex spp.), Oregon grape and snowberry were the most abundant species in the understory (DuBois 1979). A relict stand of paper birch (Betula papyrifera) occurred in Maverick Gulch on a site that also supported aspen.

Farther down the draws moisture was sufficient to support stands of fleshy hawthorne (Crataegus succulenta) and wild plum (Prunus americana) which spatially replaced aspen. As stream channels became more developed these species eventually give way to green ash (Fraxinus pennsyluanica) and boxelder (Acer negundo). Ross and Hunter (1976) described these species as part of the hardwood climax forest scattered throughout eastern Montana. Understory composition was sampled at 3 sites (Table 2 
and Appendix Table 3). Dominant understory shrubs included Oregon grape, chokecherry, and snowberry; key grasses and forbs included sedges, ryegrass (Elymus spp.), and many others. Silver buffalo-berry (Shepherdia argentea) occurred with or in place of green ash and boxelder throughout the study area.

Snowberry was a component of the understory throughout the continuum. Common and western snowberry occurred in dense stands lacking a tree overstory. Hild rose (Rosa spp.) was also abundant on these sites. Predominant herbaceous vegetation on these sites included western wheatgrass (Agropyron smithii), sedges, Kentucky bluegrass, green needlegrass, yarrow, cudweed sagewort, northern bedstraw and horsemint. These sites may have lacked sufficient moisture to support a tree overstory. Both sites sampled occurred in draws with a gradient of less than 150 .

Plains cottonwood (Populus deltoides) was scattered throughout some of the lower drainages, and in some cases occurred in homogeneous stands. Soils in these areas were alluvial and occasionally underla in by gravel. Jorgensen (1979) described a Populus deltoides/Symphoricarpos occidentalis h.t. in central Montana which occurred on sites similar to those occupied by its counterpart in the Long Pines study area.

\section{Grasseand Park}

Grassland parks (Figure 8) included natural openings in the canopy of pine where grasses and sedges constituted the dominant vegetative cover. They were confined to comparatively gentle upland terrain on gradients usually not exceeding $15^{\circ}$ and averaged 37 acres ( $13 \mathrm{ha}$ ) in size, al though some exceeded 180 acres $(73 \mathrm{ha})$. Soils on these upland grasslands were moderately deep to deep, well drained with loam or silt loam surface layers from materials weathered from sandstone, siltstone and shale (SCS, USDA unpublished). Major soils included those of the Reeder and Barvon series, both of which are residual upland soils.

Floral composition was typical of grassland vegetation of the eastern Montana sedimentary plains (Ross and Hunter 1976). Grassland parks would perhaps best be described as a cover type since successional status is unknown. Grasses and grasslike plants predominating on these parks included western wheatgrass, sedges, needle-and-thread (Stipa comata), prairie junegrass (Koeleria cristata), Kentucky bluegrass, blue grama (Bouteloua gracilis) and unidentified wheatgrasses (Agropyron spp.), probably mostly thickspike wheatgrass (A. dasystachyum); cudweed sagewort, yarrow, aster (Aster spp.), fringed sagewort (Artemisia frigida) and prairie coneflower (Ratibida columnifera) were abundant among forbs. Presence of shrubs on
these sites was negligible.

Grazing and fire, or a combination of these factors, may have had a comparatively greater influence on herbaceous composition than soil and climate. As a result the site potential on grasslands is sometimes rather difficult to predict (Ross and Hunter 1976). Ponderosa pine was invading some of the grassland parks which was perhaps partially due to fire suppression. Annual precipitation during the last two decades was noticeably 

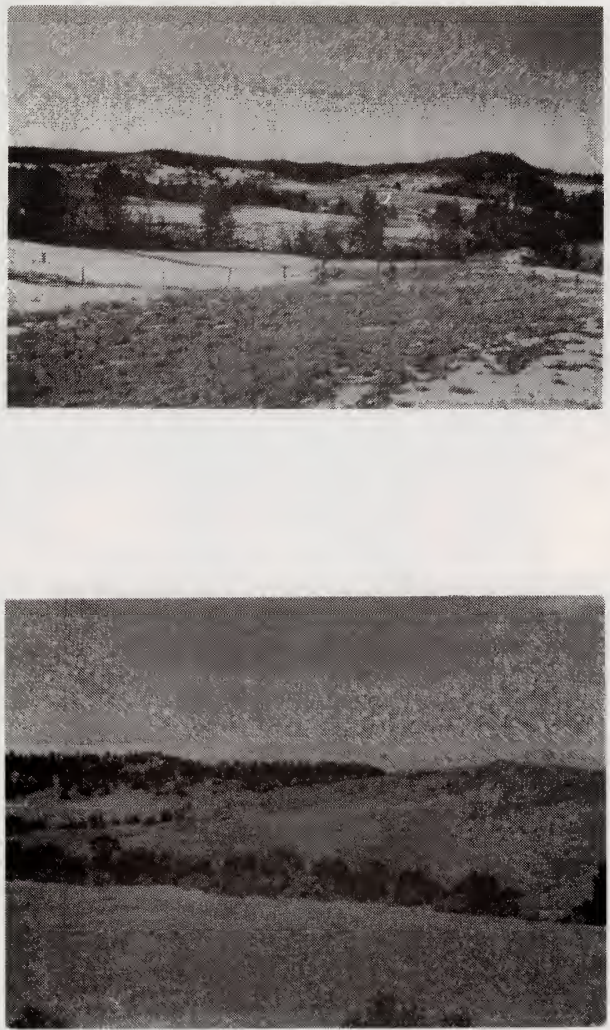

Figure 7. Riparian tree/shrub habitat group (Fraxinus pennsylvanicus) Acer negundo cover type). 

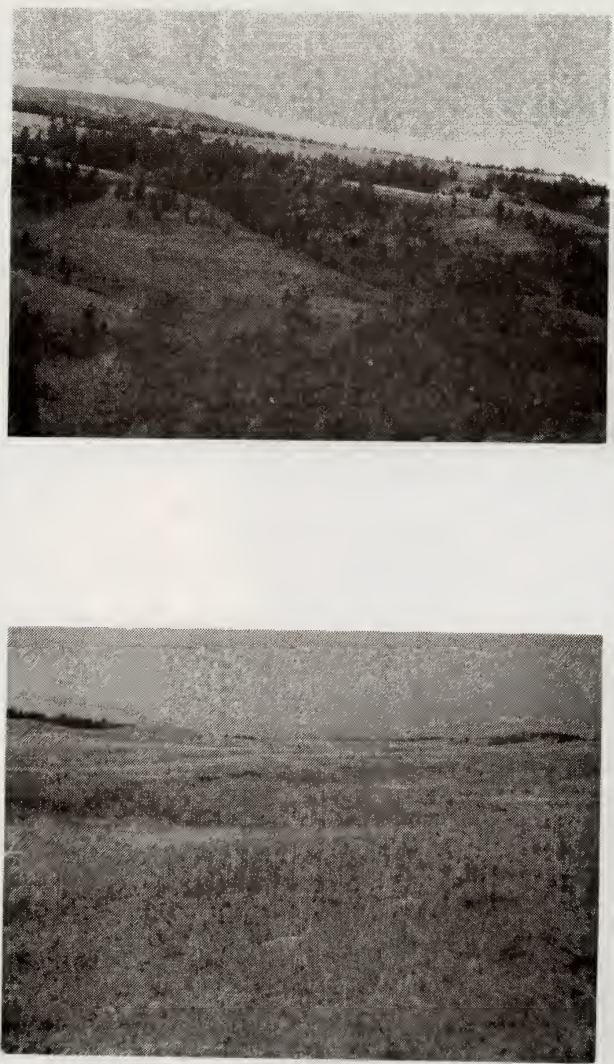

Fiqure 8. Grassland parks (top photo) and prairie grasslands (bottom photo). 
greater than that received during previous decades. Seasonal and annual moisture conditions probably were more favorable for invasion by pine on these sites, whereas pine was perhaps not able to compete with grasses under drier conditions. For example, 30-year normal annual precipitation for Ekalaka from 1931-60 and 1941-70 was 13.22 and 15.22 inches (336 and $387 \mathrm{~mm})$, respectively. Average annual precipitation from 1971-78 was 19.29 inches $(490 \mathrm{~mm})$.

Patches of little bluestem were found in many grassland parks particularly in areas where Fort Union sandstones were exposed. Such sites may be synonymous with a Muhlenbergia cuspidata/Andropogon scoparius h.t. (Mucu/Ansc) described by Jorgensen (1979). Plains muhly (Muhlenbergia cuspidata) occurred throughout the study area (Appendix Tables 3 and 4). Kentucky bluegrass was abundant on the more mesic sites resembling those supporting a Poa pratensis/Artemisia ludoviciana h.t. (Popr/Arlu) also described by Jorgensen (1979).

\section{Prairie Grassland}

Uninterrupted grasslands along the lower drainages, alluvial plains, and rolling lowland topography were collectively categorized as prairie grasslands (Figure 8). As opposed to grassland parks, soils associated with prairie grasslands also included those of alluvial origin consisting of well drained coarse loamy soils to more clayey soils having relatively low permeability (SCS, USDA unpublished). Major soils associated with rolling grasslands included those of the Adger and Nobe series which occurred primarily in pan spot areas. Floral composition differed little from that found in the grassland parks (Table 2 and Appendix Table 4). Scattered stands of little bluestem and prairie sandreed were al so abundant in prairie grasslands.

Each combination of pairs of sites sampled on grassland parks and prairie grasslands combined were aligned by qradient, exposure and pairs sharing neither attribute. Coefficients of similarity indicated that some plant species favored certain slopes and/or exposures over others (Fiqure 9). Western wheatgrass and prairie junegrass were positively associated with one another over changes in slope and exposure. Both exhibited considerable ecological amplitude as compared to other grasses occurring in the grassland communities, but were most abundant among sites sampled on table lands and gentle east exposures (Figure 9). Cudweed sagewort and Kentucky bluegrass were also abundant on table lands as opposed to grasslands on relatively level flood plains. Needleand-thread occurred more frequently on drier sites such as south exposures and gentle sloping lowlands which receive less moisture than comparable upland sites. Jorgensen (1979) indicated that needle-and-thread was a habitat type dominant on sandy soils.

\section{Sagebrush-Grasseand}

Two habitat types were identified in this group. An Artemisia tridentata/Agropyron h.t. (Artr/Agrop) occurred on sites associated with 


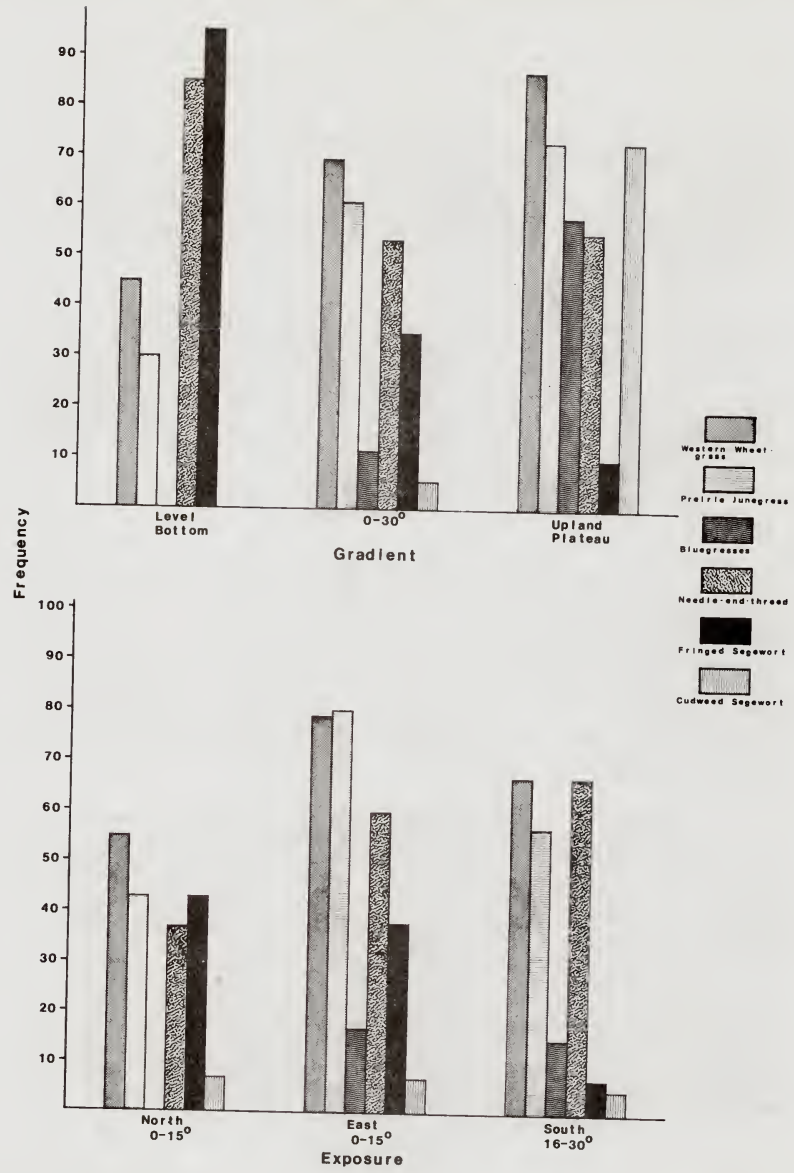

Figure 9. Frequency of 6 key species on grassland parks and prairie grasslands in relation to slope and exposure. 
clay soils (Figure 10), some of which were saline (Ross and Hunter 1976). This habitat type occurred primarily in the lowlands on the southern and the western edges of the study area. Such clayey soils were likely derived from materials of the Hell Creek Formation. Western wheatgrass and prairie junegrass were abundant on the four sites sampled. Unidentifed wheatgrasses, probably thickspike wheatgrass, were also abundant. Forbs were scarce on this habitat type. Occurrence of shrubs other than big sagebrush (Artemisia tridentata) was negligible.

An Artemisia cana/Agropyron smithii h.t. (Arca/Agsm) was restricted primarily to flood plain areas where soils were more silty than those associated with the Artr/Agrop h.t. (Figure 10). A similar habitat type was described by Jorgensen (1979). Dominant grasslike vegetation included western wheatgrass, sedges, prairie junegrass, Kentucky bluegrass and qreen needlegrass. Yarrow, cudweed sagewort, and aster predominated among forbs. Silver sagebrush (Artemisia cana) was the only shrub present on the two sites sampled.

\section{Badland Breaks}

Ross and Hunter (1976) defined badlands as a complex of nearly barren lands broken by drainages interspersed with small grassland areas. Badland sites in the study are represented by eroded out-croppings of the Hell Creek formation (Figure 11). Two sites were sampled where bluebunch wheatgrass and green rabbitbrush (Chrysothamnus viscidiflorus) appeared to be site dominants (Table 2). Rocky Mountain juniper was the dominant species on other sites and in some cases occurred in dense stands on north exposures.

\section{Agricultural}

Cultivated portions of the prairie grassland and sagebrushgrassland areas represented an agricultural disturbance or cover type (Fiqure 11). These occurred mostly on private lands surrounding the national forest and included cereal grain fields and hay meadows. 

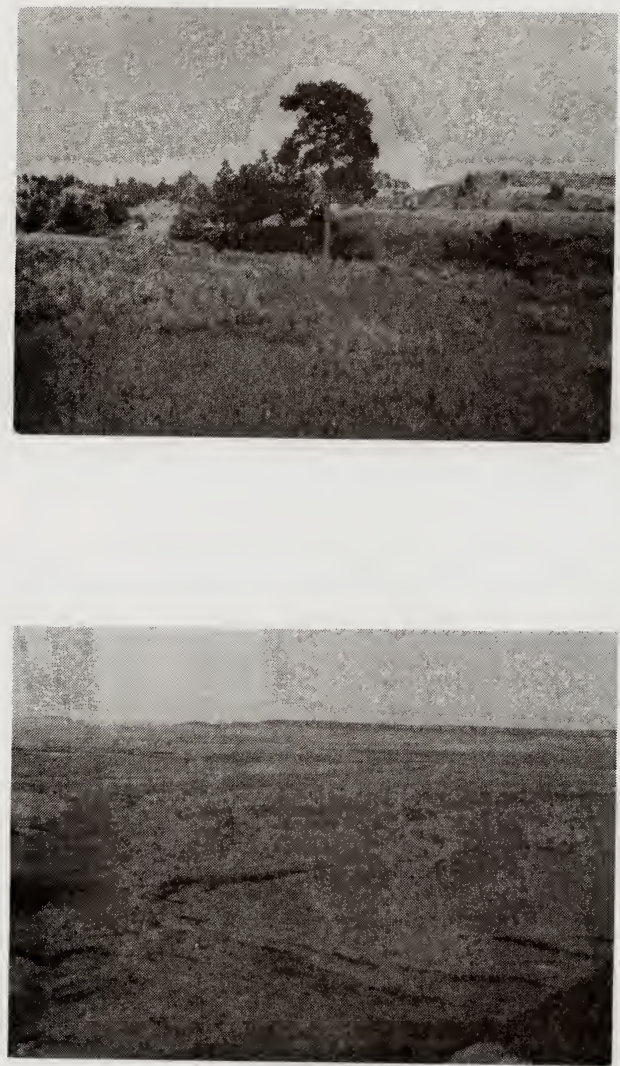

Figure 10. Sagebrush-grassland habitat group: Artemisia tridentatal Agropyron h.t. (top); and Artemisia cana/Agropyron smithii h.t. (bottom). 

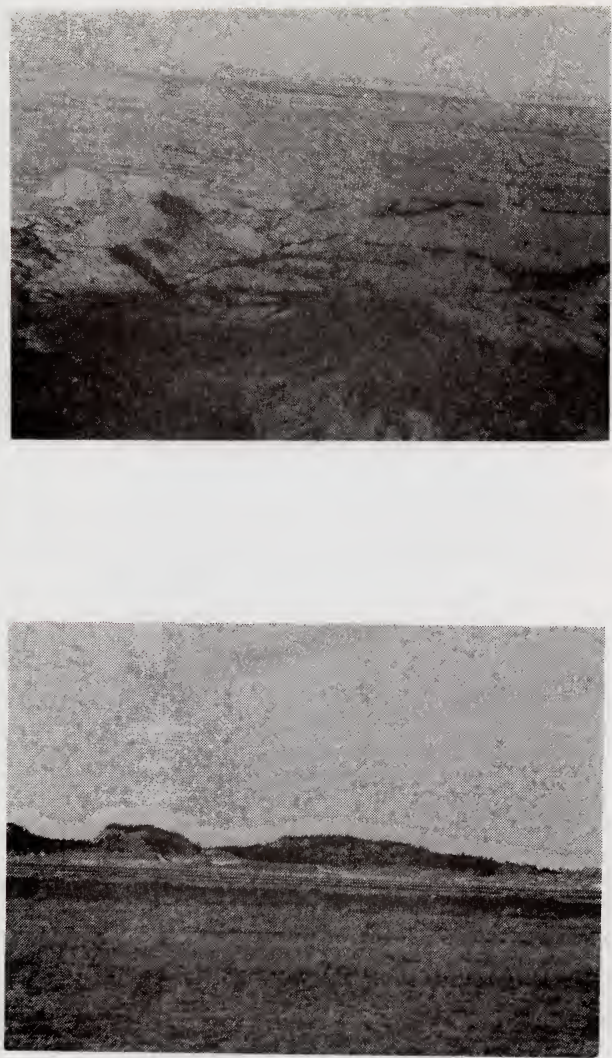

Figure 11. Badland breaks habitat group (top) and agricultural group (bottom). 


\section{PART II - WILDLIFE SURVEYS AND INVENTORIES}

The diverse nature of the Long Pines study area, in terms of topography, soils, climate and vegetation, provides habitat for a variety of avian and mammalian fauna, many of which perhaps would not occur together under more homogeneous environmental conditions. Wildlife investigations were conducted throughout the 3 year contract period, and, in some cases, beyond that through November 1979. Some individual species, or groups of species, were studied more intensively than others for reasons of relative abundance and/or ecoloqical importance and due to 1 imitations imposed by funding, allotted time and manpower. Wildlife research, conducted in the area prior to th is study, was not duplicated but will be incorporated through literature citation.

Procedures

\section{Big Game}

Distribution and range use of ungulate populations in the study area were evaluated from aerial and/or ground reconnaissance. These trends were evaluated only during summer for antelope (Antilocapra americanal and during all seasons for deer. Seasonal and annual trends for white-tailed deer (Odocoileus virginiana) were estimated primarily from vehicle survey routes since a dense canopy of timber where this species primarily occurred precluded obtaining meaningful data from aerial surveys. These data were supplemented with miscellaneous observations obtained incidental to other activities including aerial surveys to census other species. Data for mule deer 10 . hemionus) were obtained from both ground and aerial surveys. An attempt was made to cover major vehicle survey routes 4 times per season, although deep snow precluded extensive travel by 4 -wheel drive during 2 of the 3 winters and many routes were not surveyed. Travel on the national forest was possible only by snowmobile after December 15, 1978. The study area was divided into 3 subunits of approximately equal size with roads and trails separating them to facilitate aerial surveys of mule deer and antelope. Each subunit was surveyed for deer at least once per season with a PA-18 $150 \mathrm{~h}$.p. fixed-wing aircraft. Each individual or group of animals observed during both ground and aerial surveys was located to the nearest mile2 (2.6 km²) with the aid of a grid map. Date and time of observation and the habitat group, gradient and exposure occupied by each individual or group were al so recorded. Effort was directed toward visiting habitat groups during routine vehicle surveys in proportion to their representation in the study area. Chi-square was used to test the null hypothes is that major habitat groups were not used out of proportion to their abundance on the study area (Snedecor and Cochran
1967 ).

During the 3 winters of the study 110 white-tailed deer were captured and individually marked on the national forest, and their movements were monitored to aid in interpretation of distribution and range use data. 
Of these, 16. were fitted with neck collars containing radio transmitters with frequencies varying from 150.825 to $151.075 \mathrm{MHz}$, while the remainder were fitted with individually recognizable neck collars (Dusek 1977). Transmitting and receiving equipment were obtained from AVM Instrument Co. and Wildlife Materials, Inc. A numbered metal tag was affixed to the right ear of all deer captured. A plastic livestock ear tag, marked with patterns to designate the trap site was affixed to the left ear of each fawn. Radio-equipped deer were systematically relocated only during daylight or twilight at 1 to 2 week intervals while observations of collared deer were obtained incidental to other activities. Effort was directed towards locating radioed deer during periods when animals were resting as well as during periods of feeding or traveling. Most observations of collared deer were made when they were travelling or feeding. Data recorded for all individually marked animals included date and time of observation, location and the habitat group the animal occupied. For radioed whitetails, location was estimated to the nearest $.01 \mathrm{~km}^{2}$ (1 ha) and was later entered on a computer file us ing UTM coordinates. From this the maximum area used (home range), the geographical center of activity, and minimum, maximum, and mean distances between successive relocations between any 2 given dates were obtained (Lonner 1976). Whether radioed animals were actually seen or not when located was also
recorded.

Year-long trends in food habits among both species of deer were estimated from analys is of 1-qt. $(0.951)$ samples from rumens of deer collected during the study, deer taken by hunters, and from deer having died as a result of accidents, poaching, trapping or predation. Samples were analyzed by a technique used by Wilkins (1957) and others. Results were tabulated using the aggregate percentage method (Martin et al. 1946).

Annual and seasonal trends in physical condition of deer were evaluated with the aid of kidney fat indices from specimens, an expression of the fat surrounding the kidney as a percent of the weight of the kidney, using a method described by Allen (1968). When practical, deer collected during the study were weighed prior to and following field dressing. A dressing index was calculated expressing the field dressed weight as a percent of the whole weight. Diastemal and antler measurements were taken from hunter-killed specimens during 1978 and 1979 as part of a study to evaluate condition of deer populations throughout southeastern Montana (Swenson and Knapp 1979).

Total numbers of antelope on the study area during summer were estimated by direct count from census flights during July or early August of 1977-79. Population numbers of mule deer were estimated by direct count from aerial censuses during mid-December through mid-January of 1977-78 and 1978-79. Due to difficulty in censusing white-tailed deer in dense timber from fixed-wing aircraft, an early winter population was estimated using a technique described by Caughley (1977). Th is involved estimating the whitetail population in the study area from the mule deer 
population, estimated by direct count, using a ratio of numbers of deer sumerved between the two species from vehicle route surveys during spring,

Herd composition and annual production of all 3 big game species were evaluated from observed age and sex ratios obtained from ground and/or aerial surveys. For deer, changes in herd composition throughout the year were evaluated with the aid of sex and age ratios obtained from deer harvested by hunters, from whitetails trapped during winter, and from deer having died during late winter and early spring. Tooth eruption and wear techniques (Severinghaus 1949, Robinette et al. 1957) were used to estimate the age of deer specimens. A sample of hunter-killed deer of both species, whose ages were estimated by eruption and wear at $2{ }_{2}^{1}+$ years, was aged by analysis of cementum lavers of the first incisor (Low and Cowan 1963, Gilbert 1966).

Breeding potential among both species of deer was determined from analvsis of reproductive tracts of females collected from December through May including those that died as a result of trapping. Ovaries were examined for corpora lutea to estimate incidence of ovulation (Cheatum 1949). Ovaries were hardened in 10 percent formaline, sectioned with a razor and examined. The sex of fetuses was determined from females taken after mid-January. Weights and forehead-rump measurements were recorded for fetuses to estimate the peaks of breeding and fawn drop (Cheatum and Morton 1946, Hudson and Browman 1959). Composition of the kill by sex and species, hunter success, and harvest within the national forest portion of the study area'vere estimated from questionnaires distributed among parties hunting in the Long Pines during fall of 1976-79 and aided in evaluating population trends.

\section{Small Game}

The level of effort devoted to small game, which included primarily 3 upland bird species, was less intensive than that devoted to big game animals. Distribution and production data were obtained incidental to gathering similar data for deer from routine vehicle surveys. From midMarch through mid-May of each year, surveys were conducted to locate lekking areas (dancing grounds) and determine numbers of breeding male sharp-tailed grouse (Pediocetes phasianellus) using procedures described by Pepper (1972). Low-level flights by fixed-wing aircraft also aided

Fall food habits of Merriam's turkey and sharptails were evaluated from analys is of crop contents (Pepper 1972) from birds taken by hunters. Results were tabulated by the aggregate percentage method (Martin et al.
1946 ).

\section{Nongame}

The nongame portion of the project was performed in cooperation with Washington State University and Montana State University with work performed by graduate students. Both studies dealt with nongame birds (Allen 
Results and Discussion

\section{White-tailed Deer}

East of the Cont,nental Divide in Montana, populations of whitetailed deer occur primarily in association with bottomlands of major stream courses but also in mountain foothill areas of central Montana and in ponderosa pine uplands in southeastern Montana including the Long Pines (A1len 1971). Range use and/or population data regarding white-tailed deer in eastern Montana are 1 imited almost exclusively to the work of Allen (1968), Martinka (1968), Kamps (1969), Swenson (1978a) and Haml in (1979). Knapp (1977) reported habitat use by whitetails along major drainages in the Birney-Decker area of southeastern Montana but emphasized substantial use of adjacent upland ponderosa pine sites by this species. Similar habitat use by whitetails was observed in the Bull Mountains of southcentral Montana near the Musselshell River, although small isolated populations occurred in the uplands some distance from the river (Dusek 1978).

White-tailed deer were numerically the most abundant big game species occurring in the study area and on the national forest in particular. They have accounted for a greater proportion of total annual deer harvest in the hunting district which includes the study area (781) than in southeastern Montana as a whole (Eustace and Swenson 1977).

Range Use

\section{Distribution}

White-tailed deer inhabited at one time of year or another, approximately 44 percent of the study area, including the uplands in the central and southern portions (Figure 12). Seasonal ranges included at least 91 percent of seasonal observations. Isolated areas, where numbers observed accounted for less than 0.5 percent of seasonal totals, were not considered part of seasonal ranges.

It was estimated that whitetails used only 28 percent of the study area during winter. Inspite of inaccessibility of the national forest to travel by wheeled vehicle, due to deep snow during at least a portion of all winters, 83 percent of white-tails observed during winter occurred on the national forest. The sample included observations obtained incidental to aerial surveys for mule deer in some of the inaccessible areas.

Comparatively heavy use of nontimbered lowlands adjacent to the national forest was observed from mid to late March through April and was at least partially influenced by spring greenup while snow cover still remained in some upland areas. Such observations were most numerous during the first hour of daylight. Whether this phenomenon represented a seasonal shift in distribution or just increased daily movements from winter will be discussed later. Differences in distribution from spring through fall could not be differentiated and were combined (Figure 12). During the period 64 percent of the observations occurred on the 



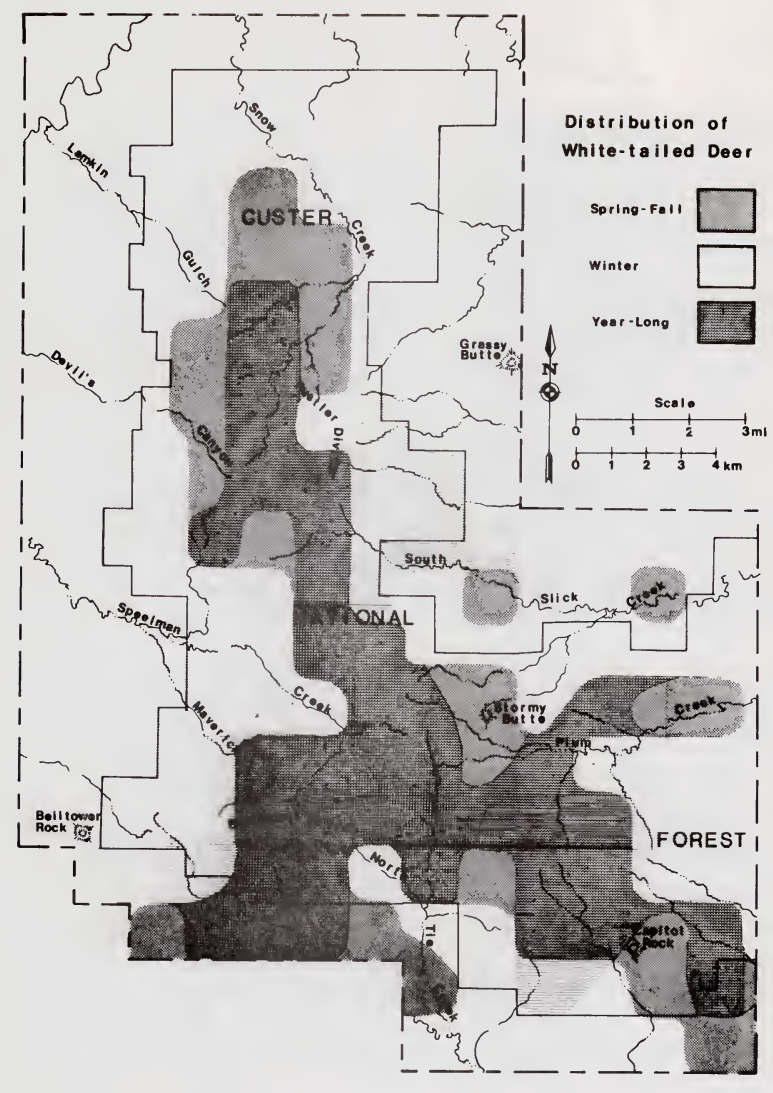

Figure 12. Distribution of white-tailed deer in the Long Pines study area. 
national forest representing a decrease from winter.

Data obtained during the spring-fall period better represented distribution of whitetails quantitatively than did that of the winter period since all survey routes were accessible and travelled repeatedly from April through November. During the spring-fall period, approximately 35 percent of the observations occurred in an area including the Belltower Divide, the north side of Tie Creek, the south side of Speelman Creek and the upper reaches of Maverick Gulch. This region accounted for roughly 18 percent of the part of the study area inhabited by white-tailed deer suggesting a comparatively higher population density in that region. Whitetails also appeared to occur in comparatively greater numbers in the upper reaches of Plum and South Slick Creeks since 19 percent of the spring-fall observations were made in that area which accounted for approximately 9 percent of the area inhabited by the species.

\section{Site Selection}

Annual and seasonal use of habitat groups, slopes and exposures by white-tailed deer were evaluated from 2,134 observations from September 1976 through November 1979 (Table 3, 4, and 5). Five hundred relocations of radioed whitetails also aided in evaluating habitat use (Table 3 ). Relocations of radioed deer were almost evenly distributed between early morning, late morning, afternoon and evening periods, whereas combined data from vehicle route and miscellaneous surveys were most numerous during evening (Appendix Table 5).

A significant preference for combined ponderosa pine habitats and an avoidance of combined nontimbered native comunities was determined on an annual basis for both observation and relocation data $(P<0.05)$, although this trend was not significant during all seasons. A preference for agricultural areas, as determined from vehicle survey observations, was significant only during spring. This preference was not apparent from relocation of radioed deer perhaps due, in part, to the relatively small number of relocations (500) or to differences in the time of day data were qathered by the 2 methods. The proportion of radioed deer occurring in pine habitats or on riparian tree/shrub sites was generally greater than that among deer observed from vehicle survey routes suggesting a bias inherent on dependence on observing animals. However, both types of data indicated similar annual and seasonal trends in use among all types
(Table 3 ).

Slopes of 150 or less accounted for 77 percent of yearlong observations (Table 4), and 51 percent occurred on level ridge-tops and drainage bottoms (Table 5). Use of north and west exposures by whitetails may have been underestimated due to dense timber making deer more difficult to observe as compared to east and south exposures.

Fall - Ponderosa pine-mesic shrub sites received greater use than others during fall (Table 3 ). Other communities receiving substantial use during this season included the riparian tree/shrub and ponderosa pine-xeric grassland/shrub sites and agricultural areas. The relative 
Table 3. Seasonal and annual use of habitat groups by white-tailed deer in the Long Pines study area as determined from routine vehicle surveys and tracking radio-equipped deer.

\begin{tabular}{|c|c|c|c|c|c|}
\hline $\begin{array}{l}\text { Habitat } \\
\text { Group }\end{array}$ & $\begin{array}{l}\text { Fall } \\
559 \\
(84)^{a} \\
\end{array}$ & $\begin{array}{c}\text { Winter } \\
335 \\
(112) \\
\end{array}$ & $\begin{array}{c}\text { Spring } \\
717 \\
(163) \\
\end{array}$ & $\begin{array}{c}\text { Summer } \\
443 \\
(141) \\
\end{array}$ & $\begin{array}{l}\text { Annual } \\
2,054 \\
(500) \\
\end{array}$ \\
\hline $\begin{array}{l}\text { Ponderosa Pine-Xeric } \\
\text { Grassland/Shrub }\end{array}$ & $18(7)^{b}$ & $17(28)$ & $6(29)$ & $18(11)$ & $14(19)$ \\
\hline $\begin{array}{l}\text { Ponderosa Pine-Mesic } \\
\text { Shrub }\end{array}$ & $33(60)$ & $48(68)$ & $24(34)$ & $39(45)$ & $36(52)$ \\
\hline Riparian Tree/Shrub & $13(25)$ & $15(1)$ & $7(14)$ & $11(34)$ & $11(18)$ \\
\hline Grassland Park & $12(1)$ & $11(1)$ & $19(8)$ & $7(2)$ & $12(3)$ \\
\hline Prairie Grassland & $7(7)$ & $6(-)$ & $17(11)$ & $8(6)$ & $9(6)$ \\
\hline Sagebrush-Grassland & $2(-)$ & $2(-)$ & $3(1)$ & $1(-)$ & $2(t r)^{C}$ \\
\hline Badland Breaks & $-(-)$ & $-(-)$ & $-(-)$ & $-(-)$ & $-(-)$ \\
\hline Agricultura 1 & $16(-)$ & $2(2)$ & $25(2)$ & $16(3)$ & $15(2)$ \\
\hline
\end{tabular}

a Sample size: vehicle surveys (relocations of radioed deer).

b Percent of observations: vehicle surveys (radioed deer).

C Trace (a value less than .5 percent).

Table 4. Seasonal and annual distribution of white-tailed deer among four classes of gradient as determined from vehicle route surveys.

\begin{tabular}{lccccr}
\hline Gradient & Fal1 & Winter & Spring & Summer & Annua \\
$644^{\mathrm{a}}$ & 755 & 74 & 815 & 76 & 77 \\
\hline $0-150$ & $75^{\mathrm{b}}$ & 74 & 13 & 18 & 16 \\
$16-300$ & 17 & 18 & 5 & 5 & 6 \\
$31-450$ & 7 & 7 & 2 & 2 & 1 \\
$46^{0_{+}}$ & 1 & 1 & & \\
\hline
\end{tabular}

a Sample size

b Percent of observations. 
Table 5. Seasonal and annual distribution of white-tailed deer among level ridgetops, drainage bottoms and four exposures as determined from
vehicle route surveys.

\begin{tabular}{lccccc}
\hline Exposure & $\begin{array}{c}\text { Fal1 } \\
644 \mathrm{a}\end{array}$ & $\begin{array}{c}\text { Winter } \\
335\end{array}$ & $\begin{array}{c}\text { Spring } \\
715\end{array}$ & $\begin{array}{c}\text { Summer } \\
440\end{array}$ & $\begin{array}{c}\text { Annual } \\
2,134\end{array}$ \\
\hline Level Ridnetop & $24 \mathrm{~b}$ & 20 & 18 & 29 & 23 \\
Level Bottoms & 26 & 24 & 36 & 25 & 28 \\
North & 8 & 11 & 7 & 13 & 10 \\
East & 19 & 21 & 18 & 15 & 18 \\
South & 12 & 19 & 15 & 8 & 13 \\
West & 10 & 6 & 6 & 12 & 8 \\
\hline
\end{tabular}

a Sample size.

b Percent of observations.

absence of whitetails from grassland and sagebrush-grassland areas was significant during fall and during all seasons as determined from ground observations $(P<0.05)$. Generally, deer observed on prairie grassland or sagebrush-grassland areas were often travelling from agricultural areas, where they had fed, toward ponderosa pine types on or adjacent to the national forest. Riparian tree/shrub sites along the draws often served as avenues of travel, particularly where grain and hay fields were separated from timber by expanses of prairie grasslands and sagebrushqrasslands. Use of agriculturat areas by whitetails decreased from 24 to 8 percent from early to late fall, possibly influenced by the onset of hunting seasons during late October. No attempt was made to determine habitat use during nocturnal periods, although others have reported substantially greater use of nontimbered types, particularly agricultural areas, during nocturnal periods than during diurnal periods (Larson et al. 1978).

Winter - Coniferous habitat received its greatest yearlv use by white-tailed deer during winter, most of which occurred on ponderosa pinemesic shrub sites (Table 3). Snow depths on these sites approached or exceeded 2 feet $(0.61 \mathrm{~m})$ throughout the winters of 1977-78 and 1978-79, and travel between feeding and bedding sites was facilitated by a series of well-packed trails through the snow. A preference for ponderosa pine habitat was significant during winter as determined from both survey observations and relocation of radioed deer $(P<0.05)$. Daily movement from timbered sites was rare except for movement to and from neighboring haystacks. 
These results were in contrast to those of Martinka (1968) and Kamps (1969) who reported that whitetails continued to heavily use grain fields or deciduous tree/shrub types during winter in mountain foothill areas of central Montana. Selection of coniferous habitat as wintering areas in the Long Pines closely resembled that of whitetails in portions of the Midwest (Wetzel et a1. 1975, Larson et a1. 1978). The abnormally harsh temperature conditions of 1977-78 and 1978-79 may have exemplified the importance of ponderosa pine-mesic shrub sites to white-tailed deer in the Long Pines. Timber canopy was comparatively dense on these sites, averaging 76 percent. During storms whitetails used the densest stands including "doghair" as evidenced by tracks and trails through such areas immediately following a storm. Ozoga and Gysel (1972) reported that use of dense protective cover by deer increased during periods of low temperature and high calculated air chill regardless of snow cover. White-tailed deer prefer relatively dense stands of conifers for wintering areas because such areas offer thermal cover reducing loss of body heat (Ozoga 1968, Moen 1968, Drolet 1976).

Spring - A major shift in habitat use was evident from winter to spring (Table 3). Average monthly temperatures during March 1978 and 1979 were nearly tivice those reported for February of those years (Appendix Table 1 and 2), whereas cold winter temperatures dissipated during February 1977. During the latter two years, snow cover pers isted in the uplands through March and deer began to appear in the bottomlands about mid to late March, when snow cover had nearly disappeared. Drainage bottoms received their greatest yearly use by whitetails during spring (Table 5). Ponderosa pine-mesic shrub sites received their lowest yearly use during spring, although their use was still greater than that on other sites. Use of ponderosa pine-mesic shrub sites increased from 12 percent during early spring to 36 percent during late spring. Ground observations during spring revealed a significant preference for agricultural areas $(P<0.05)$. Grass land parks received comparatively heavy use, especially during early spring, when 23 percent of the observations occurred on those sites when such areas were beginning to green up. Radioed deer increased their use of ponderosa pine-xeric grassland/shrub sites during March perhaps as a result of snow disappearing from steep south and east exposures earlier than on rolling uplands.

Summer - Yearly differences in cover of herbaceous vegetation, resulting from fluctuations in rainfall during spring and early summer, didn't noticeably affect habitat use by whitetails between years. They increased their use of ponderosa pine-mesic shrub sites from spring (Table 3) and their preference for these sites, as determined from vehicle survey routes, was significant $(P<0.05)$. They also increased their use of riparian tree/shrub sites from spring. Ponderosa pine-mesic shrub and riparian sites represented some of the more mesic conditions existing on the study area. Water from natural seeps and developed springs and impoundments, combined with the canopy afforded by both deciduous and conifer tree cover during summer, may have moderated warm summer daytime temperatures through evaporation. Thus, ponderosa pine-mesic shrub sites 
may also have provided thermal cover for whitetails during summer. The avoidance of grassland and sagebrush-grassland areas combined was also significant as determined from both observation and relocation data. Although use of agricultural areas decreased from spring, their use increased from 9 to 23 percent from early to late summer as determined from survey observations. This was perhaps influenced by decreased availability of succulent herbaceous vegetation on adjacent upland areas. Increased use of agricultural areas during late summer was also reported
by Kamps (1969).

\section{Movements}

Fawns accounted for 60 percent of the white-tailed deer captured and marked on the national forest during the study, whereas adults and yearlings accounted for 36 and 4 percent, respectively. From this sample 9 adult females, 5 adult males and 2 yearling males were fitted with collars containing radio transmitters. Five radioed deer were still being monitored during late November 1979. Since late February 1977, 2 transmitters had failed, 2 deer discarded their radio collars, and 7 radioed animals died. As many as 8 , and as few as one, radioed deer were monitored at any given time. A total of 546 relocations were obtained. Thirteen radioed deer were monitored throughout one or more seasons and provided 522 relocations. Relocations per individual ranged from 5 to 101. An annual home range was the area within the smallest polvgon including all relocations for individuals whose movements were monitored during at least 4 consecutive seasons (Table 6). Annual home ranges varied in size among individuals reflecting their sedentary or migratory behavior. Seasonal home ranges and movements (Table 7) were more uniform among individuals. Seasons were arbitrarily chosen to commence on the first day of September, December, March and June for fall, winter, spring and summer, respectively.

Of 94 whitetails fitted with individually recognizable collars, 38 (40 percent) were observed one or more times, but only 4 were observed 10 or more times. Thirteen were known to have died following their capture and release. Forty-eight (51 percent) marked deer were never observed, or at least not positively identified, following their capture. Some fawns were known to lose their collars, which fit loosely to allow for growth, since individuals were occasionally observed that had plastic livestock ear tags, which were placed only on fawns, and no collar. From January 1977 through Auqust 1979, 157 observations were obtained from 38 marked deer. Thirty-six percent were made during spring probably due to heavy seasonal use of non-timbered habitat. Eight percent of the observations of marked deer included animals subsequently recaptured at other locations or during following winters. The proportion of collared deer observed, and positively identified, in coniferous habitat was lower than observations of unmarked deer from survey routes or from relocations of radioed deer and was disproportionately higher in prairie-agricultural habitat. Seasonal shifts in habitat use by collared deer were still apparent. Due to these observability biases, data from collared deer 
Table 6. Annual and seasonal home ranges of 13 white-tailed deer equipped with radio transmitters whose movements were monitored for at least one season from February 1977 through November 1979.

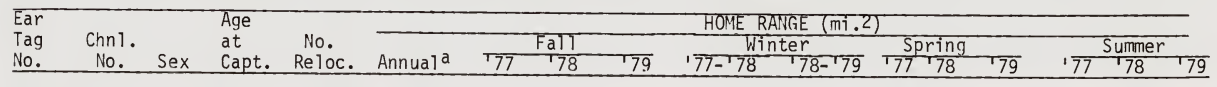

\begin{tabular}{|c|c|c|c|c|c|c|c|c|c|c|c|c|c|c|c|c|}
\hline $1752^{C} d$ & 6 & $\mathrm{~F}$ & $2 \frac{1}{2}+$ & 12 & - & - & - & - & - & - & 1.3 & - & - & 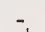 & - & - \\
\hline $1757^{\circ}$ & $8 / 5$ & $\mathrm{~F}$ & $2 \frac{1}{2}+$ & 72 & 2.9 & - & - & .1 & - & .7 & .4 & - & .5 & $t r^{b}$ & - & .1 \\
\hline $1762^{\mathrm{C}}$ & 2 & $F$ & $2 \frac{1}{2}+$ & 72 & 5.5 & .4 & - & - & .5 & - & .6 & 1.5 & - & .6 & 3.2 & - \\
\hline 1764 & 10 & $\mathrm{~F}$ & $2 \frac{1}{2}+$ & 15 & - & - & - & - & - & - & .4 & - & - & - & - & - \\
\hline 1766 & 7 & $F$ & $2 \frac{1}{2}+$ & 12 & - & - & - & - & .4 & - & - & - & - & - & - & - \\
\hline $1769^{c}$ & 5 & F & $2 \frac{1}{2}+$ & 101 & 10.4 & - & 3.0 & 4.8 & .7 & .3 & - & 3.7 & 2.7 & - & 2.6 & 1.9 \\
\hline $1772^{C}$ & 4 & $M$ & $2 \frac{1}{2}+$ & 27 & - & - & - & - & .5 & - & - & 1.1 & - & - & - & - \\
\hline $6805^{\circ}$ & 12 & $\mathrm{~F}$ & $2 \frac{1}{2}+$ & 31 & - & - & - & - & .1 & - & - & 1.6 & - & - & .1 & - \\
\hline 6813 & 6 & $M$ & $2 \frac{1}{2}+$ & 31 & - & - & - & - & $\operatorname{tr}$ & - & - & .5 & - & - & 1.2 & $\overline{-}$ \\
\hline $6844^{C}$ & 8 & $\mathrm{~F}$ & $2 \frac{1}{2}+$ & 46 & 28.9 & - & - & .4 & - & $\operatorname{tr}$ & - & - & 21.2 & - & - & 1.0 \\
\hline 6845 & 10 & M & $1 \frac{1}{2}$ & 11 & $\overline{-}$ & - & - & - & - &.$?$ & - & - & - & - & - & - \\
\hline 6848 & 12 & $M$ & $7 \frac{1}{2}$ & 47 & 3.8 & - & - & 3.0 & - & .1 & - & - & 1.0 & - & - & 1.6 \\
\hline 68 & 3 & M & $4^{\frac{1}{2}}+$ & 45 & .6 & - & - & .2 & - & tr & - & - & .3 & - & - & .1 \\
\hline
\end{tabular}

\begin{tabular}{llccccc} 
& Females & 11.9 & 1.7 & .3 & 3.4 & 1.2 \\
Average & Males & 2.2 & 1.6 & .2 & .7 & 1.0 \\
& All Deer & 8.9 & 1.7 & .2 & 1.1 \\
\hline
\end{tabular}

a Annual home ranges were computed only for deer that were monitored at least during 4 consecutive seasons.

b $\mathrm{tr}$ - seasonal home ranges were smaller than $0.05 \mathrm{mi} .2$.

c Included animals that moved from the Long Pines during late spring or summer.

d Animal was equipped with a second collar approximatelyli months after the first transmitter failed. 
Table 7. Seasonal mean consecutive distances and maximum distances travelled among 13 white-tailed deer equipped with radio transmitters.

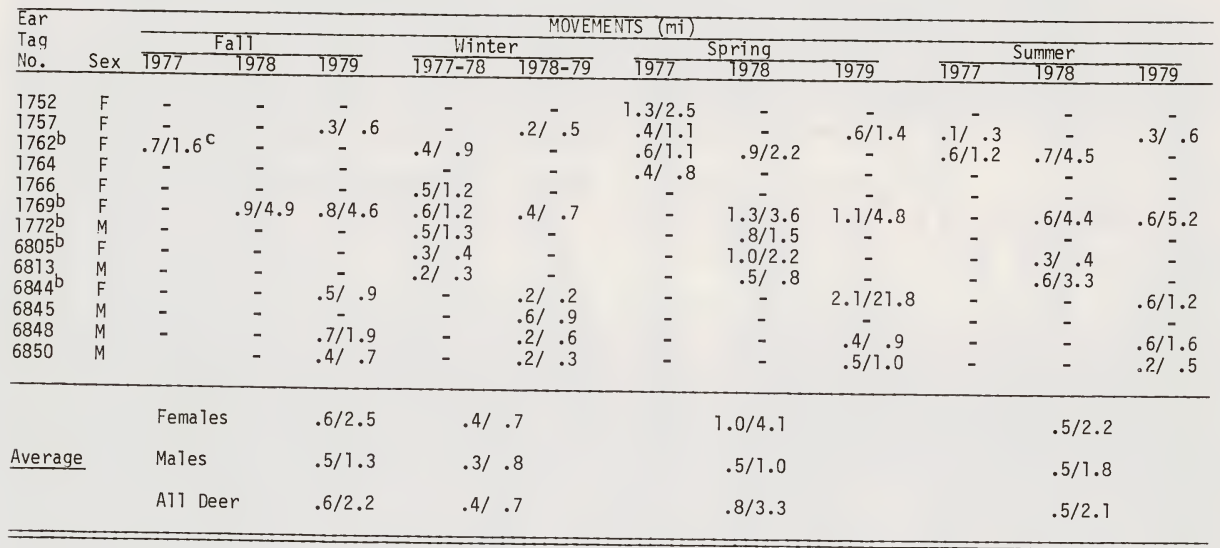

a Mean consecutive distances/maximum distance.

b Included animals that moved from the Long Pines during late spring or summer.

c Mean consecutive distance/maximum distance. 
were not used to evaluate movements of individual animals, but rather to determine gross changes in seasonal distribution or dispersal of the population (Figure 13).

Winter - Seasonal home ranges of radioed white-tailed deer were, without exception, smallest during winter and occupied only small portions of annual home ranges (Table 6). Movements between successive relocations also decreased during winter (Table 7 ). No noticeable differences in magnitude of home ranges and movements were found between sexes during winter. This agrees with the results of Sparrowe and Springer (1970). With the exception of two adult females relocated once in a haystack yard just outside the national forest boundary, winter activity of radioed whitetails occurred in conifer habitat within the forest (Table 3). Travel to and use of nearby haystacks by whitetails generally occurred during periods of twilight and darkness. Most observations of individually marked deer (20 of 22) occurred in conifer habitat during winter daylight periods.

Winter home ranges of radioed animals averaged $0.4 \mathrm{mi} .2\left(1.0 \mathrm{~km}^{2}\right)$ during 1977-78 but only $0.1 \mathrm{mi} .2\left(0.3 \mathrm{~km}^{2}\right)$ during 1978-79. An adult female (1769), monitored during both winters, spent both in the same portion of her annual home range as expressed by location of the respective centers of activity (Fiqure 14). Her winter home range was smaller during winter 1978-79 (Table 6). Average monthly temperatures were colder (Appendix Tables 1 and 2) and snow began accumulating two weeks earlier during winter 1978-79 than during the previous year. Rongstad and Tester (1969) also reported that winter home ranges of white-tailed deer in Minnesota decreased with increased snow depth. Selection of coniferous habitat combined with reduced movement by individuals during winter in the Long Pines closely resembled the yarding habit of white-tailed deer in Michigan (Ozoga 1968, Verme 1968). Such behavior presumably served to reduce loss of body heat and conserve energy, thus enhancing chances of survival during periods of extremely cold weather.

Spring - A noticeable change in daily and seasonal movements commenced during mid-March 1977 but not until late March of 1978 and 1979. Although average daily temperatures increased (Appendix Tables 1 and 2) snow cover persisted through March of the latter two years. Fifty-six percent of collared deer sighted during spring occurred in prairie-agricultural habitat, representing dispersal from the national forest to private land along the north side bottomlands of Tie Creek. The sightings occurred 1.5 to 3 miles $(2.4$ to $4.8 \mathrm{~km})$ from the Belltower Divide where those individuals were captured and marked. This sample did not include deer captured south of the Belltower Divide in the upper Speelman Creek drainage.

Home ranges were larger during spring and movements were greater than those of winter among all radioed deer (Tables 6 and 7). Some remained sedentary through spring with movements only slightly exceeding those of winter as indicated by clumping of seasonal centers of activity (Figure 15). Adult female 1757, was monitored during spring 1977 and 1979. 


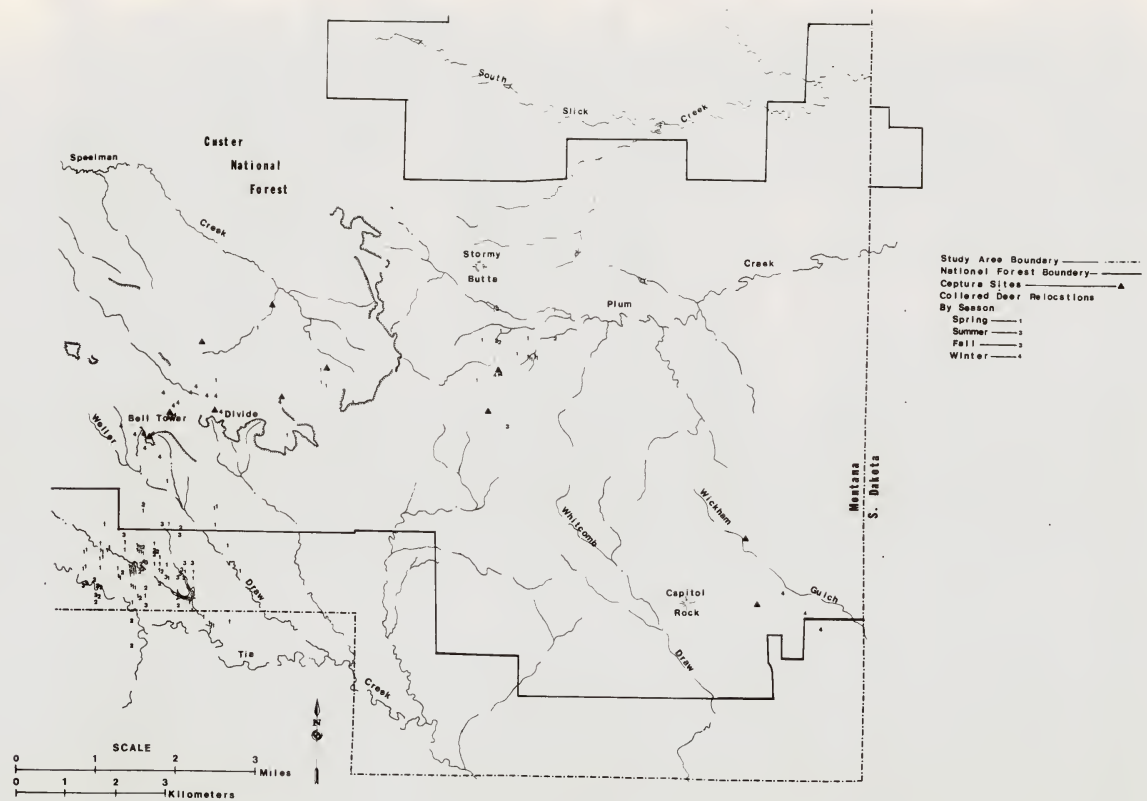

Figure 13. Distribution by season of sightings among 38 individually marked (collared) white-tailed deer from February 1977 through August 1979. 


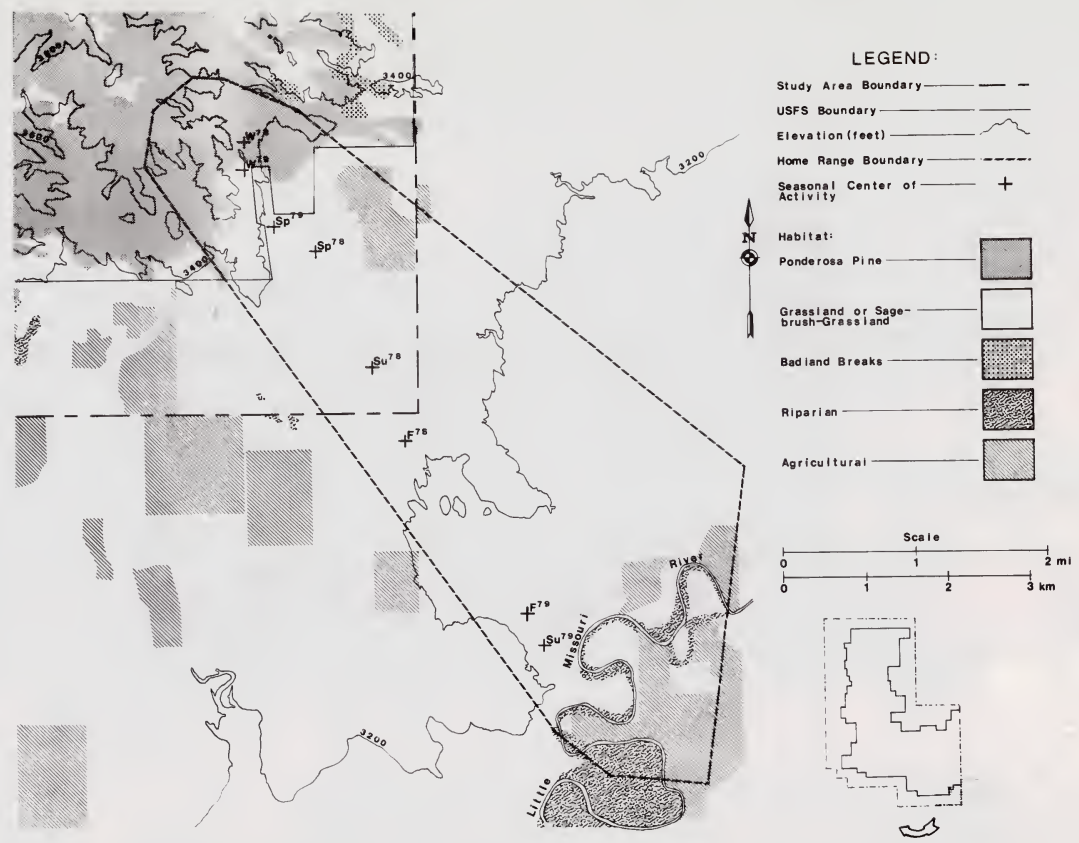

Figure 14. Annual home range and seasonal distribution of a radio-equipped adult female white-tailed deer (1769) from December 1977 through November 1979. 


\section{LEGEND}

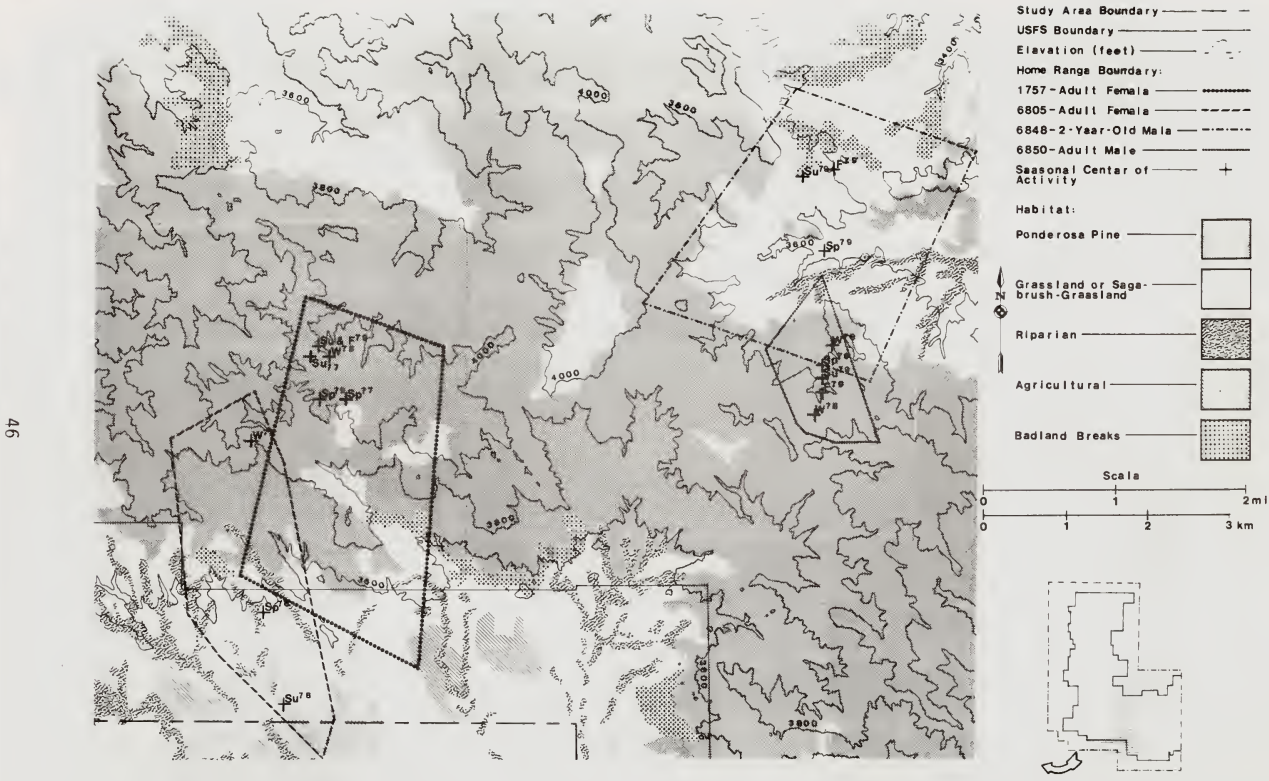

Figure 15. Annual home range and seasonal distribution of 2 adult female and 2 adult male white-tailed deer equipped with radio transmitters in the Long Pines study area. 
Her transmitter had failed during August 1977 and only occasional sightings were obtained from September 1977 through December 1978. She was recaptured and equipped with another transmitter during January 1979. Her diurnal activity during spring 1977 and 1979 occurred primarily in the same side drainage in upper Speelman Creek and overlapped her 1979 winter home range (Fiqure 15). Patterns of activity of radioed deer dispersing from the national forest through April generally reflected movement from winter home ranges during early morning and evening periods and return to winter home ranges during midday. These individuals were often relocated on prairie or agricultural sites, or in nearby riparian sites, during early morning or just prior to darkness. During May several did not return to wintering areas but instead remained off the national forest using deciduous cover in draws dissecting prairie grasslands or agricultural areas for resting cover. All but one were adult females $(1752,1762$, $1769,1772,6805$ and 6844). Two (1762 and 1769) were thought to be travelling to bottomlands of the Little Missouri River to feed during hours of darkness, a distance of 3 to 4 miles $(4.8$ to $6.4 \mathrm{~km})$ from their winter home range in the Long Pines. Both were often observed travelling through sagebrush-grasslands or prairie grasslands toward the Long Pines just prior to sunrise. Adult female 1769 was observed on the riverbottom on one occasion during April 1978 and during late March 1979.

During the last week of April 1979 adult female 6844 moved from the North Tie Creek drainage, where she spent the previous winter and early spring, to the West Short Pines in Harding County, South Dakota, representing a movement of approximately 22 miles $(35.4 \mathrm{~km})$. She remained there through the following summer in an area resembling, both topographically and vegetatively, her wintering area in the Long Pines. An individually marked female oberved with 6844 in both areas, also moved to the West Short Pines.

Spring dispersal of white-tailed deer was partially explained in terms of deer taking advantage of increased availability of forage and foraging areas as indicated by increased use of agricultural areas and qrassland parks during sprinq (Table 3), a period when environmental conditions, such as weather and forage preferences and availability, favored their use. Foliage appearing on trees and shrubs along riparian draws perhaps increased the cover value of such areas as well as providing an additional source of forage. This may have eliminated the need to travel to conifer cover following periods of feeding. Social behavior may also have influenced dispersal of whitetails into less densely populated areas. Kammermeyer and Marchington (1976) described such dispersal during fall as influenced by sexual competition among males during the rut. Dispersal during late spring could possibly be related to social and spatial segregation of adult females as suggested by Harmoning (1976). Hawkins and Klimstra (1970) described the breaking up of primary associations (an adult doe and her fawn(s) from the previous year) during late spring.

Summer - of 8 radioed deer, whose movements were monitored during at least one of three summers, an adult female (1757) and three males 
(6813, 6848, and 6850) exhibited sedentary behavior with summer home ranges overlapping winter home ranges within the national forest with one exception. The exception was a 2-year-old male (6848) who spent the winter of 1978-79 in conifer habitat on the south side of upper Plum Creek and moved approximately 1.5 miles $(2.4 \mathrm{~km})$ to use riparian tree/shrub sites in side drainages of Plum and South Slick Creeks near Stormy Butte during summer 1979. Adult female 1757 spent both the summers of 1977 and 1979 in the same side drainaqe of upper Speelman Creek (Fiqure 15). Whether or not she had a fawn(s) during either summer was not determined.

Four deer, all adult females (1762, 1769, 6805 and 6844), moved from the Long Pines during late spring or during summer. Only in one case (1762) did a summer home range of those deer overlap that of the previous winter. Since seasons were arbitrarily defined, summer home ranges of 1762 and 1769 reflected seasonal migrations from the Long Pines. Adult female 1762 remained near her winter home range throughout 1977, and moved from the Long Pines during early morning or evening hours. Her seasonal movements differed little from those of spring 1977 (Tables 6 and 7). She moved to bottomlands along the Little Missouri River during late July 1978 and remained there through the summer. She was observed with fawns during summer 1977 but not during 1978.

After vacillating between the Long Pines and the Little Missouri River during spring 1978 and 1979, adult female 1769 shifted to the river bottomlands using stands of green ash, cottonwoods or willows (Salix spp.) for resting cover during late July 1978 and late June 1979. She occupied the same section of riverbottom both summers, although centers of activity between years were influenced by a difference of a month in timing (Figure 14). She may have selected that area for giving birth and rearing fawns, since she was not observed accompanied by newborn fawns until having moved to the river, approximately 4.5 miles $(7.2 \mathrm{~km})$ from the Long Pines. She was observed with a single fawn each year. Adult female 6844 spent summer 1979 in the West Short Pines and was accompanied by at least one fawn.

During summer 1978 adult female 6805 confined her summer activity to a sma 11 area (Table 6) on the bottom of Tie Creek (Figure 15) using riparian tree/shrub sites for resting cover and feeding in nearby meadows during twilight periods. She was accompanied by 2 fawns when observed during summer and she died shortly after mid-August.

Summer movements and habitat use by adult females appeared to be larqely influenced by fawning behavior and appeared to stabilize just prior to fawning. Sparrowe and Springer (1970) reported that summer home ranges of white-tailed deer in eastern South Dakota were restricted to a few favored feeding and bedding sites, and the only exceptions they observed were yearling and adult females. Harmoning (1976) reported that availability of forage and social and spatial segregation among females influenced summer dispersal among white-tailed deer. 
Two adult males $\left(2 \frac{1}{2}+\right)$, both occurring in the upper Plum Creek drainage, generally used areas overlapping winter home ranges. Among individually marked antlered males using prairie grasslands and agricultural areas on Tie Creek during summer, 60 percent were yearlings and 2-year-olds, whereas older males accounted for a larger proportion of those observed there during spring.

Fall - More than one radioed animal was available for study only during fall 1979 (Tables 6 and 7). Female 6844 had returned to her winter home range from the West Short Pines just prior to early September 1979. Adult male 6850 , whose age was estimated at $4 \frac{1}{2}+$ years, remained quite sedentary throughout the fall of 1979 (Figure 15), although his home range and movements increased slightly over summer (Tables 6 and 7). Conversely, the $2^{1} \frac{1}{2}$-year-old male (6848) exhibited a pattern of erratic and random wandering, especially during November (Figure 15). Mean distances travelled between consecutive relocations throughout the fall (September-iNovember) and during November only were 0.7 and 1.1 miles $(1.1$ and $1.8 \mathrm{~km})$, respectively.

Whitetails appeared to be dispersed throughout the same areas as during spring and summer (Figure 13). Adult female 1769 remained on the bottomlands of the Little Missouri River into the fall during both 1978 and 1979. A collared adult female was observed with her there on one occasion during 1978 and local residents reported seeing this animal on several occasions along the river during both 1978 and 1979 . One adult male ( $3 \frac{1}{2}+$ years) was taken by a hunter near the Sheep Mountains during fall 1979, approximately 5 miles $(8 \mathrm{~km})$ south of where the animal was captured and marked on the Belltower Divide during late January 1978. He had been last observed on Tie Creek, south of the national forest boundary, during late April 1979. Among observations of collared males $1 \frac{1}{2}+$ years along Tie Creek during fall, 87 percent were vearlings and $2 \frac{1}{2}$-year-olds. Several authors have reported dispersal, or comparatively greater movements, among yearling or $2 \frac{1}{2}$-year-old males, as compared to older males, during fall, likely resulting from sexual competion among males (Kammermeyer and Marchington 1976, Carlsen and Farmes 1957, Downing and McGinnes 1975).

Adult female 1769 returned to the Long Pines from the Little Missouri River during mid-0ctober in 1978 and during mid-November of 1979. It is unknown whether or not hunting pressure had influenced this animal's movement back to the Long Pines. Archery hunting seasons were held in western South Dakota, which includes a portion of the Little Missouri River, either prior to or during the time in which the animal had moved. During 1978 she returned to the Long Pines just prior to the opening of the deer hunting season in southeastern Montana, and in 1979 she returned during the middle of the hunting season. Within the Long Pines, the proportion of relocated radioed whitetails which were actually observed decreased during the hunting season. Adult females were seen 19 and 8 percent of the time they were relocated during September-0ctober and November, respectively. The two males were observed 6 percent of the times they were relocated during September-0ctober but neither was 
observed during November suggesting whitetails were perhaps using denser cover during the hunting season.

\section{Food Habits}

Food habits of white-tailed deer were determined from analysis of rumen contents from 105 individual deer from October 1976 through November 1979. Included were $62,18,18$ and 7 samples from fall, winter, spring and summer, respectively. All but one were obtained within national forest boundaries. Agricultural crops present in samples reflected movement of deer to adjacent private lands to feed. The volume of bait material was deleted from samples taken from deer having died incidental to trapping during winter and early spring.

Browse, forbs and grasses accounted for 71,18 and 9 percent, by volume, of the yearlong diet of white-tailed deer, respectively, although relative abundance of forage classes changed seasonally (Figure 16). The combined use of snowberry, chokecherry, Oregon grape and ponderosa pine accounted for 64 percent of the annual diet. Snowberry and chokecherry were consumed in appreciable quantities during al1 seasons (Table 8) and exhibited the highest average frequencies of 75 and 70 percent, respectively. Oregon grape and ponderosa pine received nearly all their use from late fall through early spring. Use of individual items is summarized during semi-seasonal periods (Table 8 ). Yearlong trends in use among forage classes as well as use of major browse species basically resembles that of white-tailed deer in the Black Hills (Hill 1946).

Fall - Browse, forbs and grasses accounted for 75, 14 and 10 percent of the diet during fall, respectively (Fiqure 16). Snowberry and Oregon grape together accounted for 58 percent of the seasonal diet, while chokecherry and wild plum were used in lesser amounts. Deer increased their use of Oregon grape from early to late fall while decreasing their use of snowberry (Table 8). They consumed very little, if any, ponderosa pine during years that remained relatively snow-free through November. During 1978 , when more than a foot $(30.5 \mathrm{~cm})$ of snow accumulated by the second week of November, pine needles averaged 23 percent of the late fall diet. Oregon grape and snowberry together averaged 32 percent compared to 51 percent for years that remained snow-free. Nearly all late fall samples were obtained from the last week of October through the third week of

Agricultural crops were not represented in 3 samples taken during early fall (September 1 - October 15), but saffloiver (Carthamus tinctorius), alfalfa (Hedicago sativa), barley (Hordeum vulgare) and wheat (Triticum aestivuml occurred in samples taken during late fall. Their combined use accounted for 13 percent of the late fall diet. Other herbaceous species did not individually account for more than 2 percent of the diet during fall (Table 8 ). The more prevalent ones included aster, wild licorice and bluegrasses, presumably Kentucky bluegrass. Deer al so fed on tree moss and mushrooms when available (Table 8). 


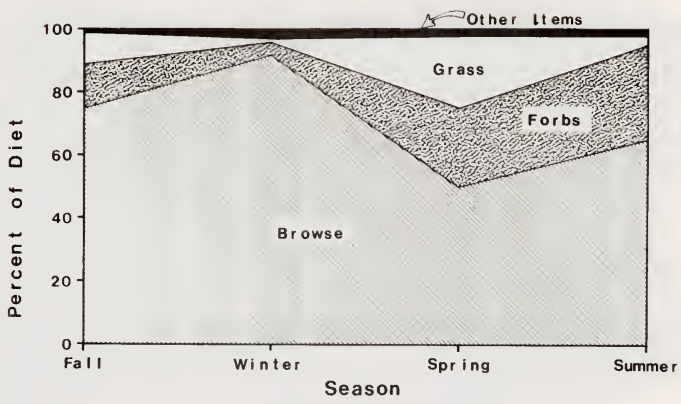

White-tailed Deer

Figure 16. Seasonal use of forage classes by white-tailed deer in the Long Pines study area.

Fall food habit data generally indicated heavy use of ponderosa pinemesic shrub sites, riparian tree/shrub sites and agricultural areas for foraging. Observations from vehicle surveys indicated comparatively heavy use of those areas (Table 3 ). Forty-six percent of fall observations were obtained during evening (after 1600 hours). Data from radioed deer did not indicate use of agricultural areas during fall, perhaps due to the small sample of deer monitored during that season and the time of relocations. Forty-five percent of observations of collared deer occurred in prairie-anricultural areas during fal1, whereas ponderosa pine and riparian habitat accounted for 25 and 27 percent, respectively. Among rumens obtained during late fall, agricultural crops were identified in 32 percent. Such items accounted for only a small portion of the contents of many of these indicating that these deer also fed in other vegetational communities while travelling to or from croplands or hay meadows. Several 
Table 8. Semi-seasonal food habits of white-tailed deer in the Long Pines as determined from analysis of 105 rumen samples from October 1976 through November 1979a.

\begin{tabular}{|c|c|c|c|c|c|c|c|c|}
\hline Taxab & $\begin{array}{l}\text { Early } \\
\text { Fal11 } \\
\text { (3) } \mathrm{C}\end{array}$ & $\begin{array}{l}\text { Late } \\
\text { Fall } \\
\text { (59) }\end{array}$ & $\begin{array}{l}\text { Early } \\
\text { Winter } \\
\text { (12) }\end{array}$ & $\begin{array}{l}\text { Late } \\
\text { Winter } \\
\text { (6) }\end{array}$ & $\begin{array}{l}\text { Early } \\
\text { Spring } \\
(10)\end{array}$ & $\begin{array}{l}\text { Late } \\
\text { Spring } \\
(8)\end{array}$ & $\begin{array}{l}\text { Early } \\
\text { Summer } \\
\text { (3) }\end{array}$ & $\begin{array}{l}\text { Late } \\
\text { Summer } \\
(4)\end{array}$ \\
\hline
\end{tabular}

BROWSE :

\begin{tabular}{|c|c|c|c|c|c|c|c|c|}
\hline & & & & & & & & \\
\hline Amelanchier alnifolia & - & $5 / 1$ & - & - & - & $25 / \mathrm{tr}$ & $33 / \mathrm{tr}$ & - \\
\hline $\begin{array}{l}\text { Arctostaphylos uva-ursi } \\
\text { Artemisia cana }\end{array}$ & - & $\begin{array}{l}5 / \operatorname{tr} \\
2 / \operatorname{tr}\end{array}$ & $\begin{aligned} 17 / 2 \\
8 / 1\end{aligned}$ & - & - & - & - & - \\
\hline Berberis repens & $100 / 4^{d}$ & $78 / 31$ & $\begin{array}{r}8 / 1 \\
67 / 22\end{array}$ & $83 / 24$ & $40 / 16$ & $12 / \mathrm{tr}$ & $\overline{-}$ & $50 \bar{l}$ \\
\hline Crataegus succulenta & - & $29 / 4$ & $17 / 1$ & - & - & 1217 & - & SU/ \\
\hline Juniperus communis & - & $2 / \mathrm{tr}$ & $17 / \mathrm{tr}$ & $17 / 11$ & $10 / \operatorname{tr}$ & $12 / \mathrm{tr}$ & - & - \\
\hline Juniperus scopulorum & - & - & - & 1717 & - & - & - & - \\
\hline Pinus ponderosa & $100 / \operatorname{tr}^{\mathrm{e}}$ & $58 / 5$ & $75 / 40$ & $100 / 40$ & $90 / 43$ & $62 / \operatorname{tr}$ & - & - \\
\hline $\begin{array}{l}\text { Popululus tremuloides } \\
\text { Prunus americana }\end{array}$ & $67 / 10$ & $\begin{array}{l}7 / \operatorname{tr} \\
2 / \operatorname{tr}\end{array}$ & $\begin{array}{l}8 / \operatorname{tr} \\
8 / \operatorname{tr}\end{array}$ & $\begin{array}{ll}33 / 1 \\
17 / 1\end{array}$ & - & $\begin{array}{l}25 / \mathrm{tr} \\
12 / \mathrm{tr}\end{array}$ & - & $\overline{-}$ \\
\hline Prunus virginiana & $67 / 10$ & $37 / 3$ & $67 / 10$ & $67 / 12$ & $60 / 14$ & $\begin{array}{l}12 / \operatorname{tr} \\
62 / 5\end{array}$ & $100 / 14$ & $100 / 24$ \\
\hline Rhus trilobata & - & $8 / \operatorname{tr}$ & $8 / \operatorname{tr}$ & - & $20 / 1$ & $12 / \operatorname{tr}$ & - & - \\
\hline $\begin{array}{l}\text { Rosa spp. } \\
\text { Symphoricarpos spp. }\end{array}$ & $\begin{array}{r}67 / \mathrm{tr} \\
100 / 67\end{array}$ & $49 / 1$ & $33 / \mathrm{tr}$ & $17 / \mathrm{tr}$ & $20 / \mathrm{tr}$ & $50 / 2$ & $100 / 3$ & $75 / 2$ \\
\hline Unidentified Browse & $33 / \mathrm{tr}$ & $\begin{array}{l}89 / 19 \\
34 / 1\end{array}$ & $\begin{array}{l}50 / 17 \\
50 / 4\end{array}$ & $\begin{array}{l}67 / 4 \\
67 / \operatorname{tr}\end{array}$ & $\begin{array}{l}60 / 4 \\
70 / 4\end{array}$ & $\begin{array}{l}62 / 11 \\
37 / \mathrm{tr}\end{array}$ & $\begin{array}{r}100 / 45 \\
67 / 6\end{array}$ & $\begin{array}{l}75 / 30 \\
75 / 5\end{array}$ \\
\hline TOTAL BROWSE & $100 / 85$ & $93 / 65$ & $100 / 91$ & $100 / 94$ & $100 / 82$ & $87 / 19$ & $100 / 68$ & $100 / 62$ \\
\hline BS & & & & & & & & \\
\hline Anemone patens & - & - & - & - & - & $37 / 4$ & $33 / \mathrm{tr}$ & - \\
\hline $\begin{array}{l}\text { Artemisia frigida } \\
\text { Aster spp. }\end{array}$ & $\overline{1}$ & $2 / \mathrm{tr}$ & $8 / \operatorname{tr}$ & $8 / 2$ & $10 / \operatorname{tr}$ & - & - & - \\
\hline $\begin{array}{l}\text { Aster } \mathrm{spp} \text {. } \\
\text { Carthamus tinctorius }\end{array}$ & $33 / \mathrm{tr}$ & $32 / 2$ & $8 / \operatorname{tr}$ & - & - & - & - & - \\
\hline $\begin{array}{l}\text { Carthamus tinctorius } \\
\text { Chrysops is villosa }\end{array}$ & $\overline{-}$ & $7 / 2$ & $\bar{i}$ & $\overline{-}$ & - & - & - & - \\
\hline $\begin{array}{l}\text { Chrysops is villosa } \\
\text { Glycyrrhiza lepidota }\end{array}$ & $33 / 3$ & $\begin{array}{l}12 / 1 \\
27 / 1\end{array}$ & $\begin{array}{l}42 / 1 \\
17 / \operatorname{tr}\end{array}$ & $17 / \mathrm{tr}$ & - & $12 / 4$ & - & - \\
\hline $\begin{array}{l}\text { Glycyrrhiza lepidota } \\
\text { Linum rigidum }\end{array}$ & - & $\begin{aligned} 21 / 1 \\
5 / 2\end{aligned}$ & $\begin{array}{l}17 / \mathrm{tr} \\
-\end{array}$ & 17/ 1 & $\begin{array}{c}10 / 1 \\
-\end{array}$ & - & $33 / \operatorname{tr}$ & $50 / \mathrm{tr}$ \\
\hline Medicago sativa & - & $15 / 1$ & - & - & - & $12 / 10$ & - & $25 \overline{\mathrm{t}} \mathrm{r}$ \\
\hline
\end{tabular}


Table 8. Continued

\begin{tabular}{|c|c|c|c|c|c|c|c|c|}
\hline Taxa & $\begin{array}{l}\text { Early } \\
\text { Fal1 } \\
(3) \\
\end{array}$ & $\begin{array}{l}\text { Late } \\
\text { Fa } 11 \\
(59) \\
\end{array}$ & $\begin{array}{l}\text { Early } \\
\text { Winter } \\
(12) \\
\end{array}$ & $\begin{array}{l}\text { Late } \\
\text { Winter } \\
\text { (6) }\end{array}$ & $\begin{array}{l}\text { Early } \\
\text { Spring } \\
(10)\end{array}$ & $\begin{array}{l}\text { Late } \\
\text { Spring } \\
(8)\end{array}$ & $\begin{array}{l}\text { Early } \\
\text { Summer } \\
(3)\end{array}$ & $\begin{array}{l}\text { Late } \\
\text { Summer } \\
(4)\end{array}$ \\
\hline \multicolumn{9}{|l|}{ FORBS: continued } \\
\hline $\begin{array}{l}\text { Melilotus officinalis } \\
\text { Ratibida columnifera } \\
\text { Taraxicum officinale } \\
\text { Tragopogon dubius } \\
\text { Yucca glauca } \\
\text { Unidentified Forbs }\end{array}$ & $\begin{array}{c}67 / \operatorname{tr} \\
- \\
- \\
- \\
- \\
100 / 10\end{array}$ & $\begin{array}{l}5 / 1 \\
- \\
3 / \operatorname{tr} \\
14 / \operatorname{tr} \\
2 / \operatorname{tr} \\
66 / 7\end{array}$ & $\begin{array}{c}- \\
- \\
8 / \operatorname{tr} \\
8 / 2 \\
58 / 1\end{array}$ & $\begin{array}{c}- \\
- \\
- \\
33 / 1\end{array}$ & $\begin{array}{l}- \\
\overline{-} \\
\overline{-} \\
10 / 1 \\
60 / 4\end{array}$ & $\begin{array}{l}25 / \operatorname{tr} \\
12 / 4 \\
25 / 1 \\
50 / \operatorname{tr} \\
- \\
87 / 21\end{array}$ & $\begin{array}{l}33 \overline{-} 9 \\
\overline{-} \\
33 / \operatorname{tr} \\
\overline{-} \\
67 / 18\end{array}$ & $\begin{array}{c}\overline{-} \\
25 / \mathrm{tr} \\
\overline{-} \\
25 / 16 \\
\overline{-} \\
100 / 17\end{array}$ \\
\hline TOTAL FORBS & $100 / 13$ & $92 / 15$ & $83 / 4$ & $67 / 3$ & $60 / 6$ & $100 / 44$ & $100 / 27$ & $100 / 33$ \\
\hline \multicolumn{9}{|l|}{ GRASSES : } \\
\hline $\begin{array}{l}\text { Agropyron spp. } \\
\text { Hordeum vulgare } \\
\text { Poa spp. } \\
\text { Triticum aestivum } \\
\text { Unidentified Grasses }\end{array}$ & $\begin{array}{ll}- \\
\overline{3} / \overline{1} \\
\overline{-} \\
67 \overline{1}\end{array}$ & $\begin{array}{rr}8 / & 1 \\
17 / & 6 \\
20 / & 2 \\
8 / 4 \\
64 / 4\end{array}$ & $\begin{array}{c}- \\
\overline{-} \\
42 \overline{1}\end{array}$ & $\begin{array}{l}- \\
- \\
50 / 1\end{array}$ & $\begin{aligned} 10 / 2 & \\
20 / & 3 \\
-\overline{1} & 2\end{aligned}$ & $\begin{array}{l}25 / 1 \\
- \\
75 / 22 \\
- \\
87 / 12\end{array}$ & $\begin{array}{c}- \\
\overline{-} \\
\overline{3}\end{array}$ & $\begin{array}{l}- \\
- \\
- \\
\overline{-}\end{array}$ \\
\hline TOTAL GRASSES & $100 / 2$ & $86 / 17$ & $42 / 1$ & $50 / 1$ & $70 / 12$ & $100 / 35$ & $33 / 2$ & $75 / 3$ \\
\hline \multicolumn{9}{|l|}{ OTHER } \\
\hline $\begin{array}{l}\text { Tree Moss } \\
\text { Mushrooms } \\
\text { Bracket Funqi }\end{array}$ & $\begin{array}{c}33 / \operatorname{tr} \\
- \\
-\end{array}$ & $\begin{array}{l}29 / 2 \\
14 / t r \\
2 / t r\end{array}$ & $\begin{array}{c}25 / 1 \\
- \\
8 / \operatorname{tr}\end{array}$ & $\begin{array}{l}83 / 1 \\
-\overline{1} \\
50 / 1\end{array}$ & $\begin{array}{c}30 ; \\
- \\
-\end{array}$ & $\begin{array}{c}12 / t r \\
- \\
-\end{array}$ & $33 / 1$ & $\begin{array}{c}50 / \operatorname{tr} \\
25 / \operatorname{tr} \\
-\end{array}$ \\
\hline
\end{tabular}

a All samples for early and late summer and early fall were obtained during 1977.

b Includes only those taxa with an average volume of 0.5 percent in at least one semi-seasonal period.

c Sample size.

d Frequency (percent occurrence among samples)/average percent volume.

e $t r$ - trace ( a value less than 0.5 percent). 
authors reported selection of aqricultural areas during fall, and particularly their increased use during nocturnal periods (Harmoning 1976, Kammermeyer and Marchinqton 1977, Larson et a1. 1978). Data from marked deer suggested that individuals travelling to and using such areas included those whose wintering areas occurred only a short distance from the forest boundary.

(Uinter - Browse was used most heavily during winter (Figure 16). Relative use of major winter browse species, which included ponderosa pine, Oreqon grape, chokecherry and snowberry, appeared related to differences in availability of Oregon grape and snowberry imposed by depth and temporal differences in snow cover between years. Nine, 6 and 3 samples were obtained during winter 1976-77, 1977-78 and January
1979 , respectively.

Oregon grape accounted for 43 percent of the winter diet during 1976-77, the mildest winter, and 4 percent and in trace amounts during 1977-78 and January 1979, respectively. Snowberry accounted for 18 percent of the diet during 1976-77, occurred only in trace amounts during 1977-78 and was not present among the January 1979 samples. Chokecherry constituted 13 percent during both of the first two winters but was not present in samples of January 1979. Conversely, ponderosa pine accounted for 12, 53 and 98 percent of samples for the three respective periods. Kamps (1969) and Martinka (1970) reported increased use of conifers by white-tailed deer when deep snow made low-growing shrubs unavailable. Common juniper (Juniperus communis) occurred in late winter samples in appreciable quantities (Table 8). Bark from pine occurred in small quantities in winter samples and its use was associated with that of tree moss, which accounted for one percent of the winter diet.

Forbs accounted for a smaller portion of the diet during winter as compared to other seasons (Fiqure 16). A variety of species occurred in winter samples, but no sinqle species averaged more than one percent of the seasonal diet (Table 8). Winter food habits supported the conclusion that patterns of winter activity of white-tailed deer in the Long Pines were restricted to conifer habitat, particularly ponderosa
pine-mesic shrub sites.

Spring - Forage use during early spring did not change appreciably from that of late winter, neither qualitatively nor quantitatively (Table 8). All spring samples were obtained during 1977 and 1978. pine remained the leading item during early spring 1978 accounting for 48 percent of the average volume but accounting for only 32 percent during the same period of 1977. Oregon grape accounted for 42 and 5 percent of the early spring diet during 1977 and 1978, respectively. Use of chokecherry increased from 6 to 18 percent from late winter to early spring 1978. Nearly all of this consisted of woody stem tissue of perhaps second to third year growth, suggesting that annual leader growth and terminal buds, the principal portions of that species used during late fall and early winter, had been depleted. Woody tissue probably had less nutritional value than terminal stems and buds (Bailey 1967). 
Forage availability and preferences of deer changed from late March to early April when browse received its lowest yearly use and forbs and grasses received their greatest (Table 8 and Figure 16). Among browse used during late spring, leaves from snowberry and chokecherry were used most prevalently. Pasque flower (Anemone patens), which occurred in 3 of 8 late spring samples, was one of the more commonily used forbs. Dandelion (Taraxicum officinale) and bluegrasses, which were presumabiy dominated by Kentucky bluegrass, were also identified among several late spring samples. During that period 33 percent of the rumen contents consisted of unidentified grasses and forbs. Agricultural crops were identified in only one of 8 samples and consisted of alfalfa (Table 8 ). The low incidence of use of agricultural crops perhaps reflected the small number of animals sampled during the period and the location within the study area from which they were taken.

The shift from browse to herbaceous forage by whitetails during spring represented the only major annual change (Figure 16). This shift reflected use of a broader spectrum of their habitat as compared to winter. Use of pasque flower, which occurred only on timbered sites and emerged (Appendix Table 3) almost immediately following recession of snow cover, indicated that deer continued to feed in pine habitat. Occurrence of dandelion and bluegrasses in the late spring diet supported observational data which indicated comparatively heavy use of grassland parks, ponderosa pine and riparian sites (Table 3 ).

Summer - Whitetails increased their use of browse from spring to summer, while decreasing their consumption of grasses (Figure 16). The level of usage among forbs decreased only slightly. All samples for this season were taken during 1977 (Table 8) which received below normal rainfall (Table 1). Leaves from snowberry and chokecherry accounted for 56 percent of the seasonal diet. While constituting only two percent of the summer diet, wild rose was identified among six of seven samples taken during the period. Forbs occurred in greater proportion than browse ( 89 to 12 percent) in a sample from an animal killed by an automobile along the floodplain of Tie Creek south of the national forest during mid-Auqust 1977. Common salsify (Tragopogon dubius) constituted 66 percent, by volume, of that sample. Seventeen percent of the average volume during summer consisted of unidentified forbs. I would expect greater use of forbs by whitetails during growing seasons receiving greater amounts of spring and early summer precipitation than
received in 1977 .

Population Characteristics

\section{Physical Condition}

Whole and field-dressed weights were recorded for 23 whitetails taken during all months except October and November. Field-dressed weights (Table 9) for specimens of all age and sex classes were below the average for white-tailed deer weighed at check stations throughout Montana from 1948-63 (Mackie 1964). Dressed weights from the entire Long Pines sample 
averaged 30 percent lower than statewide averages, although seven deer taken during September, December and January averaged only 26 percent 1 ower than statewide averages. Smallest departures were observed among fawns and the greatest among males $2 \frac{1}{2}$ years and older (Table 9). Dressed weights of whitetails from bottomlands of the Missouri River (Allen 1968) and the Snowy Mountains (Kamps 1969) were also lower than statewide averages. Dressed weights of whitetails reported by Mundinger (1979) for the Swan Valley in northwestern Montana were higher than the statewide averages (Mackie 1964).

Dressed weights of al1 23 deer averaged 69 percent of whole weights, varying from 64 to 75 percent. Factors that may influence this ratio include condition, blood loss and the amount of material in the paunch (nuimby and Johnson 1951). The ratio did not change seasonally from winter through summer, although two field-dressed carcasses averaged 66 percent during September. Indices for fawns and males $2 \frac{1}{2}$ years and older were 71 and 70 percent, respectively, as compared to 68 percent for females $2 \frac{1}{2}$ and older. Robinette et al. (1977) reported that lactating female mule deer had lower dressing indices than other females. This may partially explain differences between sex and aqe classes. Kamps (1969) reported an average dressing index of 71 percent for whitetails in the Snowy Mountains.

A kidney fat index was calculated for each of 71 deer from December 1976 through November 1979. The sample included 31, 17, 17 and 6 specimens from fall, winter, spring and summer, respectively. All but two of the fall samples were taken from hunter-killed deer during late October through November. Samples for summer and early fall (June 1-October 15) were obtained only during 1977. Average indices for all years indicated a sharp decline in physical condition from late fall to early winter (Fiqure 17) generally coinciding with the onset of cold weather. During late fall the highest index was observed during 1978, a period which followed the wettest growing season during the study (Table 1). The spring-summer periods of both 1977 and 1979 were abnormally dry. Yearly indices during late fall appeared directly related to rainfall during the previous spring and summer perhaps as it influenced the availability of forbs. An increase in average indices from early to late winter (Fiqure 17), which was observed during all years, could not be readily explained. Physical condition of whitetails declined from late winter through late spring. This decline occurred about 6 weeks earlier during the harsh winter of 1978 than during the comparatively mild late winter conditions in 1977. A similar yearly trend in physical condition of white-tailed deer was reported by Allen (1968). Ransom (1965) reported that kidney fat indices most reliably reflect physical condition when at or above 30 percent. Most indices calculated for late spring and early summer were below 30 percent.

Yearly trends in physical condition, as determined from kidney fat indices, varied between sex and age classes (Table 10). During fall highest indices were observed among males $2 \frac{1}{2}$ years and older followed by yearling males, adult females $\left(2 \frac{1}{2}+\right)$ and yearling females, respectively, while lowest indices were observed among fawns. During fall indices among adult females $\left(2 \frac{1}{2}+\right)$ were more variable than among other sex and age classes. 
Table 9. Whole and field-dressed weights of 23 white-tailed deer collected in the Long Pines from December 1976 through March 1978 and departures, by age and sex class from state-wide averages.

\begin{tabular}{|c|c|c|c|c|c|}
\hline $\begin{array}{l}\text { Month of } \\
\text { Collection }\end{array}$ & Sex & $\begin{array}{c}\text { Assigned } \\
\text { Age }\end{array}$ & $\begin{array}{l}\text { Whole } \\
\text { Weight }\end{array}$ & $\begin{array}{l}\text { Field- } \\
\text { Dressed } \\
\text { Weight }\end{array}$ & $\begin{array}{l}\text { Departure } \\
\text { from } \\
\text { Statewide }\end{array}$ \\
\hline $\begin{array}{l}\text { December } \\
\text { January } \\
\text { January } \\
\text { January } \\
\text { January } \\
\text { February } \\
\text { February } \\
\text { March } \\
\text { March } \\
\text { March } \\
\text { March } \\
\text { Apri1 } \\
\text { Apri1 } \\
\text { May } \\
\text { May } \\
\text { June } \\
\text { June } \\
\text { July } \\
\text { July } \\
\text { Auqust } \\
\text { Auqust } \\
\text { September } \\
\text { September }\end{array}$ & $\begin{array}{l}F \\
F \\
M \\
M \\
F \\
F \\
F \\
F \\
F \\
F \\
M \\
F \\
F \\
M \\
F \\
M \\
F \\
M \\
F \\
F \\
F \\
M \\
F\end{array}$ & $\begin{array}{l}2 \frac{1}{2}-4 \frac{1}{2} \mathrm{C} \\
\frac{1}{2} \\
1 \frac{1}{2} \\
4 \frac{1}{2} \\
5 \frac{1}{2} \\
10 \frac{1}{2} \\
4 \frac{1}{2} \\
2 \frac{1}{2}-4 \frac{1}{2} \\
2 \frac{1}{2}-4 \frac{1}{2} \\
3 \frac{1}{2} \\
2 \frac{1}{2} \\
2 \frac{1}{2}-4 \frac{1}{2} \\
4 \frac{1}{2} \\
\frac{1}{2} \\
2 \frac{1}{2}-4 \frac{1}{2} \\
2 \frac{1}{2} \\
1 \frac{1}{2} \\
2 \frac{1}{2} \\
3 \frac{1}{2} \\
4 \frac{1}{2} \\
2 \frac{1}{2}-4 \frac{1}{2} \\
1 \frac{1}{2} \\
2 \frac{1}{2}\end{array}$ & $\begin{array}{c}125(276)^{\mathrm{b}} \\
65(143) \\
100(220) \\
135(298) \\
130(287) \\
100(220) \\
108(238) \\
95(209) \\
90(209) \\
80(176) \\
115(254) \\
96(212) \\
121(267) \\
75(165) \\
125(276) \\
95(209) \\
70(154) \\
95(209) \\
115(254) \\
115(254) \\
98(216) \\
98(216) \\
120(265)\end{array}$ & $\begin{array}{l}80(176) \\
49(108) \\
70(154) \\
95(209) \\
85(187) \\
70(154) \\
73(161) \\
68(150) \\
64(141) \\
55(121) \\
80(176) \\
64(141) \\
81(179) \\
51(112) \\
85(187) \\
65(143) \\
50(110) \\
68(150) \\
80(176) \\
75(165) \\
65(143) \\
65(143) \\
80(176)\end{array}$ & $\begin{array}{l}-23 \% \\
-10 \% \\
-30 \% \\
-43 \% \\
-19 \% \\
-36 \% \\
-30 \% \\
-33 \% \\
-37 \% \\
-48 \% \\
-38 \% \\
-37 \% \\
-23 \% \\
-7 \% \\
-16 \% \\
-50 \% \\
-47 \% \\
-48 \% \\
-24 \% \\
-29 \% \\
-36 \% \\
-35 \% \\
-20 \%\end{array}$ \\
\hline
\end{tabular}

\footnotetext{
a From Mackie (1964) statewide averages for 1948-63.

b Weights expressed in pounds $(\mathrm{kg})$.

c Includes rough field estimate of age by wear on mandibular teeth $\left(2 \frac{1}{2}-4 \frac{1}{2}\right)$.

d June 1 cutoff date - animals advanced one age class.
} 


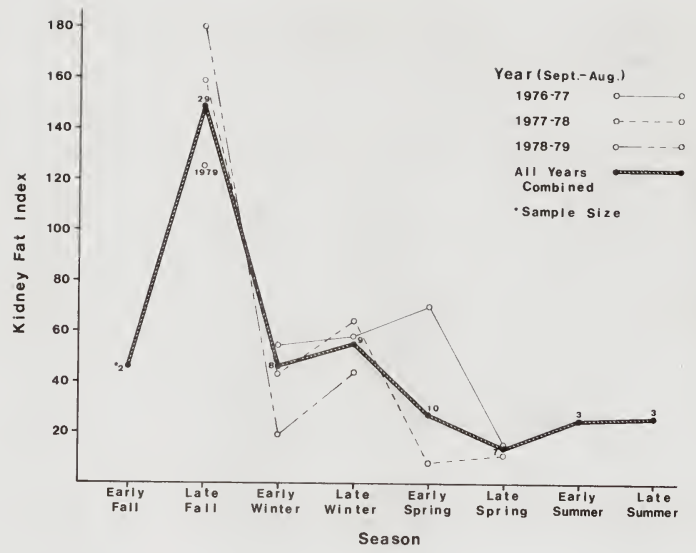

$r$ gure 17. Semi-seasonal trends in physical condition of white-tailed deer in the Long Pines study area determined from kidney fat indices from December 1976 - November 1979.

For example, indices varied from 17 to 307 percent among females sampled during fall 1977 and 38 to 155 percent during 1979. Indices among adult males varied from 114 to 267 percent during fall of all years combined. Mobilization of kidney fat occurred more abruptly among adult males from winter through spring than among adult females, yearlings and fawns (Table 10). It appeared that deer of all sex and age classes were in peak physical condition during late fall prior to the onset of the rut, and in their poorest condition during late spring just prior to fawning.

Swenson and Knapp (1979) analyzed condition of whitetails in southeastern Montana using diastemal and antler measurements from hunter-killed yearling males during 1978. Indices from diastemal length, main beam length, main beam circumference and number of points were consistently lower among specimens taken from the Long Pines compared to those from along the Yellowstone River and in other areas of southeastern Montana. They concluded that the lower indices among the sample from the Long Pines reflected their dietary level during the harsh winter of 1977-78. Since fawns did not accumulate abundant reserves of fat, as compared to older deer, retarded growth and reduction in antler size may have resulted from extended periods of cold air temperatures combined with limited selection 
Table 10. Seasonal kidney fat indices of white-tailed deer by sex and age class as determined from 71 specimens obtained from December 1976 through November 1979.

\begin{tabular}{|c|c|c|c|c|}
\hline $\begin{array}{l}\text { Sex and } \\
\text { Age Class }\end{array}$ & $\begin{array}{r}\text { Fal1 } \\
31 a \\
\end{array}$ & $\begin{array}{c}\text { Winter } \\
17 \\
\end{array}$ & $\begin{array}{c}\text { Spring } \\
17 \\
\end{array}$ & $\begin{array}{c}\text { Summer } \\
6 \\
\end{array}$ \\
\hline $\begin{array}{c}\text { Adults } 2 \frac{1}{2}+ \\
\text { Females } \\
\text { Males }\end{array}$ & $\begin{array}{l}115(8)^{b} \\
188(10)^{b}\end{array}$ & $\begin{array}{r}59(12) \\
8(2)\end{array}$ & $\begin{array}{l}28(11) \\
11(2)\end{array}$ & $\begin{array}{l}23(3) \\
26(2)\end{array}$ \\
\hline $\begin{array}{c}\text { Yearlings: } \\
\text { Females } \\
\text { Males }\end{array}$ & $\begin{array}{l}111(1) \\
184(6)\end{array}$ & $\left.43^{-\mathrm{C}} 1\right)$ & $\begin{array}{l}8(2) \\
-\end{array}$ & $22(1)$ \\
\hline $\begin{array}{c}\text { Fawns: } \\
\text { Females } \\
\text { Males }\end{array}$ & $\begin{array}{l}55(4) \\
84(2)\end{array}$ & $49(2)$ & $\begin{array}{l}9(1) \\
9(1)\end{array}$ & - \\
\hline
\end{tabular}

a Seasonal sample size.

b Average kidney fat index (number sampled).

c No data available

of forage due to snow depth. Four specimens from the Long Pines during 1978 were all "spikes."

\section{Prenatal Production}

Reproductive tracts were examined from 25 female white-tailed deer from December through May 1976-77 and 1977-78 and from three during January 1979. The sample included 3 fawns, 2 yearlings, 18 from $2 \frac{1}{2}$ to $7 \frac{1}{2}$ years and 5 that were $8 \frac{1}{2}$ years or older. Evidence of pregnancy was not observed among the fawns, and only one of 2 yearlings was pregnant (Table 11). Among 23 adults $2 \frac{1}{2}$ years and older, 21 (91 percent) were pregnant. One of the nonpregnant females, whose age was estimated at $2 \frac{1}{2}-4 \frac{1}{2}$ years, had ovulated as indicated by the presence of one corpora lutea. She may have been in a second estrus cycle when she was killed during late December 1976 since an adult male was observed following her, but she was treated among the sample as an unsuccessful breeder. The other nonpregnant adult was taken during early December 1976. Her age was estimated at $10 \frac{1}{2}+$ years, she appeared to be in extremely poor physical condition, and no evidence of ovulation was observed.

The pregnant yearling bore a single fetus whereas nearly two-thirds of the older females bore twins (Table 11). Two cases of triplets were observed in the sample of females $2 \frac{1}{2}-7 \frac{1}{2}$ years. A ratio of single, twin and triplet pregnancies among females $2 \frac{1}{2}$ years and older was 2.5:6.5:1 
Table 11. Prenatal productivity of white-tailed deer determined from analysis of reproductive tracts of 28 females taken during December-May 1976-77 and 1977-78 and during January 1979.

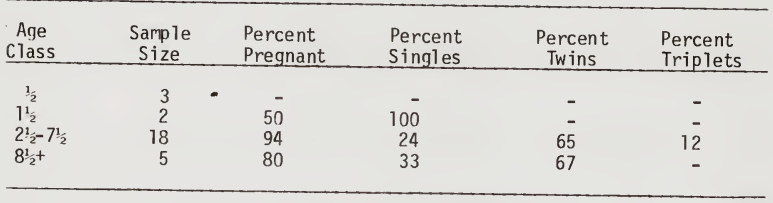

Yearly trends for females $2 \frac{1}{2}+$ years $b$

\begin{tabular}{lccccc} 
Year & Fetuses:Doe & $\begin{array}{c}\text { Fetuses: } \\
\text { Pregnant Doe }\end{array}$ & $\begin{array}{c}\text { Ovulation } \\
\text { Rate }\end{array}$ & $\begin{array}{c}\text { Fetal Se } \\
\text { Ratio (M }\end{array}$ \\
\hline $1976-77$ & $(9)$ & 1.4 & 1.9 & 1.9 & 6.0 \\
$1977-78$ & $(10)$ & 1.6 & 1.6 & 1.6 & 1.8 \\
A11 years $(21)^{d}$ & 1.6 & 1.8 & 1.8 & 3.0 \\
\hline
\end{tabular}

a Sample included 24 females from which the number of fetuses was determined.

b Sample included 21 adult females from which numbers of corpora lutea and fetuses were determined.

c From 16 females, including one yearling, taken during December-May periods of 1976-77 and 1977-78 only in which sex of fetuses was determined.

d Except for the fetal sex ratio, this sample also included two adult females taken during January 1979. 
which approximated a ratio reported by Morton and Cheatum (1946) on comparatively good range in New York. The incidence of multiple pregnancies among adult females was higher than that reported by Teer et al. (1965) for central Texas. Allen (1968) reported a higher incidence of twinning among females along the Missouri River than was observed in the Long Pines. Pac (1978) reported 68 percent of females $2^{1}{ }_{2}$ and older from a sample obtained east of the Continental Divide in Montana, including those from the Long Pines, carried twins.

Two pregnant adult females, from which both ovaries were not recovered or number of fetuses was undetermined due to early stage of pregnancy, were omitted from the sample evaluating fetal and ovulation rates. One bore three fetuses and the other ovulated three ova. It was probable that both had ovulated three ova and would have carried three fetuses since the rate of ova loss (Ransom 1967) among other females in the sample was zero and since the incidence of monozygotic twinning has been reported to be low (Teer et a1. 1965, Barron and Harwell 1973). With inclusion of data from those two females based on the above assumptions, ovulation rates would have been $2.0,1.7$ and 1.9 during 1976-77, 1977-78 and all years combined, respectively. This compared to $1.9,1.6$ and 1.8 among the sample in Table 11 during the respective periods. In any event, fetal and ovulation rates among females $2 \frac{1}{2}$ years and older from the Long Pines occurred on the high side of the range of values reported for this species by Teer et a1. (1965), Ransom (1967), Barrown and Harwell (1973) and were comparable to those reported by Mundinger (1979) in the Swan Valley and Pac (1978) for all of Montana. However, fetal and ovulation rates for the Long Pines were lower than those reported by Allen (1968) for bottomlands of the Missouri River.

Julander et al. (1961) reported a direct relationship between quality of summer range and breeding potential of mule deer. Through experimentation Verme $(1965,1969)$ suggested that nutrition just prior to breeding greatly influenced production in white-tailed deer, particularly among yearlings. Kidney fat indices (Figure 17 and Table 10) indicated a comparatively high level of nutrition in forage used during summer and fall since kidney fat rapidly accumulated during that period, particularly during fall. Browse used during summer and early fall consisted almost entirely of foliage as opposed to abundant quantities of stem tissue during other periods. This, combined with usaqe of forbs, perhaps constituted a highly nutritious diet during the growing season. The lower ovulation rate observed during 1977-78 (Table 11) perhaps resulted from a comparatively low abundance of forbs, particularly on upland sites, during an abnormally dry growing season in 1977 (Table 1). Variability in kidney fat indices among adult females suggested productivity may have varied between segments of the population: those that dispersed into riparian and prairie-agricultural areas during spring and summer as opposed to those that remained in the uplands on the national forest. Breeding potential of white-tailed females $2 \frac{1}{2}$ years and older, in terms of fetal and ovulation rates and rate of multiple births (Table 11), approached that which Verme (1965) reported for similar age classes on a high nutritional plane prior to breeding. This suggested that summer range conditions throughout the period of study were adequate enough to maintain a comparatively high breeding potential among females $2 \frac{1}{2}$ and older. 
Sex was determined for 28 fetuses from 16 females, including one yearling, whose gestation was estimated at 65 or more days (Cheatum and Morton 1946). Short (1970) reported that sex of whitetail fetuses is externally evident at 58 days. A preponderance of male fetuses was observed during both 1977 and 1978 (late January through May) and a ratio of males to females for both years combined was 3:1 (Table 11). Verme (1965) reported that adult females on a low nutritional diet prior to breeding produced a preponderance of males. Verme (1969) bel ieved this was a natural phenomenon, and when coupled with limited production, contributes to self regulation of a population by depressing the herd's annual increment when range carrying capacity is seriously deteriorating. This conflicted with ovulation and fetal rates which did not suggest limited potential. This phenomenon could not be explained on the bas is of summer and fall nutrition but perhaps could be related to the effects that social and spatial relationships, as imposed by population density, exerted on the physiology of reproduction.

Thirty-two fetuses were aned from an embryonic growth curve using crown-rump and forehead-rump measurements. Assuming that fetal growth rates were similar to those observed by Cheatum and Morton (1976), 94 percent of 18 females had been bred between November 11 and December 10 from data taken during all years. Assuming an average gestation period of 201 days for white-tailed deer (Severinghaus and Cheatum 1956), those fawns would have been dropped between May 31 and June 29 . The data indicated that two-thirds of the entire sample had bred between November 2l to December 10. Peak breeding and fawning dates were estimated to occur on November 25 and June 14 , respectively.

\section{Postnatal Production}

The best estimates of annual postnatal production were obtained during late fall (October 16-November 30), a period when all sex and age ratios were most consistent between years (Table 12). It was assumed that fawns were about as observable as adult females during that period. Downing et al. (1977) reported that all sex and age classes were more equally observable during November compared to other periods. Fawn:doe ratios either approached or slightly exceeded 100:100 females $1_{\frac{1}{2}}$ and older from 1976-79. These were much higher than early winter ratios observed by Allen (1968) and Hamlin (1979) along bottomlands of the Missouri River or by Mundinger (1979) for the Swan Valley. This indicated that white-tailed deer in the Long Pines realized a greater proportion of their breeding potential, at least through fall, than did whitetails in portions of Montana where both pre- and postnatal data were available for comparison.

Seventy-five percent of single or pairs of adult females $1 \frac{1}{2}$ and 01 der, observed during fall 1976-1979, were accompanied by one or more fawns (Table 13). Yearling females, ass umed to be nonproducers, hypothetically accounted for nearly 25 percent of the segment including yearling and older females during 1978, which was a year of comparatively low recruitment. No cases of triplets were confirmed during the four years, 
Table 12. Population structure of white-tailed deer in the Long Pines study area from late summer through spring as determined from vehicle route surveys.

\begin{tabular}{|c|c|c|c|c|c|c|}
\hline Season & $\begin{array}{l}\text { Total } \\
\text { Classi- } \\
\text { fied } \\
\end{array}$ & $\begin{array}{l}\text { Fawns: } \\
100 \\
\text { Does } 1 \frac{1}{2}+\end{array}$ & $\begin{array}{l}\text { Fawns: } \\
100 \\
\text { Adults } 1 \frac{1}{2}+\end{array}$ & $\begin{array}{l}\text { Bucks: } \\
100 \\
\text { Does } \quad 1 \frac{1}{2}+\end{array}$ & $\begin{array}{c}\text { Percent } \\
\text { Fawns }\end{array}$ & $\begin{array}{l}\text { Percent } \\
\text { Yrlg. } \\
\text { Bucks } \\
\end{array}$ \\
\hline \multicolumn{7}{|c|}{ Late Summer } \\
\hline 1977 & 116 & 64 & 49 & 32 & 33 & 9 \\
\hline 1978 & 74 & 53 & 32 & 65 & 24 & 1 \\
\hline 1979 & 78 & 77 & 44 & 58 & 31 & 5 \\
\hline \multicolumn{7}{|l|}{ Early Fall } \\
\hline 1977 & 230 & 94 & 64 & 41 & 39 & 9 \\
\hline 1978 & 85 & 145 & 112 & 29 & 53 & 5 \\
\hline \multicolumn{7}{|l|}{ Late Fall } \\
\hline $1976^{*}$ & 81 & 89 & 65 & 36 & 40 & 6 \\
\hline 1977 & 128 & 107 & 88 & 21 & 47 & 6 \\
\hline 1978 & 72 & 100 & 67 & 48 & 40 & 4 \\
\hline 1979* & 63 & 111 & 85 & 31 & 46 & 8 \\
\hline \multicolumn{7}{|l|}{ Winter } \\
\hline $1976-77$ & 180 & - & 80 & - & 44 & - \\
\hline $1977-78$ & 119 & - & 65 & - & 39 & - \\
\hline 1978-79 & 32 & - & 60 & - & 37 & - \\
\hline \multicolumn{7}{|l|}{ Spring } \\
\hline 1977 & 341 & - & 65 & - & 40 & - \\
\hline 1978 & 131 & - & 46 & - & 31 & - \\
\hline 1979 & 127 & - & 46 & - & 31 & - \\
\hline
\end{tabular}

* Late fall samples also included early fall observations.

Tab7e 13. The proportion of females $1 \frac{1}{2}$ years and older that were accompanied by 0,1 or 2 fawns during fall of 1976-79.

\begin{tabular}{lccccc}
$\begin{array}{l}\text { Tumber of } \\
\text { Fawns }\end{array}$ & $\begin{array}{l}1976 \\
(26)^{\mathrm{a}}\end{array}$ & $\begin{array}{c}1977 \\
(117)\end{array}$ & $\begin{array}{c}1978 \\
(51)\end{array}$ & $\begin{array}{c}1979 \\
(26)\end{array}$ & $\begin{array}{c}\text { Average } \\
(214)\end{array}$ \\
\hline 0 & $15^{\mathrm{b}}$ & 28 & 27 & 30 & 25 \\
1 & 62 & 39 & 39 & 35 & 44 \\
2 & 23 & 33 & 33 & 35 & 31 \\
\hline \hline & & & & \\
\hline a (sample size) & & & & \\
b Percent of sample. & & &
\end{tabular}


al though cases where 3 or more fawns were observed within a single group may have included a set of triplets. The data summarized in Table 12 suggested that mortality of fawns through summer and into fall was low and that the number of females conceiving but not successfully rearing fawn(s) may also have been quite low. Therefore postnatal mortality was estimated from the difference among fetal rates of late winter and early spring of 1977 and 1978 (Table 11) to fawning rates among producing does that following fall. The calculated postnatal mortality, or fetal loss rates, for both years combined was 19 percent but did not account for differential breeding potential between 2 year-olds, that would have bred as yearlings, and older females perhaps placing this figure as an upper limit. A lower breeding potential among yearling females has been documented (Teer et a 1. 1965, Ransom 1967, Barron and Harwel1 1973). Verme (1969) reported, from experimentation on penned white-tailed deer, that yearlings are more sensitive to nutritional level than prime age females in terms of breeding potential. Ransom (1967) estimated still births and postnatal losses ranging from 20 to 50 percent in Manitoba following an average winter. In light of relatively high fawn:doe ratios during fall and the relatively small proportion of non-producing females in the Long Pines (Table 12 and 13), it was unl ikely that fetal loss in the Long Pines occurred within that range during 1977 and 1978. It is noteworthy to mention that production, at least among prime age females, was high in 7 ight of having undergone a relatively harsh winter in 1977-78.

\section{Population Trends}

Early winter population estimates during 1977-78 and 1978-79 from Caughley's (1977) formula, as explained in Table 14, were considered minimal since it was assumed that an absolute total count of mule deer was not achieved during early winter census flights. Differences in habitat preference between the species was assumed to lend itself to further underestimating total numbers of white-tailed deer on the study area during early winter. A ratio of white-tailed:mule deer, as determined from vehicle surveys, was obtained from spring through fall 1977 but only during summer and fall 1978 since a suspected epizootic of hemorrhagic disease (EHD) was thought to have claimed white-tailed deer in greater proportion than mule deer during late summer and early fall 1978. Samples of blood serum were taken from 16 and 18 specimens of white-tailed and mule deer, respectively, from the Long Pines and screened for neutralizing antibody for EHD virus. None of the white-tailed deer possessed the antibody, whereas 14 of the samples from mule deer were positive (Feldner 1980). This suggested the EHD virus was particularly lethal to white-tailed deer. Hoff et al. (1973) reported similar findings. The EHD virus was isolated from a white-tailed deer in Rosebud County during summer 1978 (Feldner 1980).

A model (Table 14), including estimated total numbers, composition by sex and age, mortality and natality, was derived from population estimates of early winter 1977-78 and 1978-79. Composition by sex and age were estimated from ratios observed within the population, from a sample of deer trapped during winter 1977-78, from samples of hunter-killed deer checked in the field during 1977 and 1978, and from deer that died during late winter and early spring 1978 (Tables 12, 15, 16 and 17). Total fall numbers were estimated using numbers of deer harvested from return of questionnaires by parties hunting in the Long Pines during 1976-79. It 
Table 14. A model of population size, composition and turnover of white-tailed deer in the Long Pines from fal1 1977 through early winter 1978-79.

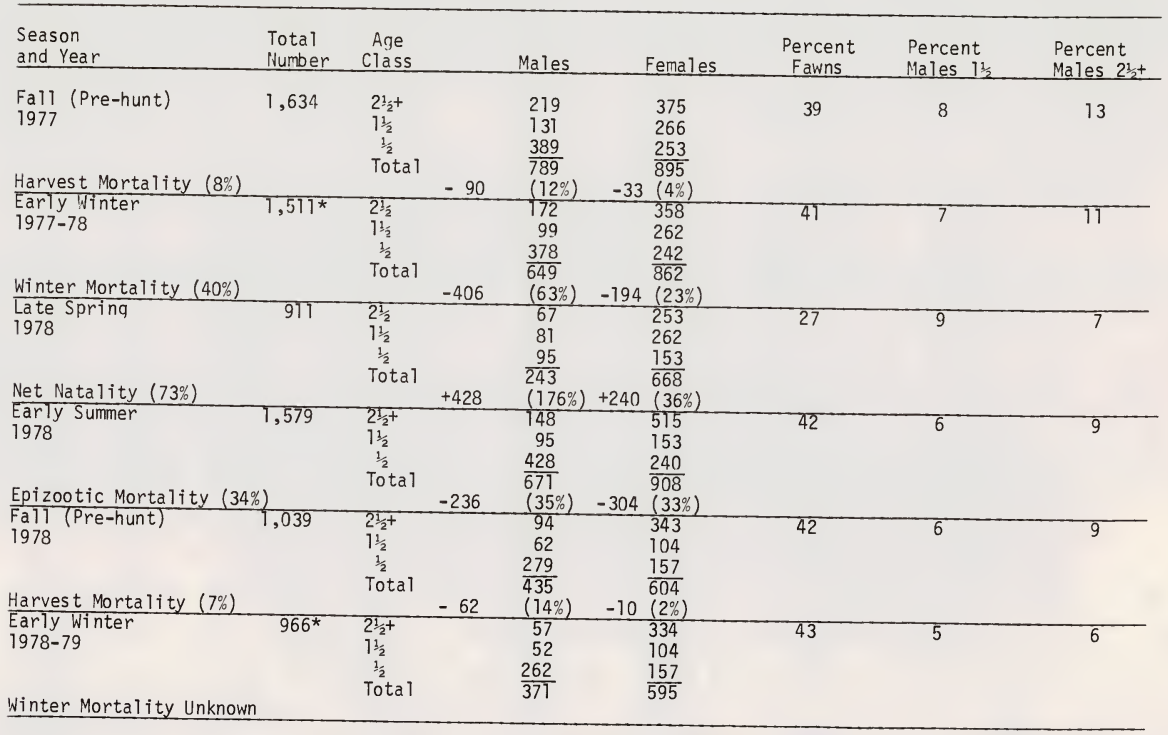


Table 14. Continued.

\begin{tabular}{lllll}
\hline Annual Mortality (Turnover) & Fall'77-Fall'78 & $\frac{\text { Males }}{41 \%}$ & $\frac{\text { Females }}{32 \%}$ & $\frac{\text { Total }}{36 \%}$ \\
\hline & Winter '77-Winter'78-79 & $43 \%$ & $31 \%$ & $36 \%$ \\
\hline
\end{tabular}

* Total early winter population numbers were estimated us ing a formula of Caughley (1977)

$$
N_{x}=\frac{N_{y} n_{x}}{n_{y}}
$$

Where: $N_{x}$ is the population of white-tailed deer; $N_{y}$ is the mule deer population as estimated from aerial census; and $n_{x} / n_{y}$ is the ratio of white-tailed to mule deer determined from vehicle route surveys. Population estimates for other seasons were based on estimated mortality between sex and age classes and
natality from the winter population estimates.

fall 1978 as estimatizootic was determined by subtracting the difference in populations of summer and fall 1978 as estimated from winter populations of 1977-78 and 1978-79, respectively. 
Table 15. Composition by sex and age of 123 white-tailed deer trapped in the Long Pines during the winters of 1976-77, 1977-78 and $1978-79$.

\begin{tabular}{|c|c|c|c|c|c|c|c|c|}
\hline \multirow[b]{2}{*}{ Age Class } & \multicolumn{2}{|c|}{$\begin{array}{c}1976-77 \\
(32)^{a}\end{array}$} & \multicolumn{2}{|c|}{$\begin{array}{c}1977-78 \\
(61)\end{array}$} & \multicolumn{2}{|c|}{$\begin{array}{c}1978-79 \\
(30)\end{array}$} & \multicolumn{2}{|c|}{$\begin{array}{l}\text { Average } \\
\text { (123) }\end{array}$} \\
\hline & Male & Female & Male & Female & & Female & Male & Female \\
\hline $\begin{array}{c}\frac{1}{2} \\
1 \frac{1}{2}+\end{array}$ & $28 b$ & $\begin{array}{l}31 \\
22\end{array}$ & 31 & 20 & 10 & 57 & 23 & 36 \\
\hline & & & & & & & & \\
\hline All age classes & 47 & 53 & 46 & 54 & 27 & 74 & 40 & 60 \\
\hline
\end{tabular}

a Sample size

b Percent of sample

Table 16. Composition by sex and age of white-tailed deer taken by hunters in the Long Pines from 1976-79 from animals checked in the field and from questionnaires.

\begin{tabular}{|c|c|c|c|c|c|c|c|c|c|c|}
\hline Age Class & \multicolumn{2}{|c|}{$\begin{array}{c}1976 \\
(29)^{\mathrm{a}} \\
\text { Male Female }\end{array}$} & \multicolumn{2}{|c|}{$\begin{array}{c}1977 \\
(31) \\
\text { Male Fema le }\end{array}$} & \multicolumn{2}{|c|}{$\begin{array}{c}1978 \\
(22) \\
\text { Male Fema le } \\
\end{array}$} & \multicolumn{2}{|c|}{$\begin{array}{c}1979 \\
(36) \\
\text { Male Female }\end{array}$} & \multicolumn{2}{|c|}{$\begin{array}{c}\text { Average } \\
(118) \\
\text { Male Female } \\
\end{array}$} \\
\hline $\begin{array}{l}\frac{1}{\frac{1}{2}} \\
1^{\frac{1}{2}} \\
2_{2}^{\frac{1}{2}+}\end{array}$ & $\begin{array}{l}3^{b} \\
24 \\
41\end{array}$ & $\begin{array}{r}7 \\
3 \\
21\end{array}$ & $\begin{array}{l}10 \\
26 \\
39\end{array}$ & $\begin{array}{r}10 \\
3 \\
13\end{array}$ & $\begin{array}{l}23 \\
14 \\
50\end{array}$ & $\overline{-}$ & $\begin{array}{r}6 \\
8 \\
33\end{array}$ & $\begin{array}{r}25 \\
28\end{array}$ & $\begin{array}{l}10 \\
18 \\
41\end{array}$ & $\begin{array}{r}10 \\
2 \\
19\end{array}$ \\
\hline
\end{tabular}

All Age Classes:

$\begin{array}{lllllllllll}\text { Field } & 68 & 31 & 75 & 26 & 87 & 14 & 47 & 53 & 69 & 31 \\ \text { Questionnaires } & 66 & 34 & 64 & 36 & 80 & 20 & 57 & 43 & 67 & 33\end{array}$

a Sample size

b Percent of observations 
Table 17. Composition by sex and age of 34 white-tailed deer that died during late winter and early spring 1978 and composition by age among 51 that died during that period among all years.

\begin{tabular}{lllll}
\hline & \multicolumn{5}{c}{$1978(34)^{\mathrm{a}}$} \\
Sex & $1 / 2$ & $1 \frac{1}{2}$ & AGE & \\
\hline M & $47^{\mathrm{b}}$ & 2 & 18 & Unclassified \\
$\mathrm{F}$ & 15 & - & 18 & - \\
\hline
\end{tabular}

A11 Years (51)

All Age

Classes

59

4

33

4

a Sample size

b Percent of sample

was assumed that all parties hunting on national forest were not contacted, although effort was made to do so through all periods of heavy hunter use. The proportion contacted was not determined so a constant of 75 percent was used to calculate harvest during all years. Hunters were not asked to estimate the age of deer they killed when answering the questionnaire but to indicate species and sex (Table 16). Winter populations were adjusted with the harvest figures to obtain fali numbers.

Observed age ratios from fall and winter (Table 12) were not sufficient to estimate winter mortality since adults accounted for 38 percent of this mortality during 1977-78 (Table 17). To determine what proportion of the fawns of early winter died during late winter and early spring 1978, hypothetical ratios of yearling males:females, $1 \frac{1}{2}$ years and older, that would have occurred the following fall under various levels of fawn mortality during winter 1977-78, were compared with that actually observed during fall 1978 (Dusek 1979). An assumed 60 percent of the fawns of early winter 1977-78 had succumbed. Fawn mortality was slanted heavily towards

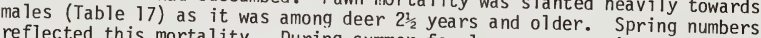
reflected this mortality. During summer females were recruited into the adult population as yearl ings in greater numbers than males $(62: 100)$, whereas ma les outrumbered female fawns the previous winter (158:100) The preponderance of male fawns was also indicated in a fetal sample from late winter and spring 1977 (Table 11). During summer net natality included newborn fawns added to the population based on the fawn:doe ratio observed
during late fall 1978 (Table 12). 
The mortality resulting from EHD during late summer and early fall 1978 was not quantified as such. Effects of an epizootic of hemorrhagic disease along the Yellowstone River during 1977 was not sex specific and not age specific among males (Swenson 1979a). In North Dakota, Hoff et al. (1973) concluded the disease was not sex or age specific. Mortality resulting from the epizootic in the Long Pines in 1978 was determined by subtracting total numbers of summer 1978 from that of fall 1978. Fall numbers of 1978 were calculated from the early winter population estimate of 1978-79 by Caughley's (1977) formula following an early winter census of mule deer. Thirty-four percent of the population of summer 1978 was estimated to have succumbed to hemorrhagic disease (HD). Swenson (1979a) reported a loss of nearly one-third of summer numbers along the Yellowstone River in 1977. Since HD was not assumed to be sex specific, ratios observed in the Model (Table 14) were used to calculate ratios in the fall population of 1978 .

Hunting accounted for an estimated 8 and 7 percent of total fall numbers during 1977 and 1978, respectively (Table 14). Such mortality appeared selective of antlered males and yearling males in particular (Table 16). Antlered whitetails accounted for 65 and 64 percent of the whitetail harvest in 1977 and 1978, respectively, but only 41 percent in 1979. Numbers of antlered males on the study area during fall 1978 constituted only 45 percent of the number occurring during the same period of 1977, while their proportion in the harvest remained relatively stable. Yearling males accounted for 26 and 14 percent of the harvest during 1977 and 1978, respectively, while older males accounted for 39 and 50 percent of the respective harvests (Table 16). Two-year-old males accounted for 26 percent of the 1978 harvest which was the same proportion that year class accounted for as yearlings in 1977. This, combined with two years of low recruitment of yearlings into the adult segment (1978 and 1979 following harsh winters), would have contributed to the lower harvest of antlered males in 1979, which would have consisted primarily of males $3 \frac{1}{2}$ and older. Yearling males accounted for only 8 percent of the

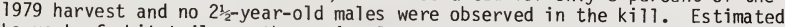
harvest of whitetails on the national forest during 1976-79 was 90, 123, 73 and 83 , respectively. Trends in harvest of males, regardless of age class, from 1976-79 averaged 69 percent among deer checked in the field and 67 percent among parties responding to the questionnaire.

Mortality during late winter and early spring $1978 \mathrm{claimed}$ an estimated 40 percent of early winter numbers or 37 percent of fall numbers. This was slanted towards males, particularly among fawns and adults $2^{\frac{1}{2}}$ and older. This level of mortality occurred during a comparatively harsh winter (Table 1) when deer depended heavily on pine needles for forage due to snow precluding use of most low-growing shrubs. At least 86 percent of animals found dead on the study area during spring 1978 were suffering from malnutrition at the time of death as determined from a subjective examination of femur marrow. Mortality was not estimated for winter 1978-79 since the number of dead deer examined was very small (4) and inconclusive. The fawn:adult ratio and the proportion of fawns observed in the population during spring 1979 were the same as observed during spring 1978 (Table 12) indicating a similar level of mortality may have occurred. The proportion 
of the 1979 harvest consisting of yearling males (8 percent) supported that conclusion. Mortality resulting from hemorrhagic disease during 1978 reduced total numbers of summer by 34 percent (Table 14). No evidence of an epizootic was observed during 1979. Malnutrition during winter, hemorrhagic disease and hunting, in that order of severity (Table i4), reduced population numbers of white-tailed deer on the study area by 36 percent from early winter 1977-78 to the same period of 1978-79. Numbers of males, regardless of age class, were reduced by 43 percent during that period, whereas females were reduced by 31 percent. The net effect of predation, road-kill and poaching was believed to be minor. of 20 marked deer known to have died during the study, which included radioed deer, 12 ( 60 percent) died during winter or early spring and those examined appeared to have suffered from malnutrition. Two having died from collisions with motorized vehicles were the only road-kills observed on the study area. Three of 6 radioed deer died during the epizootic of 1978 . Only one instance of a marked animal having been killed by hunters was reported.

Since winter distribution of whitetails was confined to roughly 28 percent of the study area, early winter densities in that portion averaged 28 and 18 deer $/ \mathrm{mi}^{2}$ ( 11 and 7 deer/ $\mathrm{km}^{2}$ ) during 1977-78 and 1978-79, respectively. The effect density had on levels of mortality resulting from malnutrition and hemorrhagic disease was not determined. Holsworth (1973) reported a direct relationship between deer density and levels of harvest and hunter success. Hunter success, estimated from responses to questionnaires which also included mule deer was 77 and 47 percent during 1977 and 1978, respectively. Harvest followed a similar trend (123 and 73). The slightly higher level of harvest in 1979 (83) compared to 1978 may have reflected the issuance of "B-Tags," which enabled some hunters to harvest an additional whitetail, rather than due to increased numbers of deer on the study area. A comparatively larger proportion of the 1979 harvest consisted of antlerless deer than during other years (Table 16).

It appeared that annual production of fawns during al1 years of study was adequate to maintain relatively stable numbers between years, in light of loss of 40 percent of early winter numbers during severe winters, at present levels of harvest. It also appeared that the producing segment of the population (yearling and older females in winter) were affected less than other sex and age classes (Table 14). However, when harsh winters are followed by an epizootic during late summer, substantial decines in population numbers can be expected. Die-offs during winter should affect levels of harvest and hunter success the following fall only as they affect deer density, which would also occur following an epizootic of hemorrhagic disease. Being sex and/or age specific, winter die-offs of the magnitude observed during this study also can influence the composition of the harvest to older males or a greater proportion of antlerless deer by affecting recruitment of yearlings into the adult segment of the population. It would be expected that mild to average winters would be followed by comparatively higher levels of harvest and hunter success and yearling males accounting for 25 percent or more of annual harvests. 
Mule Deer

Mule deer occurred on the study area at population levels varying from 30 to 50 percent of those of white-tailed deer. Eustace and Swenson (1977) pointed to a decline in mule deer numbers throughout southeastern Montana due to low production and/or low recruitment. Overexploitation due to heavy hunting pressure from 1971-75 may have served to further reduce population numbers. However, these circumstances occurred later and less dramatically in the extreme southeast which included the Long Pines study area. Total numbers and density of mule deer on the study area may have been comparatively low at the onset of this study in September 1976.

Range use and productivity of mule deer in southeastern Montana have been reported by Eustace (1971), Martin (1977), Knapp (1977) and Swenson (1978a). Similar data were gathered on mule deer in the Long Pines study area.

Range Use

\section{Distribution}

Mule deer inhabited approximately 64 percent of the study area (Figure 18). Seasonal changes reflected preferences for topography and vegetational communities as determined from at least 95 percent of 3,719 observations of mule deer during the study. Portions of the study area, where mule deer were observed during only one season and accounted for less than 0.5 percent of total observations, were not included in seasonal ranges. Mule deer inhabited all portions of the study area except the west edge north of Speelman Creek, the extreme southeast corner and the heavily timbered uplands in the central and southeastern portions on the national forest (Fiqure 18).

Approximately 58 percent of annual observations occurred on the national forest with the greatest proportion (65 percent) occurring there during winter and the smallest ( 47 percent) during fall. Seasonal differences may have been partially influenced by light and ground conditions as they affected observability of deer from aerial surveys. For example, snow cover and light conditions during periods of the day when flights were made in winter lent themselves to observing deer in conifer habitat better than during early morning and evening periods in seasons that were snowfree. Two-thirds or more of the observations obtained during fall and winter were from aerial surveys.

During winter 7 areas containing comparatively high numbers of mule deer were identified (Figure 18). Their combined area accounted for roughly 19 percent of the study area or 29 percent of that portion inhabited by mule deer. Sixty-six percent of winter observations, for all winters combined, occurred in those areas which included the northeast corner east of Snow Creek, the Middle and South Forks of Slick Creek, North Tie Creek, lower Maverick Gulch and Speelman Creek, Belltower Rock and the lower portion of Devil's Canyon. 


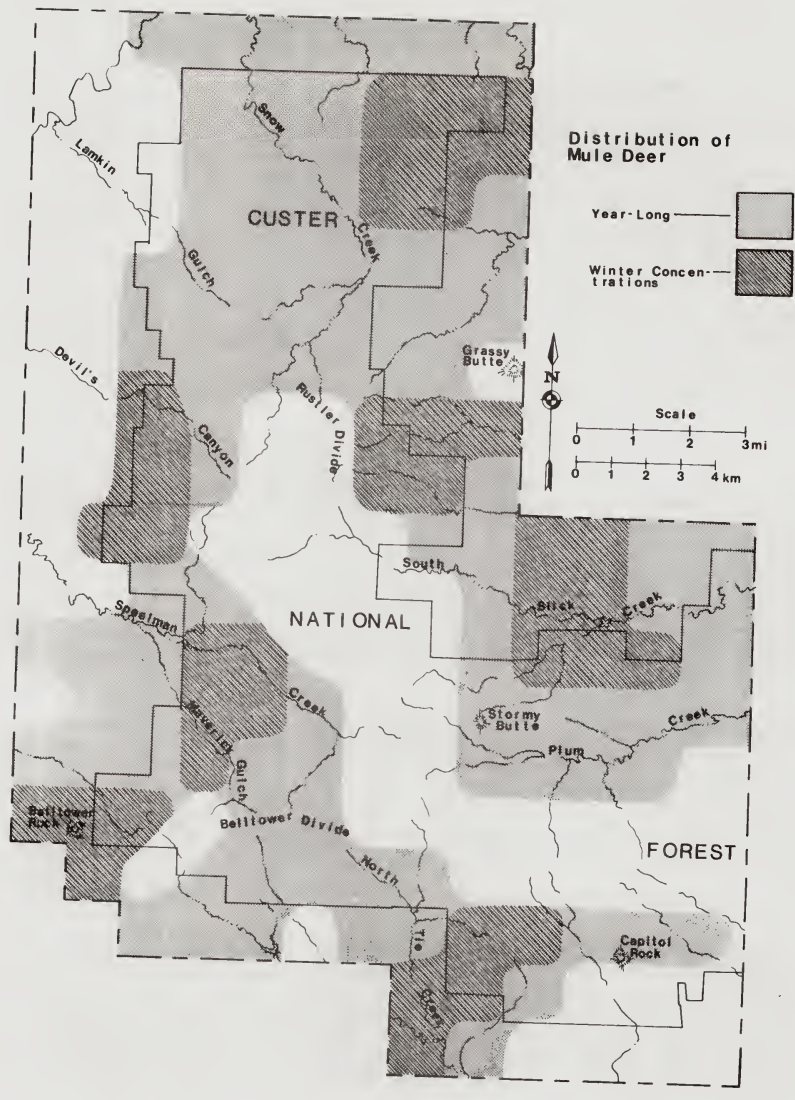

Figure 18. Distribution of mule deer in the Long Pines study area. 


\section{Site Selection}

Ponderosa pine, riparian and badland breaks habitat received use by mule deer, on an annual basis, in greater proportion than their areal representation on the study area, but these preferences were not significant $(P=0.05)$. Xeric and mesic ponderosa pine sites were not differentiated in the statistical analys is. An avoidance of combined grasslands and sagebrush-grasslands was significant $(P<0.05)$ only during fall and winter. Grassland and sagebrush-grassland habitat still accounted for 45 percent of yearlong habitat usage, but covered approximately 61 percent of the study area. Annual use of agricultural areas by mule deer occurred in the

Table 18. Seasonal and annual use of habitat groups by mule deer in the Long Pines study area as determined from both ground and aerial surveys.

Habitat
Group
Ponderosa Pine-
Xeric Grassland

Shrub

$$
20^{b}
$$

45

26

21

28

Ponderosa Pine-

Mesic Shrub

2

3

1

8

3

Riparian Tree/

Shrub

Grass land Park

7

8

19

19

13

Prairie Grass-

1 and

32

23

34

21

Sagebrush-Grass-

land

Badland Breaks

Agricultural
1

6

7
11

6

2
3

3

6
6

4

7
28

12

5

4

5

\footnotetext{
a Sample size.

b Percent of observations
} 
same proportion as the areal representation of this cover type in the study area. Nearly all observations of mule deer in timbered habitat occurred on ponderosa pine-xeric grassland/shrub sites (Table 18) as opposed to heavy use of ponderosa pine-mesic shrub sites by white-tailed deer (Table 3 ). As with whitetails, all observations of mule deer were obtained during daylight periods, and with the exception of winter, primarily during eariy
morning and evening.

Fall - The combined use of ponderosa pine-xeric grassland/shrub, riparian tree/shrub and prairie grassland habitat groups accounted for 79 percent of fall observations (Table 18). A preference for riparian tree/ shrub sites was significant during fall $(P<0.05)$. Swenson (1978a) reported a preference for hardwood draws by mule deer during fall in prairie habitat adjacent to the Yellowstone River. Severson and Carter (1978) observed South Dakota. use of topography, much of $15^{\circ}$ or less accounted for 69 percent of seasonal and 20).

Winter - Mule deer increased their use of ponderosa pine-xeric grassland/ shrub sites from fall to winter (Table 18), while that on riparian tree/shrub and prairie grassland sites declined. A preference for pine habitat during winter was significant $(P<0.05)$. Colder air temperatures during winter 1978-79 (Table 1) may have influenced greater use of pine habitat during that winter as compared to winter 1977-78. During early winter census flights occurred on ponderosa pine 44 and 58 percent of the respective observations a preference for pine habitat by mule and/shrub sites. Knapp (1977) reported Montana and Martin (1977) also reported during winter in southeastern type during winter along Sarpy Creek comparatively heavy use of this Bul1 Mountains (Dusek 1978). As determin similar trend was observed in the habitat usage varied among the three appeared to reflect differences in subunits of the study area and (Table 21). Use of prairie plant communities 3 which included the northern asslands was observed only in subunits 1 and observations of mule deer in and southeastern portions of the study area. in those subunits appeared both grassland parks and prairie grasslands juniper along the east side of ly associated with distribution of horizontal Nearly all use of sagebrush-grasslo study area north of Plum Creek (Figure 18). winter flights occurred in the study area. Those habitat groups were included the southwest portion of and the lower portion of Devil'sroups were abundant along Speelman Creek for 59 percent of all winter 's Canyon. Slopes steeper than 150 accounted (Table 19). Use of south and (Table 20).

Spring - Mule deer decreased their use of ponderosa pine-xeric grassland/shrub sites from winter to spring while increasing their use of and badland breaks also proportion of observations on sagebrush-grasslands values, calculated from spring from winter. Comparatively low chi-square not selecting or avoiding any observations, suggested that mule deer were

They increased 
Table 19. Seasonal and annual distribution of mule deer among four classes of gradient as determined from aerial and ground surveys.

\begin{tabular}{lccccc}
\hline Gradient & $\begin{array}{c}\text { Fal1 } \\
971 \mathrm{a}\end{array}$ & $\begin{array}{c}\text { Winter } \\
1,633\end{array}$ & $\begin{array}{c}\text { Spring } \\
777\end{array}$ & $\begin{array}{c}\text { Summer } \\
328\end{array}$ & $\begin{array}{c}\text { Annual } \\
3,709\end{array}$ \\
\hline $0-15^{0}$ & $69^{\mathrm{b}}$ & 41 & 66 & 61 & 59 \\
$16-30^{\circ}$ & 15 & 23 & 16 & 14 & 17 \\
$31-45^{0}$ & 12 & 24 & 12 & 16 & 16 \\
$46^{0}+$ & 4 & 12 & 6 & 9 & 8 \\
\hline
\end{tabular}

a Sample size

b Percent of observations

Table 20. Seasonal and annual distribution of mule deer among level ridgetops, drainage bottoms and four exposures as determined from aerial and ground observations.

\begin{tabular}{lccccc}
\hline Exposure & $\begin{array}{c}\text { Fal1 } \\
971^{\mathrm{a}}\end{array}$ & $\begin{array}{c}\text { Winter } \\
1,633\end{array}$ & $\begin{array}{c}\text { Spring } \\
777\end{array}$ & $\begin{array}{c}\text { Summer } \\
328\end{array}$ & $\begin{array}{c}\text { Annua } 1 \\
3,709\end{array}$ \\
\hline Leve1 Ridgetop & $10^{\mathrm{b}}$ & 14 & 10 & 6 & 10 \\
Level Bottoms & 40 & 12 & 23 & 32 & 27 \\
North & 14 & 22 & 16 & 13 & 16 \\
East & 14 & 7 & 16 & 18 & 14 \\
South & 14 & 27 & 24 & 15 & 20 \\
Hest & 8 & 19 & 11 & 16 & 13 \\
\hline
\end{tabular}

a Sample size

b Percent of observations 
Table 21. Habitat use by mule deer among three subunits of the Long Pines study area during early winter 1977-78 and 1978-79 combined as determined from intensive aerial surveys.

\begin{tabular}{lcccc}
\hline $\begin{array}{l}\text { Habitat } \\
\text { Group }\end{array}$ & $\begin{array}{c}\text { Subunit } \\
1\end{array}$ & $\begin{array}{c}\text { Subunit } \\
2\end{array}$ & $\begin{array}{c}\text { Subunit } \\
3\end{array}$ & $\begin{array}{c}\text { Tota } \\
862\end{array}$ \\
\hline $\begin{array}{l}\text { Ponderosa Pine-Xeric } \\
\text { Grassland/Shrub }\end{array}$ & $59 b$ & 53 & 40 & 51 \\
$\begin{array}{l}\text { Ponderosa Pine-Mesic } \\
\text { Shrub }\end{array}$ & - & - & - & - \\
$\begin{array}{l}\text { Riparian Tree/ } \\
\text { Shrub }\end{array}$ & trc & 5 & 268 & 2 \\
Grassland Park & 5 & 11 & 7 & 7 \\
Prairie Grassland & 35 & - & 45 & 27 \\
Sagebrush-Grassland & tr & 15 & - & 5 \\
Badland Breaks & 1 & 12 & 3 & 5 \\
Agricultural & - & 5 & 4 & 3 \\
\hline
\end{tabular}

a Sample size

b Percent of sample

c Trace (a value less than 0.5 percent).

their use of drainage bottoms during spring (Table 20) perhaps in response to greenup of herbaceous forage during early April in such areas, although south exposures continued to receive heavy use into spring.

Summer - Although ponderosa pine-xeric grassland/shrub sites and grasslands, which included parks, accounted for nearly half of seasonal observations, use of these habitat groups declined from spring. Use of riparian tree/shrub sites increased (Table 18). Martin (1977) reported comparatively heavy use of riparian habitat by mule deer during summer. Use of riparian tree/shrub sites increased from 15 to 23 percent from early to late summer. Heaviest late summer use of these sites occurred during 1977, the driest year. During late summer of 1977, 1978 and 1979, 36,14 and 23 percent of the observations, respectively, occurred on riparian tree/shrub sites. Seasonal preferences, for all years combined, were not significant $(P=0.05)$. Drainage bottoms continued to receive comparatively
heavy use into summer. 
Food Habits

Food habit data for mule deer were gathered from June 1978 through May 1979, except for late fall samples taken primarily from hunter-killed deer from 1976-79. All but one early winter sample were taken on the national forest. Major forage items used by mule deer in the Long Pines also received substantial use by mule deer in Garfield and Rosebud Counties (Eustace 1971).

Browse, forbs and grasses averaged 68, 24 and 7 percent of the yearlong diet, respectively, determined from analys is of 37 rumens (Table 22). Other than snowberry, major browse species received heavy use only on a seasonal basis.

Fall - Browse accounted for its greatest yearlong use during fall constituting 88 percent of the seasonal diet (Figure 19). Snowberry was the sinqle most abundant item in the fall diet when it also received its greatest use (Table 22). During early fall skunkbush sumac, chokecherry and wild rose also received substantial use. Winter browse, such as rabbitbrush and silver sagebrush, replaced the latter 3 species during late fall. Fall appeared to be a period of transition from summer to winter browse. Oregon grape also received appreciable use by mule deer during late fall. Wild licorice and vellow sweetclover (Melilotus officinalis) were the only forbs identified in more than one fall sample. Grasses accounted for 3 percent of the diet during fall (Figure 19) of which regrowth of bluegrasses accounted for an appreciable proportion (Table 22).

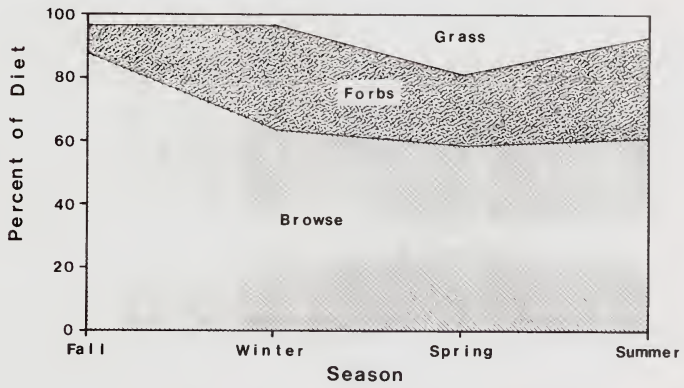

Mule Deer

Figure 19. Seasonal use of forage classes by mule deer in the Long Pines study area. 
Table 22. Semi-seasonal food habits of mule deer in the Long Pines as determined from analysis of 37 rumen samples from 1976-79.a

\begin{tabular}{|c|c|c|c|c|c|c|c|c|}
\hline $\operatorname{Taxa}^{b}$ & $\begin{array}{l}\text { Early } \\
\text { Fall } \\
(3)^{c}\end{array}$ & $\begin{array}{l}\text { Late } \\
\text { Fa } 11 \\
(16)\end{array}$ & $\begin{array}{l}\text { Early } \\
\text { Winter } \\
\text { (4) }\end{array}$ & $\begin{array}{l}\text { Late } \\
\text { Winter } \\
\text { (2) }\end{array}$ & $\begin{array}{l}\text { Early } \\
\text { Spring } \\
\text { (3) }\end{array}$ & $\begin{array}{l}\text { Late } \\
\text { Spring } \\
\text { (3) }\end{array}$ & $\begin{array}{l}\text { Early } \\
\text { Summer } \\
(3)\end{array}$ & $\begin{array}{l}\text { Late } \\
\text { Summer } \\
\text { (3) }\end{array}$ \\
\hline
\end{tabular}

BROUSE :

\begin{tabular}{lcc} 
Artemisia cana & - & $37 / 5^{\mathrm{d}}$ \\
Artemisia tridentata & - & $6 / 1$ \\
Berberis repens & - & $56 / 8$ \\
Chrysothamnus spp. & - & $25 / 11$ \\
Crataegus succulenta & $33 / \mathrm{tr}$ & $12 / 1$ \\
Juniperus communis & - & - \\
Juniperus horizontalis & - & $19 / 1$ \\
Juniperus scopulorum & - & - \\
Pinus ponderosa & - & $12 / \mathrm{tr}$ \\
Populus deltoides & - & $12 / 5$ \\
Prunus virginiana & $100 / 6$ & $6 / 1$ \\
Rhus trilobata & $100 / 15$ & $31 / 1$ \\
Rosa spp. & $100 / 3$ & $50 / \mathrm{tr}$ \\
Shepherdia argentea & - & $12 / \mathrm{tr}$ \\
Symphoricarpos spp. & $100 / 67$ & $87 / 50$ \\
Unidentified Browse & - & $25 / 1$ \\
\hline Total Browse & $100 / 91$ & $100 / 85$
\end{tabular}

\begin{tabular}{l}
$25 / \operatorname{tr}$ \\
- \\
- \\
- \\
- \\
$25 / \operatorname{tr}$ \\
$25 / 1$ \\
- \\
$17 / 45$ \\
- \\
- \\
$75 / 9$ \\
- \\
$25 / 1$ \\
- \\
- \\
\hline $100 / 56$
\end{tabular}

\begin{tabular}{c}
$50 / 18$ \\
$50 / 17$ \\
- \\
$50 / 1$ \\
- \\
- \\
- \\
$100 / 4$ \\
$100 / 23$ \\
$50 / 5$ \\
- \\
- \\
- \\
$50 / \operatorname{tr}$ \\
$100 / 3$ \\
$100 / 1$ \\
\hline $100 / 72$
\end{tabular}

\begin{tabular}{l}
$33 / 9$ \\
- \\
- \\
- \\
- \\
$33 / 1$ \\
$67 / 12$ \\
- \\
- \\
- \\
- \\
- \\
$33 / 1$ \\
$33 /$ tr \\
$33 / 5$ \\
- \\
\hline $100 / 28$
\end{tabular}

\begin{tabular}{l}
$33 / 9$ \\
- \\
- \\
- \\
- \\
$33 / 1$ \\
$67 / 12$ \\
- \\
- \\
- \\
- \\
$33 / 1$ \\
$33 / \operatorname{tr}$ \\
$33 / 5$ \\
- \\
\hline
\end{tabular}

\begin{tabular}{cc}
- & - \\
- & - \\
- & - \\
- & - \\
- & - \\
- & - \\
- & - \\
- & - \\
- & - \\
- & - \\
- & - \\
$100 / 24$ & $100 / 41$ \\
$100 / 15$ & $100 / 10$ \\
$67 / 9$ & $33 / 7$ \\
$100 / 7$ & $100 / 9$ \\
$33 /$ tr & - \\
\hline $100 / 55$ & $100 / 67$
\end{tabular}

FORBS:

Anemone patens

Artemisia frigida

Aster spp.

Commandra umbellata

Glycyrrhiza lepidota

Helianthus spp.

Lactuca spp.

$\begin{array}{ccc}- & - & - \\ - & 6 / 1 & 25 / 1 \\ - & 19 / 1 & - \\ - & - & - \\ - & 25 / 1 & - \\ - & 6 / 1 & -\end{array}$

$\begin{array}{lc}- & - \\ - & 67 / \operatorname{tr} \\ 50 / 1 & - \\ - & - \\ - & 33 / t r \\ - & -\end{array}$

$33 / 14$
-
$33 / 1$
-
-
-
-

$\begin{array}{cc}33 / 8 & 67 / 1 \\ - & - \\ - & - \\ 33 / 3 & - \\ - & - \\ - & - \\ 67 / 1 & -\end{array}$


Table 22. Continued.

\begin{tabular}{|c|c|c|c|c|c|c|c|c|}
\hline Taxa & $\begin{array}{l}\text { Early } \\
\text { Fall } \\
(3) \\
\end{array}$ & $\begin{array}{l}\text { Late } \\
\text { Fa } 11 \\
(16)\end{array}$ & $\begin{array}{l}\text { Early } \\
\text { Winter } \\
\text { (4) }\end{array}$ & $\begin{array}{l}\text { Late } \\
\text { Winter } \\
\text { (2) }\end{array}$ & $\begin{array}{l}\text { Early } \\
\text { Spring } \\
(3)\end{array}$ & $\begin{array}{c}\text { Late } \\
\text { Spring } \\
(3)\end{array}$ & $\begin{array}{l}\text { Early } \\
\text { Summer } \\
(3)\end{array}$ & $\begin{array}{c}\text { Late } \\
\text { Summer } \\
(3)\end{array}$ \\
\hline \multicolumn{9}{|l|}{ FORBS: continued. } \\
\hline $\begin{array}{l}\text { Leguminosae } \\
\text { Medicago sativa } \\
\text { Melilotus officinalis } \\
\text { Tragopogon dubius } \\
\text { Yucca glauca } \\
\text { Unidentified Forbs }\end{array}$ & $\begin{array}{c}33 / \operatorname{tr} \\
33 / \operatorname{tr} \\
33 / 1 \\
33 / \operatorname{tr} \\
- \\
100 / 7 \\
\end{array}$ & $\begin{array}{l}6 / \operatorname{tr} \\
\overline{12 / 1} \\
\overline{-} \\
\overline{75 / 6} \\
\end{array}$ & $\begin{array}{c}\overline{2} \\
\overline{-} \\
\overline{7} \\
7 \overline{5} / 18 \\
25 / \mathrm{tr} \\
\end{array}$ & $\begin{array}{c}- \\
- \\
- \\
50 / 18 \\
100 / 7 \\
\end{array}$ & $\begin{array}{l}33 / \operatorname{tr} \\
- \\
- \\
\overline{3} / \\
33 / 3 \\
\end{array}$ & $\begin{array}{rr}- \\
- \\
33 / & 1 \\
67 / & 5 \\
33 / \mathrm{tr} \\
100 / 17 \\
\end{array}$ & $\begin{array}{c}67 / \operatorname{tr} \\
- \\
- \\
33 / 4 \\
33 / t r \\
100 / 20 \\
\end{array}$ & $\begin{array}{cc}100 / & 1 \\
- \\
- \\
100 / & 4 \\
33 / & 4 \\
67 / & 8 \\
\end{array}$ \\
\hline Total Forbs & $100 / 8$ & $87 / 11$ & $100 / 37$ & $100 / 26$ & $100 / 6$ & $100 / 38$ & $100 / 36$ & $100 / 28$ \\
\hline \multicolumn{9}{|l|}{ GRASSES: } \\
\hline $\begin{array}{l}\text { Poa spp. } \\
\text { Unidentified Grasses }\end{array}$ & $67 / 1$ & $\begin{array}{l}31 / 2 \\
56 / 2 \\
\end{array}$ & $25 / 5$ & $\overline{50 / t r}$ & $100 / 2$ & $\begin{array}{l}100 / 21 \\
100 / 12 \\
\end{array}$ & $\begin{array}{r}33 / 5 \\
100 / 3 \\
\end{array}$ & $6 \overline{7 / 3}$ \\
\hline Total Grasses & $67 / 1$ & $75 / 4$ & $25 / 5$ & $50 / \mathrm{tr}$ & $100 / 2$ & $100 / 33$ & $100 / 8$ & $67 / 3$ \\
\hline
\end{tabular}

\footnotetext{
a Al1 samples, except 11 from late fall, were taken from June 1978-May 1979.

b Includes only those taxa that account for at least 0.5 percent by volume of the diet during a semiseasonal period.

c Sample size.

d Frequency (percent occurrence among samples)/percent of the diet.

e $t r$ - trace (a value less than 0.5 percent).
} 
Winter - Mule deer decreased their use of browse from fall to winter (Figure 19) when this forage class accounted for 64 percent of the diet. One early winter sample, taken in the southwest corner of the study area off the national forest, contained 73 percent alfalfa. Yucca (Yucca glauca) occurred in appreciable quantities in 4 of 6 winter samples. During winter most samples were taken along Speelman and Plum Creeks since they were most accessible during that period. Thus, data appearing in Table 22 are likely not representative of forage use by mule deer throughout the study area in terms of relative abundance of browse species. Silver and big sagebrush and ponderosa pine were major browse items in the samples taken in those drainages. Examination of feeding sites along the east edge of the study area north of Plum Creek during the two previous winters (1976-77 and 1977-78) indicated that horizontal juniper was an important browse item in that part of the study area where both species of sagebrush are generally absent. Feeding sites also indicated that both species of sagebrush were used heavily in Speelman Creek and that pine and yucca received heavy use along lower Plum Creek. The volume of grasses in the winter diet did not change from fall, al though those used consisted of previous years growth.

Spring - Early spring food habits were characterized by comparatively heavy use of browse with combined use of pine, snowberry and horizontal juniper averaging 90 percent of three rumens taken during the period (Table 22). Spring greenup brought about a major change in yearlong food habits of mule deer. Use of browse dropped to its lowest yearly level (Table 22) corresponding with increased use of both forbs and grasses. Among forbs, pasque flower and common salsify were used most heavily, while bluegrasses accounted for nearly two-thirds of late spring use of grasses.

Summer - Mule deer increased their use of browse from late spring to early summer 1978 (Table 22), and this forage class accounted for more than half the summer diet (Figure 19). Summer browse included foliage and the current year's leader growth from skunkbush sumac, wild rose, silver buffaloberry and snowberry. Pasque flower and common salsify received use through summer as did unidentified legumes. Use of grasses declined from spring. Yellow sweetclover was not particularly abundant on the study area during 1978 when summer samples were obtained, but was very abundant during 1979 . Mackie (1970) reported heavy use of this legume in the Missouri River Breaks during years when available. It could potentially. influence the relative use of summer browse and forbs between years.

Population Characteristics

\section{Physical Condition}

Whole and dressed weights were recorded for one $2 \frac{1}{2}$-year-old and two $3 \frac{1}{2}$-year-old females during late August and September 1978. Field-dressed weights of this small sample averaged 8 percent less than the same age classes of females as reported by Mackie (1964) from hunter check stations throughout Montana from 1948-63. Assuming that adult females were rapidly accumulating 
body fat during August and September and that the sample was representative of the respective age classes of adult females, dressed weights of those age classes of females in the Long Pines during late October and November would perhaps not depart appreciably from the statewide averages. Fielddressed weights averaged 70 percent of whole weights for the three adult females from the Long Pines. Robinette et al. (1977) reported an average dressing index of 73.4 percent for mule deer in Utah, but that of lactating females was generally less than that for other females.

A kidney fat index was calculated for each of 29 mule deer. Specimens for early fall, winter, spring and summer were collected from June 1978 through May 1979. Al1 but one of the late fall samples were from hunter killed mule deer during both 1978 and 1979. The other late fall sample, a female fawn, was collected just prior to the opening of the 1978 hunting season. A sample was obtained from a fawn that had entangled itself in a fence during early December 1978. As with white-tailed deer (Figure 17), physical condition of mule deer declined sharply from late fall to early winter (Figure 20), continued to decline into early spring, leveled off through spring and began to increase during early summer. The period from which most of these data were gathered was characterized by lush vegetative growth during summer 1978 and a harsh winter of 1978-79.

Adult males appeared in the best condition during fall of all sex and age classes, followed by yearling males and adult females (Table 23). Yearling females and male fawns were not sampled for comparison. Both fall samples from adult females were taken during September, while those from adult and yearling males were taken mostly from late 0ctober through

Table 23. Seasonal kidney fat indices of mule deer by sex and age class as determined from 29 specimens obtained from June 1978 through
November 1979 .

\begin{tabular}{|c|c|c|c|c|}
\hline $\begin{array}{l}\text { Sex and } \\
\text { Age Class }\end{array}$ & $\begin{array}{l}\text { Fal1 } \\
12 \text { a }\end{array}$ & $\begin{array}{c}\text { Winter } \\
6 \\
\end{array}$ & $\begin{array}{c}\text { Spring } \\
6\end{array}$ & $\begin{array}{c}\text { Summer } \\
5\end{array}$ \\
\hline $\begin{array}{l}\text { Adults } 2 \frac{1}{2}+\text { : } \\
\text { Females } \\
\text { Males }\end{array}$ & $\begin{array}{l}78(2)^{b} \\
345(5)\end{array}$ & $55(5)$ & $\begin{array}{l}12(5) \\
-\end{array}$ & $\begin{array}{l}44(3) \\
19(1)\end{array}$ \\
\hline $\begin{array}{c}\text { Yearlings: } \\
\text { Females } \\
\text { Males }\end{array}$ & $18 \overline{1}(4)$ & - & - & $\overline{8}(1)$ \\
\hline $\begin{array}{l}\text { Fawns: } \\
\text { Females } \\
\text { Males }\end{array}$ & $\begin{array}{l}56(1) \\
-\end{array}$ & $\begin{array}{l}7(1) \\
-\end{array}$ & $\begin{array}{c}14(1) \\
-\end{array}$ & - \\
\hline
\end{tabular}

a Seasonal sample size

b Average kidney fat index (number of specimens). 


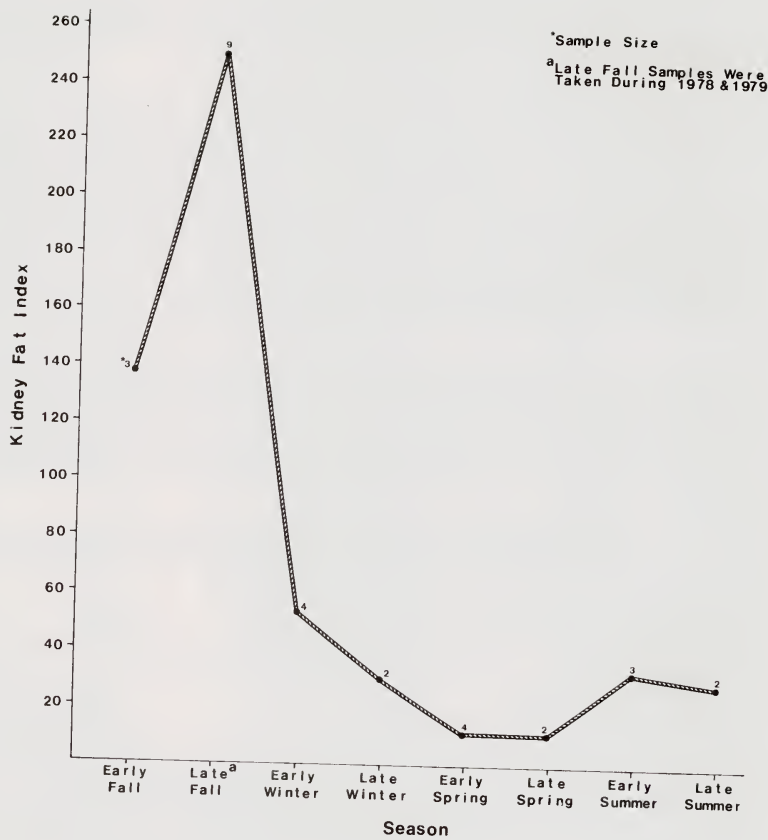

Figure 20. Semi-seasonal trends in physical condition of mule deer in the
Long Pines study area determined from kidney fat indics June 1978-November 1979 .
. 
November. This may have accounted for at least part of the vast differences in indices between the 2 sexes of adults. Fall kidney fat indices varied from 251 to 578 percent among adult males $\left(2 \frac{1}{2}+\right)$ and from 135 to 233 percent among yearling males. Adult females were represented with at least tivo samples during each season (Table 23).

Swenson and Knapp (1979) reported that all condition parameters, which included length of diastema, etc., were consistently lower for yearling males in the hunting districts in the extreme southeast corner of Montana than in two distinct areas to the northwest. The study area lies in that extreme southeast portion. They attributed these differences to nutritional condition among the three areas. Eustace (1971) reported significant differences in protein content, an index of nutritional quality, in forage between Rosebud and Garfield counties. Such regional differences in nutritional quality may influence differences in condition and production.

\section{Prenatal Production}

Reproductive tracts were examined from 11 female mule deer from December 1978 through May 1979. The sample included one fawn, 8 from $2 \frac{1}{2}-7 \frac{1}{2}$ years and 2 that were $8 \frac{1}{2}$ years or older. A11 were pregnant except the fawn and one of the females $8 \frac{1}{2}+$ years, both of which were collected from late March through early April. Corpora lutea of pregnancy were not found in ovaries of either animal.

Of 8 females $2 \frac{1}{2}$ years and older, from which the number of fetuses was determined, 4 each carried single and twin fetuses. No instance of triplet fetuses was observed in the sample. Eustace (1971) reported a much higher rate of twinning in Rosebud and Garfield counties.

An ovulation rate was determined from 7 females $2 \frac{1}{2}$ years and older from which both the number of corpora lutea and fetuses were determined. Thirteen corpora lutea were observed among the 7 females resulting in an ovulation rate of 1.9. Eleven fetuses were present in this sample for a fetal rate of 1.6 per pregnant female. The ovulation rate observed for adult females in the Long Pines approximated that of similar age classes reported for the National Bison Range in western Montana by Nellis (1968), but his observed fetal rate was higher than that observed in the Lonq Pines. The higher rate of ova loss in the Long Pines ( 15 percent) likely resulted from fertilization or implantation faiture or even intrauterine mortality, although no instances of the latter were observed among the sample. In any case the ova loss rate most likely depressed the incidence of twinning in adult females taken from the Long Pines. Eustace (1971) also observed a higher fetal rate than observed in the Long Pines.

Sex was determined for 9 fetuses from 6 females taken from late January through May. The sample of fetuses included 6 males and 3 females.

Breeding dates were estimated for 6 females from ages of fetuses estimated from forehead-rump measurements (Hudson and Browman 1959). Estimated dates of breeding for those females ranged from November 20 to December 27. Assuming a gestation period for mule deer of 203 days 
(Robinette et al. 1977) dates of fawning were estimated to occur from June 11 through July 18, 1979. Since 4 of the 6 would have given birth between June $11-17$, most fawns were presumably dropped about mid-June. Robinette et al. (1977) reported the peak of fawning in Utah to occur from June 19-20. Estimated dates of breeding for 2 females, collected during late April and late May 1979, were December 27 and 15, respectively. It is likely that ages of their respective fetuses were underestimated. Jordan and Vohs (1976) reported that later estimates of ovulation, determined from embryonic development, reflected comparatively poorer condition of does during a severe winter.

\section{Postnatal Production}

The best estimates of annual production of mule deer were obtained during late fall and early winter (Table 24). Postnatal production was higher during 1979 than that of the 3 previous years (Table 24) which corresponded to a comparatively higher rate of twinning and perhaps better reproductive success than occurred during the previous three years (Table 25). The proportion of females $1 \frac{1}{2}$ years and older observed without fawns during fall exceeded 35 percent during all years. Yearling females, which were assumed to be nonproducers (not having bred as fawns), hypothetically accounted for only 18 percent of the adult female segment during summer and fall 1979. This suggested that some older females either did not produce fawn(s) or were not successful rearing them into the fall period. The reproductive performance of mule deer in the study area, in terms of observed fawn:doe and fawn:adult ratios and the percentage of the population consisting of fawns, was lower than that observed among white-tailed deer during all years of study (Tables 12 and 24). Ovulation rates were similar between the species, but fetal rates and the incidence of multiple births were lower among mule deer.

A fawning rate of 1.4 fawns per producing female was calculated for fall 1979. This sample of females undoubtedly included some $2 \frac{1}{2}$-year-olds which would have been yearlings when prenatal data were obtained the previous winter andspring. The observed fetal rate during late winter-spring 1979 was 1.6 fetuses per pregnant female. Yearlings were not among that sample.

The percentage of fawns in the population increased from late fall to early winter by 2 percent during both 1976 and 1977 but by only one percent in 1978 (Table 24). Hunting regulations from 1976-78 in hunting district 781 allowed taking of only antlered mule deer. During 1979 antlerless mule deer were also legal during the final week of the season. As determined from population trends (both pre- and postseason) and harvest trends throughout southeastern Montana from 1959-77 (Eustace and Swenson 1977, Swens on 1978b), such a slight increase in the percentage of fawns from 1 ate fall to early winter perhaps indicated a comparatively low level of harvest on the study area from 1976-79. 
Table 24. Population structure of mule deer in the Long Pines study area from late summer through spring as observed from aerial and ground surveys.

\begin{tabular}{|c|c|c|c|c|c|c|}
\hline Season & $\begin{array}{l}\text { Total } \\
\text { Classi- } \\
\text { fied } \\
\end{array}$ & $\begin{array}{l}\text { Fawns: } \\
100 \\
\text { Does } 1 \frac{1}{2}+\end{array}$ & $\begin{array}{l}\text { Fawns: } \\
100 \text { Adults } \\
1 \frac{1}{2}{ }^{+}\end{array}$ & $\begin{array}{l}\text { Bucks: } \\
100 \\
\text { Does } 1 \frac{1}{2}+\end{array}$ & $\begin{array}{l}\text { Percent } \\
\text { Fawns }\end{array}$ & $\begin{array}{l}\text { Percent } \\
\text { Yr. Bucks }\end{array}$ \\
\hline \multicolumn{7}{|c|}{ Late Summer } \\
\hline 1977 & 55 & 52 & 28 & 87 & 22 & 11 \\
\hline 1978 & 36 & 42 & 29 & 47 & 22 & 8 \\
\hline 1979 & 121 & 73 & 51 & 43 & 34 & 4 \\
\hline \multicolumn{7}{|l|}{ Early Fall } \\
\hline 1977 & 165 & 58 & 46 & 26 & 32 & 8 \\
\hline 1978 & 174 & 47 & 33 & 44 & 25 & 7 \\
\hline 1979 & 47 & 105 & 81 & 37 & 45 & 4 \\
\hline \multicolumn{7}{|l|}{ Late Fall } \\
\hline $1976^{\star}$ & 51 & 58 & 42 & 38 & 29 & 10 \\
\hline 1977 & 66 & 53 & 40 & 31 & 29 & 9 \\
\hline 1978 & 261 & 67 & 50 & 35 & 33 & 5 \\
\hline 1979 & 153 & 81 & 63 & 29 & 39 & 10 \\
\hline \multicolumn{7}{|c|}{ Early Winter } \\
\hline $1976-77$ & 95 & 57 & 44 & 29 & 31 & 11 \\
\hline $1977-78$ & 507 & 52 & 46 & 14 & 31 & 5 \\
\hline $1978-79$ & 398 & 60 & 51 & 17 & 34 & 5 \\
\hline \multicolumn{7}{|l|}{ Late Winter } \\
\hline 1977 & 233 & - & 48 & - & 33 & - \\
\hline 1978 & 183 & - & 38 & - & 27 & - \\
\hline 1979 & 158 & - & 45 & - & 31 & - \\
\hline \multicolumn{7}{|l|}{ Spring } \\
\hline 1977 & 279 & - & 34 & - & 25 & - \\
\hline 1978 & 180 & - & 28 & - & 22 & - \\
\hline 1979 & 263 & - & 37 & - & 27 & - \\
\hline
\end{tabular}

* Late fall samples also included early fall observations.

Table 25. The proportion of single or pairs of female mule deer $1 \frac{1}{2}$ years and older that were accompanied by zero, 1 or 2 fawns during fal1 1977-79.

\begin{tabular}{lcccc}
\hline $\begin{array}{l}\text { Number of } \\
\text { Fawns }\end{array}$ & 1977 & 1978 & 1979 & $\begin{array}{c}\text { Average } \\
(234)\end{array}$ \\
\hline & $(59) \mathrm{a}$ & $(107)$ & $(68)$ & \\
0 & $44^{\mathrm{b}}$ & 56 & 37 & 46 \\
1 & 34 & 32 & 32 & 33 \\
2 & 22 & 12 & 31 & 22 \\
\hline
\end{tabular}

a Sample size

b Percent of sample. 


\section{Population Trends}

Swenson (1978b) hypothesized the level of fawn production necessary to maintain stable mule deer populations in southeastern Montana as affected by varying levels of hunting pressure: a post-season mule deer population subjected to heavy pressure required 40 percent fawns; whereas 30-35 percent fawns were essential to maintainina stable populations in areas experiencing light hunting pressure. He tentatively defined "light" hunting pressure as that experienced from 1976-77 where only antlered mule deer could be taken. Harvest of mule deer in the study area from 1976-79 was estimated only for the national forest from questionnaires in the same manner as for white-tailed deer. Since nearly half of fall observations of mule deer occurred on lands other than national forest, it was assumed that a portion of annual harvests of mule deer in the study area also came from private, state or BLM lands but was not quantified. Based on an assumed differential accessibility of national forest and private lands, national forest lands likely accounted for at least half of annual harvests of mule deer. Levels of harvest on the entire Long Pines unit of the national forest from 1976-79 were $0.1,0.3,0.5$ and 0.2 mule deer per mile2, respectively (tr, $0.1,0.2$ and $0.1 / \mathrm{km}^{2}$ ).

Early winter population estimates of mule deer were determined from census flights during 1977-78 and 1978-79. Total numbers observed during 1977-78 were used as an expression of the early winter population, al though it was assumed an absolute total count was not achieved due to observability biases imposed by canopy of timber. Temperature, wind and snow cover conditions were fairly uniform throughout the period that all three subunits were surveyed during 1977-78. During 1978-79 most favorable censusing conditions occurred only while censusing the northern subunit. During periods of early January, when the southeast and southwest subunits were flown, air temperatures were below zero $F$ and deer were generally less observable due to comparatively heavier use of timbered habitat in 1979. Numbers of deer observed in those subunits during 1978-79 were adjusted to approximate the proportion observed there the previous year.

A model (Table 26), including estimated total numbers, seasonal composition by sex and age class, mortality and natality was derived from early winter estimates of 1977-78 and 1978-79 and sex and age ratios observed in early winter populations (Table 24). Total numbers during fall 1977 and 1978 were estimated by adding hunting mortality to early winter totals. Only 27 mule deer were aged in the field during the hunting seasons of 1976-79, all of which were antlered males. Seventy-four percent were $2 \frac{1}{2}$ years and older for all years combined. The sample did not include 2 illegally-killed antlerless mule deer known to have been taken during 1978. Total numbers for fall were undoubtedly disproportionately underestimated since estimated hunting mortality included only those taken on the national forest.

Mortality among adults during late winter and early spring was assumed to be negligible since only fawns were found dead on the study area during spring 1978. No dead mule deer were examined during spring 1979, but local 
Table 26. A model of population size, composition and turnover of mule deer in the Long Pines from Fall 1977 through summer 1979.

\begin{tabular}{|c|c|c|c|c|c|c|c|}
\hline \multirow{2}{*}{$\begin{array}{l}\text { Season } \\
\text { and Year }\end{array}$} & \multirow{2}{*}{$\begin{array}{l}\text { Total } \\
\text { Number }\end{array}$} & \multirow{2}{*}{$\begin{array}{c}\text { Age } \\
\text { Class }\end{array}$} & \multicolumn{2}{|c|}{ Number } & \multirow{2}{*}{$\begin{array}{l}\text { Percent } \\
\text { Fawns }\end{array}$} & \multirow{2}{*}{$\begin{array}{l}\text { Percent } \\
\text { Males } 1 \frac{1}{2}\end{array}$} & \multirow{2}{*}{$\begin{array}{l}\text { Percent } \\
\text { Males } 2 \frac{1}{2}+\end{array}$} \\
\hline & & & Males & Females & & & \\
\hline $\begin{array}{l}\text { Fa11 (Pre-hunt) } \\
1977 \\
\text { Harvest Mortality (7\%) }\end{array}$ & 490 & $\begin{array}{c}2 \frac{1}{2}+ \\
1 \frac{1}{2} \\
\frac{1}{2} \\
\text { Total }\end{array}$ & $\begin{array}{r}34 \\
39 \\
71 \\
144 \\
-32(22 \%)\end{array}$ & $\begin{array}{r}227 \\
48 \\
\quad 71 \\
346\end{array}$ & 29 & 8 & 7 \\
\hline $\begin{array}{l}\text { Early Winter } \\
1977-78 \\
\text { Winter Mortal ity }(12 \%)\end{array}$ & $458^{*}$ & $\begin{array}{c}2 \frac{1}{2}+ \\
1 \frac{1}{2} \\
\frac{1}{2} \\
\text { Total } 1\end{array}$ & $\begin{array}{c}18 \\
23 \\
71 \\
\frac{112}{-28(25 \%)} \\
\end{array}$ & $\begin{array}{r}227 \\
48 \\
71 \\
\quad 346 \\
-27(8 \%) \\
\end{array}$ & 31 & 5 & 4 \\
\hline $\begin{array}{l}\text { Late Spring } \\
1978 \\
\text { Net Natality }(53 \%) \\
\end{array}$ & 403 & $\begin{array}{c}2 \frac{1}{2}+ \\
1 \frac{1}{2} \\
\frac{1}{2} \\
\text { Total }\end{array}$ & $\begin{array}{r}18 \\
23 \\
43 \\
84 \\
+107(127 \%) \\
\end{array}$ & $\begin{array}{r}227 \\
48 \\
44 \\
319 \\
+107(34 \%) \\
\end{array}$ & 22 & 6 & 4 \\
\hline $\begin{array}{l}\text { Summer } \\
1978\end{array}$ & 617 & $\begin{array}{c}2 \frac{1}{2}+ \\
1 \frac{1}{2} \\
\frac{1}{2} \\
\text { Total }\end{array}$ & $\begin{array}{r}31 \\
43 \\
107 \\
181\end{array}$ & $\begin{array}{r}275 \\
44 \\
107 \\
426\end{array}$ & 35 & 7 & 5 \\
\hline $\begin{array}{l}\text { Fa11 (Pre-hunt) } \\
1978 \\
\text { Harvest Mortality }(9 \%)\end{array}$ & 530 & $\begin{array}{c}2 \frac{1}{2}+ \\
1 \frac{1}{2} \\
\frac{1}{2} \\
\text { Total }\end{array}$ & $\begin{array}{c}61 \\
34 \\
80 \\
175 \\
-47(27 \%) \\
\end{array}$ & $\begin{array}{r}227 \\
48 \\
80 \\
355\end{array}$ & 30 & 6 & 11 \\
\hline $\begin{array}{l}\text { Eary Hinter } \\
1978-79 \\
\text { Winter Mortality }(9 \%)\end{array}$ & $483^{*}$ & $\begin{array}{c}2 \frac{1}{2}+ \\
1 \frac{1}{2}+ \\
\frac{1}{2}+ \\
\text { Total }\end{array}$ & $\begin{array}{c}24 \\
24 \\
80 \\
128 \\
-22(17 \%)\end{array}$ & $\begin{array}{r}227 \\
48 \\
80 \\
\quad 355 \\
-21 \quad(6 \%) \\
\end{array}$ & 33 & 5 & 5 \\
\hline
\end{tabular}


Table 26. Continued

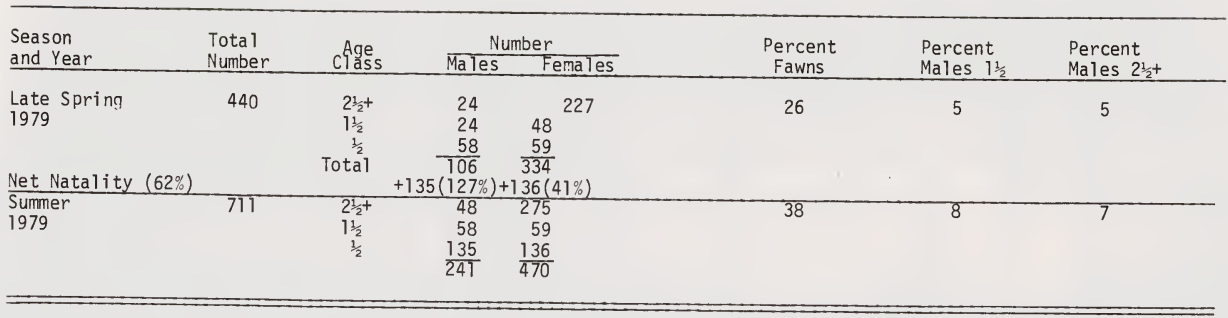

* Early winter population estimates were made from aerial censuses during late December through mid-January 1977-78 and 1978-79. The 1977-78 estimate is unadjusted, while that of 1978-79 was adjusted to compensate for a change in air temperature which was believed to have influenced observability of deer during the period flights were made. Composition of fawns and yearling and older males from early winter was incorporated into the model, while composition during other seasons was derived from changes in the population from mortality or natality. 
residents reported finding dead fawns in or near haystack yards. Early winter numbers were adjusted accordingly calculating the overwinter loss from early winter and spring fawn:adult ratios (Table 24). The number of winter-killed fawns identified to sex (4) was too small to estimate a sex ratio, so spring numbers were estimated without regard to differential mortality of fawns.

Total numbers in summer were estimated by adding net natality, which was determined from late fall fawn: doe ratios of 1978 and 1979 (Table 24). A sex ratio among newborn fawns was not determined for either year. In the model fawns were added to the population in nearly equal numbers of males and females, although this may not actually occur in the population. There was a discrepancy between total numbers in summer and fall 1978, which had been derived from early winter estimates of 1977-78 and 1978-79, respectively. This was perhaps at least partially attributable to disproportionately underestimating harvest mortality during fall 1978 as well as disproportionately underestimating total numbers of early winter 1978-79 as compared to the previous year due to differences in observability of deer. Little or no summer loss of mule deer was believed to have occurred from EHD. Dead mule deer were not found on the study area during that period of 1978. It was also indicated, through presence of neutralizing antibodies for EHD virus among 14 of 18 samples of blood serum from mule deer, that those having been exposed to the virus had probably recovered

In light of two comparatively harsh winters, winter mortality of mule deer, in terms of the proportion of the population that succumbed, appeared negligible when compared with that of white-tailed deer (Tables 14 and 26). During 1977-78 and 1978-79, an estimated 39 and 27 percent of the fawns of early winter had died, respectively. This accounted for a population decline of 12 and 9 percent from winter to spring during the respective years. The population appeared to be increasing, at least slightly, with 31 to 33 percent of early winter populations consisting of fawns. The comparatively higher fawn production of 1979 should be followed by a more substantial increase in 1980. These trends occurred under comparatively light levels of harvest $(\leq 0.5 \mathrm{MD} / \mathrm{mi} .2)$ when considering harvest on the entire Long Pines unit of the national forest. Population density on the entire national forest was 2 or more deer per mile $e^{2}$ during the study. However, mule deer density was 5 and 6 deer per mile 2 ( 1 deer $/ \mathrm{km}^{2}$ ) during 1977-78 and 1978-79 in only the portion of the study area inhabited by mule deer, based on the assumption that they inhabited approximately 44 percent of the study area.

Of 28 individuals $2 \frac{1}{2}$ years and 01 der, whose ages were assigned either by tooth eruption and wear or by cementum analysis of a middle incisor from June 1978 through May 1979, 75 percent, regardless of sex, were assigned ages of $2 \frac{1}{2}$ to $4 \frac{1}{2}$ indicating a relatively young population. Nine of 12 males were assigned ages of $2 \frac{1}{2}$ and $3 \frac{1}{2}$ years. The sample did not include males older than $5 \frac{1}{2}$ years. Among females, $3 \frac{1}{2}-y$ ear-olds (1975 year class) were the most abundant age class accounting for 31 percent of 16 adult females. Females $8 \frac{1}{2}+$ years accounted for 19 percent of the sample. The 1971-72 year classes were the most poorly represented. Numerically it appeared that the 1975 year class was predominant among breeding age females from 
1976-79, producing their first crop of fawns during 1977. Robinette et al. (1977) reported that ovulation and fetal rates increased with age at least up to $8 \frac{1}{2}$ years. If the 1975 year class was prevalent among breeding age female mule deer in the Long Pines study area, it would at least partially explain comparatively lower production observed during 1977 and 1978 as compared to 1979 (Table 24). The significance of the female segment of the 1975 year class being numerically strong is that adult female mule deer were protected after 1975 and this year class was perhaps less sought after as fawns (Eustace and Swenson 1977).

\section{Antelope}

Antelope were generally associated with private, state and BLM Iand adjacent to the national forest. Range use and livestock relations of antelope were studied by Campbell (1970) and Freeman (1971) in a portion of Carter County lying south of the Long Pines west of the Little Missouri River. Numerically antelope were not as abundant on the study area as were white-tailed and mule deer. Aerial surveys were conducted during July 1977-78 and August 1979 to determine summer distribution and habitat use of antelope as well as yearly trends in numbers and composition of the population. Such data were not gathered during other periods of the year Range Use

Distribution of antelope on the study area was determined from observations of 827 individuals during the three summers of study. Only 17 percent of those observations occurred on the national forest, of which most were observed along Snow Creek (Figure 21). During summer 32 percent of the study area was occupied by antelope. This distribution did not change between years with consistently greater numbers observed in subunit 1 as compared to subunits 2 and 3 (Table 27). Four areas of summer concentration were identified on the study area (Figure 21). The largest concentration occurred in the Snow and Slick Creek drainages near Grassy Butte. Others occurred on Tie Creek, north of Belltower Rock and in the northwest corner of the study area between Devil's Canyon and Boxelder Creek.

Seventy-six percent of the antelope occurred on prairie grasslands with the remainder on sagebrush-grasslands and in agricultural areas. Campbel1 (1970) reported comparatively heavy use of grassland and agricultural areas during summer. A preference for combined grasslands and sagebrushgrasslands in the study area was significant $(P<0.05)$, Campbel1 (1970) reported summer home ranges of $2.2,0.9$ and 3.3 miles $^{2}(5.7,2.3$ and $8.5 \mathrm{~km}^{2}$ ) for doe/fawn groups, territorial males and bachelor male groups,
respectively.

Freeman (1971) reported sagebrush-wheatgrass types receiving nearly all winter use by antelope. Antelope that summered on the study area probably wintered to the east near the Little Missouri River in South Dakota and along Boxelder Creek in Montana lying west of the study area. grasslands were abundant. grasslands were abundant. Antelope were observed on the national forest 


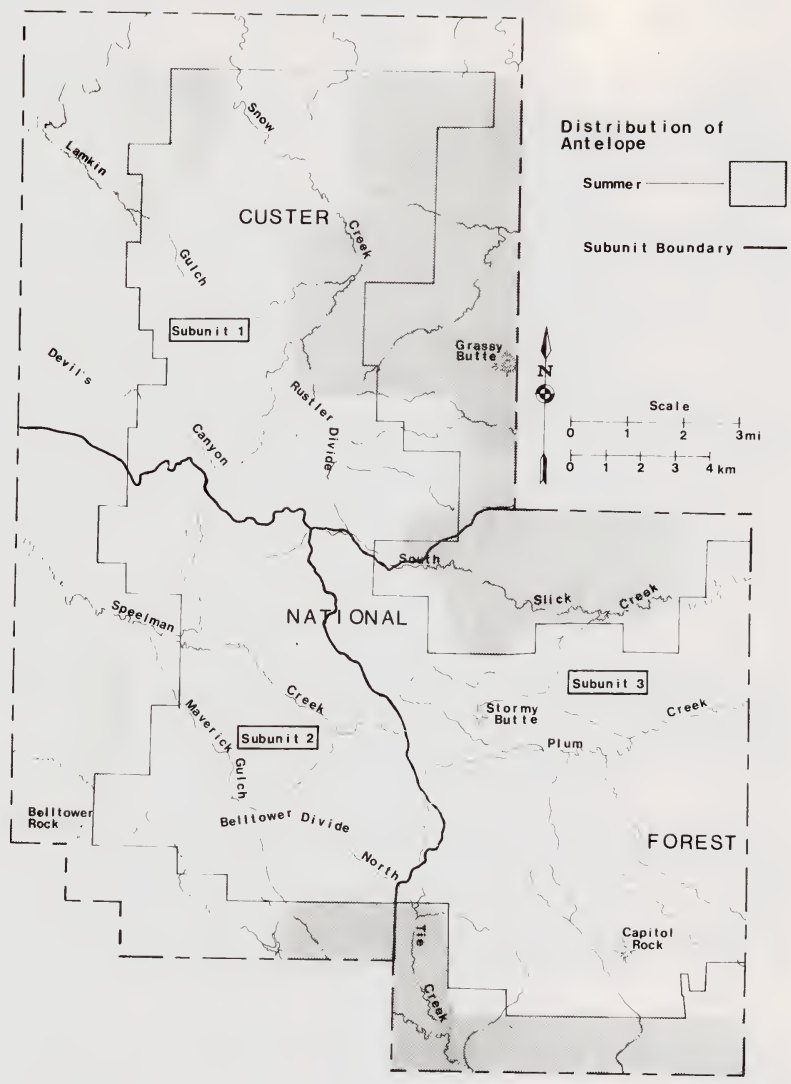

Figure 21. Summer distribution of antelope in the Long Pines study area. 
in upper Plum Creek following a severe winter storm in February 1978. They were using badland breaks habitat. Following the first major winter storm in November 1979, antelope were observed in timbered habitat on the national forest and in grassland parks on the Belltower Divide.

\section{Population Characteristics}

The study area occurred in antelope hunting district 780 . Numbers of antelope observed on the study area declined from 384 in 1977 to 126 in 1979 representing a decline of 67 percent (Table 27). During the same period numbers of antelope declined from 20 to 90 percent in all but one hunting district in the administrative region ( $R-7)$ comprising southeastern Montana (Martin 1980). These declines were attributed to high mortality as a result of severe winter weather in 1977-78 and especially in 1978-79. In the study area the greatest decline in numbers occurred from 1978-79. Numbers declined only 17 percent from 1977-78. Wentland (1979) reported a 22 percent decline from 1977-78 among hunting districts surveyed during July 1978, but hunting district 780 was not surveyed that year. Fawn production declined on the study area from 88 fawns:100 females $\left(1 \frac{1}{2}+\right)$ in 1977 to $46: 100$ in 1979. The number of adult females $\left(1 \frac{1}{2}+\right)$ was reduced 50 percent from 1977-79 while males were reduced 90 percent suggesting that winter mortality was sex specific at least among adults. Summer densities throughout the portion of the study area inhabited by antelope were $6.3,5.2$ and 2.1 per mile2 $(2.4,2.0$ and $0.8 / \mathrm{km} 2)$ during 1977,1978 and 1979 , respectively.

\section{Miscellaneous Sightings of Big Game}

A mountain 1 ion (Felis concolor) was sighted by the author on the national forest during October 1977. Occurrence of this species in Carter County was believed 1 imited to an occasional transient (Lampe et al. 1974). Two additional sightings were reported between November 1977 and August 1978: one by deer hunters; and the other by a U.S. Forest Service employee. Others reported seeing tracks of a lion during March 1977.

Three sightings of elk (Cervus canadensis) were made by the author from October 1978 to May 1979 and all were assumed to be of the same animal. The last reported sighting was by a U.S. Forest Service employee during summer 1979. The animal sighted in each instance was an adult cow. The Long Pines are apparently part of the historical range of elk with the last native elk being killed about 1879 (Murie 1951). They were reported to have disappeared from the valley of the Little Missouri during that same time frame as reported by T. Roosevelt (Koch 1941).

\section{Merriam's Turkey}

Merriam's turkeys were released near Capitol Rock in the Long Pines in January 1955 in an attempt to establish populations of wild turkeys in Montana. The ancestral range of this subspecies is limited to woodland areas of Arizona, Colorado and New Mexico (Ligon 1946). Rose (1956) indicated this introduction was quite successful since the population increased to more than 80 birds in the first year from the 18 that were released. By 1957 the number of birds on the area was estimated to be about 700 . 
Table 27. Population numbers and composition of antelope in the Long Pines study area as determined from aerial surveys during July 1977-78 and August 1979.

\begin{tabular}{|c|c|c|c|c|c|c|c|c|}
\hline Area & Females & $\frac{\text { ts }}{\text { MaTes }}$ & Fawns & Total & $\begin{array}{l}\text { Fawns: } \\
100 \text { Does }\end{array}$ & $\begin{array}{l}\text { Fawns: } \\
100 \text { Adults }\end{array}$ & $\begin{array}{l}\text { Bucks: } \\
100 \text { Does }\end{array}$ & $\begin{array}{l}\text { Percent } \\
\text { Fawns }\end{array}$ \\
\hline $\begin{array}{c}\text { Subunit } 1 \\
1977 \\
1978 \\
1979\end{array}$ & $\begin{array}{l}86 \\
85 \\
38\end{array}$ & $\begin{array}{r}49 \\
47 \\
3\end{array}$ & $\begin{array}{l}73 \\
66 \\
20\end{array}$ & $\begin{array}{r}208 \\
198 \\
61\end{array}$ & $\begin{array}{l}85 \\
78 \\
53\end{array}$ & $\begin{array}{l}54 \\
50 \\
49\end{array}$ & $\begin{array}{r}57 \\
55 \\
8\end{array}$ & $\begin{array}{l}35 \\
33 \\
33\end{array}$ \\
\hline $\begin{array}{c}\text { Subunit } 2 \\
1977 \\
1978 \\
1979\end{array}$ & $\begin{array}{l}19 \\
20 \\
12\end{array}$ & $\begin{array}{r}13 \\
10 \\
1\end{array}$ & $\begin{array}{r}20 \\
21 \\
9\end{array}$ & $\begin{array}{l}52 \\
51 \\
22\end{array}$ & $\begin{array}{r}105 \\
105 \\
75\end{array}$ & $\begin{array}{l}62 \\
70 \\
69\end{array}$ & $\begin{array}{r}68 \\
50 \\
8\end{array}$ & $\begin{array}{l}38 \\
41 \\
41\end{array}$ \\
\hline $\begin{array}{c}\text { Subunit } 3 \\
1977 \\
1978 \\
1979\end{array}$ & $\begin{array}{l}58 \\
33 \\
31\end{array}$ & $\begin{array}{r}16 \\
10 \\
4\end{array}$ & $\begin{array}{r}50 \\
25 \\
8\end{array}$ & $\begin{array}{r}124 \\
68 \\
43\end{array}$ & $\begin{array}{l}86 \\
76 \\
26\end{array}$ & $\begin{array}{l}68 \\
58 \\
23\end{array}$ & $\begin{array}{l}28 \\
30 \\
13\end{array}$ & $\begin{array}{l}40 \\
37 \\
19\end{array}$ \\
\hline
\end{tabular}


Jonas (1966) evaluated the life history, habitat use and production, which provided the foundation for management of turkeys in Montana, resulting from a three-year study in the Long Pines during the early
$1960^{\prime} \mathrm{s}$.

Range Use

\section{Distribution}

With the exception of winter turkeys observed on the study area occurred primarily on the national forest (Figure 22). Too few observations were obtained during this study to identify areas of relative abundance, although spring, summer and fall observations occurred in the upper reaches of the major drainages. During the three winters of study turkeys were repeatedly observed along Tie Creek on privately owned lands (Figure 22). As many as 50 turkeys were observed wintering in that area. Local residents reported seeing turkeys wintering there prior to this study. During winter 1976-77 turkeys were sighted on two occasions in the extreme upper Snow Creek drainage. Turkey sign, which included tracks and scratching in snow and duff, was abundant from upper Snow Creek south to extreme upper South Slick Creek. Tracks were observed in Wickham Gulch during winter 1977-78 indicating that turkeys may also winter in that area.

Both Rose (1956) and Jonas (1966) reported that turkeys wintered at lower elevations in or near the Long Pines from where they had summered. During this study they were only observed along Tie Creek during winter. Turkeys generally wintered along major drainage bottoms and dispersed into adjacent uplands during spring in the Bull Mountains of southcentral Montana (Dusek 1978).

\section{Site Selection}

Seasonal habitat use is based on that reported by Jonas (1966) from observation of over 6,000 turkeys. Grassland parks, or prairie grasslands adjacent to stands of pine, accounted for $36,22,55$ and 35 percent of fall, winter, spring and summer observations, respectively. Snowberry, either along draws, or on forest-grassland ecotone sites, received its greatest use during spring and summer accounting for 25 and 31 percent of the respective seasonal observations. In the Bull Mountains 80 percent of annual observations were within 100 yards $(91.4 \mathrm{~m})$ from the nearest stand of ponderosa pine (Dusek 1978). Ponderosa pine accounted for 30 and 22 percent of summer and fall observations, respectively (Jonas 1966). ( 55 years) collectively commonly by turkeys included medium aged stands nearly all collectively referred to as "pole" stands. During winter, Turkeys observed riparian areas or in areas where during this study were either in the observed habitat usage by turkeys in 


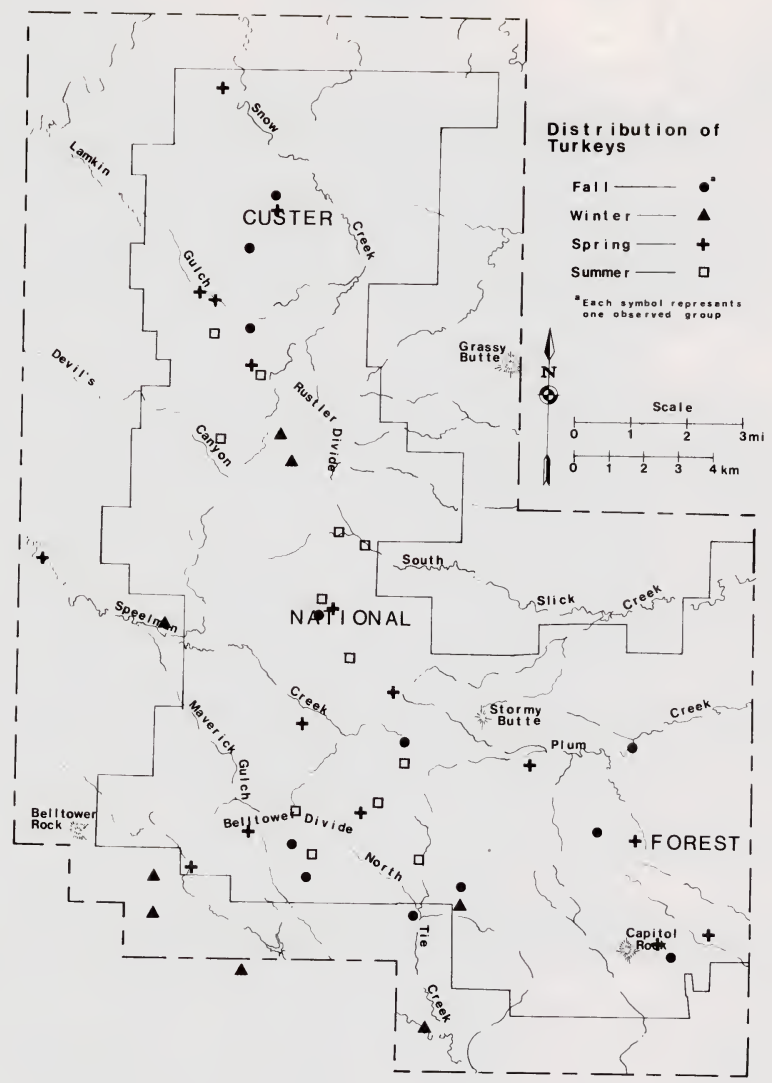

Figure 22. Distribution of turkeys in the Long Pines study area. 
following their release, and his findings closely resembled those of Jonas (1966). Rose (1956) reported comparatively heavy use of dense stands of pine during late summer and heavy use of 1 ivestock feeding areas during winter. Both authors reported roostingsites to consist of mature to over mature pine trees on sparsely timbered slopes. Roost trees observed during this study fell within that category. During winter turkeys were often observed perched on haystacks or in deciduous trees along the draws. The configuration of habitat described by DuBois (1979) for her savanna breeding bird density plot in the extreme upper Snow Creek drainage was perhaps representative of optimal summer habitat for turkeys in the Long Pines since it contained abundant grasslands, stands of pine, snowberry draws and ecotonal, or edge, communities.

\section{Food Habits}

Fall food habits of turkeys were evaluated from analys is of the contents of 17 crops from hunter-killed birds from 1976-79 (Table 28). Plant and animal material accounted for 59 and 39 percent, respectively, of the fall diet during the study. Major plant items included mast from ponderosa pine, seeds from prairie coneflower and fruits from wild rose, skunkbush sumac, snowberry and fleshy hawthorn. Animal material consisted almost entirely of grasshoppers (Orthoptera). The proportion of plant and animal material in the fall diet varied between years and was perhaps influenced by availability of grasshoppers and/or mast from pine. Jonas (1966) correlated heavy use of pine seeds by turkeys with years of good mast production and suggested a preference for this item when available by a scarcity of other items in the diet. During this study, only 1977 appeared to be a year of good mast production when it was present in all samples averaging 60 percent by volume (Table 28). Fall food habits observed during this study approximated those observed by Jonas (1966) in the Long Pines and those observed in the Bull Mountains by Dusek (1978). These data exemplified the importance of the association of grassland parks, ponderosa pine, riparian and ecotone types as foraging areas for turkeys. One crop examined during spring 1979 contained petals from pasque flower and leaves from buttercup (Ranunculus spp.).

Production and Populations

Five and eight brood flocks of turkeys were observed during July and August of 1977 and 1978, respectively. None were observed during 1979 perhaps due to decreased effort in locating them. In the case of Merriam's turkey, individual broods often combine when poults are 7-10 days old, thus forming brood flocks (Jonas 1966). Annual production, in terms of poults:hen was 6.4 and 5.3 in 1977 and 1978, respectively. Jonas (1968) reported annual production of 6.8 poults:hen in the Long Pines from 1961-63 and that adverse weather during the period of incubation adversely affects reproductive success. Precipitation was more than 3.5 inches $(8.9 \mathrm{~cm})$ above normal during May 1978 while temperatures were 
Table 28. Fall foods of Merriam's turkeys in the Long Pines from 1976-79 as determined from analys is of crop contents of 17 hunter-killed birds.

\begin{tabular}{|c|c|c|c|c|}
\hline Taxaa & $\begin{array}{c}1976 \\
5 \mathrm{C} \\
\end{array}$ & $\begin{array}{c}1977 \\
6 \\
\end{array}$ & $\begin{array}{c}1978 \\
5 \\
\end{array}$ & $\begin{array}{l}\text { All } \\
\text { Years } \\
17\end{array}$ \\
\hline \multicolumn{5}{|l|}{ Plant Material: } \\
\hline $\begin{array}{l}\text { Achillea millefolium (Leaves) } \\
\text { Berberis repens (Fruit) } \\
\text { Crataegus succulenta (Fruit) } \\
\text { Pinus ponderosa (Seeds) } \\
\text { Poa spp. (Leaves) } \\
\text { Poa spp. (Seeds) } \\
\text { Prunus virginiana (Fruit) } \\
\text { Ratibida columnifera (Seeds) } \\
\text { Rhus trilobata (Fruit) } \\
\text { Ribes spp. (Fruit) } \\
\text { Rosa spp. (Fruit) } \\
\text { Shepherdia argentea (Fruit) } \\
\text { Symphoricarpos spp. (Fruit) } \\
\text { Symphoricarpos spp. (Leaves) } \\
\text { Tragopogon dubius (Buds) } \\
\text { Unidentified Forbs } \\
\text { Unidentified Grass }\end{array}$ & $\begin{array}{l}-\overline{4} / 5 d \\
40 / 5 \\
-\overline{2} \\
20 / 3 \\
60 / 7 \\
- \\
100 / 22 \\
60 / 1 \\
-\overline{1} 121 \\
\overline{-} \\
60 / 2 \\
20 / \operatorname{tr} \\
40 / \operatorname{tr} \\
80 / \operatorname{tr} \\
100 / 1 \\
\end{array}$ & $\begin{array}{c}17 / 1 \\
- \\
- \\
100 / 60 \\
33 / \operatorname{tr} \\
\overline{17 /} 1 \\
17 / \operatorname{tr} \\
17 / \operatorname{tr} \\
33 / 1 \\
67 / 4 \\
33 / 1 \\
33 / 5 \\
- \\
17 / \operatorname{tr} \\
33 / 1 \\
50 / 4 \\
\end{array}$ & $\begin{array}{l}- \\
\overline{20 / t r e} \\
40 / 6 \\
40 / 2 \\
- \\
- \\
80 / 15 \\
20 / 11 \\
- \\
20 / 1 \\
- \\
40 / 2 \\
20 / 1 \\
20 / 1 \\
20 / 1 \\
20 / \operatorname{tr}\end{array}$ & $\begin{array}{l}6 / \mathrm{tr} \\
12 / 1 \\
18 / 1 \\
47 / 23 \\
29 / 1 \\
18 / 2 \\
6 / \mathrm{tr} \\
65 / 12 \\
29 / 4 \\
12 / \mathrm{tr} \\
41 / 8 \\
12 / \mathrm{tr} \\
41 / 2 \\
12 / \mathrm{tr} \\
24 / 1 \\
47 / 1 \\
59 / 2\end{array}$ \\
\hline Tota $]$ & $100 / 67$ & $100 / 80$ & $100 / 40$ & $100 / 59$ \\
\hline
\end{tabular}

Animal llaterial:

Lepidoptera

Orthoptera

Tota 1

\begin{tabular}{|c|c|c|c|}
\hline $8 \overline{8} / 33$ & $\begin{array}{r}17 / \mathrm{tr} \\
100 / 20 \\
\end{array}$ & $\begin{array}{r}20 / 5 \\
100 / 55 \\
\end{array}$ & $\begin{array}{l}12 / 1 \\
94 / 38 \\
\end{array}$ \\
\hline $00 / 33$ & $100 / 20$ & $100 / 60$ & 100 \\
\hline
\end{tabular}

a

Includes only those taxa occurring at a level of at least 0.5 percent during at least one year in which samples were taken.

b Includes one sample taken during 1979.

c Number of samples.

d Frequency (percent occurrence among samples)/average percent of diet.

e $t r$ - trace ( a value less than 0.5 percent). 
near normal (Appendix Table 1). Precipitation was below normal in May 1977 while average monthly temperature was above normal. These conditions may have influenced the difference in production between years, although it was more likely that the comparative abundance of concealing herbaceous cover in 1978, as opposed to its comparative absence in 1977, may have hindered observability of young turkeys during summer 1978. Knapp (1979) reported a phenomenally high level of harvest and hunter success in Carter County in 1978 which would have suggested good reproductive success during that year.

No attempt was made to determine numbers of turkeys on the study area. It is noteworthy that Jonas (1966) observed 468 groups of turkeys from 1961-63 while only 52 groups were observed during this three-year study. However, the level of effort to specifically locate turkeys during this study was undoubtedly less than that of Jonas. In any event, all groups observed during this study were documented. It is entirely ikely that present population numbers are lower than those of the early 1960's. Populations of turkeys now also occur in neighboring areas such as the Ekalaka Hills, Chalk Buttes, Boxelder Creek and the Little Missouri River. Since turkeys were not established in those areas by the Department, it is likely those populations became established through birds emigrating from the Long Pines.

\section{Sharp-tailed Grouse}

\section{Distribution}

Sharp-tailed grouse occurred primarily in the lower, nontimbered portions of the major drainages in the study area (Figure 23). They were mostly associated with prairie grasslands, agricultural areas and riparian tree/shrub sites. Eight breeding areas (leks) were found during the course of the study of which only 2 occurred within the boundary of the national forest.

Lek (1) occurred on the west side of Snow Creek (Figure 23) on a grassland terrace above the flood plain on the national forest. Males displayed on this lek, or dancing ground, during spring of 1977-79. During the 3 respective years, 18, 10 and 16 males were observed displaying at this lek.

Lek (2) was located along Middle Slick Creek east of the Rustler Divide (Figure 23) on a nearly level hay meadow. It was occupied each spring during the study.

Lek (3) was located in South Slick Creek in an abandoned hay meadow. Sharptails were observed on the ground displaying only during 1977. Males were heard displaying in that general vicinity during April 1979, but the area where they were displaying was not located.

Males were observed displaying on lek (4) only during spring 1977. It was on a reservoir dike, which was nearly devoid of vegetation, along Tie Creek (Figure 23). Six to 10 males were observed on that ground. 


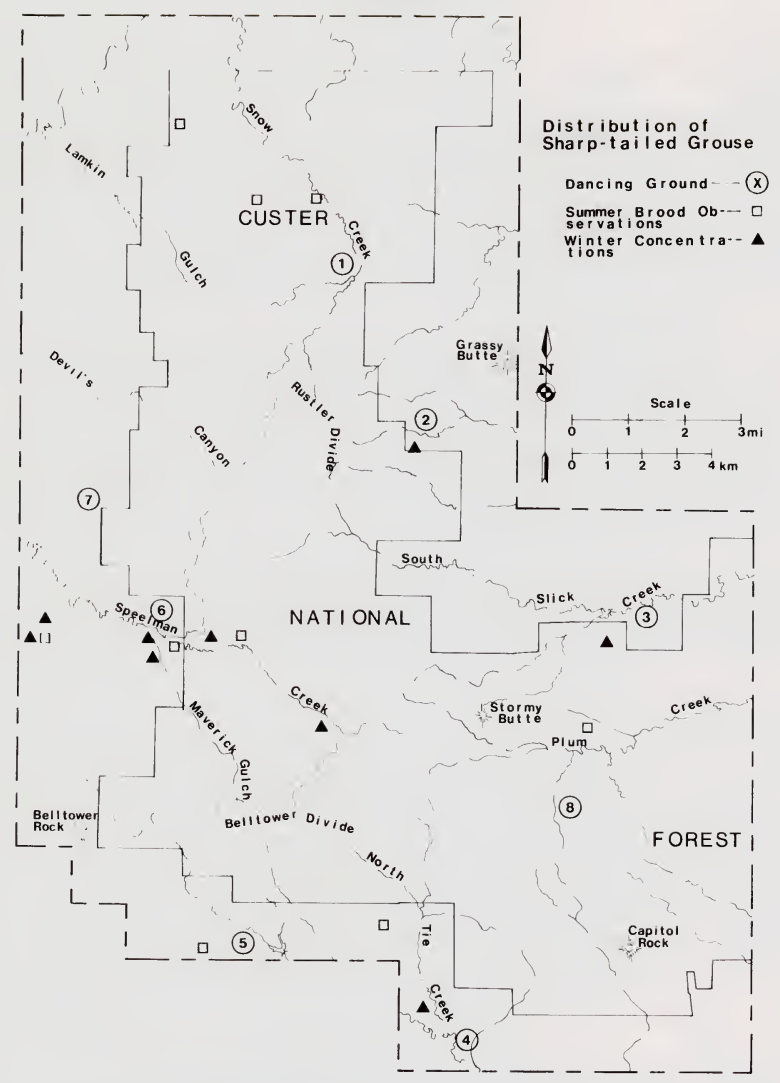

Figure 23. Location of sharp-tailed grouse dancing grounds and winter concentrations in the Long Pines study area. 
Lek (5), which was also located along the floodplain of Tie Creek, was occupied by breeding males during each year of this study. It was located on a hay meadow and adjoining cultivated field just south of the national forest boundary. It was consistently used by a larger number of grouse than other dancing grounds observed during the study. From 1977-79, 20 to 30 birds were observed on this ground, al though it was not determined exactly what proportion were breeding males.

Lek (6) occurred on Speelman Creek just west of national forest boundary (Figure 23). Grouse also displayed on a hay meadow at this site but shifted the site of their activity in response to plowing and harrowing by the landowner. Breeding males used the area during each vear of the study.

Lek (7) was located just outside the national forest boundary north of Speelman Creek in a hay meadow. Sharp-tailed grouse were observed there only during 1977. The landowner reported having seen sharptails displaying there during years previous to 1977.

Lek (8) was located during April 1979. It occurred on a grassy knoll within a private inholding along Plum Creek (Figure 23). Personnel of the Department of Fish, Wildlife and Parks reported a dancing ground in that vicinity during years prior to this study.

It is very likely that all dancing grounds within the study area were not found during the study. Sharptails were observed in the extreme northeast corner of the study area during April 1979 but a ground was not located. Courtship activity could be heard in the Lamkin Gulch area during the same year but a ground was not located there either.

\section{Fall Food Habits}

Crops from 14 hunter-killed sharp-tailed grouse were obtained during 1976, 1978 and 1979. Plant and animal material averaged 85 and 15 percent, respectively, of the sample (Table 29). Major plant material used by sharptails during that season included fruit from silver buffaloberry, fleshy hawthorn, wild rose and horizontal juniper. Their combined use consitituted 60 percent of the seasonal diet. Herbaceous material accounted for an additional 10 percent. Animal material fed upon by sharptails consisted almost exclusively of grasshoppers (Orthoptera). Fall food habits of sharp-tailed grouse in the Long Pines study area generally reflected use of grassland, agricultural and riparian tree/ shrub habitat.

\section{Miscellaneous Sightings of Small Game}

Hungarian partridge (Perdix perdix) were occasionally sighted near the periphery of the national forest. Nearly all were sighted in prairie grasslands and agricultural areas. Sage grouse (Centrocercus urophasianaus) were observed in sagebrush-grasslands outside the study area during winter. One sage grouse was observed in the extreme northeast corner of the Long Pines during October 1978 in a large grassland park. 
DuBois (1979) listed several species of ducks observed on the study area during summer 1977 and spring and summer 1978. These were largely associated with man-made impoundments in the study area and included mallards (Anas platyrhynchos), gadwalls (A. strepera), pintails (A. acuta), green-winged teal (A. carolinensis), blue-winged teal (A. discors), American wigeon (Mareca americana) and shovelers (Spatula clypeata). A mallard hen was observed with a brood on a pond in the extreme northeast corner of the study area during July 1977.

Table 29. Fall foods of sharp-tailed grouse in the Long Pines study area during 1976-79 as determined from analys is of crop contents of 14 hunterkilled birds.

\begin{tabular}{ccccc}
\hline & 1976 & 1978 & 1979 & A11 Years \\
Taxa & $3^{\mathrm{b}}$ & 2 & 9 & 14 \\
\hline
\end{tabular}

Plant Material:

$\begin{array}{lcccr}\text { Antennaria parvifolia (Leaves) } & 33 / 1 \mathrm{C} & 50 / 2 & 11 / 1 & 21 / 1 \\ \text { Berberis repens (Fruit) } & - & 50 / 30 & 11 / 2 & 14 / 5 \\ \text { Crataegus succulenta(Fruit) } & 33 / 18 & 50 / 2 & 44 / 24 & 43 / 20 \\ \text { Hordeum vulgare (Seeds) } & - & - & 11 / 4 & 7 / 2 \\ \text { Juniperus horizontalis (Fruit) } & - & 50 / 22 & - & 7 / 5 \\ \text { Leguminosae (Leaves) } & - & - & 11 / 1 & 7 / 1 \\ \text { Linum rigidum (Seeds) } & - & - & 22 / 1 & 14 / 1 \\ \text { Medicago sativa (Leaves) } & - & - & 11 / 7 & 7 / 5 \\ \text { Pinus ponderosa(Seeds) } & - & 50 / 7 & - & 7 / 1 \\ \text { Rhus trilobata (Fruit) } & - & - & 22 / 1 & 14 / 1 \\ \text { Rosa spp. (Fruit) } & 67 / 47 & 50 / 2 & - & 21 / 10 \\ \text { Shepherdia argentea (Fruit) } & - & - & 56 / 38 & 36 / 25 \\ \text { Symphoricarpos spp. (Fruit) } & 33 / 4 & 100 / 10 & 11 / \operatorname{tr} & 29 / 2 \\ \text { Taraxicum officinale (Leaves) } & 67 / 3 & 50 / \operatorname{tr} & 22 / \operatorname{tr} & 36 / 1 \\ \text { Tragopogon dubius (Buds) } & - & 100 / 2 & 11 / \operatorname{tr} & 21 / \operatorname{tr} \\ \text { Tragopogon dubius (Leaves) } & 33 / 14 & - & 11 / \operatorname{tr} & 21 / 3 \\ \text { Unidentified Grass } & 100 / 1 & - & 11 / \operatorname{tr} & 29 / \operatorname{tr} \\ \text { Unidentified Forbs } & 100 / 10 & 100 / 2 & 44 / \operatorname{tr} & 64 / 2 \\ \quad \text { Total } & 100 / 98 & 100 / 90 & 100 / 79 & 100 / 85\end{array}$

Animal Material:

Coleoptera

Orthoptera

$\begin{array}{ll}67 / 2 & - \\ \overline{67 / 2} & \frac{50 / 10}{50 / 10}\end{array}$

29/ 1

$36 / 14$

Tota 1

a

Includes only those taxa occurring at a level of at least 0.5 percent during at least one year in which samples were taken.

b Number of samples

c Frequency (percent occurrence among samples)/average percent of diet.

d $t r$ - trace ( a value less than 0.5 percent). 


$$
\text { Nongame Wildlifel' }
$$

Little information has been gathered on nongame wildlife of southeastern Montana as compared to most other regions of the state. Early work on birds cons isted of regional annotated species 1ists (Cameron 1907, Saunders 1916, Visher $1911,1912,1913)$. Few species listed were specifically associated with the Long Pines. Skaar (1975) listed 151 species of birds for the latilong containing the Long Pines which was based on the above research and from recent observations.

Avifauna have been inventoried in other areas of southeastern Montana, which contain some habitat similar to that of the Long Pines (Pettingill and Whitney 1965, Swenson 1978, Mathews 1979). Herbert (1977) and Hickey and Mikol (1979) estimated breeding bird densities in areas on Sarpy Creek and near Decker, Montana respectively. Scientific names of birds are listed in Table 30 .

Nongame mammals have received less attention than birds in the area. Jones et al. (1973) described the bats of southeastern Montana with many references to the Long Pines. Lampe et al. (1974) described the mammals of Carter County after several visits to the area. Many of their traplines were located within the Long Pines. Scientific names appear in Table 31.

One hundred and fourteen species of birds were observed on the study area during two field seasons (June-August 1977. April-September 1978) and several later visits (DuBois 1979). Table 30 summarizes the status, abundance and habitat use of raptors and nongame birds. The Cooper's hawk, Swa inson's hawk, ferruginous hawk, golden eagle, bald eagle, prairie falcon, merlin, long-billed curlew, upland sandpiper, burrowing owl, mountain bluebird, and field sparrow were 1 isted by Flath (1979) as species of special interest or concern in Montana.

Forty species of mammals occurred in the study area, according to Lampe et al. (1974) and our observations. This list is undoubtedly incomplete. Table 31 summarizes the abundance and habitat use of the nongame mammals. The abundance and habitat use information was mostly derived from Lampe et a1. (1974), Jones et al. (1973), and Hoffman and Pattie (1968). Merriam's shrew, long-legged myotis, Townsend's big-eared bat, hispid pocket mouse, and meadow jumping mouse were 1 isted by Flath (1979) as species of special interest or concern.

\section{Raptors}

Turkey vultures were one of the most commonly observed raptors in the study area (Allen 1979). One nest, found $9 \mathrm{miles}(15 \mathrm{~km})$ northwest of the study are in 1978, suggested the likeliness that they nested in the Long Pines also. Possible nesting sites in the Long Pines included caves, hollow logs and stumps, and old sheds and barns.

I/ Prepared by Kristi DuBois. 
Table 30. Status, abundance and habitat use of the nongame birds in the Long Pines (Nomenclature follows the A.O.V. checklist (1957) and supplements.

\begin{tabular}{|c|c|c|c|c|c|c|c|c|c|c|c|c|}
\hline Common Name & Scientific Name & Status & Abund. & A & $G$ & GP & $S G$ & $\mathrm{BB}$ & $R$ & PXS & PMS & RTS \\
\hline $\begin{array}{l}\text { Turkey vulture } \\
\text { Sharp-shinned hawk } \\
\text { Cooper's hawk } \\
\text { Red-tailed hawk } \\
\text { Swainson's hawk } \\
\text { Rough-legged hawk } \\
\text { Ferruginous hawk } \\
\text { folden eaqle } \\
\text { Bald eaqle } \\
\text { Marsh hawk } \\
\text { Prairie falcon } \\
\text { Merlin } \\
\text { American kestrel } \\
\text { American coot } \\
\text { Killdeer } \\
\text { Long-billed curlew } \\
\text { Upland sandpiper } \\
\text { Spotted sandpiper } \\
\text { Solitary sandpiper } \\
\text { Greater yellowleqs } \\
\text { Willet } \\
\text { Wilson's phalarope } \\
\text { Rock dove } \\
\text { Mourning dove } \\
\text { Black-billed cuckoo } \\
\text { Great-horned owl } \\
\text { Burrowing owl } \\
\text { Short-eared owl } \\
\text { Poor-will } \\
\text { Common nighthawk } \\
\text { White-throated swift } \\
\text { Belted kingfisher } \\
\text { Common flicker } \\
\text { Red-headed woodpecker } \\
\text { Hairy woodpecker }\end{array}$ & $\begin{array}{l}\text { Cathartes aura } \\
\text { Accipiter striatus } \\
\text { Accipiter cooperii } \\
\text { Buteo jamaicensis } \\
\text { Buteo swainsoni } \\
\text { Buteo lagopus } \\
\text { Buteo regalis } \\
\text { Aquila chrysaetos } \\
\text { Haliaeetus leucocephalus } \\
\text { Circus cyaneus } \\
\text { Falco mexicanus } \\
\text { Falco columbarius } \\
\text { Falco sparverius } \\
\text { Fulica americana } \\
\text { Charadrius vociferus } \\
\text { Numenius americanus } \\
\text { Bartramia longicauda } \\
\text { Actitis macularia } \\
\text { Tringa solitaria } \\
\text { Tringa melanoleuca } \\
\text { Catoptrophorus semipalmatus } \\
\text { Steganopus tricolor } \\
\text { Columba livia } \\
\text { Zenaida macroura } \\
\text { Coccyzus erythropthalmus } \\
\text { Bubo virginianus } \\
\text { Athene cunicularia } \\
\text { Asio jlammeus } \\
\text { Phalaenoptilus nuttallii } \\
\text { Chordeiles minor } \\
\text { Aeronautes saxatalis } \\
\text { Megacer!le alcyon } \\
\text { Colaptes auratus } \\
\text { Pelanerpes erythrocephalus } \\
\text { Picoides villosus }\end{array}$ & $\begin{array}{l}\text { b } \\
B \\
B \\
B \\
t \\
W \\
t \\
B \\
W \\
B \\
B \\
B \\
B \\
M, b \\
B \\
b \\
b \\
b \\
M \\
M \\
M \\
M, b \\
b \\
B \\
b \\
B \\
\text { D } \\
B \\
b \\
b \\
B \\
B \\
B \\
B \\
B \\
B\end{array}$ & $\begin{array}{l}C \\
U \\
U \\
C \\
R \\
U \\
R \\
U \\
R \\
C \\
C \\
U \\
A \\
U \\
C \\
R \\
U \\
U \\
R \\
R \\
R \\
U \\
C \\
A \\
U \\
C \\
R \\
R \\
C \\
C \\
C \\
U \\
C \\
U \\
C\end{array}$ & $\begin{array}{l}X \\
X \\
X\end{array}$ & $\begin{array}{l}X \\
X \\
X \\
X \\
X \\
X \\
X \\
X\end{array}$ & $\begin{array}{l}X \\
X \\
X \\
X \\
X \\
X\end{array}$ & $\begin{array}{l}X \\
X \\
X \\
X\end{array}$ & $\begin{array}{l}x \\
x \\
x\end{array}$ & $\begin{array}{l}x \\
x\end{array}$ & $\begin{array}{l}X \\
X \\
X \\
X\end{array}$ & $\begin{array}{l}X \\
X \\
X \\
X\end{array}$ & $\begin{array}{l}x \\
X \\
X \\
X \\
x\end{array}$ \\
\hline
\end{tabular}


Table 30. Continued

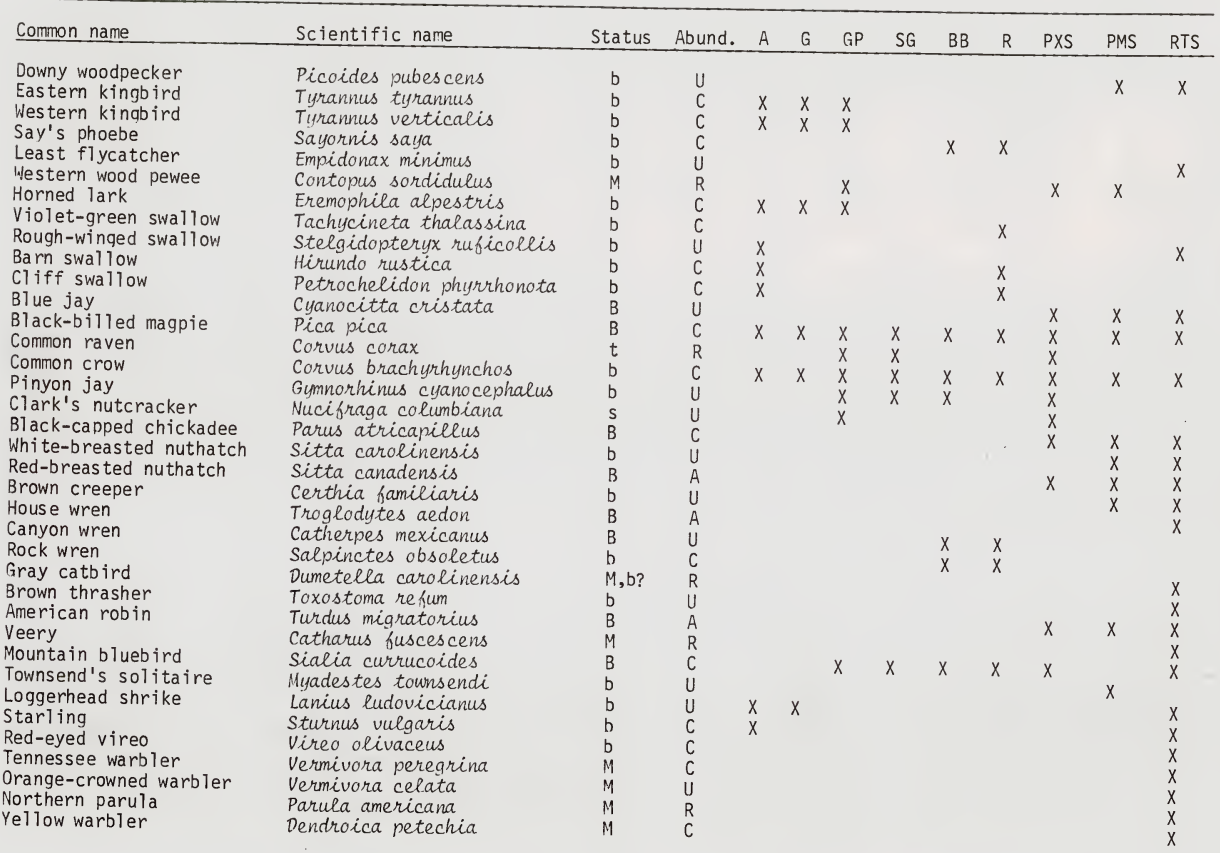


Table 30. Continued.

\begin{tabular}{|c|c|c|c|c|c|c|c|c|c|c|c|c|}
\hline Common name & Scientific name & Status & Abund. & A & G & GP & SG & $B B$ & $\mathrm{R}$ & PXS & PMS & RTS \\
\hline Yellow-rumped warbler & Dendroica coronata & $b$ & A & & & & & & & $x$ & $x$ & $x$ \\
\hline Blackpoll warbler & Dendroica striata & $M$ & $\mathrm{R}$ & & & & & & & & $\wedge$ & $\hat{x}$ \\
\hline Ovenbird & Seiurus aurocapillus & B & A & & & & & & & & $x$ & $x$ \\
\hline Common yellowthroat & Geothl !pis trichas & $b$ & A & & & & & & & & & $\hat{x}$ \\
\hline Yellow-breasted chat & Icteria virens & & U & & & & & & & & & $\ddot{x}$ \\
\hline American redstart & Setophaga ruticilla & $M, b ?$ & $\mathrm{C}$ & & & & & & & & & $x$ \\
\hline House sparrow & Passer domesticus & b & C & $x$ & & & & & & & & $x$ \\
\hline Western meadowlark & Sturnella neglecta & B & A & $x$ & $x$ & $x$ & $x$ & $x$ & & & & \\
\hline $\begin{array}{l}\text { Red-winged blackbird } \\
\text { Northern oriole }\end{array}$ & $\begin{array}{l}\text { Agelaius phoeniceus } \\
\text { Icterus galbula }\end{array}$ & & U & $x$ & $x$ & & & & & & & $\begin{array}{l}x \\
y\end{array}$ \\
\hline Brewer's blackbird & Euphagus cyanocephalus & $b$ & $\mathrm{C}$ & & & & & & & $x$ & $x$ & $\begin{array}{l}X \\
X\end{array}$ \\
\hline Common grackle & Ouiscalus quiscula & $b$ & C & & & & & & & & & $\hat{x}$ \\
\hline Brown-headed cowbird & Molothrus ater & $b$ & C & $x$ & $x$ & $x$ & $x$ & $x$ & $x$ & $x$ & $x$ & $x$ \\
\hline Western tanager & Piranga ludoviciana & $b$ & $\mathrm{C}$ & & & & & & & $x$ & $x$ & \\
\hline Black-headed grosbeak & Pheucticus melanocephalus & $b$ & U & & & & & & & & & $x$ \\
\hline Indigo bunting & Passerina cyanea & b & U & & & & & & & & & $x$ \\
\hline & Passerina amoena & $b$ & C & & & & & & & & & $x$ \\
\hline $\begin{array}{l}\text { Evening grosbeak } \\
\text { Pine siskin }\end{array}$ & $\begin{array}{l}\text { Hesperiphona vespertina } \\
\text { carduelis pinus }\end{array}$ & & U & & & & & & & & & $x$ \\
\hline American goldfinch & & $\begin{array}{l}M, b ? \\
b\end{array}$ & $\begin{array}{l}\mathrm{R} \\
\mathrm{C}\end{array}$ & & & & & & & $x$ & $x$ & \\
\hline Red crossbill & Loxia curvirostra & B & $\begin{array}{l}C \\
A\end{array}$ & & & $x$ & & & & $x$ & & $x$ \\
\hline Rufous-sided towhee & Pipilo erythrophthalmus & $b$ & $\begin{array}{l}A \\
A\end{array}$ & & & & & & & $x$ & $x$ & $x$ \\
\hline Lark buntinq & Calamospiza melanocorys & $b$ & U & $x$ & $x$ & $x$ & $x$ & & & & & \\
\hline Savannah sparrow & Passerculus sandwichens is & M & U & $x$ & $x$ & & & & & & & \\
\hline Grasshopper sparrow & Ammodramus savannarum & b & C & & $x$ & $x$ & & & & & & \\
\hline Vesper sparrow & Pooecetes gramineus & $b$ & A & $X$ & $x$ & $x$ & $x$ & $x$ & & & & \\
\hline Lark sparrow & Chondestes grammacus & $b$ & C & & & $x$ & & & & $x$ & & $x$ \\
\hline $\begin{array}{l}\text { Dark-eyed Junco (white- } \\
\text { winged race) }\end{array}$ & Junco hyemalis & B & C & & & & & & & & $x$ & $\hat{x}$ \\
\hline Chipping sparrow & Spizella passerina & B & A & & & $x$ & & $x$ & $x$ & & $x$ & $X$ \\
\hline Field sparrow & Spizella pusilla & $b$ & $\mathrm{U}$ & & $x$ & $x$ & & & & & & $\hat{x}$ \\
\hline Song sparrow & Melospiza melodia & b & $\mathrm{U}$ & & & & & & & & & $x$ \\
\hline
\end{tabular}


Status: B - definite evidence of breeding (active nest, dependent young)

b - circumstantial evidence of breeding (present during breeding season, defending territory).

s - summer resident, no evidence of breeding

$t$ - transient through the study area

W - winter resident only

$M$ - migrant only

b?- not observed during breeding season, but nesting likely in or near the study area.

Abundance: A - abundant in appropriate habitats

C - common

$U$ - uncommon

$\mathrm{R}$ - rare

Habitat Groups: A - Agricultural (hay or grain fields)

B - Grasslands (surrounding Long Pines)

GP - Grassland Parks

$S G$ - Sagebrush-grassland

$B B$ - Badland Breaks

$R$ - Rimrock and cliffs

PXS - Ponderosa pine-xeric grassland-shrub

PMS - Ponderosa pine-mesic shrub

RTS - Riparian Tree - shrub 
Table 31. Abundance and habitat occurrence (when known) of nongame mammals in the Long Pines.

\begin{tabular}{|c|c|c|}
\hline $\begin{array}{l}\text { 1. Masked shrew } \\
\text { 2. Merriam shrew } \\
\text { 3. Long-eared bat } \\
\text { 4. Small-footed myotis } \\
\text { 5. Little brown myotis } \\
\text { 6. Long-legged myotis } \\
\text { 7. Silver-haired bat } \\
\text { 8. Big brown bat } \\
\text { 9. Hoary bat } \\
\text { 10. Townsend's big-eared bat } \\
\text { 11. White-tailed jackrabbit } \\
\text { 12. Desert cottontail } \\
\text { 13. Eastern cottontail } \\
\text { 14. Least chipmunk } \\
\text { 15. Thirteen-lined ground squirrel } \\
\text { 16. Red squirrel } \\
\text { 17. Northern pocket gopher } \\
\text { 18. Muskrat } \\
\text { 19. Hyoming pocket mouse } \\
\text { 20. Hispid pocket mouse } \\
\text { 21. Beaver } \\
\text { 22. Hestern harvest mouse } \\
\text { 23. Deer mouse } \\
\text { 24. Bushy-tailed woodrat } \\
\text { 25. Prairie vole } \\
\text { 26. Meadow vole } \\
27 . \text { House mouse } \\
\text { 28. Meadow jumping mouse } \\
\text { 29. Porcupine } \\
\text { 30. Coyote } \\
\text { 31. Red fox } \\
\text { 32. Raccoon } \\
\text { 33. Long-tailed weasel } \\
\text { 34. Mink } \\
\text { 35. Striped skunk } \\
\text { 36. Bobcat }\end{array}$ & $\begin{array}{l}\text { Sorex cinereus } \\
\text { Sorex merriami } \\
\text { Myotis evotis } \\
\text { Myotis leibii } \\
\text { Myotis lucifugus } \\
\text { Myotis volans } \\
\text { Lasionycteris noctivagans } \\
\text { Eptesicus fuscus } \\
\text { Lasiurus cinereus } \\
\text { Plecotus townsendii } \\
\text { Lepus townsendii } \\
\text { Sylvilagus audubonii } \\
\text { Sylvilagus floridanus } \\
\text { Eutamias minimus } \\
\text { Spermophilus tridecemlineatus } \\
\text { Tamiasciurus hudsonicus } \\
\text { Thomomys talpoides } \\
\text { Ondatra zibethicus } \\
\text { Perognathus fasciatus } \\
\text { Perognathus hispidus } \\
\text { Castor canadensis } \\
\text { Reithrodontomys megalotis } \\
\text { Peromyscus maniculatus } \\
\text { Neotoma cinerea } \\
\text { Microtus ochrogaster } \\
\text { Microtus penns ylvanicus } \\
\text { Mus musculus } \\
\text { Zapus hudsonius } \\
\text { Erethizon dorsatum } \\
\text { Canis latrans } \\
\text { Vulpes vulpes } \\
\text { Procyon lotor } \\
\text { Mustela frenata } \\
\text { Mustela vison } \\
\text { Mephitis mephitis } \\
\text { Lynx rufus }\end{array}$ & $\begin{array}{l}\text { common in forested mesic habitats } \\
\text { rare, grasslands and sagebrush } \\
\text { common, coniferous forests } \\
\text { forests } \\
\text { common, forests } \\
\text { common, forests } \\
\text { common } \\
\text { common } \\
\text { forests } \\
\text { rare } \\
\text { grasslands, common, but population fluctuates } \\
\text { grass lands, pine ridges } \\
\text { riparian habitat } \\
\text { common, pine ridges, badlands } \\
\text { common, grasslands } \\
\text { common, pine forests } \\
\text { common, grasslands } \\
\text { ponds surrounding the Long Pines } \\
\text { common, grasslands } \\
\text { rare, grass lands } \\
\text { common in many drainages } \\
\text { uncommon, dense grassland } \\
\text { abundant, all habitats } \\
\text { common, abandoned buildings, cliffs } \\
\text { common, grassland parks } \\
\text { abundant, grasslands, riparian habitat } \\
\text { common near human habitations } \\
\text { riparian habitats } \\
\text { common, pine forests } \\
\text { common } \\
\text { common } \\
\text { common near springs and campgrounds } \\
\text { common } \\
\text { common } \\
\text { common } \\
\text { uncommon }\end{array}$ \\
\hline
\end{tabular}


Sharp-shinned hawks were occasionally observed in the Long Pines, and recently fledged young were observed in 1977 (Allen 1979). They preferred dense stands of trees with a well-developed canopy for nesting and were observed hunting in both forests and grassland parks. The status of their numbers was hard to determine due to poor observability in dense forests.

Cooper's hawks were observed more often than sharp-shinned hawks (Allen 1979). Two active nests were found, one each in 1977 and 1978, in fairly dense stands of ponderosa pine. Cooper's hawks were observed hunting in forests and grassland parks.

Red-tailed hawks were distributed throughout the study area although few nests were found. Numerous observations suggested many pairs may nest in the study area. All nests were in ponderosa pine, mostly along ridges or cliffs near grassland parks (Allen 1979).

Twenty golden eagle nests were found, of which one was active in 1977 and four were active in 1978. Seventeen nests occurred on cliffs and three in ponderosa pine (Allen 1979). Golden eagles are known to sometimes use alternate nest sites in different years, so some of the inactive nests may be used regularly (Call 1978).

Bald eagles and rough-legged hawks were observed wintering on the study area. Several bald eagles probably winter in the Long Pines each year, but an area south of the Long Pines is thought to be a traditional wintering ground for bald and golden eagles. Twelve bald eagles were observed by aerial survey during winter 1979-80, one on Boxelder Creek, and 11 along the Little Missouri River. Seventy-one golden eagles were also observed in the 1,149 square mile $\left(2,976 \mathrm{~km}^{2}\right)$ area (antelope hunting districts 781 and 782 ) containing the Little Missouri River (Swenson 1980).

Marsh hawks were commonly seen hunting in grassland parks. One nest was found in 1978 in a snowberry draw running through a small grassland park. Several other nests were found in similar habitat on nearby tracts of national forest lands.

Kestrels were the most abundant raptor in the study area. Several nests were located in ponderosa pine snags, and one was located on a cliff approximately 50 feet $(15 \mathrm{~m})$ from an active prairie falcon nest (Allen 1979). They were often observed along cliffs and ridges, possibly due to both high availability of snags and proximity to grassland parks. Kestrels used grasslands, roadsides, and grassland parks for hunting.

Several merlins nested in abandoned magpie nests in ponderosa pine. All were found within the study area and on nearby national forest land. All were within $0.3 \mathrm{mile}(0.5 \mathrm{~km})$ of grasslands (Allen 1979). This species seemed to be the least abundant falcon, although difficulty in locating nests made population estimates impractical. 
Fourteen prairie falcon aeries were located in holes or on ledges on cliffs, by the end of 1978 (Allen 1979). Twelve were occupied in 1978, indicating that numbers of prairie falcons may have been limited by the number of suitable sites for aeries.

Great-horned owls were commonly observed, and a nest was found near the study area. They are known to nest in abandoned hawk, crow, and magpie nests; hollow trees; and potholes and ledges on cliffs.

Description by Habitat Group - Birds

\section{Riparian Tree-Shrub}

This habitat group supported the highest breeding bird density (413 pairs) $100 \mathrm{ha}$ ) and species diversity (38 species), due to a highly diverse fol iage structure (MacArthur and MacArthur 1961), high diversity of tree and shrub species, and high availability of water (DuBois 1979). Species composition and breeding bird density varied with the type of vegetation present. Snowberry draws supported comparatively low numbers of individuals and species of birds suggesting such sites were too xeric. Snowberry draws were heavily favored by vesper sparrows over surrounding grasslands, and served as important nesting areas for marsh hawks.

Aspen supported comparatively high breeding densities and numbers of birds. Species composition and breeding density in aspen was similar to that of ponderosa pine forests, with which they are usually associated (DuBois 1979). Ovenbirds were comparatively abundant in aspen draws and probably preferred them for nesting areas. Red-breasted nuthatches, blackcapped chickadees, dark-eyed juncos, and downy woodpeckers also seemed to favor aspen draws.

Boxelder-ash draws supported the highest diversity of bird species, breeding density, and number of unique species of all riparian habitat as well as all communities in the study area (DuBois 1979). Black-billed cuckoos, least flycatchers, house wrens, common yellowthroats, yellowbreasted chats, black-headed grossbeaks, lazuli buntings, and indigo buntings were species suspected to breed only in boxelder-ash draws. Other species breeding in this habitat were black-capped chickadees, rufous-sided towhees, red-breasted nuthatches, American robins, red-eyed vireos, and American goldfinches. The only blue jay nest found in the study area occurred in this habitat. Tennessee warblers, orange-crowned warblers, a blackpoll warbler and a parula warbler were also observed in boxelder-ash draws but were thought to be migrants. The blackpoll warbler was a rare migrant for the area and the parula warbler was the third record for the state of Montana. This habitat was also heavily used by migrating American robins, chipping sparrows, yellowrumped warblers, yellow warblers, and American redstarts.

Areas where boxelder and green ash gave way to plains cottonwood were not quantitatively sampled, but species composition was likely similar to boxelder-ash draws. Such habitat may support higher breeding bird densities 
than boxelder-ash draws. Swenson (1978a) found that creek bottom deciduous forests contained more species and higher numbers of birds than hardwood draws near the Yellowstone River.

Water impoundments located throughout the study area along draws and creek bottoms were important for nesting and migrating shorebirds such as spotted and upland sandpipers, willets, greater yellowlegs, solitary sandpipers, and Hilson's phalaropes. Belted kingfishers were found by water supporting small fish and frogs. Rough-winged swallows, barn swallows, cliff swallows, and violet-green swallows foraged for insects over ponds.

\section{Ponderosa Pine-Mesic Shrub}

of all types sampled this habitat group was the second-highest in breeding bird density ( 312 pairs/100 ha) and third-highest in species diversity (19 species) (DuBois 1979). Characteristic species were yellowrumped warblers, western tanagers, Townsend's solitaires, dark-eyed juncos, red crossbills, American robins, red-breasted nuthatches, black-capped chickadees, chippinq sparrows, and poor-wills. This was probably the most important nesting habitat for Cooper's hawks and sharp-shinned hawks. Ovenbirds were abundant in this habitat adjacent to aspen draws.

\section{Ponderosa Pine-Xeric Grassland-Shrub}

This habitat group supported the third-highest breeding bird density (109 pairs/100 ha) and second-highest species diversity ( 34 species) of the types sampled (DuBois 1979). Heavy interspersion of this type with grassland parks probably accounted for the high species diversity. Characteristic species included chipping sparrows, mountain bluebirds, mourning doves, lark sparrows, red crossbills, yellow-rumped warblers, black-billed magpies, common crows, and pinyon jays. This type was important for nesting redtailed hawks, merlins, and kestrels.

\section{Grassland Parks and Prairie Grasslands}

Grassland parks had the lowest breeding bird density (59 pairs/100 ha) and species diversity (11 species) of the types sampled (DuBois 1979). Western meadowlarks and vesper sparrows were the two most common species. Other species indigenous to grassland included grasshopper sparrows, horned larks, killdeers, and upland sandpipers. Grassland parks were important nesting areas for marsh hawks and hunting areas for all species of raptors.

The size of individual parks was important in determining species composition. Small parks of less than 40 acres ( $16 \mathrm{ha}$ ) usually only supported meadowlarks and vesper sparrows for grassland birds, but were used more by edge species such as chipping sparrows and lark sparrows. A pair of vesper sparrows successfully nested in a 20 acre ( 8 ha) grassland park, but a meadowlark singing in the same park disappeared in June 
apparently without nesting. Breeding bird densities in grassland parks appeared lower than breeding bird densities found by Hickey and Mikol (1979) near Decker, Montana. Grassland parks may have been marginal habitat for grassland birds.

Grassland surrounding the Long Pines supported more species than the grassland parks. Horned larks, upland sandpipers and killdeers were only found in the larger grassland parks in the Long Pines and were more common in the grasslands surrounding the Long Pines. Lark buntings, long-billed curlews, ferruginous hawks, and savannah sparrows were only observed in grasslands surrounding the Long Pines.

\section{Sagebrush-Grassland}

This habitat group was not quantitatively sampled, but contained most of the bird species found in grasslands. Western meadowlarks and vesper sparrows predominated. This habitat was likely used by raptors for hunting.

\section{Badland Breaks}

This habitat group was also not quantitatively sampled. Characteristic birds were 1 ikely western meadowlarks, vesper sparrows, and rock wrens in open areas; and mountain bluebirds, chipping sparrows and lark sparrows in areas with juniper.

\section{Rimrock-Cliffs}

This micro habitat occurred throughout the other habitats in the Long Pines, covered the smallest area, but served as important habitat for many bird species. Cliffs were the most important nesting substrate for prairie falcons, golden eagles, and probably great-horned owls and turkey vultures. Red-tailed hawks, merlins, and kestrels tended to locate their nests adjacent to cliffs due to the availability of large nest trees with a panoramic view, availability of old magpie and crow nests, and availability of snags. Mountain bluebirds and flickers were also more common adjacent to cliffs due to snags. Violet-green swallows, white-throated swifts, barn swallows, cliff swallows, rock wrens, Say's phoebes, canyon wrens, and common nighthawks also used cliffs for nesting.

\section{Description by Habitat Group - Mammals}

The lack of information on the mammals of the Long Pines prevented a detailed description by habitat group. Riparian habitat probably supported the highest densities of small mammals because of availability of water, cover, and food (especially insects). Matthews (1979) found a much higher trapping success in hardwood draw, mesic shrub, creek bottom, and reservoir areas than in upland grassland, grassland coulee, and xeric shrub areas near Wibaux, Montana. Water impoundments were very important feeding areas for bats (Jones et a1. 1973, Lampe et a1. 1974). Raccoons, beavers, muskrats, eastern cottontails, and masked shrews were also closely tied to water. 


\section{PART III - ANALYSIS OF HUNTING RECREATION}

Some of the major problems and issues facing outdoor recreationists in Montana (Montana Department Fish and Game 1978) include: an increasing human population and high rates of participation in outdoor recreation that are accelerating demands for wildlife oriented recreation (consumptive and nonconsumptive); expanding and intensifying uses of land and water resources that are diminishing the quality and quantity of wildlife habitat; and, decreasing public access for hunting on private and public lands. By 1990 Montana's human population is expected to approach one million people, or roughly an increase of 24 percent above that estimated for 1975. Southeastern Montana, which includes Fish, Wildlife and Parks Region 7, is expected to experience a human population increase of 22 percent from 1975 to 1990 (Montana Dept. Community Affairs, unpublished). With the exception of Powder River County, all counties throughout southeastern Montana experienced population declines from 1960-70 with the greatest declines occurring in the rural farm segment (Montana Dept. of Community Affairs 1975). Counties experiencing the greatest declines (13-14 percent) were the most sparsely populated and included Carter, Wibaux, Prairie and Treasure Counties. Future population increases in the region will undoubtedly be directly or indirectly related to energy development.

The U.S. Forest Service (1976b) addressed hunting oriented recreation in the Sioux District briefly under dispersed recreational activities. They did not anticipate any significant change in present use levels of developed recreational facilities (camp grounds, picnic grounds, etc.) or in levels of use in the dispersed category through 1986 due to the remoteness of tracts of national forest lands in the Sioux District. The management plan for developed facilities includes reduced maintenance.

Energy development in or near the Long Pines could potentially increase levels of recreational use of national forest lands from those experienced during recent years because of its public ownership with legal accessibility. Development on the forest itself could reduce present-day recreational values.

Hunter use of the Long Pines was analyzed during this study to determine present trends in hunter use and harvest. Trend data included origin of hunters, periods of comparatively heavy use, numbers of hunters, levels of hunting pressure and harvest. Only national forest lands in the study area were considered during this phase of study. Turkey and deer hunting during fall were the only types of hunting considered since these species appeared to attract hunters to the Long Pines. The turkey season usually opened during the third weekend in September, whereas the deer season opened the third or fourth weekend in October. Both seasons extended through the third or fourth weekend in November.

\section{Procedures}

Pneumatic traffic counters were placed at 3 of 6 entrances to the Long Pines during September 1976-78 prior to the opening of the fall turkey season. Counters were installed on Snow Creek, Speelman Creek and the southeast entrance below Capitol Rock. Readings were taken from the 
counters each Friday and Sunday evening throughout the fall hunting season to distinguish weekend from weekly hunter use. Trends in weekly use were monitored throughout a 9 week period in 1976 and 1978 and an 8 week period in 1977 when the early turkey season was only 4 weeks long compared to 5 weeks during the other 2 years. An attempt was also made to compare hunter use between years. Traffic counters were adjusted to advance one digit for each pair of axles passing over a pressure sensitive rubber hose stretched across the road at each entrance. Traffic indices reflected the count between any two given dates and data from all counters were eventually combined. No attempt was made to estimate the number of hunters from traffic counter data. Due to extenuating circumstances resulting in inaccurate readings from the counter on Snow Creek from livestock concentration in the area of the counter, all readings from that location were deleted from the final analysis.

Questionnaires were given to 282 hunting parties contacted in the Long Pines from 1976-79. Effort was made to contact as many parties as possible during the 4 years. More contacts were made on opening weekends than during other periods. One questionnaire was given to each party and information solicited involved all members of the party. The fall hunting season was arbitrarily split into 3 parts: early turkey season; first 2 weeks of the deer season; and, the last 2 weeks of the deer season. Hunters were asked to denote which period(s) they hunted. 0ther information solicited in the questionnaire included the number of hunters per party, whether they hunted turkeys, deer or both, the number of successful hunters, the number of days spent hunting turkeys and deer, species of deer harvested and sex of white-tailed deer harvested. Hunters were also asked to give the name of the town and state they were from. Since there was no way of knowing what proportion of the total number of parties hunting in the Long Pines were contacted, an upper limit of 75 percent was used as a constant for all years. From this the total number of hunters using the Long Pines each year from 1976-79 was estimated assuming that information returned by respondents was representative of all hunters. During 1978-79 hunters were asked (one response per party) to identify the single most important factor attracting them to the Long Pines and were offered a 7 ist of 4 choices. A fifth (blank) space was made available in case they hunted there for reasons not included among the choices offered. During the same period parties were also asked if mineral development in the Long Pines, regardless of its affect on the wildlife resource, would affect their decision to hunt there. Choices of yes, no and undecided were offered.

\section{Results and Discussion}

During the hunting seasons of 1976-79, 44 percent of 282 questionnaires were returned. Rates of response varied from 52 percent in 1976 to 35 percent in 1977. The number of hunters per party averaged 3.1 with only negligible differences observed between resident and non resident hunting parties. 


\section{Hunter Origin}

Sixty-four percent of 369 hunters from 122 responding parties were residents of Montana (Table 32) of which more than two-thirds were from Region 7 (southeastern Montana). Of hunters from within Region 7, 60 percent were from Fallon County (27 percent of all responding hunters) which neighbors Carter County to the north. Baker, the Fallon County seat with a population of about 2,500 people lies within 60 miles $(97 \mathrm{~km})$ of the Long Pines. Residents of Carter County accounted for only one percent of all responding hunters. Since Carter County is rural and sparsely populated, local residents usually hunt on their own land or have easy access to other private lands, and as a rule, probably do not hunt on national forest lands.

Table 32. Origin of 369 hunters from 122 parties responding to questionnaires distributed during fal1 hunting seasons of 1976-79.

Residents:

Region $7^{a}$

Outside Region 7

Nonresidents:

Upper Midwest ${ }^{b}$

Other States

a Included hunters from Carter, Custer, Fallon, Dawson and Richland counties.

b Included hunters from Indiana, Iowa, Michigan, Minnesota, North Dakota, South Dakota and Wisconsin.

Nonresident hunters came primarily from the Midwest (Table 32). Sixtytwo percent of all nonresident parties responding to the questionnaire came from Minnesota and Wisconsin. In spite of the remoteness of the Long Pines from human population centers in and out of Montana, 99 percent of the hunters from al1 responding parties were from outside of Carter County, and 55 percent were from outside of Region 7 .

\section{Timing of Hunter Usage}

Forty-six percent of responding resident hunters hunted only turkeys, 27 percent hunted only deer and 27 percent hunted both turkeys and deer. of responding nonresident hunters, 5, 60 and 35 percent fell within the 
3 respective categories. Nearly half the residents hunted in the Long Pines during the early turkey season prior to the opening of the deer season, whereas the heaviest nonresident use occurred during the first 2 weeks of the deer season (Table 33). Data from questionnaires indicated the greatest proportion of all hunters (48 percent) hunted the first 2 weeks of the deer season (Table 33), but data from traffic counters indicated the highest seasonal use during the early part of turkey season (Table 34). This may be explained by the fact that many resident hunters hunting on the opening weekend of the turkey season, mostly those from Baker, were also observed hunting in the Long Pines during subsequent weekends.

Data from traffic counters indicated peak use during the first week of the turkey season and an even higher peak during the first 2 weeks of the deer season (Figure 24). Sharp declines in traffic indices from one week to the next were often associated with adverse weather conditions.

Table 33. Hunter use during 3 periods of the hunting season by resident and nonresident hunters as determined from questionnaires from 1976-79.

\begin{tabular}{lccc}
\hline & $\begin{array}{c}\text { tarly } \\
\text { Turkey Season } \\
(4-5 \text { weeks) }\end{array}$ & $\begin{array}{l}\text { Perioda } \\
\text { Deer Sea Son } \\
\text { (2 weeks) }\end{array}$ & $\begin{array}{l}\text { Second Half } \\
\text { Deer Season } \\
\text { (2 weeks }\end{array}$ \\
\hline Residents (234) c & $48^{b}$ & 35 & 17 \\
Nonresidents (131) & 6 & 72 & 22 \\
A11 Hunters & 33 & 48 & 19 \\
\hline
\end{tabular}

a Some hunters hunted more than one period as indicated by questionnaires.

b Percent of sample.

c Number of hunters responding to questionnaires.

For example, the comparatively low index during the second week of the early part of turkey season in early 0ctober 1977 coincided with abnormally cool rainy weather which occurred mostly during the weekend. Traffic dropped off sharply during the third week of the deer season in mid-November 1978 which followed a major winter storm making vehicular travel difficult in the Long Pines. Unseasonably cold temperatures prevailed during that period (Appendix Table 1).

Traffic in the Long Pines during the first week of the 1978 deer season was much higher than that observed during the same period of 1976 and 1977 (Figure 24). Assuming that the proportion of all traffic was consistent at the 2 locations during fall of all years, greatest traffic use occurred during 1978 of the years 1976-78. 


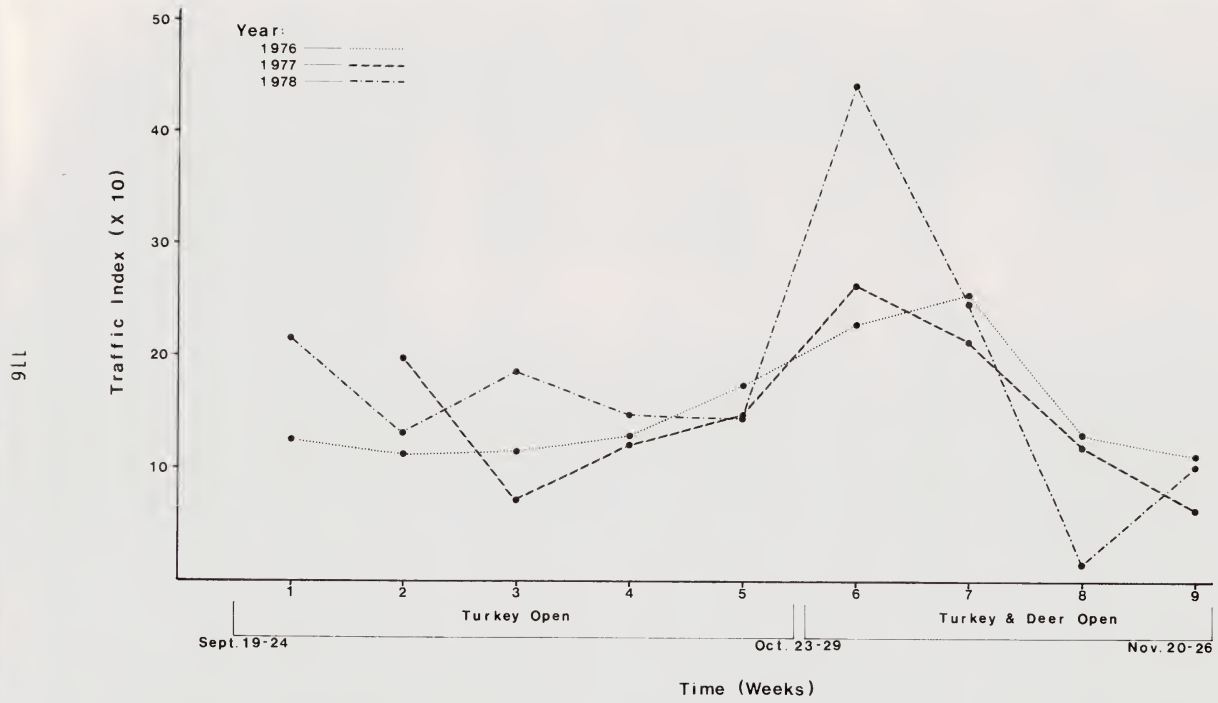

Figure 24. Weekly trends in traffic use in the Long Pines during the fall hunting seasons from $1976-78$. 
Table 34. Yearly trends in traffic indices during 3 periods of the hunting season from 1976-78.

\begin{tabular}{llll}
\hline Year & $\begin{array}{c}\text { Early Turkey } \\
\text { Season } \\
(4-5 \text { weeks })\end{array}$ & $\begin{array}{c}\text { First Ha lf } \\
\text { Deer Season } \\
(2 \text { weeks })\end{array}$ & $\begin{array}{c}\text { Second Half } \\
\text { Deer Season } \\
\text { (2 weeks) }\end{array}$ \\
\hline 1976 & $655(47)^{\mathrm{a}}$ & $483(35)$ & $243(18)$ \\
1977 & $538(45)$ & $478(40)$ & $184(15)$ \\
1978 & $828(51)$ & $689(42)$ & $118(7)$ \\
A11 Years & $(48)$ & $(39)$ & $(13)$ \\
\hline
\end{tabular}

a Traffic index (percent of yearly traffic).

For the combined years of 1976-78, 49 percent of all weekly traffic in the Long Pines occurred on weekends (Friday evening through Sunday evening). During the week following the opening of turkey and deer seasons, 58 and 50 percent of the respective weekly use occurred on those opening weekends. Although weekend traffic indices included the entire 48-hour period, the turkey season opened at noon on a Sunday in 1976 and on Saturday at noon during 1977 and 1978. The deer season opened one half hour before sunrise on a Sunday during all years. Traffic data indicated comparatively heavy hunter use near season openings (Figure 24) and particularly during opening weekends. Traffic data indicated periods of comparatively heavy use, whereas results from questionnaires indicated when the greatest number of individuals hunted.

\section{Harvest and Hunting Pressure}

Regulations for hunting Merriam's turkey allowed taking one turkey of either sex per license holder per fall hunting season. Deer license fees were increased from 1975 to 1976. Bag 1 imits were reduced from 2 deer in many hunting districts in 1975 to one deer (an antlered mule deer or a white-tailed deer of either sex) in a 11 hunting districts in 1976 (Swenson 1978b). During 1979 antlerless mule deer could also be taken on a " $A$ " tag but only during the final week of the season. " $B$ " tag permits were issued for white-tailed deer in some hunting districts during 1979 allowing permit holders a second deer. The Long Pines was included in one of those special permit areas.

Turkeys

From 1971-78 an average of 33 percent of the turkey hunters hunting in Region 7 hunted in Carter County accounting for 37 percent of the regional turkey harvest during that period (Knapp 1979). Numbers of 
hunters in Carter County and throughout Region 7 increased steadily from 1971 to 1975, declining a little in 1976 and 1977, but increased to the highest level recorded during the 8-year period in 1978. During the same period the highest levels of harvest and hunter success in Carter County occurred in 1978 which was attributed to good vegetative growth resulting from an abundance of rainfall during the growing season (Knapp 1979).

Estimated annual harvest of turkeys in the Lonq Pines from 1976-78 was only 10 percent of that reported for all of Carter County (Table 35). The highest level of harvest during the study was observed during 1979 . Data for all of Carter County are not yet available for comparison from 1979. Numbers of turkey hunters and levels of harvest and success in the Long Pines were undoubtedly underestimated for 1977 since the rate of response among parties contacted during the early turkey season that year was disproportionately low: 13 percent during the early turkey season and 46 percent throughout the deer season. During all years combined, 78 percent of the turkeys harvested were taken prior to the opening of the deer season which was also determined from the questionnaire.

Table 35. Fall turkey harvest for the Long Pines from 1976-79 and for a11 of Carter County from 1975-78 as determined from questionnaires.

\begin{tabular}{cccccccc}
\hline & \multicolumn{3}{c}{ Long Pines a } & & \multicolumn{3}{c}{ Carter County b } \\
\cline { 2 - 3 } Year & $\begin{array}{l}\text { Number } \\
\text { Hunters }\end{array}$ & $\begin{array}{c}\text { Birds } \\
\text { Harvested }\end{array}$ & $\begin{array}{c}\text { Percent } \\
\text { Success }\end{array}$ & $\begin{array}{l}\text { Number } \\
\text { Hunters }\end{array}$ & $\begin{array}{c}\text { Birds } \\
\text { Harvested }\end{array}$ & $\begin{array}{c}\text { Percent } \\
\text { Success }\end{array}$ \\
\hline 1975 & - & - & - & & 818 & 298 & 36 \\
1976 & 196 & 36 & 18 & & 526 & 214 & 41 \\
1977 & 104 & 19 & 19 & 623 & 276 & 44 \\
1978 & 182 & 52 & 29 & 1,035 & 584 & 56 \\
1979 & 147 & 63 & 42 & - & - & - \\
\hline
\end{tabular}

a Includes only the portion of the study area consisting of national forest (100 mi.2).

b From statewide hunter survey questionnaires as compiled by Knapp (1979).

Hunting pressure was expressed as hunter days per mile $\mathrm{e}^{2}$, whereas a hunter day is one hunter afield for one day. Hunting pressure for turkeys in the Long Pines averaged 3.8 hunter days per mile 2 per year from 1976-79 (Table 36). With the exception of 1977 when the number of 
hunters and level of harvest were underestimated, hunter days per mile $\mathrm{e}^{2}$ and days of effort per turkey harvested varied inversely with levels of harvest and hunter success. A statewide management objective for 1980 (Montana Department Fish and Game 1978) was 8 days of effort per turkey harvested which was surpassed in the Long Pines during both 1978 and 1979 (Table 36). In spite of the fact that only as much as 10 percent of the annual harvest of turkeys in Carter County comes from the Long Pines, it is noteworthy to mention that turkey harvest throughout the county either directly or indirectly resulted from the population established in the Long Pines in 1955.

Table 36. Hunting pressure and effort expended per animal harvested for deer and turkeys in the Long Pines from 1976-79.

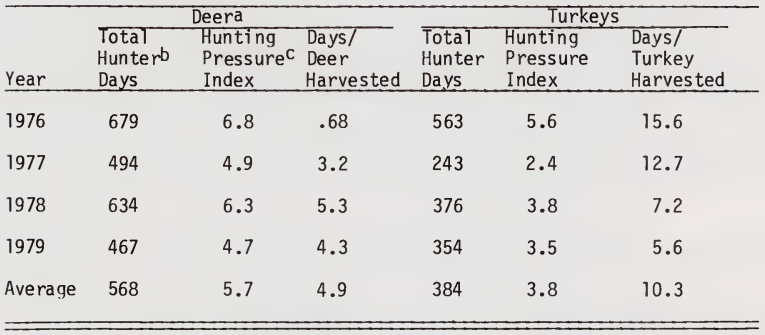

a Includes both mule and white-tailed deer.

b One hunter hunting one day constitutes one hunter day.

c Total hunter days divided by the number of square miles in the Long Pines unit of the Custer National Forest (100).

Deer

Eustace and Swens on (1977) reported a steady increase in the number of deer hunters in Region 7 from 1971 to 1975 which was accompanied by a steady decline in hunter success. Swens on (1978b) attributed el imination of the " $B$ " tag and initiation of buck-only mule deer hunting to a decline of 68 percent in hunter numbers which was comparatively greater among nonresidents. An increase in both resident and nonresident big game license fees from 1975 to 1976 may also have contributed to the decline in hunter numbers. A decline in hunter numbers was also observed 
in 1967 a year when big game license fees increased. A statutory statewide limit of 17,000 nonresident big game licenses was imposed during 1976 , but only 10,687 were sold. During 1975, 21,980 nonresident combination biq game hunting licenses were sold statewide.

The number of deer hunters declined by 78 percent from 1975 to 1976 in deer hunting district 781 (Table 37). A similar decline probably occurred in the number of deer hunters using the Long Pines. From 1976-78 estimated numbers of hunters in the Long Pines accounted for 22 percent of the reported number of deer hunters in hunting district 781 (Table 37). The Long Pines accounted for approximately 7 percent of the land area in the hunting district suggesting that hunter density was comparatively higher in the Long Pines than throughout the hunting district. This may be partially explained on the basis of differential accessibility of national forest and private lands. Trends in levels of harvest and hunter success in the Long Pines generally paralleled those reported for hunting district 781 (Table 37). The decline in harvest of white-tailed deer from 1977 to 1978 and 1979 was attributed to a population decline resulting from high mortality during the winters of 1977-78 and 1978-79 and from an epizootic of hemorrhagic disease during sumer 1978. An increase in the harvest of mule deer from 1977 to 1978 was attributed to a slight population increase for that species between those years.

Table 37. Deer harvest for the Long Pines from 1976-79 and for hunting district 781 from 1975-78 as determined from questionnaires.

\begin{tabular}{|c|c|c|c|c|c|c|c|c|}
\hline \multirow[b]{2}{*}{ Year } & \multicolumn{4}{|c|}{ Long Pinesa } & \multicolumn{4}{|c|}{ Hunting District $781^{\mathrm{b}}$} \\
\hline & $\begin{array}{l}\text { Number } \\
\text { Hunters }\end{array}$ & $\begin{array}{r}\mathrm{Ha} \\
\mathrm{MD} \\
\end{array}$ & $\begin{array}{l}\text { est } \\
\text { WT }\end{array}$ & $\begin{array}{l}\text { Percent } \\
\text { Success }\end{array}$ & $\begin{array}{l}\text { Number } \\
\text { Hunters }\end{array}$ & $\begin{array}{c}\mathrm{Har} \\
\mathrm{MD} \\
\end{array}$ & $\begin{array}{l}\text { est } \\
\text { WT }\end{array}$ & $\begin{array}{l}\text { Percent } \\
\text { Success }\end{array}$ \\
\hline 1975 & - & - & - & - & 4,302 & 1,497 & 1,497 & 69 \\
\hline 1976 & 241 & 10 & 90 & 41 & 958 & 227 & 341 & 59 \\
\hline 1977 & 210 & 32 & 123 & 74 & 919 & 301 & 367 & 73 \\
\hline 1978 & 191 & 47 & 73 & 63 & 1,088 & 322 & 310 & 58 \\
\hline $1979 \mathrm{C}$ & $166^{\mathrm{C}}$ & 25 & 83 & 65 & - & - & - & - \\
\hline
\end{tabular}

a Includes only the portion of the study area consisting of national forest $\left(100 \mathrm{mi}^{2}\right)$.

b Derived from statewide hunter survey questionnaires as compiled by Eustace and Swenson (1977), Swenson (1978b) and Swenson and Knapp (1979).

c Includes holders of special "B Tag" either-sex whitetail permits during 1979. 
Hunting pressure and days of effort per deer harvested are summarized in Table 36. Swens on (1978b) and Swenson and Knapp (1979) reported a harvest of (both species combined) $0.4,0.5$ and 0.4 deer per mi $1 e^{2}$ for hunting district 781 in 1976, 1977 and 1978, respectively, and 0.3 deer per mile2 throughout Region 7 during a 113 years. The estimated number of deer harvested per mi le 2 in the Long Pines from 1976-79 was 1.0, 1.5, 1.2 and 1.1 , respectively. The number of hunters per mi $1 e^{2}$ throughout Region 7 was 0.5 from 1976-78, while that in hunting district 781 was $0.7,0.6$ and 0.7 during the respective years (Swenson 1978b, Swenson and Knapp 1979). The estimated number of hunters per mile2 in the Long Pines from 1976-79 was $2.4,2.1,1.9$ and 1.7 , respectively. Days of effort per deer harvested in the Long Pines for the 4 years averaged 4.9 days (Table 36). Harvest goals for deer in Region 7 for 1980 (Montana Dept. Fish and Game 1978) are 80 percent hunter success and 5 days of effort per deer harvested.

\section{Unique Recreational Values}

The comparatively high levels of use by deer hunters and harvest of deer in the Long Pines accompanied by comparatively high rates of hunter success exemplified the high potential offered by the area for deer hunting. Since white-tailed deer accounted for 76 percent of the deer harvest in the Long Pines from 1976-79, levels of harvest and hunter success were undoubtedly attributable to high population densities of white-tailed deer on the national forest. Holsworth (1973) reported a direct relationship between density of deer and levels of harvest and hunter efficiency. White-tailed deer accounted for 53, 45 and 41 percent of annual harvest throughout Region 7 in 1976, 1977 and 1978, respectively (Swenson 1978b, Swenson and Knapp 1979).

The Long Pines have received widespread attention as a turkey hunting area since 1958. In addition, the area has also served as a source of wild stock to establish populations of turkeys in other parts of Montana (Greene and ElTis 1971).

The aes thetic beauty of the Long Pines was cited as a major factor attracting hunters to the Long Pines (Table 38). This was especially true among residents responding to the questionnaire in 1978-79. Non-resident hunters also cited the abundance of game, the proximity to home and the quality of the experience as factors attracting them to the Long Pines. of 11 parties citing reasons for hunting in the Long Pines other than those offered in the questionnaire, 5 mentioned access, and that they did not have to ask permission to hunt, as the most important reason. of those 5 , 4 were parties of resident hunters. It may have been cited more often as a major reason for hunting in the area had it been offered among the choices. However, it would be difficult to deny that the Long Pines offer a unique aesthetic quality to the landscape of southeastern Montana.

Forty-nine percent of al1 responding parties in 1978-79 indicated that mineral development in the Long Pines with its associated human 
activity, regardless of any direct impact on the wildlife resource, would affect their decision to hunt there in the future, while only 20 percent indicated it would not (Table 39). A larger proportion of residents indicated development would affect their decision to hunt, while a larger proportion of nonresidents were undecided.

Table 38. Reasons offered by respondents to the questionnaire as to why they chose to hunt in the Long Pines (1978-79).

\begin{tabular}{lccc}
\hline $\begin{array}{l}\text { Question: What do you feel is the single most important factor attracting } \\
\text { you to the Long Pines to hunt? }\end{array}$ & $\begin{array}{c}\text { Residents } \\
(41) \mathrm{c}\end{array}$ & $\begin{array}{c}\text { Total } \\
\text { (18) }\end{array}$ \\
\hline $\begin{array}{l}\text { Choices offered } \\
\text { Proximity to home }\end{array}$ & $7 d$ & 17 & 10 \\
Aesthetics & 39 & 22 & 34 \\
Abundance of game & 5 & 22 & 10 \\
Quality of experience & 10 & 17 & 12 \\
Othera & 24 & 6 & 19 \\
No response & 15 & 17 & 15 \\
\hline
\end{tabular}

a Reasons related to hunter access were offered by 5 of 11 parties responding in this category.

b Parties that had answered this question in 1978 were asked to abstain during 1979.

C Number of parties responding.

d Percent of responding parties. 
Table 39. The potential effect of mineral development on attitudes of hunters towards hunting in the Long Pines (1978-79).

\begin{tabular}{lccc}
\hline Nuestion: & $\begin{array}{l}\text { Would mineral development with its associated human activity, } \\
\text { regardless of any impact on the wild ife resource itself, } \\
\text { affect your decision to hunt in the Long Pines in the future? }\end{array}$ \\
\hline $\begin{array}{l}\text { Residents } \\
(41)^{\mathrm{b}}\end{array}$ & $\begin{array}{c}\text { Nonresidents } \\
(18)\end{array}$ & $\begin{array}{c}\text { Total } \\
\text { Choices offered }\end{array}$ \\
\hline Yes & $51^{\mathrm{C}}$ & 44 & 49 \\
No & 20 & 17 & 19 \\
Undecided & 17 & 28 & 20 \\
No response & 12 & 11 & 12
\end{tabular}

a Parties answering this question in 1978 were asked to abstain in 1979.

b Number of parties in sample.

c Percent of sample. 
PART IV - IMPLICATIONS OF URANIUM DEVELOPMENT

\section{Exploration Activity in the Long Pines}

Mobil's exploration drilling activity was concentrated in the southern two-thirds of the Long Pines unit of the Sioux District (Allen 1979). The area included the densely timbered upland portions of the Long Pines primarily the ponderosa pine-mesic shrub habitat group.

The primary target of Mobil's drilling was Fox Hills Sands tone. The Hell Creek Formation was a secondary target although all holes were drilled into the Pierre Shale to be certain the entire Fox Hills Formation had been penetrated (Allen 1979). Truck-mounted rigs were used to drill exploratory holes to depths of 350 to 1300 feet ( 100 to $400 \mathrm{~m}$ ) (Stellingwerf 1975). Approximately 8,000 gallons of water were used at each hole drilled of which approximately 2,000 were recoverable for use at the next hole. It appeared that exploratory holes penetrated aquifers in the Fort Union Formation as well as the lower Hell CreekFox Hills aquifer. It was anticipated that a constant circulation of water and bentonite gel would seal each hole preventing cross contamination of aquifers (Stellingwerf 1975). After holes were radiologically logged they were plugged following guidelines of the State of Montana and the U.S. Forest Service.

From 1973-74 trenches, which affected approximately 0.1 acre (0.04 ha), were dug with a hackhoe for drilling mud, whereas portable pits were used from 1975-77. Following drilling topsoil was replaced at each drill site (1973-74) which was then disked, seeded, fertilized and mulched (Stellingwerf 1975). Seed mixtures included little bluestem, western wheatgrass, green needlegrass, blue grama, Kentucky bluegrass and yellow sweetclover (Nordberg 1980). Crested wheatgrass (Agropyron desertorum) and alkali sacaton (Sporobolis airoides) were also applied on high sodium soils. Fertilizer was applied at a rate of $2001 \mathrm{bs} / \mathrm{acre}(224 \mathrm{~kg} / \mathrm{ha})$. A mud disposal pit on the north side of Plum Creek was back-filled and revegetated in a similar manner. Revegetated areas were fenced to preclude use by livestock for a period of 2 to 3 years. A subjective examination of several of those sites indicated that vegetative cover had been established, and the sites were generally indistinguishable from surrounding

\section{Mining Technique}

Solution, in-situ or leach mining involves drilling into a body of ore, injecting an extractive fluid to dissolve the mineral, recovering the mineral and separating it from the fluid and recycling the fluid (Shock and Conley 1974). Uranium ores are generally suitable to leaching methods since the host rock is usually a permeable sandstone favoring percolation of leach solutions, and uranium generally lies below a water table which is necessary for containment of leach solutions (Carnahan 1975). 
Wyoming Mineral Corporation (1976) described a solution mining process that would perhaps be suitable for recovery of uranium from the Long Pines in the event that such reserves are ever developed there. Such a system would reverse the rollfront deposition process but at an accelerated rate. When an ore body has been identified, several wells 4-6 inches $(10-15 \mathrm{~cm})$ in diameter, which are presumably sealed to preclude contamination of other aquifers, are drilled into the ore body. The number and arrangement of these clusters of wells are determined by the size and arrangement of the ore body, flow rate of the solution or ground water through the aquifer and the chemical composition of the ore body (Allen 1979). The type of solution used also depends on the chemical properties of the ore body. About half the wells are used for injecting and the remainder are used for recovery (Wyoming Mineral Corp. 1976). A series of monitor wells are placed around the leach field that are intended to indicate any migration of leaching solution above and outward from the ore body. Upon recovering the solution with the dissolved mineral, it is processed by an ion exchange and precipitation system. The uranium-laden resin from the ion exchange may be processed at the recovery site, or it may be transferred to be concentrated at a mill in another location (Allen 1979). The size of a well field and plant in Texas occupied an area less than 20 acres (8 ha) (Wyoming Mineral Corp. 1976).

\section{Environmental Considerations}

\section{Advantages}

In-situ mining enables development of bodies of ore under lands where other methods may not be practical or feasible (for whatever reasons), requires a comparatively small disturbance of surface resources for a mining and milling plant, and since uranium is recovered in a solution, some of the processes of milling are eliminated (Allen 1979). Most importantly the mass ive disturbance and movement of soils and bedrock is eliminated by an in-situ process. Conditions necessary for recovering uranium by an in-situ process have been discussed by Allen (1979) and others.

\section{Potential Problems}

Laws and regulations regarding mining and milling of uranium are quite complex and involve jurisdiction between individual states and the federal government (Friedman 1978). Mining and milling are basically regulated by the Nuclear Regulatory Commission (NRC) through the Atomic Energy Act of 1954. It is unclear whether regulations requiring an environmental statement regarding milling under the Code of Federal Regulations (CFR) would apply to in-situ mining. In addition individual states do not have authority to deal with environmental impacts of radioactive material resulting from recovery of uranium unless delegated by agreement with the NRC. 
Other legal problems arise from the fact that federal agencies have extremely limited authority regarding locatable minerals which are regulated by the U.S. Mining Law of 1872. The Department of the Interior drafted regulations dealing with disturbances in connection with activities concerning locatable minerals under authority of the Federal Land Policy Management Act of 1976 (Friedman 1978). It is debatable whether the proposed regulations are within the scope of this Act. The Forest Service Manual emphasizes the prospector and miner have a legal right to search for and take valuable deposits of locatable minerals and secure title to national forest lands involving affected surface resources without permission of the Forest Service. The Forest Service (1976b) discussed environmental considerations for deep mineral recovery in their Final Environmental Statement for the Sioux District. A notice of intent and plan of operations were required of prospecting parties by the Forest Service. With prospecting, mining and milling of uranium under Federal jurisdiction on the national forest, it is unclear what jurisdiction Montana's environmental statutes would have in protecting wildlife habitat on the public domain, which includes national forest lands where uranium is a locatable mineral.

Shock and Conley (1974) cited failure to contain the solution in the ore body, thus contaminating ground water, as a potential environmental problem inherent in the in-situ mining process. Perry (1935) reported that Fox Hills Sandstone is the most important artesian horizon in southeastern Montana. The Fox Hill-lower Hell Creek aquifer is the most extensively used aquifer in the Powder River area of southeastern Montana (Miller 1979). The quality of this ground water, which generally flows northwest east of the Powder River, is presently considered acceptable for most uses. The ground water in the Fort Union Formation is shallower and flow is influenced mainly by surface topography: i.e., discharge occurs as seeps and springs throughout the Long Pines. Due to the relatively slow rate of flow of most ground water, contamination may not be detected in neighboring areas for years. When it is, the damage may not be rectified merely by stopping the pollution (Terral 1979). Although the mining industry has made assurrances that such contamination is unlikely, due to monitoring and mining procedures, contamination of ground water with radioactive material remains a threat to local and regional sources of underground water. During drilling there is also the possibility of cross contamination. Such contamination of ground water in the Fort Union Formation from exploration and mining would affect water used directly or indirectly by wildlife and by recreational users of the Long Pines.

Surface disturbance, although minimal compared to other mining techniques, would require clearing vegetation from injection and recovery well sites including surge and holding tanks, the ion exchange equipment in addition to roads and equipment areas (Alien 1979). Siting of these facilities is of paramount importance when considering habitat protection. In addition to surface disturbance, increased human activity in the area associated with development offers potential adverse effects regarding nesting raptors. Although birds of prey continue to occupy areas subjected to disturbance, success of nesting usually decreases (Swenson 1979b). 
The potential adverse effects of emissions of radon gas and associated alpha and gamma radiation at these facilities is not well documented (Allen 1979) or perhaps not well publicized by the mining industry. The biological hazards of such contamination are discussed by Terral (1979). It has been documented that higher than normal levels of radiation decrease fertility and increase mortality of songbirds (Willard 1963, Wanger and Marples 1966, Buech 1976). 
PART $V$ - CONCLUSIONS AND RECOMMENDATIONS

Unique Resource Values

$$
\text { Wildifie }
$$

Game

White-tailed deer appeared more dependent on the upland ponderosa pine community than did mule deer and, with the exception of turkeys, small game. Their distribution during winter was confined almost exclusively to that comunity in the study area, particularly the ponderosa pine-mesic shrub sites. Such sites provided forage and thermal cover, although forage availability was limited by deep snow during comparatively harsh winters. Mule deer also selected pine habitat during winter, but this use was confined primarily to ponderosa pine-xeric grassland/shrub sites. As opposed to white-tailed deer, mule deer continued to use prairie and other nontimbered sites during winter.

In southeastern Montana white-tailed deer are associated primarily with riparian and/or agricultural habitat along the major streams and in the ponderosa pine uplands of Carter County. Dispersal of whitetails from the Long Pines during spring, summer and fall was associated with seasonal use of riparian and agricultural habitat along the major water courses in the area and with neighboring ponderosa pine uplands. Several individually marked animals summered either on the Little Missouri River or the West Short Pines in Harding County, South Dakota. Movement to the Sheep Mountains, which lie just south of the Long Pines, was also documented. It is likely that whitetails also move to and from Boxelder Creek to the west of the Long Pines, although such movement was not documented during this study.

Several factors are likely respons ible for the comparatively high population density of white-tailed deer in the Long Pines. The fundamental component of yearlong whitetail habitat was the ponderosa pine-mesic shrub habitat group. Although upland portions of the Long Pines normally receive in excess of 15 inches $(380 \mathrm{~mm})$ of precipitation annually, retention of moisture and subirrigation are undoubtedly essential for maintenance of these sites which are predominant throughout the southern portion of the Long Pines. Geologically this portion is capped by sandstones of the Arikaree Formation which give way to coarse, well-drained soils minimizing loss of water through surface runoff. It provides a rather large recharge area for aquifers in the Fort Union Formation. Fort Union shale serves to impede further direct downward movement of water which is discharged through seepage and developed springs in many of the drainages in the southern two-thirds of the Long Pines. These conditions support comparatively dense stands of pine, with the exception of steep southerly exposures and some ridgetops, and an understory of shrubs dominated by snowberry, Oregon grape and/or chokecherry. A11 3 shrubs are major browse species used by white-tailed deer. Assuming that distribution of white-tailed deer was associated with the more mesic sites in the study area, it is noteworthy to mention that the largest concentrations of whitetails occurred in the southern portion of the study area primarily in the Speelman, Plum and Tie Creek drainages. 
The affinity of white-tailed deer to upland conifer habitat during winter is influenced, at least partially, by the general physiography of the region east of the Powder River. The few pine dominated uplands provide the only substantial topographical relief. For example, the elevational relief from the southeast corner of the Long Pines to the floodplain of the Little Missouri River, a distance of approximately $3.5 \mathrm{miles}(5.6 \mathrm{~km})$ is a gradual 200 feet $(61 \mathrm{~m})$. Considering the behavioral response of white-tailed deer to harsh winter climates, the relatively shallow drainages, such as the Little Missouri River and Boxelder Creek, with a deciduous tree overstory do not lend themselves to reducing wind chill as does the dense canopy of pine and broken topography of the Long Pines. During periods of extremely cold weather, air temperatures at higher elevations in the Long Pines were undoubtedly a few degrees warmer than on the surrounding plains. This is not to infer that white-tailed deer did not winter along the above mentioned drainages but rather to explain the dispersal of whitetails from the Long Pines during spring and summer and their concentration there during winter.

Complexes of riparian and agricultural habitat or grasslands in and near the national forest were important habitat for white-tailed deer and served to complement use of the ponderosa pine habitat by at least a segment of the population. However, such habitat is most important during spring, summer and fall.

Establishment of turkeys in the Long Pines represented one of the most successful introductions of this game bird in Montana. Jonas (1966) attributed the success of the introduction to proper interspersion of pine with nonforested types, food, water and rugged terrain. Pine and grassland communities were important habitat for turkeys during spring, summer, and fall, but the riparian tree/shrub sites received heavy use during winter. The abundance and distribution of water may have benefited the proliferation of turkeys in the Long Pines.

Nongame

Riparian habitat supported the greatest diversity and density of breeding nongame birds. It likely supported a comparatively wide variety of nongame mammals as well. Both groups are important prey for avian and mammalian predators. Ponderosa pine communties were also important habitat for song birds, especially the ponderosa pine-mesic shrub sites. These sites also provide nesting habitat for Cooper's and sharp-shinned hawks which DuBois (1980) reported may be comparatively more common in the Long Pines than in other areas of southeastern Montana. Merlins were also quite common in the Long Pines study area. These 3 species of raptors prey almost exclusively on songbirds and their relative abundance in the area may be related to the abundance of prey species.

Although cliff nesting species, such as golden eagles and prairie falcons, undoubtedly breed throughout southeastern Montana, cliffs suitable for aeries accounted for only a small fraction of the study area. Availability of these sites may limit the number of pairs that nest in the area. 


\section{Recreation}

The large block of public land making up the Long Pines unit of the Custer National Forest, combined with well defined physical and legal access by recreational users, is quite unique to eastern Montana. Many tracts of public land in eastern Montana, primarily those administered by the BLM, lack this access, and their use by recreationists is solely at the mercy of the private landowner who controls access to them. The Long Pines offer, both qualitatively and quantitatively, a high potential for wildlife oriented recreation.

Nearly all hunters using the Long Pines during fall were from outside the immediate vicinity of the Long Pines. It is conveniently located logistically for nonresident hunters from the Midwest who come to Montana to hunt turkeys and/or deer. Many nonresidents stop there to hunt deer on their way home from hunting elk in western Montana. The Long Pines are also a popular area with hunters from Fallon, Custer, Dawson and Richland counties where the larger urban communities in southeastern Montana are located. Turkey hunting in the Long Pines appeared more popular among resident hunters than nonresidents, whereas deer hunting was popular among both groups. The Long Pines are one of the few tracts of federal land in eastern Montana where white-tailed deer are the most abundant species of big game. They accounted for 76 percent of the deer harvested in the Long Pines during the period of study.

In light of the remoteness of the Long Pines from human population centers, they received comparatively greater hunter use than southeastern Montana as a whole or than deer hunting district 781 . Federal ownership of the Long Pines and the fact that hunters did not have to ask permission tc hunt may have at least partially accounted for this since only 29 percent of all of Carter County is in federal ownership. However, the aesthetics and qual ity of previous hunting experiences in the area were also important factors attracting hunters to the Long Pines. This contention is supported by the fact that mineral development would discourage a large proportion of hunters from hunting in the area. The level of harvest was also higher in the Long Pines than for Region 7 as a whole or deer hunting district 781 . Levels of harvest, hunter success and days of effort per deer harvested appeared related to deer density and were assumed to be independent of hunter density, at least at levels of hunter density during the period of 1976-79.

\section{Recommendations}

Since mining of uranium in the Long Pines is not likely to occur in the immediate future, the following reconmendations are general in nature and emphasize wildlife habitat and recreation values that merit protection in the event the area should be mined in the future.

1. The U.S. Mining Law of 1872 was obviously written for the benefit of the mining industry at a time when preservation and enhancement of other resource values were not of any particular concern to the public. Withdrawal from mineral location of several sites in the Long Pines, including the 2 campgrounds, an area around Capitol Rock as a national 
historic landmark and a couple of grave sites, demonstrated some administrative authority in reference to U.S. mining laws. However, preservation of wildlife and recreation values in the Long Pines will require additional safeguards. It would be desirable to reclassify uranium to a leaseable from a locatable mineral for 2 reasons. First, it would eliminate the industry's right to acquire surface ownership to what are presently national forest lands and allow federal and state agencies some authority in planning the operation to minimize or eliminate adverse effects on wildlife. Secondly, reclassifying uranium would guarantee envi ronmental considerations not provided by U.S. mining laws and might actually give some authority to the Forest Service Environmental Statement regarding uranium recovery. This would also facilitate preparation of environmental statements regarding the specific development.

2. Special effort should be made to discourage placement of facilities in ponderosa pine or riparian habitats. Protection of these sites is covered in the environmental statement for the Sioux District (U.S. Forest Service $1976 \mathrm{~b})$ assuming the document has authority over uranium recovery. Ponderosa pine-mesic shrub sites constitute critical habitat for white-tailed deer and provide nesting habitat for Cooper's and sharp-shinned hawks and a variety of song birds.

Riparian habitat is important to a variety of wildlife including whitetailed and mule deer, sharp-tailed grouse, Merriam's turkeys and a host of song bird species. Such habitat values should preclude any additional road construction or placement of mining facilities in this type.

3. The potential for contamination of ground water through cross contamination should serve as criteria for siting of mining facilities. Facilities should be sited to avoid drilling through the Fort Union Formation.

4. Increases in human population associated with mineral development should be absorbed in nearby communities such as Camp Crook, South Dakota or Ekalaka, Montana rather than within or adjacent to the national forest. Planning for the human impact is necessary to preserve the aesthetic, wildlife and recreational values of the Long Pines.

5. The Forest Service should be encouraged to incorporate the ecological data obtained during this study, particularly that regarding deer and nongame birds when the need arises to update the environmental statement for the Sioux District. Lists of indicator wildlife species associated with the ponderosa pine and hardwood draw ecosystems (U.S. Forest Service 1976a) should be updated since the information is presumably incorporated into management decisions regarding various resource activities. White-tailed deer should be included among the indicator species in the ponderosa pine bench ecosystem rather than mule deer since mule deer rarely occur on those sites. Both species of deer should be listed as indicator species for the ponderosa pine slope, ponderosa pine steep and the hardwood draw ecosystems. The list of diagnostic species of song birds could most likely be increased for several ecosystems. 


\section{LITERATURE CITED}

Allen, E.0. 1968. Range use, foods and productivity of white-tailed deer in Montana. J. Wild l. Manage. 32(1):130-141.

1971. White-tailed deer. pp. 69-79 in Mussehl and Howell, eds., Game Management in Montana. Montana Dept. Fish and Game. 238 pp.

Allen, G.T. 1979. An assessment of potential conflicts between nesting raptors and human activities in the Long Pines area of southeastern Montana with special emphasis on uranium development. Unpubl. M.S. Thesis, Washington St. Univ., Pullman. 109 pp.

American Ornithologists' Union. 1957. Checklist of North American birds. 5th ed., Ithaca, New York. 691 pp.

- 1973. 30th supplement to the American

Ornithologists' Union checkl ist of North American birds. Auk 90(2): 411-419.

- 1976. 33rd supplement to the American

Ornithologists ${ }^{\prime}$ Union checkl ist of North American birds. Auk 93(4): 875-879.

Arno, S.F. 1979. Forest regions of Montana. U.S. Forest Service, USDA, Res. Pap. INT-218. $39 \mathrm{pp}$.

Bailev, J.A. 1967. Sampling deer browse for crude protein. J. Wild1. Manage. $31(3): 437-442$.

Barron, J.C. and W.F. Harwel1. 1973. Fertilization rates of south Texas Deer. J. Mild l. Manage. $37(2): 179-182$.

Bauer, C.M. 1924. The Ekalaka lignite field, southeastern Montana. U.S. Geol. Sur. Bul1. No. 751. pp. 231-267.

Booth, W.E. 1950. Flora of Montana, Part I - conifer and monocots. Res. Found., Montana St. Col1., Bozeman. 232 pp.

, and J.C. Wright. 1959. Flora of Montana, Part II - dicotyledons, Montana St. Col1., Bozeman. 305 pp.

Brown, R.W. 1971. Distribution of plant communities in southeastern Montana badlands, Am. Midl. Nat. 85(2):458-477.

Buech, R. 1976. Avian nesting success under gama radiation exposure. Auk 93(3):627-628.

Ca11, M.W. 1978. Nesting habitats and surveying techniques for common western raptors. Bur. Land Manage., USDI, Tech. Hote TN-316. 115 pp. 
Cameron, E.S. 1907. The birds of Custer and Dawson counties, Montana. Auk $24: 241-270,389-406$.

Campbell, R.B. 1970. Pronghorn, sheep and cattle relationships in Carter County, Montana. Unpubl. M.S. Thesis, Montana St. Univ., Bozeman. 87 pp.

Carlsen, J.C. and R.E. Farmes. 1957. Movements of white-tailed deer tagged in Minnesota. J. Wild1. Manage. 21 (4):397-401.

Carnahan, T.G. 1975. In-situ leaching of uranium. Pres. Soln. Mining Short Course, Mackay Sch. Mines, Univ. Nevada, Reno. 18 pp.

Carter County Conservation District. 1976. Long range program, Soil Cons. Ser., USDA. 72 pp.

Caughley, G. 1977. Analysis of vertebrate populations. John Wiley and Sons. $234 \mathrm{pp}$.

Cheatum, E.L. 1949. The use of corpora lutea for determining ovulation incidence and variations in the fertility of white-tailed deer.

Cornell Vet. 39(3):282-291.

and F.H. Morton. 1946. Breeding season of white-tailed deer in New York. J. Wildl. Manage. 10(3):249-263.

Dubenmire, R. 1959. A canopy coverage method of vegetational analysis. i.. Sci. 33(1);43-64.

- 1968. Plant communities - a textbook of plant synecology, Harper \& Row, New York. 300 pp.

Denson, N.M. and J.R. Gill. 1965. Uranium-bearing lignite and carbonaceous shale in the southwestern part of the Williston Basin - a regional

study. U.S. Geol. Sur. Prof. Pap. No. 463.

Dix, R.L. 1958. Some slope-plant relationships in the grasslands of the Little Missouri badlands of North Dakota. J. Range Manage. 11:88-92.

Downing, R.L. and B.S. McGinnes. 1975. Movement patterns of white-tailed deer in a Virginia enclosure. Proc. 29th Conf. S.E. Assoc. Game and Fish Comm. pp 454-459.

, E.D. Michael and R.J. Poux. 1977. Accuracy of sex and age ratio counts of white-tailed deer. J. Wildl. Manage. 41(4):709-714.

Drolet, C.A. 1976. Distribution and movements of white-tailed deer in southern New Brunswick in relation to environmental factors. Canadian Field Nat. 90(2):123-136. 
DuBois, K.L. 1979. An inventory of the avifauna in the Long Pines of southeastern Montana. Unpubl. M.S. Thesis, Montana St. Univ., Bozeman. 113 pp.

- 1980. Fish and Wildlife Biologist, Montana Dept. Fish, WiTdlife, and Parks, Ashland. Personal communication.

Dusek, G.L. 1977. In-situ uranium mining, Long Pines, Montana. Prog. Rep., Montana Dept. Fish and Game. 54 pp.

. 1978. Bull Mountains coal field study. Final Rep., Montana Dept. Fish and Game. 120 pp.

- 1979. Population dynamics of white-tailed deer in southeastern Montana with reference to mortality. Prairie Wildl. Hab. Conf., Brooks, Alberta. 12 pp.

Eustace, C.D. 1971. Mule deer food habits and browse use study. Final Rep., Montana Dept. Fish and Game, Proj. W-130-R-1 and 2, Job No. I-7.1. $25 \mathrm{pp}$.

and J.E Swenson. 1977. Biq game survey and inventory (Deer) Region 7 , including an analysis of deer harvest data, 1960-75. Montana Dept. Fish and Game, Proj. W-130-R-8, Job No. I-7. 39 pp.

Feldner, T. 1980. Graduate student, Vet. Res., Montana St. Univ., Bozeman. Personal Communication.

Fenneman, N.M. 1931. Physiography of western United States. McGrawHil1, New York. $534 \mathrm{pp}$.

Flath, D.L. 1979. Nongame species of special interest or concern. Montana Dept. Fish, Wildl. and Parks, Wildl. Div. 73 pp.

Freeman, J.S. 1971. Pronghorn range use and relation to livestock in southeastern Montana. Unpubl. M.S. Thesis, Montana St. Univ., Bozeman. $45 \mathrm{pp}$.

Friedman, F.B. 1978. Environmental problems relating to uranium mining and milling. Nat. Res. Lawyer $11(2): 277-302$.

Gilbert, F.F. 1966. Aging white-tailed deer by annuli in the cementum of the first incisor. J. Wild1. Manage. 30(1):200-202.

fireene, R. and R. El1is. 1971. Merriam's turkey. pp 167-173 in Musseh1 and Howell, eds., Game management in Montana. Montana Dept. Fish and Game. 238 pp.

Hamlin, K.L. 1979. Population ecology and habitat relationships of white-tailed deer on bottomlands of the Missouri River in Northcentral Montana. pp 167-174 in Montana deer studies. Prog. Rept., Montana Dept. Fish and Game, Proj. W-120-R-8. 
Harmoning, A.K. 1976. White-tailed deer dispersion and habitat utilization in central North Dakota. Unpub1. M.S. Thesis, North Dakota St. Univ., Fargo. 37 pp.

Hawkins, R.E. and W.D. Klimstra. 1970. A preliminary study of the social orqanization of white-tailed deer. J. Wildl. Manage. 34(2):407-419.

Herbert, J.T. 1977. An inventory of the bird populations within the Sarpy Creek drainage, southeastern Montana. Unpubl. M.S. Thesis, Montana St. Univ., Bozeman. $81 \mathrm{pp}$.

Hickey, J.J. and S.A. Mikol. 1979. Estimating breeding bird densities on coal lands in Montana and Wyoming. U.S. Fish and Wild1. Serv., WELUT79/03.

Hill, R.R. 1946. Palatability ratings of Black Hills plants for whitetailed deer. J. Wildl. Manage. 10(1):47-54.

Hoff, G.L., S.H. Richards and D.0. Trainer. 1973. Epizootic of hemorrhagic disease in North Dakota deer. J. Wild1. Manage. 37(3):331-335.

Hoffman, R.S. and D.L. Pattie. 1968. A guide to Montana mammals: identification, habitat, distribution and abundance. Univ. Montana Print Serv. 133 pp.

Holsworth, W.N. 1973. Hunting efficiency and white-tailed deer density. J. Wild T. Manage, 37(3):336-342.

Hudson, P. and L.G. Browman. 1959. Embryonic and fetal development of the mule deer. J. Wildl. Manage. 23(3):295-304.

Jarrard, L.D. 1957. Some occurrences of uranium and thorium in Montana. Montana Bur. Mines and Geol. Misc. Contrib. No. 15. 90 pp.

Johnson, J.R. and J.T. Nichols. 1970. Plants of South Dakota grasslands. Agr. Expt. Sta., South Dakota St. Univ., Brookings, $163 \mathrm{pp}$.

Jonas, R. 1966. Merriam's turkey in southeastern Montana. Montana Dept. of Fish and Game, Tech. But1 No. 3. $36 \mathrm{pp}$.

. 1968. Adverse weather affects Merriam's turkey reproduction in Montana. J. Wildl. Manage. 32(4):987-989.

Jones, J.K., Jr., R.P. Lampe, C.A. Spenrath and T.H. Kunz. 1973. Notes on the distribution and natura 1 history of bats in southeastern Montana. Occas. Pap. Mus. Texas Tech. Univ. 15:1-12.

Jordan, J.W. and P.A. Vohs, Jr. 1976. Natality of black-tailed deer in McDonald State Forest, Oregon. N.W. Sci. 50(2):108-113. 
Jorqensen, H.E. 1979. Vegetation of the Yellow Water Triangle, Montana. Montana Dept. Fish and Game, Wildl. Div. $57 \mathrm{pp}$.

Julander, O., W.L. Robinette and D.A. Jones. 1961. Relation of summer range condition to mule deer herd productivity. J. Wildl. Manage. 25(1):54-60.

Kammermeyer, K.E. and R.L. Marchington. 1976. Notes on dispersal of whitetailed deer. J. Mamm. 57(4):776-778.

and - 1977. Seasonal change in circadian activity of radio-monitored white-tailed deer. J. Wildl. Manage. $41(2): 315-317$.

Kamps, G.F. 1969. White-tailed and mule deer relationships in the Snowy Mountains of Montana. Unpub]. M.S. Thesis, Montana St. Univ., Bozeman. $59 \mathrm{pp}$.

Knapp, S.J. 1977. Birney-Decker wildlife study. Montana Dept. Fish and Game, Final Rep. 163 pp.

- 1979. Upland game bird surveys and inventory - Region 7.

Montana Dept. Fish and Game, Proj. W-130-R-10, Job II-7. 13 pp.

Koch, E. 1941. Big game in Montana from early historical records. J. Wildl. Manage. 5(4):357-370.

Lampe, R.P. J.K. Jones, Jr., R.S. Hoffman and E.C. Birney. 1974. The mamma ls of Carter County, Southeastern Montana. Occas. Pap. Mus. Nat. Hist., Univ. Kansas, Lawrence 25:1-39.

Larson, T.J., 0.J. Rongstad and F.W. Terbilcox, 1978. Movement and habitat use of white-tailed deer in southcentral Wisconsin. J. Wild. Manage.
$42(1): 113-117$.

Lonner, T.N. 1976. Long Tom Creek study. pp. 15-56 in Montana cooperative elk-logging study. Prog. Rep., Job II-B.

Low, W.A. and I.M. Cowan. 1963. Age determination of deer by annular structure of dental cementum. J. Wi ld1. Manage. 27(3):466-471.

Ligon, J.S. 1946. History and management of Merriam's turkey. New Mexico fame and Fish Comm. $84 \mathrm{pp}$.

MacArthur, R.H. and J.M. MacArthur. 1961. On bird species diversity. Ecol.
42:594-598.

Mackie, R.J. 1964. Montana deer weights. Montana Wildl., winter pp. 9-14. - 1970. Range ecology and relations of mule deer, elk and cattle in the Missouri River Breaks, Montana. Wildl. Mono. 20. $79 \mathrm{pp}$.

Martin, A.C., R.H. Gensch and C.P. Brown. 1946. Alternative methods in upland gamebird food analys is. J. Wildl. Manage. $10(1): 8-12$. 
Martin, N.S. 1980. Hild1. Mgr., Region 7, Montana Dept. Fish, Hildl. and Parks, Miles City. Personal communication.

Martin, P.R. 1977. Sarpy Basin wildlife ecology study. Prog. Rep. Montana Dept. Fish and Game. 74 pp.

Martinka, C.J. 1968. Habitat relationships of white-tailed and mule deer in northern Montana. J. Wild1. Manage. 32(3):558-565.

- 1970. Winter foods of white-tailed deer in Glacier National Park, Montana. Proc. W. Assoc. Game and Fish Comm. 6 pp.

Mathews, W.C. 1979. Wibaux-Beach wildlife baseline study - nongame species. Bur. Land Manage., USDI, Miles City, Montana. 93 pp.

Miller, W.R. 1979. Water resources of the central Powder River area of southeastern Montana. Montana Bur. Mines and Geo1., Bu11. No. 108. 65 pp.

Moen, A.N. 1968. Surface temperatures and radiant heat loss from whitetailed deer. J. Wildl. Manage. 32(2):338-344.

Montana Bureau of Mines and U.S. Geological Survey. 1978. Ground water of the Fort Union coal region, eastern Montana. Spec. Publ. 80. 47 pp.

Montana Department of Community Affairs. 1975. Profiles for Carter County. Div. Res. and Info. Sys.

Montana Department of Fish and Game. 1978. Design for tomorrow 1977-1990. $48 \mathrm{pp}$.

Morton, G.H. and E.L. Cheatum. 1946. Regional differences in breeding potential of white-tailed deer in New York. J. Wildl. Manage. 10(3): 242-248.

Mundinger, J.G. 1979. Population ecology and habitat relationships of whitetailed deer in coniferous forest habitat of northwestern Montana. pp. 5-65 in Montana deer studies, Prog. Rep., Montana Dept. Fish and Game. Proj. IV-120-R-10, Job. i.

Murie, 0.J. 1951. The elk of North America. The Stackpole Co., Harrisburg, Pennsylvania. 376 pp.

Nellis, C.H. 1968. Productivity of mule deer on the National Bison Range, Montana. J. Wild1. Manage. 32(2):344-349.

Nordberg, R. 1980. Ranger, Sioux District, Custer National Forest, Camp Crook, South Dakota. Personal Comunication.

Ozoga, J.J. 1968. Variations in microclimate in a conifer swamp deer yard in northern Michigan. J. Wild1. Manage. 32(3):574-585.

and L.W. Gysel. 1972. Response of white-tailed deer to winter weather. J. Wild1. Manage. 36(3):892-896. 
Pac, D.F. 1978. Statewide deer carcass collection. pp 199-217 in Montana deer studies, Prog. Rep., Montana Dept. Fish and Game, Proj. W-120-R-9.

Pepper, G.W. 1972. The ecology of sharp-tailed grouse during spring and summer in the aspen parklands of Saskatchewan. Saskatchewan Dept. Nat. Res., Wildl. Rep. No. 1. $55 \mathrm{pp}$.

Perry, E.S. 1935. Geology and ground water resources of southeastern Montana. Montana Bur. Mines and Geol., Memo. No. 14. $67 \mathrm{pp}$.

Pettingill, O.S. and N.R. Whitney. 1965. Birds of the Black Hills. Cornell Lab. Ornith., Sec. Pub1. No. 1. 139 pp.

Pfister, R.D., B.L. Kovalchik, S.F. Arno and R.C. Presby. 1977. Forest habitat types of Montana. U.S. Forest Service, USDA, Gen. Tech. Rep. INT-34. $173 \mathrm{pp}$.

Potter, L.D. and D.L. Green. 1964. Ecology of ponderosa pine in western North Dakota. Ecol. 45(1):10-23.

Quimby, D.C. and D.E. Johnson. 1951. Weights and measurements of Rocky Mounta in elk. J. Wildl. Manage. 15(1):57-62.

Ransom, A.B. 1965. Kidney and marrow fat as indicators of white-tailed deer condition. J. Wildl. Manage. 29(2):397-398.

- 1967. Reproductive biology of white-tailed deer in Manitoba. J. Wi d d. Manage. 31(1):114-123.

Robinette, W.L., D.A. Jones, G.Rogers and J.S. Gashwiler. 1957. Notes on tooth development and wear for Rocky Mountain mule deer. J. Wildl. Manage. 2l(2):134-153.

N.V. Hancock and D.A. Jones. 1977. The Oak Creek mule deer herd in Utah. Utah Div. Wildl. Res., Publ. 77-15. 148 pp.

Robbins, J. 1979. Uranium: Montana's next gold rush. Down to earth the magazine of Montana's environment. Environ. Info. Cent., August pp 2-9.

Rongstad, 0.J. and J.R. Tester. 1969. Movements and habitat use of whitetailed deer in Minnesota. J. Wild1. Manage. 33(2):366-379.

Rose, B.J. 1956. An evaluation of two introductions of Merriam's wild turkey into Montana. Unpubl. M.S. Thesis, Montana St. Coll., Bozeman. $37 \mathrm{pp}$.

Ross, R.L. and H.E. Hunter. 1976. Climax vegetation of Montana based on soils and climate. Soil Cons. Serv., USDA. $64 \mathrm{pp}$. 
Sanford, R.C. 1970. Skunkbush (Rhus trilobata nutt.) in the North Dakota hadlands. Unpubl. Ph.D. Thes is. North Dakota St. Univ., Fargo. 165 pp.

Saunders, A.A. 1916. Additions to the birds of Custer County. Auk 33:203-205.

Severinghaus, C.N. 1949. Tooth development and wear as criteria of age in whi te-ta iled deer. J. Wi ld1. Manage. 13(2):197-216.

. and E.L. Cheatum. 1956. Life and times of the whitetailed deer. pp. 57-186 in The deer of North America, W.P. Taylor ed. The Stackpole Co., Harrisburg, Pennsylvania. $668 \mathrm{pp}$.

Severson, K.E. and J.F. Thilenius. 1976. Classification of quaking aspen in the Black Hills and Bear Lodge Mountains. U.S. Forest Service, USDA, Res. Pap. RM-166. 24 pp.

and A.V. Carter. 1978. Movements and habitat use by mule deer in the Northern Great Plains, South Dakota. Proc. 1st Int. Rangeland Congr. pp. 466-468.

Shock, D.A. and F.R. Conley.1974. Solution mining - its promise and its problems. Proc. Soln. Mining Symp. pp. 79-97.

Short, C. 1970. Morphological development and aging of mule and whitetailed deer fetuses. J. Wild1. Manage. 34(2):383-388.

Skaar, P.D. 1975. Montana bird distribution - preliminary mapping by latilong. Bozeman, Montana. $56 \mathrm{pp}$.

Snedecor, G.W. and W.G. Cochran. 1967. Statistical methods. 6th edition. Iowa St. Univ. Press, Ames. $592 \mathrm{pp}$.

Sparrowe, R.D. and P.F. Springer. 1970. Seasonal activity patterns of whi te-tailed deer in eastern South Dakota. J. Wild1. Manage. 34(2):420-431.

Stellingwerf, R.H. 1975. Mobile 0il Corporation's Fox Hills project, uranium exploration. U.S. Forest Service, USDA, Environ. Anal. Rep. $36 \mathrm{pp}$. Stout, K.S. 1961. Montana mining law. Montana Bur. Mines and Geol., Bull.
No. 22.

Swenson, J.E. 1978a. Intake terrestrial wildlife study. Final Rep., Montana Dept. Fish and Game. $72 \mathrm{pp}$.

- 1978b. Big game survey and inventory (Deer) - Region 7, including an analys is of deer harvest data. 1960-77. Montana Dept. Fish and Game, Proj. W-130-R-9, Job I-7. $36 \mathrm{pp}$.

- 1979a. Effects of a hemorrhagic disease epizootic on a white-tailed deer population in eastern Montana. Proc. Montana Acad. Sci. 38:25-32.

- 1979b. Factors affecting status and reproduction of ospreys in Yel1 ows tone National Park. J. Wild1. Manage. 43(3):595-601. 
and S.J. Knapp. 1979. Big game survey and inventory (Deer) Region 7. Montana Dept. Fish and Game, Proj. W-130-R10, Job I-7, 32 pp.

- 1980. Wild1 ife Management Biologist, Montana Dept. Fish, WildT. and Parks, Rosebud. Personal communication.

Teer, J.G., J.W. Thomas and E.A. Walker. 1965. Ecology and management of white-tailed deer in the Llano Basin of Texas. Wildl. Mono. 15. 62 pp.

Terral, J. 1979. The hazards of uranium exploration. Rainweed Books. Slocan Park, British Columbia. 15 pp.

U.S. Dept. Commerce. 1976-79. C1 imatological data with comparative data for Ekalaka, Montana and Camp Crook, South Dakota. Nt'1. Ocean. and Atmosph. Admin. Vols. 79-82.

U.S. Fish and Wild1. Service. 1977. An environmental guide to western surface mining, part one: Federal leasable and locatable mineral regulations. U.S. Dept. Int., FWS/OBS-77/20. $70 \mathrm{pp}$.

U.S. Bureau of Reclamation. 1972. Report on resources of eastern Montana Basins. Pick-Sloan Missouri Basin Proj., Montana 91 pp.

U.S. Forest Service. 1976a. Background reports for the Sioux Planning Unit. USDA. Custer National Forest, Dickinson, North Dakota. 221 pp.

- 1976b. Environmental statement, Sioux Planning Unit. Custer National Forest, Billings, Montana. 129 pp.

Verme, L.J. 1965. Reproduction studies on penned white-tailed deer. J. Wildl. Manage. 29(1):74-79.

- 1968. An index of winter weather severity for northern deer. J. Wild1. Manage. $32(3): 566-574$.

1969. Reproductive patterns of white-tailed deer related to nutritional plane. J. Wild1. Manage. 33(4):881-887.

Visher, J.E. 1911. Annotated list of the birds of Harding County, South Dakota. Auk 28(1):5-16.

- 1912. Additions to a list of birds of Harding County, northwestern South Dakota. Auk 29:110-111.

- 1913. Additions to a list of birds of Harding County. northwestern South Dakota. II. Auk 30:281.

Wagner, R.H. and T.G. Marples. 1966. The breeding success of various passerine birds under chronic gamma irradiation stress. Auk 83(3): 437-440. 
Wentland, H.J. 1979. Big game surveys and inventory (Antelope) - Region 7. Montana Dept. Fish and Game, Proj. W-130-R-10. Job 7. 28 pp.

Wetzel, J.F., J.R. Wambaugh and J.M. Peek. 1975. Appraisal of white-tailed deer winter habitats in northeastern Minnesota. J. Wildl. Manage. $39(1): 59-66$.

Wilkins, B.T. 1957. Range use, food habits and agricultural relationships of mule deer, Bridger Mountains, Montana. J. Wild1. Manage. 21(2): 159-169.

Willard, W.K. 1963. Relative sensitivity of nestlings of wild passerine birds to gamma radiation. pp. 345-349 in Radioecology, v. Schultz and A.W. Klement, Jr., eds., Reinhold, New York.

Woodgerd, W. 1952. Food habits of the golden eagle. J. Wildl. Manage. $16: 457-459$.

Wyoming Mineral Corporation. 1976. Uranium solution mining. Lakewood, Colorado. $12 \mathrm{pp}$. 

APPENDIX 

Table 1. Climatological data from September 1976 through August 1979 for Ekalaka, Montana. a

\begin{tabular}{|c|c|c|c|c|c|c|c|c|c|}
\hline \multirow[b]{2}{*}{ Month } & \multicolumn{2}{|c|}{ Temperature } & \multicolumn{2}{|c|}{ Precipitation } & \multirow[b]{2}{*}{ Month } & \multicolumn{2}{|c|}{ Temperature } & \multicolumn{2}{|c|}{ Precipitation } \\
\hline & Average & $\begin{array}{l}\text { Dep. from } \\
\text { Norma } 1\end{array}$ & Total & $\begin{array}{l}\text { Dep. from } \\
\text { Normal }\end{array}$ & & Average & $\begin{array}{l}\text { Dep. from } \\
\text { Normal }\end{array}$ & Tota 1 & $\begin{array}{l}\text { Dep. from } \\
\text { Normal }\end{array}$ \\
\hline $\begin{array}{c}\text { September } \\
1976 \\
1977 \\
1978\end{array}$ & $\begin{array}{l}62.0 \\
57.7 \\
62.2\end{array}$ & $\begin{array}{r}4.5 \\
.2 \\
4.7\end{array}$ & $\begin{array}{l}.49 \\
3.33 \\
1.70\end{array}$ & $\begin{array}{r}-.92 \\
1.92 \\
.29\end{array}$ & $\begin{array}{c}\text { March } \\
1977 \\
1978 \\
1979\end{array}$ & $\begin{array}{l}34.6 \\
32.1 \\
30.9\end{array}$ & $\begin{array}{l}6.0 \\
3.5 \\
2.3\end{array}$ & $\begin{array}{r}1.39 \\
.06 \\
.65\end{array}$ & $\begin{array}{r}.76 \\
-.57 \\
.02\end{array}$ \\
\hline $\begin{array}{c}\text { October } \\
1976 \\
1977 \\
1978\end{array}$ & $\begin{array}{l}43.0 \\
47.4 \\
46.5\end{array}$ & $\begin{array}{r}-4.0 \\
.4 \\
-.5\end{array}$ & $\begin{array}{r}.68 \\
1.85 \\
.43\end{array}$ & $\begin{array}{l}-.05 \\
1.12 \\
-.30\end{array}$ & $\begin{array}{c}\text { Apri1 } \\
1977 \\
1978 \\
1979\end{array}$ & $\begin{array}{l}48.4 \\
43.5 \\
40.9\end{array}$ & $\begin{array}{r}5.6 \\
-1.9\end{array}$ & $\begin{array}{r}.21 \\
1.19 \\
.81\end{array}$ & $\begin{array}{r}-1.09 \\
-.11 \\
-.49\end{array}$ \\
\hline $\begin{array}{c}\text { November } \\
1976 \\
1977 \\
1978\end{array}$ & $\begin{array}{l}25.7 \\
29.0 \\
26.3\end{array}$ & $\begin{array}{l}-5.7 \\
-2.4 \\
-5.1\end{array}$ & $\begin{array}{r}.13 \\
.83 \\
1.88\end{array}$ & $\begin{array}{r}-.44 \\
.26 \\
1.31\end{array}$ & $\begin{array}{l}\text { May } \\
1977 \\
1978 \\
1979\end{array}$ & $\begin{array}{l}61.1 \\
54.3 \\
51.6\end{array}$ & $\begin{array}{r}7.5 \\
.7 \\
-2.0\end{array}$ & $\begin{array}{r}.98 \\
5.92 \\
1.98\end{array}$ & $\begin{array}{r}-1.27 \\
3.67 \\
-.27\end{array}$ \\
\hline $\begin{array}{c}\text { December } \\
1976 \\
1977 \\
1978\end{array}$ & $\begin{array}{l}23.7 \\
17.3 \\
12.9\end{array}$ & $\begin{array}{r}.8 \\
-5.6 \\
-10.0\end{array}$ & $\begin{array}{r}.35 \\
1.35 \\
.34\end{array}$ & $\begin{array}{r}-.05 \\
.05 \\
-.06\end{array}$ & $\begin{array}{l}\text { June } \\
1977 \\
1978 \\
1979\end{array}$ & $\begin{array}{l}67.5 \\
62.8 \\
64.2\end{array}$ & $\begin{array}{r}5.6 \\
.9 \\
2.3\end{array}$ & $\begin{array}{l}3.34 \\
2.26 \\
2.43\end{array}$ & $\begin{array}{l}-.33 \\
-1.41 \\
-1.24\end{array}$ \\
\hline $\begin{array}{c}\text { January } \\
1977 \\
1978 \\
1979\end{array}$ & $\begin{array}{l}8.7 \\
9.2 \\
2.4\end{array}$ & $\begin{array}{r}-8.8 \\
-8.3 \\
-15.1\end{array}$ & $\begin{array}{r}1.11 \\
.74 \\
.39\end{array}$ & $\begin{array}{r}.65 \\
. .18 \\
-.07\end{array}$ & $\begin{array}{l}\text { July } \\
1977 \\
1978 \\
1979\end{array}$ & $\begin{array}{l}72.1 \\
68.8 \\
71.3\end{array}$ & $\begin{array}{r}1.6 \\
-1.7 \\
.8\end{array}$ & $\begin{array}{l}.94 \\
2.23 \\
1.89\end{array}$ & $\begin{array}{r}-.95 \\
.34 \\
0.00\end{array}$ \\
\hline $\begin{array}{c}\text { February } \\
1977 \\
1978 \\
1979\end{array}$ & $\begin{array}{l}30.1 \\
12.4 \\
15.1\end{array}$ & $\begin{array}{r}7.6 \\
-10.1 \\
-7.4\end{array}$ & $\begin{array}{l}.31 \\
2.01 \\
1.34\end{array}$ & $\begin{array}{r}-.10 \\
1.60 \\
.93\end{array}$ & $\begin{array}{r}\text { August } \\
1977 \\
1978 \\
1979\end{array}$ & $\begin{array}{l}64.4 \\
68.6 \\
67.9\end{array}$ & $\begin{array}{r}-5.1 \\
-.9 \\
-1.6\end{array}$ & $\begin{array}{l}1.20 \\
1.05 \\
1.20\end{array}$ & $\begin{array}{l}-.30 \\
-.45 \\
-.30\end{array}$ \\
\hline
\end{tabular}

a Data compiled by U.S. Department of Commerce.

b Monthly normals based on the years 1941-1970. 
Table 2. Climatological data from September 1976 through August 1979 for Camp Crook, Soutn Dakota. ${ }^{a}$

\begin{tabular}{|c|c|c|c|c|c|c|c|c|c|}
\hline \multirow[b]{2}{*}{ Month } & \multicolumn{2}{|c|}{ Temperature } & \multicolumn{2}{|c|}{ Precipitation } & \multirow[b]{2}{*}{ Month } & \multicolumn{2}{|c|}{ Temperature } & \multicolumn{2}{|c|}{ Precipitation } \\
\hline & Average & $\begin{array}{l}\text { Dep. fromb } \\
\text { Norma } 1\end{array}$ & Total & $\begin{array}{l}\text { Dept. from } \\
\text { Normal }\end{array}$ & & Average & $\begin{array}{l}\text { Dep. from } \\
\text { Norma } ~\end{array}$ & Total & $\begin{array}{l}\text { Dep. from } \\
\text { Normal }\end{array}$ \\
\hline $\begin{array}{c}\text { September } \\
1976 \\
1977 \\
1978\end{array}$ & $\begin{array}{l}61.5 \\
58.9 \\
62.8\end{array}$ & $\begin{array}{l}- \\
-\end{array}$ & $\begin{array}{l}.46 \\
2.63 \\
1.49\end{array}$ & $\begin{array}{r}-.74 \\
1.43 \\
.29\end{array}$ & $\begin{array}{c}\text { March } \\
1977 \\
1978 \\
1979\end{array}$ & $\begin{array}{c}35.2 \\
\overline{2} \\
29.2\end{array}$ & $\begin{array}{l}- \\
-\end{array}$ & $\begin{array}{r}1.46 \\
.24 \\
.22\end{array}$ & $\begin{array}{r}.97 \\
-.25 \\
-.27\end{array}$ \\
\hline $\begin{array}{c}\text { October } \\
1976 \\
1977 \\
1978\end{array}$ & $\begin{array}{l}43.5 \\
47.6 \\
47.8\end{array}$ & - & $\begin{array}{r}.51 \\
2.37 \\
.03\end{array}$ & $\begin{array}{l}-.13 \\
1.73 \\
-.61\end{array}$ & $\begin{array}{c}\text { Apri1 } \\
1977 \\
1978 \\
1979\end{array}$ & $\begin{array}{l}47.9 \\
44.6 \\
41.5\end{array}$ & $\begin{array}{l}- \\
\text { - }\end{array}$ & $\begin{array}{r}.21 \\
1.42 \\
.44\end{array}$ & $\begin{array}{r}-1.10 \\
.11 \\
-.87\end{array}$ \\
\hline $\begin{array}{c}\text { November } \\
1976 \\
1977 \\
1978\end{array}$ & $\begin{array}{l}27.1 \\
29.5 \\
26.3\end{array}$ & $\begin{array}{l}- \\
-\end{array}$ & $\begin{array}{r}.12 \\
.94 \\
1.32\end{array}$ & $\begin{array}{r}-.28 \\
.54 \\
.92\end{array}$ & $\begin{array}{l}\text { May } \\
1977 \\
1978 \\
1979\end{array}$ & $\begin{array}{l}61.0 \\
54.5 \\
51.9\end{array}$ & $\begin{array}{l}- \\
-\end{array}$ & $\begin{array}{l}1.33 \\
5.82 \\
1.09\end{array}$ & $\begin{array}{r}-.90 \\
3.59 \\
-1.14\end{array}$ \\
\hline $\begin{array}{c}\text { December } \\
1976 \\
1977 \\
1978\end{array}$ & $\begin{array}{l}25.5 \\
16.5 \\
13.1\end{array}$ & $\begin{array}{l}- \\
-\end{array}$ & $\begin{array}{l}.22 \\
.75 \\
.09\end{array}$ & $\begin{array}{r}-.07 \\
.46 \\
-.20\end{array}$ & $\begin{array}{l}\text { June } \\
1977 \\
1978 \\
1979\end{array}$ & $\begin{array}{l}69.3 \\
62.0 \\
63.6\end{array}$ & - & $\begin{array}{l}1.85 \\
1.33 \\
1.27\end{array}$ & $\begin{array}{l}-1.34 \\
-1.86 \\
-1.92\end{array}$ \\
\hline $\begin{array}{c}\text { January } \\
1977 \\
1978 \\
1979\end{array}$ & $\begin{array}{l}8.1 \\
6.6 \\
2.0\end{array}$ & $\begin{array}{l}- \\
-\end{array}$ & $\begin{array}{l}.53 \\
.07 \\
.09\end{array}$ & $\begin{array}{r}.18 \\
-.28 \\
-.26\end{array}$ & $\begin{array}{l}\text { July } \\
1977 \\
1978 \\
1979\end{array}$ & $\begin{array}{l}73.3 \\
68.6 \\
68.9\end{array}$ & $\begin{array}{l}- \\
\text { - }\end{array}$ & $\begin{array}{r}.98 \\
3.76 \\
3.99\end{array}$ & $\begin{array}{l}-.73 \\
2.05 \\
2.28\end{array}$ \\
\hline $\begin{array}{c}\text { February } \\
1977 \\
1978 \\
1979\end{array}$ & $\begin{array}{r}31.1 \\
11.7 \\
9.4\end{array}$ & $\begin{array}{l}- \\
-\end{array}$ & $\begin{array}{r}.07 \\
1.04 \\
.94\end{array}$ & $\begin{array}{r}-.26 \\
.71 \\
.61\end{array}$ & $\begin{array}{r}\text { August } \\
1977 \\
1978 \\
1979\end{array}$ & $\begin{array}{l}64.5 \\
68.8 \\
68.3\end{array}$ & $\begin{array}{l}- \\
\text { - }\end{array}$ & $\begin{array}{l}.95 \\
.46 \\
.63\end{array}$ & $\begin{array}{r}-.58 \\
-1.07 \\
-.90\end{array}$ \\
\hline
\end{tabular}

a Data compiled by U.S. Department of Commerce.

b 30-year average temperatures unavailable for Camp Crook.

C Normals are based on average monthly temperatures and precipitation for the years 1941-1970. 
Table 3. Constancy and frequency of low-growing vegetation on 4 vegetational communities with an overstory of trees and/or shrubs as determined from examination of $202 \times 5$ decimeter plots on each of 26 sites.

\begin{tabular}{|c|c|c|c|c|}
\hline & P.Pine-Xeric & P.Pine-Mesic & & \\
\hline Taxa & $\begin{array}{c}\text { Pipo/Aqsp } \\
\text { ht } \\
(10)^{a}\end{array}$ & $\begin{array}{c}\text { Pipo/syal } \\
\text { ht } \\
\text { (11) }\end{array}$ & $\begin{array}{c}\text { Frpe/Acnu } \\
\text { ct } \\
\text { (3) }\end{array}$ & $\begin{array}{c}\text { Syal/Popr } \\
\text { ct } \\
\text { (2) }\end{array}$ \\
\hline
\end{tabular}

GRASSES \& GRASSLIKE:

Agropyron spp.

Agropyron smithii

Agropuron spicatum

Andropogon scoparius

Aristida longiseta

Bouteloua curtipendula

Bouteloua gracilis

Bromus japonicus

Bromus tectorum

Calamovilfa longifolia

Carex spp.

Elymus spp.

Koeleria cristata

Muhlenbergia cuspidata

Poa pratensis

Stipa comata

Stipa spartea

Stipa viridula

Unidentified Grasses

TOTAL GRASSES

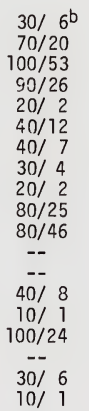

$100 / 99$

$73 / 14$
$27 / 12$
$18 / 4$
$9 / 2$
$9 / 2$
--
$9 / \operatorname{tr}$
$9 / 1$
--
$9 / 4$
$91 / 40$
--
$36 / 14$
--
$82 / 32$
$45 / 6$
$27 / 9$
$91 / 45$
$64 / 15$

$100 / 95$

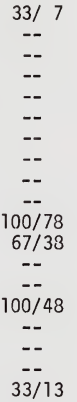

$100 / 98$
$50 / 20$

$100 / 45$

--

$--$

--

--

$--$

$--$

$50 / 20$

$50 / 5$

$--$

$100 / 40$

--

$50 / 22$

$50 / 30$

$100 / 95$

FORBS

Achillea millejolium

Allium textile

Anemone patens

Antennaria parvifolia

Antennaria rosea

Apociynum spp.
20/ 3

$10 / 2$

$10 / 6$

$--$

$\overline{10 / 1}$
$64 / 26$

18/ 1

27/ 4

$45 / 5$

$27 / 2$
33/ 3

$100 / 17$

--

$-$

$-$

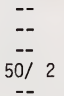


Tabie 3. Continued

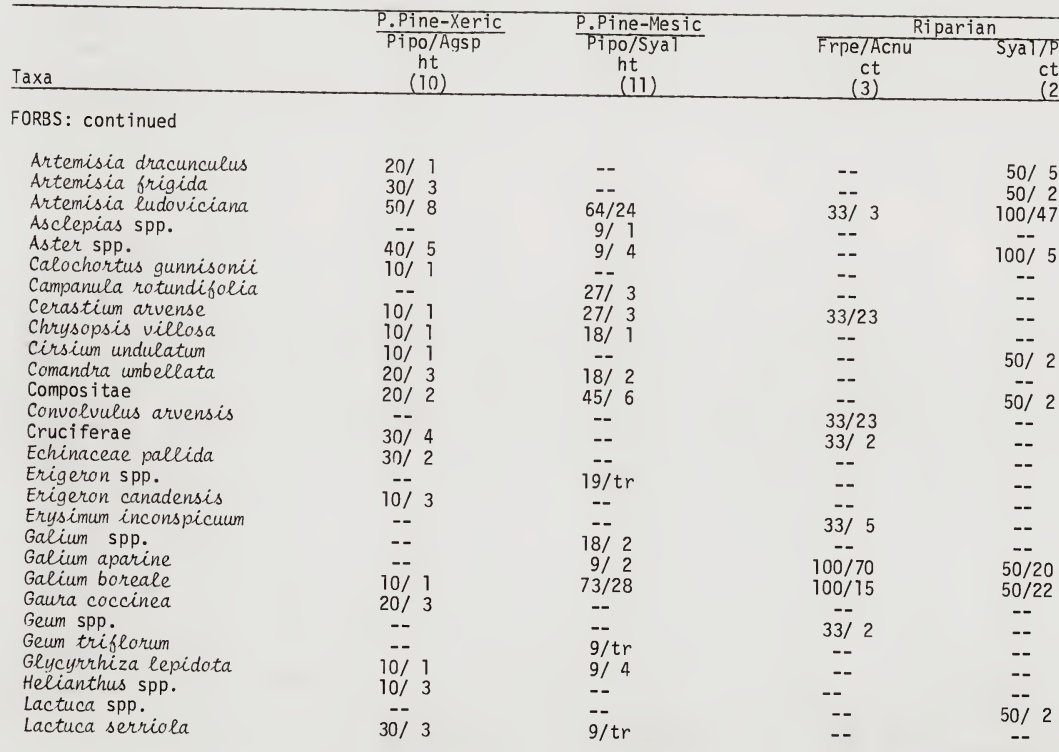


Table 3. Continued

\begin{tabular}{|c|c|c|c|c|}
\hline & P.Pine-Xeric & P.Pine-Mesic & & \\
\hline Taxa & $\begin{array}{c}\text { Pipo/Agsp } \\
\text { ht } \\
\text { (10) }\end{array}$ & $\begin{array}{c}\text { Pipo/Syal } \\
\text { ht } \\
\text { (11) }\end{array}$ & $\begin{array}{c}\text { Frpe/Acnu } \\
\text { ct } \\
\text { (3) }\end{array}$ & $\begin{array}{l}\text { Syal/Popr } \\
\text { ct } \\
\text { (2) }\end{array}$ \\
\hline
\end{tabular}

FORBS: continued

\begin{tabular}{|c|c|c|c|c|}
\hline Labiatae & -- & -- & $33 / 12$ & $50 / 20$ \\
\hline Leguminosae & $10 / 1$ & $18 / 5$ & -- & $20 / 2$ \\
\hline Lupinus argenteus & $10 / 1$ & $9 / \mathrm{tr}$ & -- & -- \\
\hline Mentha arvensis & -- & $9 / 1$ & $23 / 7$ & -- \\
\hline Melilotus officinalis & $20 / 4$ & - & $33 / 3$ & -- \\
\hline Monarda fistulosa & - & -- & -- & $50 / 45$ \\
\hline Orthocarpus luteus & -- & $9 / \mathrm{tr}$ & $33 / 5$ & -- \\
\hline Osmorhiza spp. & -- & -- & -- & -- \\
\hline Penstemon spp. & -- & $9 / 2$ & -- & -- \\
\hline Petalostemon purpureum & -- & $9 / 1$ & -- & -- \\
\hline Plox hoodii & $30 / 5$ & $27 / 3$ & -- & -- \\
\hline Phlox longifolia & $10 / 1$ & $18 / 2$ & -- & -- \\
\hline Plantago purshii & $10 / 1$ & -- & $33 / 8$ & -- \\
\hline Potentilla spp. & -- & -- & -- & -- \\
\hline Psoralea argophylla & $30 / 8$ & $18 / 2$ & -- & -- \\
\hline Psoralea esculenta & $70 / 9$ & $18 / 3$ & $33 / 3$ & -- \\
\hline Ranunculus spp. & -- & -- & -- & -- \\
\hline Ratibida columnifera & -- & -- & -- & -- \\
\hline Senecio spp. & -- & 9/ 1 & $100 / 25$ & -- \\
\hline Smilicina stellata & -- & $45 / 10$ & -- & -- \\
\hline Solidago spp. & $10 / 1$ & -- & -- & -- \\
\hline Sphaeralcea coscinea & $10 / 1$ & -- & -- & -- \\
\hline Spiranthea spp. & -- & $9 / \mathrm{tr}$ & $67 / 30$ & $50 / 2$ \\
\hline Taraxicum officinale & $20 / 1$ & $55 / 4$ & $67 / 20$ & -- \\
\hline Thalictrum venulosum & -- & $18 / 2$ & -- & -- \\
\hline Thermopsis rhombifolia & $20 / 7$ & $9 / 5$ & $33 / 3$ & $50 / 10$ \\
\hline Tragopogon dubius & $50 / 3$ & $45 / 6$ & -- & -- \\
\hline Urtica dioica & -- & -- & $33 / 2$ & $100 / 5$ \\
\hline Vicia americana & $90 / 23$ & $64 / 14$ & & \\
\hline
\end{tabular}


Table 3. Continued

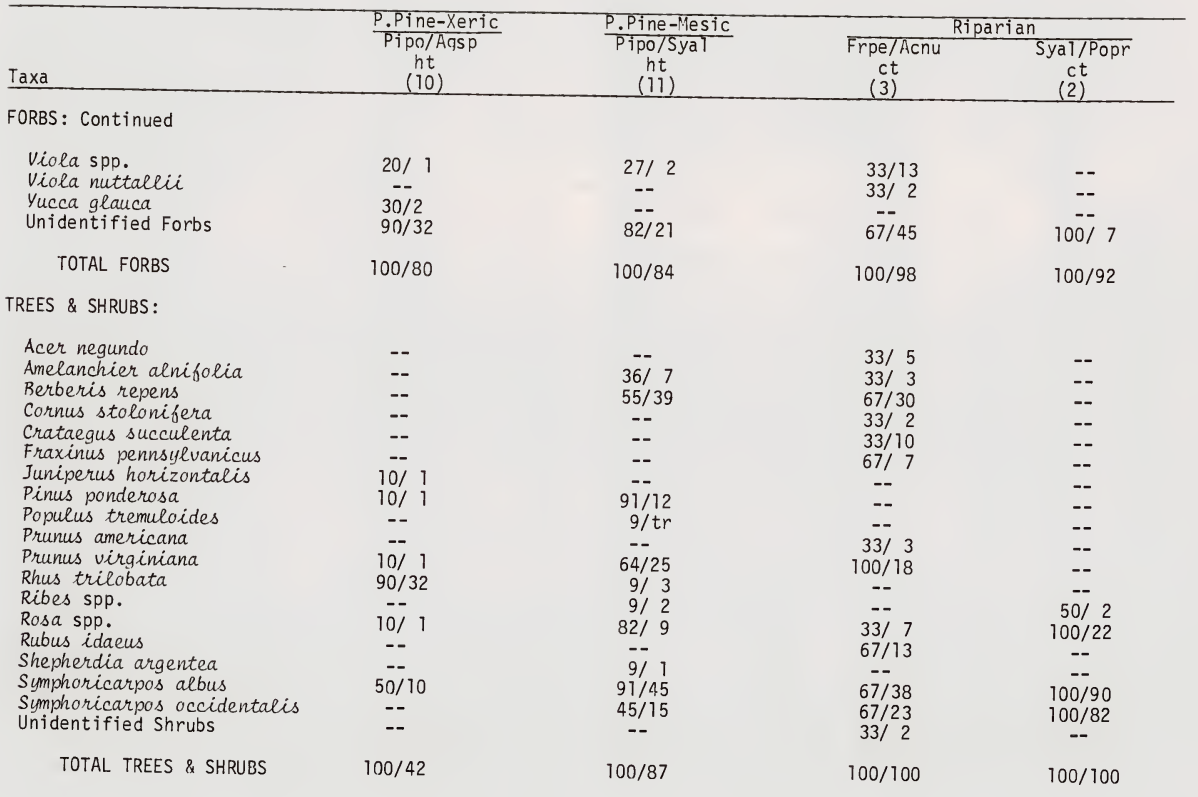


Table 3. Continued

\begin{tabular}{|c|c|c|c|c|}
\hline Taxa & $\begin{array}{c}\text { P.Pine-Xeric } \\
\text { Pipo/Agsp } \\
h t \\
(10) \\
\end{array}$ & $\begin{array}{c}\text { P.Pine-Mesic } \\
\text { Pipo/Syal } \\
\text { ht } \\
\text { (11) }\end{array}$ & $\begin{array}{c}\text { Frpe/Acnu } \\
\text { ct } \\
(3)\end{array}$ & $\begin{array}{c}\text { Syal/Popr } \\
\text { ct } \\
\text { (2) } \\
\end{array}$ \\
\hline $\begin{array}{l}\text { Bare ground } \\
\text { Rock } \\
\text { Club moss } \\
\text { Lichens } \\
\text { Ground litter } \\
\text { Standing litter }\end{array}$ & $\begin{array}{c}80 / 53 \\
90 / 35 \\
-- \\
20 / 2 \\
100 / 98 \\
100 / 42\end{array}$ & $\begin{array}{c}55 / 4 \\
\overline{9} \\
-- \\
100 / 99 \\
91 / 38\end{array}$ & $\begin{array}{c}67 / 3 \\
-- \\
-- \\
-- \\
100 / 100 \\
100 / 25\end{array}$ & $\begin{array}{l}-- \\
-- \\
-- \\
-- \\
100 / 100 \\
100 / 87\end{array}$ \\
\hline
\end{tabular}

a Number of sites sampled.

b Constancy (percent occurrence among sites)/Average frequency (Percent occurrence among plots). c Trace (a value less than 0.5 percent). 
Table 4. Constancy and frequency of low-growing vegetation on 5 vegetational communities in the grassland/ badland complex of Long Pines study area as determined from examination of $202 \times 5$ decimeter plots at each of 22 sites.

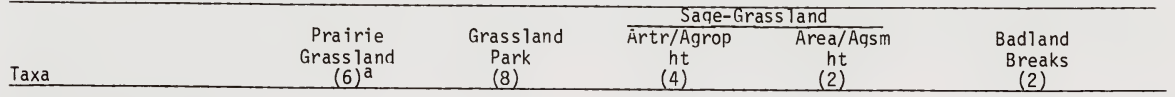

GRASSES \& GRASSLIKE:

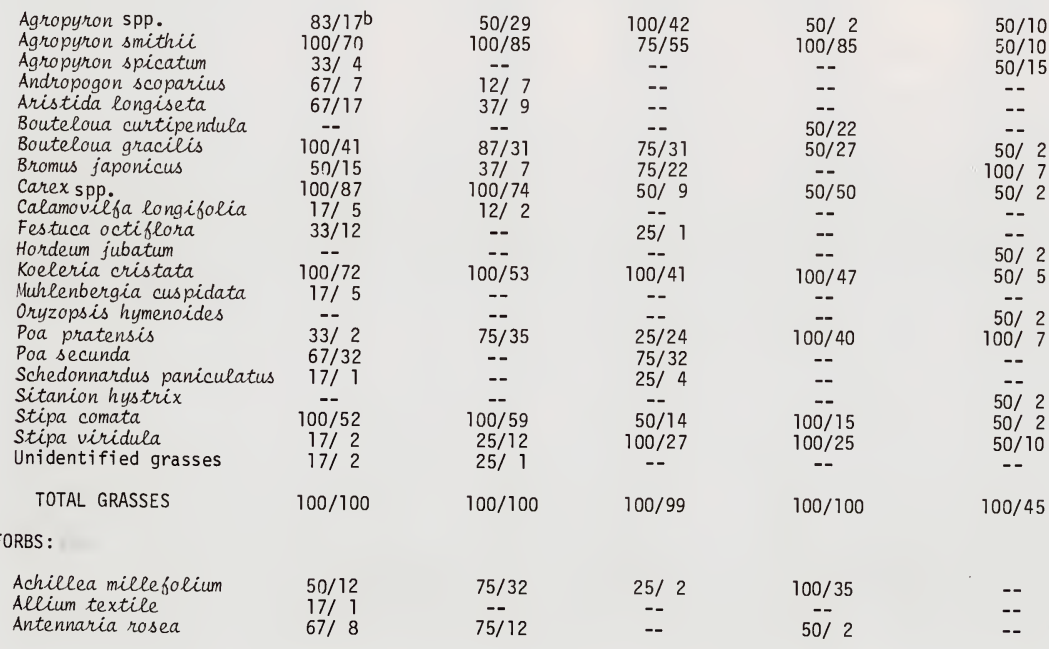


Table 4. Continued

\begin{tabular}{|c|c|c|c|c|c|}
\hline & & & Sage & and & \\
\hline
\end{tabular}

FORBS: continued

Artemisia dracunculus

Artemisia frigida

Artemisia ludoviciana

Aster spp.

Atriplex nuttalli

Cerastium arvense

Chrysops is villosa

Cirsium undulatum

Compositae

Comandra umbellata

Cruciferae

Echinaceae pallida

Erigeron spp.

Erigeron canadensis

Erigeron strigosus

Eriogonum spp.

Eurotia lanata

Galium spp.

Gaura coccinea

seum triflorum

Grindelia squarrosa

Gutierresia sarothrae

Haplopappus spinulosus

Helianthus spp.

Lactuca spp.

Lactuca serriola

Leguminosae

Lupinus argenteus

$\begin{array}{cc}50 / 5 & 37 / 7 \\ 100 / 38 & 87 / 31 \\ 33 / 2 & 75 / 33 \\ 17 / 4 & 75 / 32 \\ -- & -- \\ -- & 37 / 7 \\ 05 / 12 & 25 / 6 \\ -- & 12 / 2 \\ 17 / 2 & 12 / 11 \\ -- & 12 / 2 \\ 33 / 2 & -- \\ 67 / 17 & 62 / 6 \\ 25 / 1 & 12 / 1 \\ 17 / 6 & 12 / 1 \\ 17 / 1 & 12 / 1 \\ 17 / 2 & -- \\ -- & -- \\ 17 / 6 & 12 / 1 \\ 33 / 2 & 12 / 11 \\ 17 / 1 & 12 / 6 \\ -- & -- \\ 33 / 37 & 12 / 2 \\ 17 / 2 & 12 / 1 \\ 17 / 2 & -- \\ -- & 25 / 1 \\ -- & 12 / 6 \\ 33 / 2 & 62 / 12 \\ 17 / 1 & 12 / 1\end{array}$

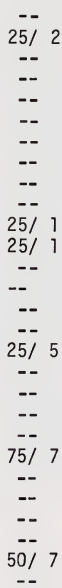

$50 / 2$

$50 / 2$

$100 / 47$

$50 / 32$

$50 / 2$

--

$50 / 5$

$--$

$-$

$--$

$--$

$-$

$--$

$--$

$-$

$--$

--

$--$

$--$

$-$

$100 / 12$

$50 / 10$
$-$

$-$

$50 / 5$

$--$

$50 / 2$

--

$-$

--

--

$50 / 27$

--

$--$

$50 / 5$

$100 / 5$

--

$100 / 5$

$50 / 2$ 
Table 4. Continued

\begin{tabular}{|c|c|c|c|c|c|}
\hline Taxa & $\begin{array}{c}\text { Prairie } \\
\text { Grass land } \\
(6) a \\
\end{array}$ & $\begin{array}{c}\text { Grass land } \\
\text { Park } \\
\text { (8) }\end{array}$ & $\begin{array}{l}\text { Sage- } \\
\text { Artr/Agrop } \\
\text { ht } \\
(4) \\
\end{array}$ & $\begin{array}{c}\text { nd } \\
\text { Area/Agsm } \\
\text { ht } \\
\text { (2) }\end{array}$ & $\begin{array}{l}\text { Badl and } \\
\text { Breaks } \\
\text { (2) }\end{array}$ \\
\hline \multicolumn{6}{|l|}{ FORBS: Continued } \\
\hline Lygodesmia juncea & $50 / 12$ & $37 / 2$ & - & - & - \\
\hline Melilotus officinalis & $17 / 1$ & - & $25 / 12$ & - & $50 / 10$ \\
\hline Oenothera spp. & - & - & $25 / 1$ & - & - \\
\hline Oenothera serrulata & $17 / 1$ & - & - & - & - \\
\hline Opuntia polycantha & - & - & $75 / 7$ & - & - \\
\hline Orthocarpus luteus & $100 / 12$ & $37 / 5$ & $25 / 1$ & $50 / 2$ & - \\
\hline Penstemon spp. & - & $12 / 2$ & - & - & - \\
\hline Petalostemon purpureum & $50 / 17$ & $25 / 10$ & - & - & - \\
\hline Phlox hoodii & $83 / 21$ & $12 / 2$ & $50 / 6$ & $50 / 2$ & $50 / 5$ \\
\hline Phlox longifolia & $33 / 3$ & $37 / 11$ & - & - & - \\
\hline Plantago purshii & $83 / 24$ & $12 / 4$ & $25 / 19$ & - & - \\
\hline Psoralea argophylla & $67 / 17$ & $75 / 17$ & $25 / 1$ & $50 / 5$ & - \\
\hline Psoralea esculenta & $67 / 10$ & $75 / 18$ & - & $50 / 15$ & - \\
\hline Ratibida columnifera & $67 / 7$ & $75 / 21$ & - & - & - \\
\hline Salsola kali & - & - & - & - & $50 / 5$ \\
\hline Solidago spp. & $33 / 5$ & $50 / 6$ & - & $50 / 2$ & - \\
\hline Sphaeralcea coccinea & $30 / 14$ & 25/ 4 & $50 / 12$ & - & - \\
\hline Taraxicum offinale & - & $12 / 1$ & - & - & - \\
\hline Thermops is rhombifolia & - & $25 / 9$ & $50 / 2$ & $\overline{-}$ & - \\
\hline Tragopogon dubius & $17 / 1$ & $50 / 6$ & $\begin{array}{ll}50 / 2 \\
25 / 2\end{array}$ & $50 / 5$ & - \\
\hline $\begin{array}{l}\text { Vicia americana } \\
\text { Viola nuttallii }\end{array}$ & - & $12 \overline{1} 1$ & $25 / 2$ & $\begin{array}{l}50 / 10 \\
50 / 2\end{array}$ & - \\
\hline Unidentified Forbs & $83 / 27$ & $62 / 18$ & $100 / 21$ & $100 / 32$ & $50 / 5$ \\
\hline TOTAL FORBS & $100 / 96$ & $100 / 99$ & $100 / 71$ & $100 / 77$ & $100 / 62$ \\
\hline
\end{tabular}


Table 4. Continued

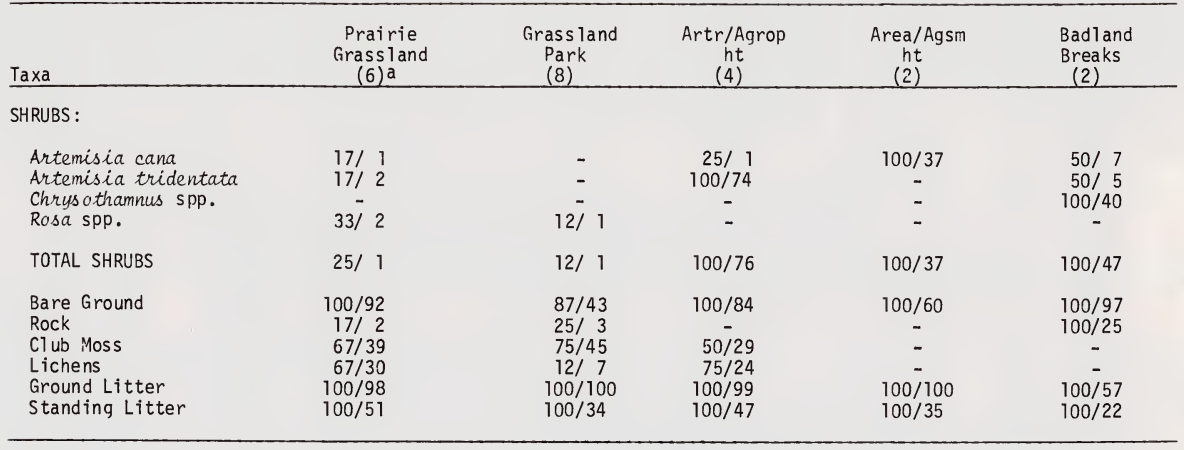

a Number of sites sampled.

b Constancy (percent occurrence among sites) /Average frequency (percent occurrence among plots). 
Table 5. Seasonal and annual distribution by time of day of white-tailed deer observed from vehicle surveys and relocations of radioed deer.

\begin{tabular}{lccccc}
\hline & $\begin{array}{c}\text { Fal1 } \\
663(88)^{\mathrm{a}}\end{array}$ & $\begin{array}{c}\text { Winter } \\
328(116)\end{array}$ & $\begin{array}{c}\text { Spring } \\
672(191)\end{array}$ & $\begin{array}{c}\text { Summer } \\
446(147)\end{array}$ & $\begin{array}{c}\text { Annua1 } \\
2,109(542)\end{array}$ \\
\hline $\begin{array}{l}\text { Early Morning } \\
-0800 \mathrm{hrs} .\end{array}$ & $15(31)^{\mathrm{b}}$ & $1(2)$ & $44(36)$ & $19(32)$ & $20(25)$ \\
$\begin{array}{l}\text { Late Morning } \\
\text { 0801-1200 hrs. }\end{array}$ & $12(26)$ & $32(51)$ & $2(18)$ & $2(10)$ & $12(26)$ \\
$\begin{array}{l}\text { Afternoon } \\
1201-1600 \text { hrs. }\end{array}$ & $26(20)$ & $47(33)$ & $10(20)$ & $5(18)$ & $22(23)$ \\
$\begin{array}{l}\text { Evening } \\
1601 \mathrm{hrs}+\end{array}$ & $46(23)$ & $21(15)$ & $44(26)$ & $74(39)$ & $46(26)$ \\
\hline
\end{tabular}

a Sample size: vehicle surveys (relocations of radioed deer).

b Percent of observations: vehicle surveys (radioed deer). 

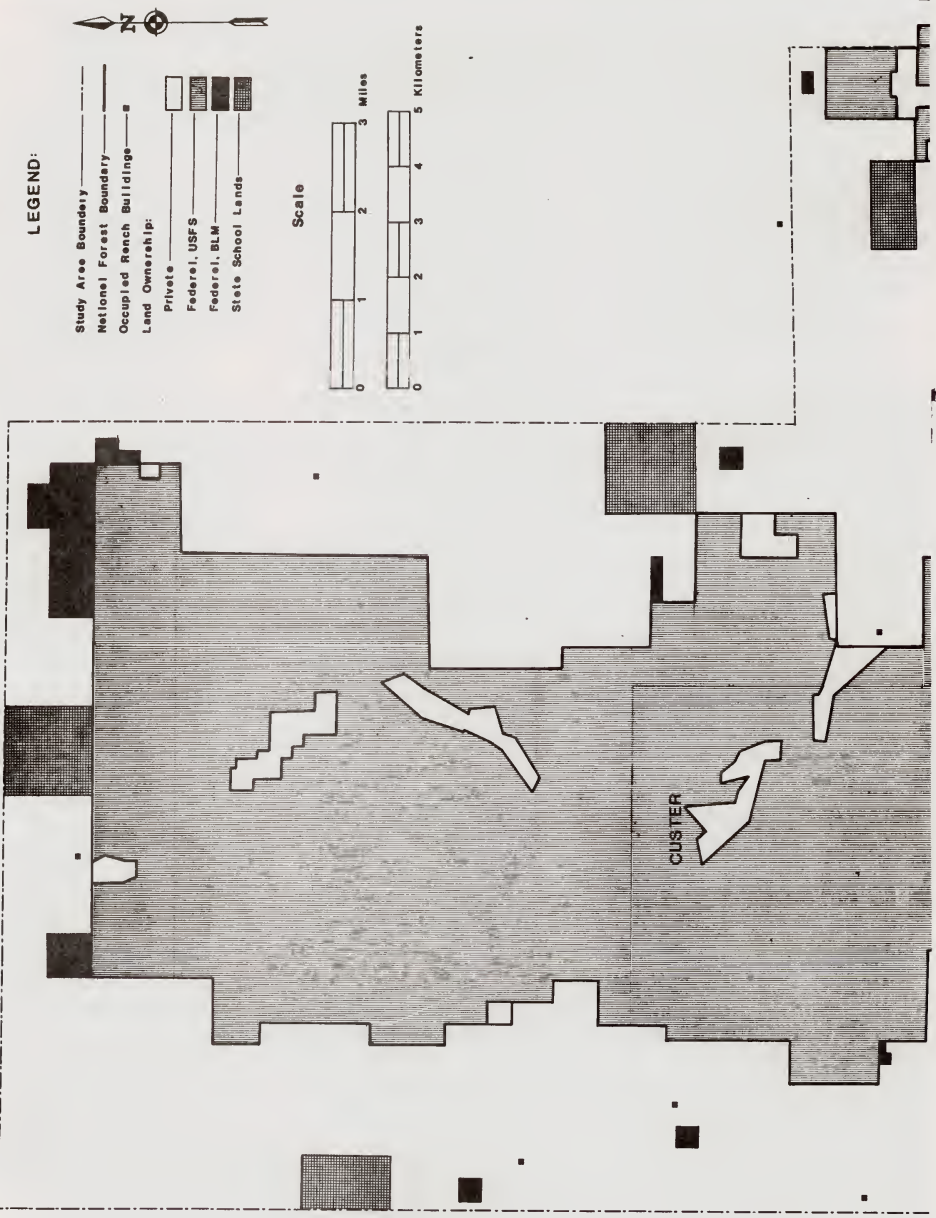

Appendix Figure 1. Landownership in the Long Pines study area. 


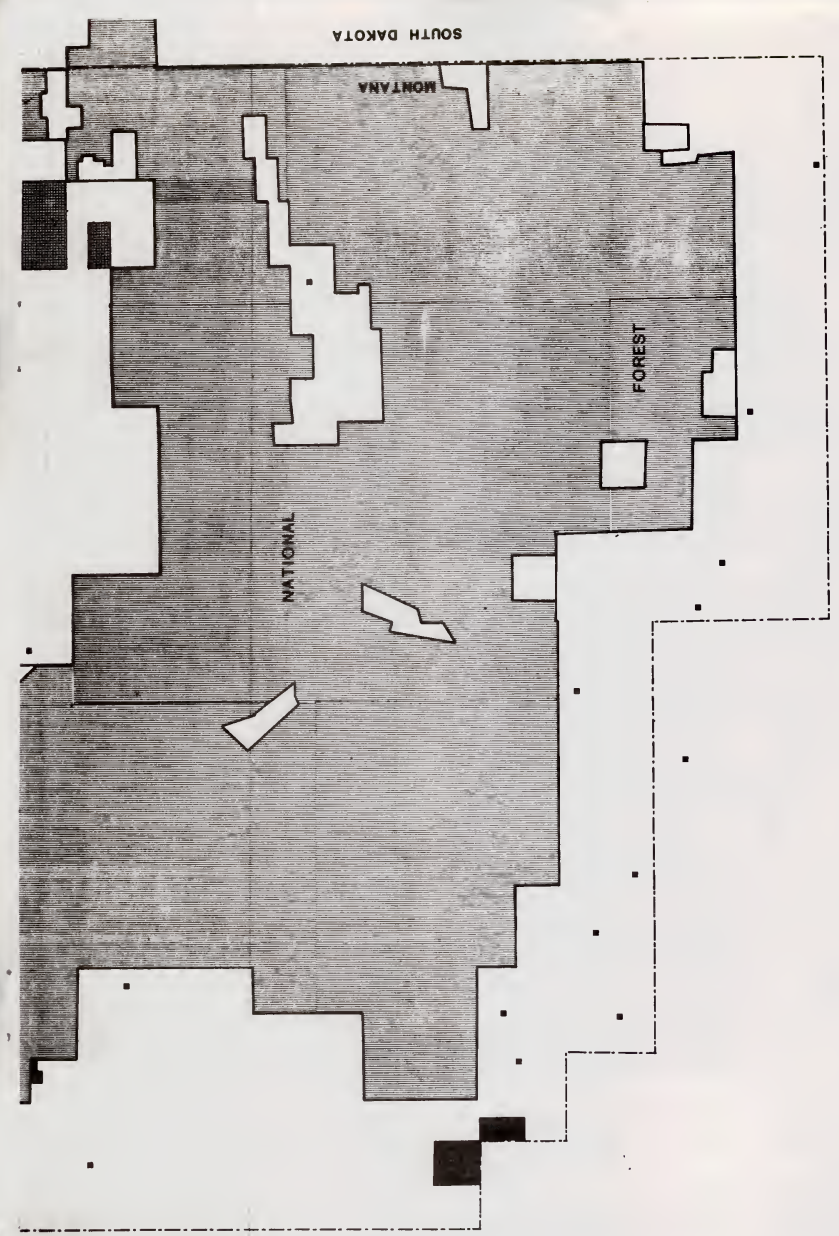

Appendix Figure 1 (continued). 



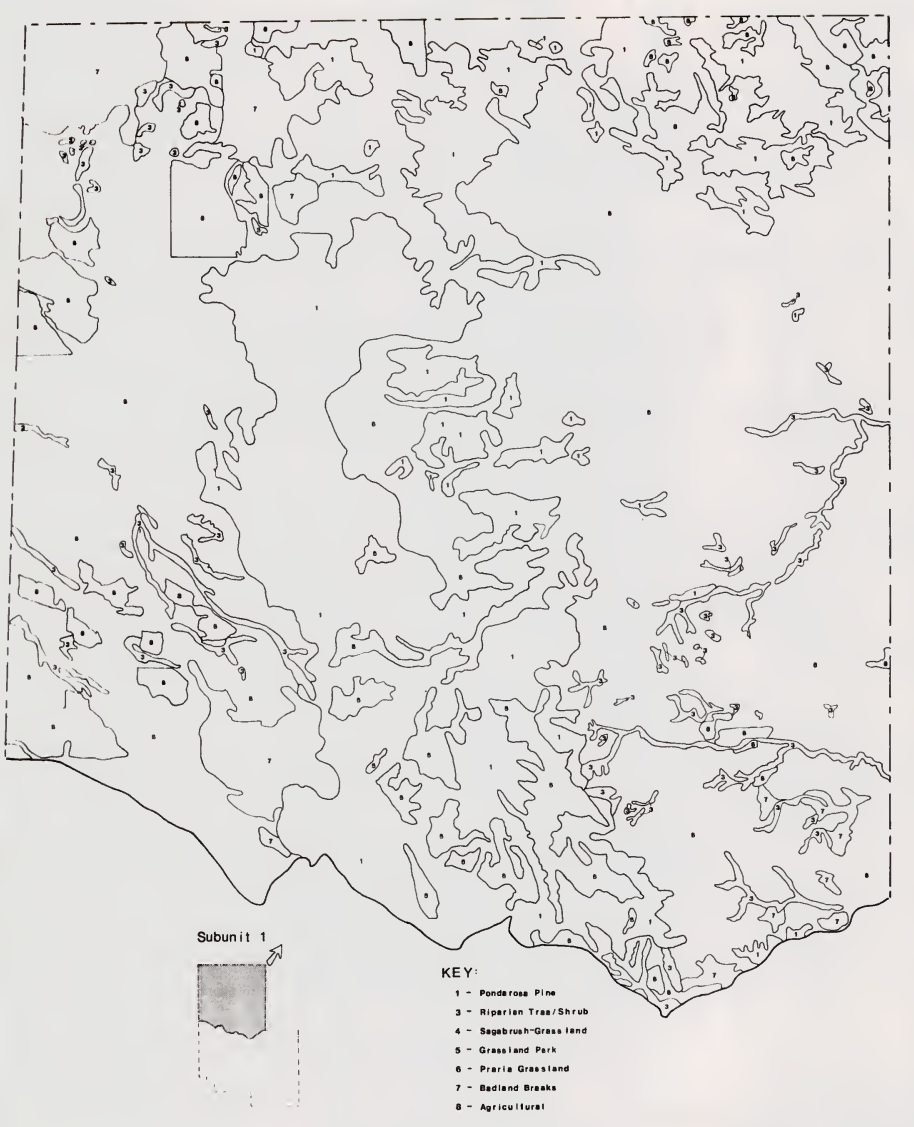

Appendix Figure 2. Distribution of vegetational cover in the Long Pines study area from infrared aerial photographs. 


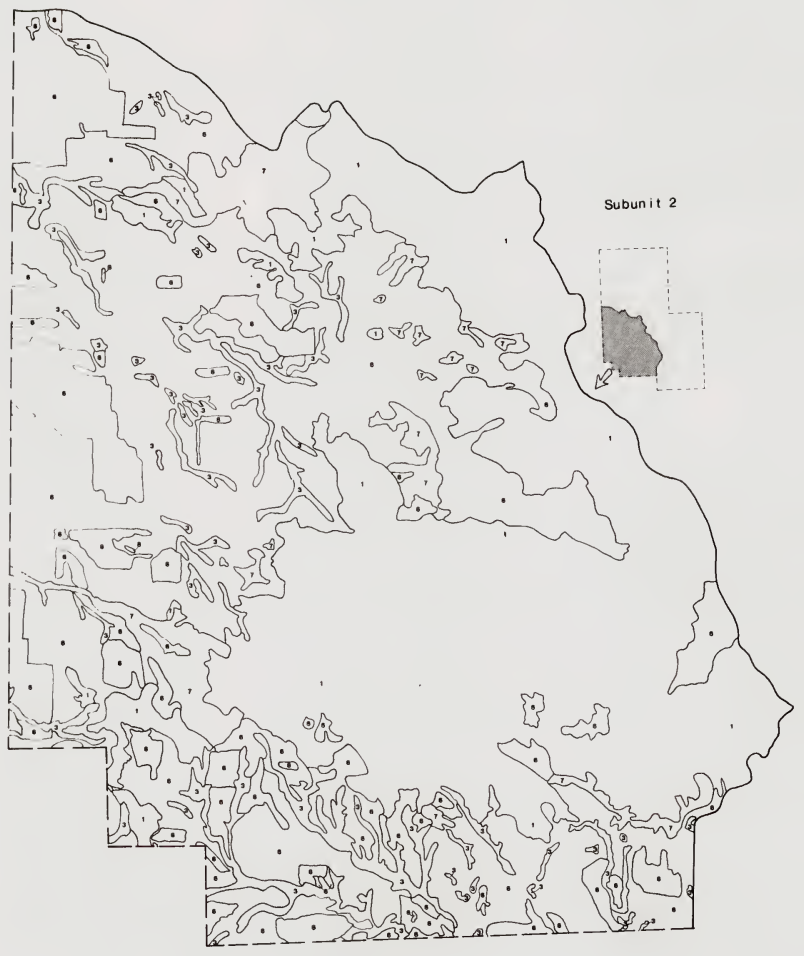

Appendix Fiqure 2 (continued). 


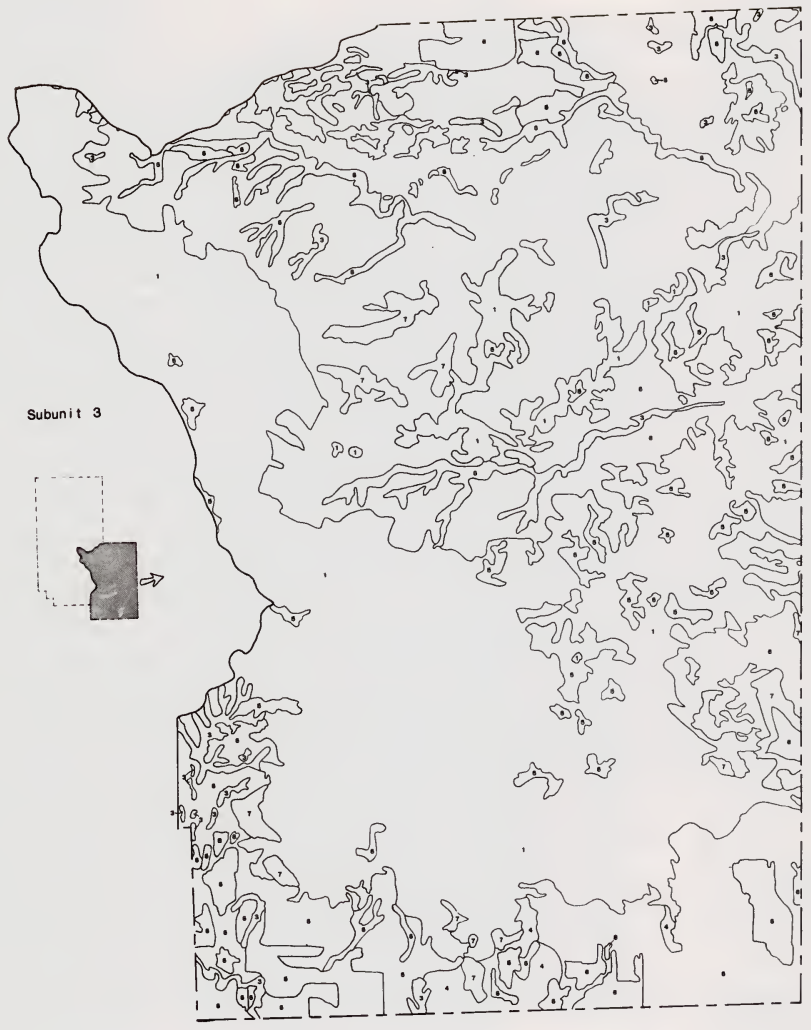

Appendix Fiqure 2 (continued). 


